\title{
THE FORMATION OF CANNING'S MINISTRY
}

\section{Robert Peel to Mrs. Canning.}

Whitehall. I7 February, $\frac{1}{2}$ past 2.-As I find that Sir William Knighton is in London detained here by illness, and that he thinks it may be of importance that some one should wait personally upon the King with the report of the physicians, I propose to come this evening to Brighton after I shall have seen the physicians who are to meet at Fife House at four o'clock.

I will call upon you tomorrow morning. As I am afraid that Canning is not well enough to see the King at present, it is perhaps more necessary that some one should wait upon his Majesty.

(Add. MS. 403II, ff. 244-5.)

\section{Robert Peel to the Duke of Wellington.}

Pavilion, Brighton. Sunday, twelve o'clock [I8 February].-I arrived soon after ten last night-found the King suffering much from gout in both feet-both knees and the left hand-in other respects well and not materially agitated, though greatly distressed by the afflicting account which he had previously received from me. He asked me what was the best course in my opinion to pursue-and seemed himself inclined to an adjournment of both Houses of Parliament for a few days. I advised him to determine nothing at that time, and told him that I would see Mr Canning in the morning (this morning) and and [sic] would afterwards wait upon his Majesty.

This morning I saw Mr Canning and found him very much better than I had expected. He has suffered very little if at all within the last two days from pain in the head. Mrs Canning on receiving my letter of yesterday at once apprized him of Lord Liverpool's attack.

The result of my conversation with $\mathrm{M}^{\mathrm{r}}$ Canning this morning was a decided impression on the minds of both of us, that we ought under present circumstances to take no proceeding which would notify to the public a despair of Lord Liverpool's recovery; that it was due to him, and most advisable on public grounds to 
consider him as the First Minister of the Crown, and that it would be better to proceed with the ordinary business of the House of Commons-(Army Estimates \&c. \&c.) particularly as the business standing for discussion next week is not of any peculiar importance.

Supposing Lord Liverpool to survive this attack but the physicians to decide positively that his retirement from public life is indispensable, it will be time enough some days hence to determine on the course to be pursued. Supposing the attack to terminate fatally-adjournment of the two Houses-and suspension of public business may then be necessary. Since I saw Mr Canning I have been with the King, who entirely acquiesces in the course which appeared to $\mathrm{Mr}$ Canning and to me the best under present circumstances. 1

I shall remain here until I receive the account which Sir Henry Halford is to dispatch about twelve o'clock today. If there be no very material variation in his report I shall return to London this evening.

(Add. MS. 38749 , ff. $81-2$.)

\section{Frederick John Robinson to William Huskisson.}

Downing Street. Sunday evening [I8 February].--Would it not be right that we should consider a little what ought to be done in the House of Commons tomorrow upon the subject of our business. Wynne and I will call on you in the morning about eleven, if it will suit you to receive us so early; and if Peel has returned from Brighton, I will beg him also to meet us. If upon talking the matter over, it should seem to be necessary to have more of a Cabinet upon it, we can get together by two or three o'clock. But the immediate points are more for us of the House of Commons. (Add. MS. $3^{8} 749$, f. 84 .)

\section{William Huskisson to Frederick John Robinson.}

Somerset Place. I8 February, $40 \mathrm{~m}$. past 6 p.m.-Your note was brought to me just as $\mathrm{Mr}^{\mathbf{r}}$ Backhouse, ${ }^{2}$ who left $\mathrm{Mr}$ Canning at Brighton, at one today, had called.

1 Professor Temperley states that these interviews took place on the rgth. (Foreign Policy of Canning, p. 4I7.)

2 John Backhouse was in charge of the consular department of the Foreign Office before 1827 ; in April 1827 he was appointed Permanent Under-Secretary for Foreign Affairs. 
He brought me no letter, but was desired to communicate to me confidentially that the King, though sorely tormented with the gout, was very calm; that Peel had been with Canning, and that they entirely agreed that all public business in the two Houses should be pressed forward in its ordinary course ; and that everything should proceed without interruption just as if Lord L[iverpoo]l was prevented from attending to business by any serious but not necessarily permanent illness; and that everything in short should be understood to go on upon that footing for the present. Peel saw the King again, after leaving $\mathrm{M}^{\mathrm{r}}$ Canning, and H.M. perfectly acquiesced in this course. Whether we shall be allowed to follow it, without objection, in the House of Commons, may be another question, but I do not think any objection will be taken so early as tomorrow. It would be in the highest degree precipitate and indelicate.

The Army Estimates and the other matters which stand for tomorrow should therefore proceed; and Canning fully intends to open the Corn question on the Monday following.

Notwithstanding this intelligence from Brighton, I think it will be highly desirable to have a meeting tomorrow morning; and I am sorry to put you to the inconvenience of coming here. The weather is so bad that I am almost afraid to venture out of this room.

Canning, I am glad to find, is gaining strength, and seems confident that he shall be fit for work on Monday the $26^{\text {th }}$.

[P.S.] Peel would wait at Brighton for this morning's report, and return to town tonight. ${ }^{1}$

(Add. MS. 38749 , ff. 86-9.)

\section{The Duke of Wellington to the Duke of Buckingham.}

London. I 8 February. (Copy.) - I have to apologize for having omitted to answer your letter of the $\mathrm{I}_{4}$ upon the receipt of it. ${ }^{2}$

1 Croker wrote to Lord Hertford on the rgth: "Peel is not come back, but will be in the House tonight. I believe that he, Canning and the King are all agreed, out of decency as well as policy, to take no step till Lord Liverpool is either better or worse : this sounds well, but it is a mere sound, for we know that they, and all the other parties, will take every step they can, and will endeavour to make good their respective views, tho' the final announcement: of the result may be delayed . . " (Croker MSS.)

2 See W..N.D., iii. 589. The Duke of Buckingham had threatened to withdraw his support from the Government because Liverpool had declined to recommend him for the Governor-Generalship of India. 


\section{THE FORMATION OF CANNING'S MINISTRY}

But I expected to see Lord Chandos; and I have had a good deal to do these last two days.

You will have heard of the misfortune which we have suffered in the person of Lord Liverpool, respecting whom it is to be apprehended that he will never recover. My business has always been to endeavour to prevent friends from differing, and to reconcile any differences that might occur; and I need not assure you that my best offices would have been exerted to put you \& Lord Liverpool on the best terms.

(Wellington MSS.)

\section{The Duke of Bedford to Lord Holland.}

Woburn Abbey. Sunday [I8 February].-... Who will be Prime Minister? Canning or the D. of Wellington? "When Greek meets Greek, \&c." Liverpool will be no loss. He was a goodnatured man in private life, but contemptible as a politician. His conduct in the Queen's business completely damned him in my estimation. Whatever changes may take place by the $\mathrm{D}$. of York's death or Liverpool's retirement, the Catholick question will never be carried but through fear, and I am convinced we are retarding the cause by giving in to, and becoming parties to, the juggle of Canning, Plunkett \& Co., and for this reason I regret to see the question brought forward by Lansdowne and Burdett. . . . (Holland House MSS.)

\section{The Duke of Wellington to Robert Peel.}

London. Ig February.-I thought it best to request Lord Bathurst to call together the whole of the Cabinet in town, and they assemble at Huskisson's at three. . . .

(Add. MS. 40306, f. 232.)

\section{Henry Goulburn to Robert Peel.}

Portman $S q[u a] r e$. I9 February.-...Quite private-If the Gov is to go on as it is, what say you to Canning's going to the House of Lords?

(Add. MS. 40332, f. 280.) 


\section{THE FORMATION OF CANNING'S MINISTRY}

\section{Frederick John Robinson to Robert Peel.}

Downing Street. Monday evening [I9 February]. Private.-I have heard from Huskisson the result of your consideration with Canning as to the course to be pursued in the House of Commons, and I believe that you have judged right in thinking that all things there should proceed in their natural course. . . .

(Add. MS. 40392, f. 39.)

\section{Io. William Huskisson to George Canning.}

Somerset Place. Ig February.-Backhouse arrived here between six and seven yesterday evening. About the same time Peel's messenger returned with a letter from him to the Duke of Wellington, making a report entirely corresponding with that of Backhouse of what had been agreed upon with you, and afterwards acceded to by the King. It was thought right to summon a Cabinet which was held here at three o'clock, as I am not allowed to go out in this detestable weather. There was no difficulty started by any one in respect to going on with all the ordinary current business which stands for this week ; and after some discussion and objections (principally from $\mathrm{W}$ [estmorlan]d), it was settled that if a question was asked about corn, the answer in our House should be that "you hoped and expected to be able to bring forward the subject on the day for which it now stands, and that, if well enough, it was your intention to do so." In respect to the House of Lords where Lauderdale is likely to be stirring, it was understood that the answer should be, that there certainly was no probability of Lord Liverpool being able to attend on Monday, and that notice would be given between this and Monday, in case it should be thought necessary that any other member of the Government should on that day call their Lordships' attention to the subject. It is clear that Bathurst will not undertake it; and upon the whole I incline to the opinion that it may be better upon the whole not to stir the question in the Lords till it has worked its way through our House. In saying this, I am fully aware of the great public advantage there would have been in the course which Liverpool had chalked out for himself; and I fear that his absence will be the cause of great additional difficulty, in settling this question either now or at any future time.

The conviction that poor Liverpool, if spared, can never take 
any further part in public life, is so universal and strong, and it is so unequivocally the language of all the medical men, that it is not to be assumed the House of Commons will allow business to proceed much longer without some explanation. That they will not, is the decided opinion of all who met here today, and of every person that I have seen. It is still possible (though not probable according to present appearances) that he may not survive the week; and on the other hand it is possible that he may be so far recovered as to be able to resign his office. These are the only two alternatives contemplated; and should either occur, it would certainly be the general feeling (it was that of the Cabinet) that corn could not be brought forward till there was a Prime Minister appointed. Indeed, I cannot suppose that, in either of these suppositions, it would be thought either just to the question, or discreet in the mover of it, to send it forth to the public, without knowing beforehand how it would be looked upon and supported by his colleague or colleagues, whoever they might be, in their own situations. ...

(Harewood MSS.)

\section{George Canning to Viscount Granville.}

Brighton. 20 February. Private and Confidential.-I received your demi-official letter last night, which I lost not a moment in laying before the King; and anticipating $\mathrm{H}$. M $\mathrm{M}^{\prime} \mathbf{s}$ permission, which you will receive by the present messenger. You will have learnt, however, under what very different circumstances this leave is granted, from those under which it was asked. The tremendous calamity which has befallen Liverpool must necessarily put off Corn and Catholicks in the House of Lords until the result is ascertained; and if that result should unhappily be fatal, until a new Administration shall be formed. I do not therefore wish to retract the leave, or that you should postpone your coming : quite the contrary-but I feel quite sure that in a season of such agitations and rumours, as we are to expect, during the interval, while the consequences of Liverpool's attack are uncertain, your bringing your whole family over, of which intention I was not aware till Seaford mentioned it to me last night, would be liable to a thousand misinterpretations, and expose you and myself to many unnecessary difficulties.

$$
\text { (P.R.O., G. \& D., 29/8.) }
$$




\section{THE FORMATION OF CANNING'S MINISTRY}

\section{I2. George Canning to William Huskisson.}

Brighton. 2I February, $\frac{1}{4}$ before 12.-Your letter of last night filled me with astonishment and dismay. After Peel and I had agreed to recommend to $\mathrm{H}$. $\mathrm{M}^{\mathrm{y}}$ and $\mathrm{H}$. $\mathrm{M}^{\mathrm{y}}$ had been graciously pleased to consent, that publick business should go on, as if nothing had happened, until either a positive event-or poor L[iverpool]'s recovery to a sufficient degree to tender his resignation-or clamour in Parlt (if there is any danger of that) should force us into another course, after, I say, Peel, the member of the Gov ${ }^{t}$ whose consent was the most important, and the most unlooked for, had agreed, and had laid it before the King and Cabinet, it does drive me mad to find this plan overthrown. The single solitary chance of an amicable arrangement of the Govt lies in a vote of the $\mathrm{H}$. of $\mathrm{C}$. on the Catholick question taking place while the Govt is in abeyance. Whichever way that vote turns the result would be an incalculable facility. By leaving Burdett's notice undisturbed in order to [do] which it was necessary to leave my notice for Monday undisturbed also, there was a chance of atchieving this object on Thursday next-a doubtful chance I admit-because it required that there should be no decisive change in Lord L[iverpool]'s [condition] for 7 (or rather for 9 days, from Monday, the day on which Peel and I settled this point). Now for no assignable reason the chances of four days more are added to these nine and with that the extreme probability that when Burdett puts off his motion, some less conscientious and honourable Protestant may see the great disadvantage to them of discussing the question with the Gov ${ }^{t}$ in abeyance, and may call upon Burdett to put it off till a new Govt is formed. To such a suggestion Burdett would gladly agree, as it is obviously the interest of the Whigs that the Cath. ques. should be debated among ourselves BEFORE it is debated in Parlt.

In short, if the dissolution of the Gov' precedes the discussion of the Cath. ques. all chance of amicable settlement is gone. This is what the Protestants must wish-this is what the Whigs must wish. By God's providence Burdett had, by fixing his motion, played our game; if he has been allowed to unfix it, that game is gone. In that case, I must have it understood by the King-by Peel and by Burdett, that $I$ am no party to the postponement. Peel would have a good right to take it ill, that I should have made him the proposer to the King, of a plan unpalatable to the King at the time, and now afterwards abandoned. Burdett must 
be apprized that the message which I sent by Lushington on Monday, to be delivered to any member of the Opposition, who might speak to him on the subject, that $I$ by all means advised against the postponement of the motion, and that $I$ should certainly be in the $H$. of $C$. both on Monday and Thursday, was a true message, and contained my real and unchanged opinion. As to Kensington's saying that he had not seen you, or as to his not having been sent direct for the purpose of seeing you, it is really idle to be taken in by such professions. He was sent directly for the purpose of obtaining your sanction to the postponement of Burdett's motion-such being (as I have said) plainly the interest of the Whigs-and I shall not be surprized if I find that Burdett has assigned your desire or mine as a reason for the postponement of his motion-if mine I implore you to set me right with Peel, and I will set myself right the first day that I come to the $\mathrm{H}$. of $\mathrm{C}$. That day will be Monday. No consideration on earth shall induce me not to be in my place on that day, ready to open the Corn question. There shall not be an hour's postponement on my account. I have no objection to a Cabinet on Sunday, if you think it necessary-but all that $I$ shall do at that Cabinet is to read Lord Liverpool's paper as affirmed by the individual votes of the last Corn Cabinet, and to say that it is the substance of that paper which I shall move as the organ of the Cabinet. You say there are some questions of detail not settled. Be it so-those questions of detail are not necessary on the first opening, on which we do not call for a vote. Let me implore you therefore not to play $\mathrm{L}^{\mathbf{d}}$ Westmorland's game also by not to mooting these unsettled points at the Cabinet, but to go wholly upon what is agreed, which is quite sufficient for the first day in the $\mathrm{H}$. of $\mathrm{C}$. [sic]. The consideration of the resolutions may be adjourned to any day you please : but it is, in my opinion, of vital importance to launch the Corn question under the shadow of Liverpool's authority though in abeyance-and if you give up that advantage to Westmorland, as I am afraid the advantages of the Cath. $Q$. will have been given up to the Tories and the Whigs, you will have stripped me of the only two facilities through which I saw any hope of getting through the difficulties of the crisis consequent upon Lord Liverpool's failure.

What I am to say to the $\mathrm{K}$. whom I am to see today or tomorrow, and to whom I should naturally have talked in the same sense as Peel, I am utterly at a loss to conceive. 


\section{THE FORMATION OF CANNING'S MINISTRY 9}

I conclude with saying that nothing shall induce me to consent to Corn being postponed on my account.

PS.-I implore you never to trust Kensington in anything in which I am concerned.

PPS.-One faint chance of salvation strikes me ; even if Burdett has put off his motion till the $5^{\text {th }}$, may he not be persuaded to bring it back again to the $\mathrm{I}^{\text {st }}$ ?

PPPS.-Perhaps the King may fix tomorrow for seeing me. If so you may possibly relieve my fears before I go to him.

(Add. MS. 38749, ff. 95-IOo.)

\section{George Canning to William Huskisson.}

Brighton. 2I February.-Backhouse is this moment arrived; comparing his explanation with your letter which $\mathrm{I}$ have given him to read, I conclude I must have attached too strong a meaning to the two passages in your letter " that Burdett will postpone till the $5^{\text {th }}$ of March" ; and "it is possible that Burdett may postpone his notice in the course of this evening." From these passages I certainly inferred that the postponement was determined upon. My only doubt was when it was to be announced. I now find from Backhouse that no announcement of it has been or is likely to be made, and I am therefore sorry that I expressed myself as warmly as I did, under the idea of the mischief that such a change would have produced. Undoubtedly it would have been the greatest personal convenience to myself to have had the additional four days from Monday to Thursday, but that convenience would be dearly purchased by four days additional risk of such a termination of the uncertainty of Lord Liverpool's state as would prevent the Cath. ques. from being discussed before the formation of a new Government.

PS.-I am grieved to hear from Backhouse that you are still so poorly. . . Possibly we might without incurring any inconvenience, jog on from Monday to Tuesday, in which case we might have the Cabinet on Monday instead of Sunday. I am to see the King tomorrow.

(Add. MS. 38749 , ff. I02-3.)

\section{I4. Sir Robert Wilson to Earl Grey.}

2I February.-Wynne said yesterday to a friend of mine "that until the King was better and able to move to town, no proceedings 


\section{IO THE FORMATION OF CANNING'S MINISTRY}

could be taken in the formation of a new Ministry - that it was also wished to delay that a chance might be given Lord $\mathrm{L}$ [iverpoo]l to resign. . . " There are an infinite number of speculations afioat, but Canning's friends feel confident that either he will be Premier of a concordant Cabinet or that there will be a total break up and new combination. This opinion is also that of the chief portion of the advy Party ...

(Add. MS. 30124, ff. 252-3.)

\section{The Duke of Buckingham to the Duke of Wellington.}

Stowe. 2I February. Secret \& confidential.-I feel extremely gratified by my son's account of the reception which you were good enough to give him, and by your general expressions of kindness towards me. I have no difficulty in saying that I leave the whole affair in your hands, in perfect reliance on your real wishes to serve me, and from no one would I receive a favour with the pleasure which the receiving it from you would give me. Now allow me to open myself to you, and to bribe you to let me do so, at this moment of intense anxiety and business, I begin by saying that I require no answer. But still read my letter.

I begin by supposing poor Lord Liverpool politically dead, however he may be a little better or a little worse as to bodily health. I therefore consider his Administration to be broken up, and whatever be the change, be it great or small, of one man or more, it is a new Government. I once held a conversation with you in which you detailed to me your views of the Catholic question, and the mode in which alone you thought it could be settled advantageously for the Empire. I agreed in your views then, and I equally do so now. I know not whether you have changed them since. I think not, because " the black \& dense cloud gradually approaching us" which you contemplated with fear then, has certainly not paused in its course, or diminished the intensity of its colour or threatening demeanour since. The opportunity is come for your setting this great question at rest. The situations which you fill preclude your being First Lord of the Treasury, but put another there to fulfill your views-your brother from Ireland for instance, \& send me there in his place. But let who may be in Ireland or who may be Minister ostensibly, on you let the task fall of setting the Empire at peace at home, as you have maintained her greatness abroad. You would rally the Tory party round you, which would place 


\section{THE FORMATION OF CANNING'S MINISTRY}

confidence in you, believing that you would not sacrifice the interests of the Protestant Establishment unnecessarily, and to the moderate party supporting the Catholics, $\mathrm{Mr}^{\mathrm{r}}$ Canning continuing to act in the Government, your brother, and myself would serve as pledges that the Catholic question would be to be set at rest. The King too would not probably be ill pleased to see a question set at rest in his time, which otherwise he may think will not be so advantageously settled in the days of his successor. Upon that latter question, it is in my power to give you much information. Now pray think this over. No other result that I see, can give us a stable Government. No one will be content with the new First Lord let him be who he may, in Lord Liverpool's place, in any other view of the question. The fulcrum upon which the balanced Administration moved is now gone-you cannot restore it. The Catholic question must and will be carried. Is it not better to take the measure into your own hands, and do it as it ought to be done, than to let it be done by others in a way you will not like? $\mathrm{M}^{\mathrm{r}}$ Canning will not do. Every one is proud of his talents, but no one trusts his principles. He will carry the question, and then turn round upon those who assist him, and turn the details to his own objects. Believe me I have reasons for what I say. Now if I can, on these terms, assist your views, I am at your service. The question being so arranged, I can bring you ten or eleven votes in the $\mathrm{H}^{\mathrm{e}}$ of Commons at least who will follow me, and I will help you in Ireland, if your brother comes away in consequence of the new arrangements. If not, send me to India, and before I return, the question will have carried itself in spite of you. I have written most unreservedly to you. I need not impress upon you secrecy but assure yourself that this letter is written by one grateful to you for your kindness, and anxious to prove himself so.

(Wellington MSS.)

\section{I6. Sir James Mackintosh to Lady Holland.}

Ampthill Park. 2I February.- . . I see only one good arrangement-Robinson succeeding $L^{d} L$ iverpool] with a peerage \& Husk[isson] being Chancellor of the Exchequer. Peele's being Prime Minister is so bad that I suppose Canning could not continue in office, \& Canning's being First Lord with a peerage would be a surrender of the House of Commons with Ireland \& the Continent to Peele. . . .

(Holland House MSS.) 
17. The Duke of Wellington to the Duke of Buckingham.

London. 22 February. (Copy.)-I have received your letter and am much gratified by the confidence you are disposed to repose in me. I am afraid however you are mistaken respecting my power either to effect the publick objects upon which you write or to forward your views. In fact, nobody has spoken to me on the subject of the office of Govr General excepting one gentleman, a Director, who came to me to propose that my brother Sir Henry Wellesley should be appointed; to him I answered that I had nothing to say to the appointment and that he must go and settle who should be Govr General with those servts of the Crown whoseduty it was to discuss this selection with the Court of Directors. In respect to the Catholick question I have not alter'd my wishes. But I confess that I doubt more and more the chance of a settlement. Nor have I an idea of what will be the arrangement of the Gov' when Ld Liverpool's place will be declared vacant.

(Wellington MSS.)

\section{The Duke of Bedford to Lord Holland.}

Woburn Abbey. 22 February.-.. I know not how the negociations now going on, to form a new Cabinet, may end ; but I am willing to hope that something good may in the end turn up. I hear the City people wish for Lansdown, \& I am not surprized at this. . . . I am no politician, having done with politics some years; but I cannot help being an anxious spectator where the public good is deeply concerned. Canning may do good if his health is equal to the task; but he must throw the Chancellor \& the Bishops overboard, \& take the helm with a courageous determination to steer the vessel clear through the hidden rocks \& shoals. which surround it. ...

(Holland House MSS.)

\section{I9. William Huskisson to George Canning.}

Somerset Place. 22 February.-I have been so hurried and worn for these last three days, and my head becomes so confused at the close of business that I am not at all surprized at my letters con- 


\section{THE FORMATION OF CANNING'S MINISTRY}

veying a different meaning from what $I$ intended. As none of the mischief which you apprehended has occurred, it is not worth while now to revert to the subject. At any rate what I have further to say upon it will keep till we meet. But I must repeat, in justice to Kensington, that I am convinced he was not put forward by any cabal, and that if he had any other motive, beyond that of good nature, it was a wish to make himself of a little importance. 1

This morning, another friend, who is not altogether free from this latter feeling-Littleton-called upon me with the enclosed letter $^{2}$ to you, ready written. He came to ask my opinion, whether you would think him impertinent and officious if he sent it. As his communication neither requires an answer, nor gives an opinion, I told him that I did not think it open to this objection, and in consequence he left it in my hands to be forwarded. I have since heard the same report from Warrender, who quoted some of the same parties. The mischief of these declarations is the impression which they make on some of our own ultras. Otherwise it is well to know that the general tone in which even many of the ultras concur, is that the Government can only be kept together by your being at the head of it, or as Lord Hertford, I am told, expresses it, "Providence has placed it in his hands, and I trust it is all for the best, only we ought not to be pressed too hard at first on the Catholic question." Warrender was more decided in his statement than even Littleton in what he represented to be the language of the best part of the Opposition on this question. I mean, that there would be no reason to complain if, in the new Government, that question were for the present left upon the same footing as that on which it has hitherto stood. . . .

(Harewood MSS.)

1 Endorsement: "All this refers to the putting off of Burdett's motion from the $I^{\text {st }}$ to the $5^{\text {th }}$, which I desired might not be done on my account.-G.C."

2 Littleton to Canning, 22 February, giving an account of a Whig party meeting (E.H.R., April 1927, p. 202). Croker wrote to Lord Hertford on 17 March: ". . I I am afraid that the chances of keeping the Government together are less than I had hoped : the difficulties will not be of Canning's making. All that you heard of communication from Brookes, or to the Vice [sic], was unfounded-there has been no such thing!!! That is certain!" (Croker MSS.) 


\section{Henry Hobhouse's Diary.}

Thursday, 22 February.- . . . When this public calamity [Lord Liverpool's seizure] occurred, the King was at Brighton, whither he went the day after the D. of York's funeral, and was confined to his bed in an attack of gout. Canning, the Leader of the House of Commons, was also at Brighton, confined to his bed by intermittent rheumatism, and it was doubtful whether he was well enough to bear the communication of $L^{\mathrm{d}} \mathrm{L}^{\text {'s }}$ state. $\mathrm{M}^{\mathrm{r}}$ Huskisson, the President of the Board of Trade, was confined to his bed by illness in town. The other Ministers were at their posts, and in the course of the morning assembled at the Home Office, and agreed una voce that $\mathrm{M}^{\mathrm{r}}$ Peel $\mathrm{sh}^{\mathrm{d}}$ forthwith wait on the King at Brighton, $w^{\text {ch }}$ he accordingly did in the course of the evening. The King was much affected at the event, $w^{\text {ch }}$ forcibly reminded him of the loss he had sustained in the death of the D. of York, by $w^{\text {ch }}$ he was deprived of the only person with whom he cod $^{d}$ confidentially consult as to the formation of a new Ministry. In the course of his conversation he mentioned to $\mathrm{M}^{\mathrm{r}}$ Peel that the greatest loss he had ever sustained was in the death of $\mathrm{L}^{d}$ Londonderry. The King concurred with the Cabinet in thinking that no step shod be taken towards filling up $L^{d} L^{\prime}$ s office, until time had been allowed for the chance of his recovering sufficiently to become sensible of his own malady and to tender his resignation.

(Hadspen House MSS.)

\section{2r. George Canning to Robert Peel.}

Brighton. 22 February.-Sir F. Burdett has offered, through various channels, to postpone his motion to the $5^{\text {th }}$ if it would be any convenience to me. I have answered that I had no wish for any postponement-not doubting that I should be in my place in the House of Commons. I see, by what passed in the H. of Commons on Tuesday, that you have said the same thing for me. If Burdett postpones, therefore, it is for some convenience of his own. Should he do so, and thus leave Thursday vacant, it would certainly be no inconvenience to $m e$ to have Corn postponed to that dayand I find that it would be a convenience to Huskisson who is more unwell than I had imagined. But I would on no account have the postponement suggested, or thought of, unless Burdett of his own head makes the vacancy on Thursday. Perhaps, without 
much difficulty, we might jog Corn from Monday to Tuesday (without any reference to Burdett's motion) which would give us an opportunity of a Cabinet on Monday-and allow me the choice (according to weather) of Saturday, or Sunday for my journey to town. But I would not wish this, unless it could be done without effort. I am to see the King today. I do not hear that Sir Wm Knighton is yet come down.

(Add. MS. $3^{8} 749$, ff. II6-r7.)

\section{Robert Peel to William Huskisson.}

Whitehall. 23 February. - I received the enclosed [No. 2I] last night in the House of Commons from Canning. I confess I had a strong impression that it would be much better on the score of health both for him and you, that Corn should come on on Thursday instead of Monday. Without actually suggesting delay to Sir Francis Burdett I have with the aid of Abercromby so arranged that Catholic question shall stand for the $5^{\text {th }}$ March, and Corn be jogged on as Canning says, from Monday next to Thursday next.

$$
\text { (Add. MS. } 38749 \text {, f. II2.) }
$$

\section{William Huskisson to Robert Peel.}

S[omerset] P[lace]. 23 February. (Copy.)-Two days ago Canning was so adverse to any delay beyond Monday for Corn, and so much annoyed at my having suggested to him the postponement till Thursday (of the practicability of which as far as Burdett was concerned, I had been assured) that I felt it necessary to make known to all that asked me any questions, that Corn would certainly come on upon Monday. I have no doubt that Burdett, as a matter of accommodation, will consent to take the $5^{\text {th }}$ for his motion: but he will not do so of his own accord, which is what C [anning] seemed to expect when he wrote to you yesterday. If Burdett should not open the $I^{\text {st }}$ to Corn, the middle course suggested of taking Tuesday instead of Monday, may be something gained for Canning's other arrangements.

(Add. MS. 38749 , f. 118.) 


\section{William Huskisson to George Canning.}

Somerset Place. 23 February. (Copy).--Howard ${ }^{1}$ called upon me yesterday evening about seven, which made me close my letter to you without noticing your suggestion of jogging on Corn for one day, from Monday till Tuesday. The omission however is now immaterial. Early this morning Peel sent me your letter to him on the same subject, with a letter from himself stating what he had done in consequence in the House last night. I inclose his letter and a copy of my answer.

Between two and three, Kensington called in consequence of Burdett having put into his hands the note which he had received from Abercrombie. I took a copy of it which I also inclose. Burdett, who had been told the day before that Corn would certainly come on [on] Monday, and that there was therefore no reason for putting off Catholics beyond Thursday, had now only to say that he would do whatever was most convenient, it being understood that the $5^{\text {th }}$ was positively the latest day to which he could defer the C.Q. There was no time to lose, or for reference, before giving an answer. Peel, it appeared to me, had gone further than you intended; but I thought it would be very awkward to appear at all at variance with the language which it was clear he had held to Abercrombie, and that to decline the proposed accommodation might possibly leur donner à penser; and thereby lead to the very mischief which you wish to parry. I therefore confined myself to the requesting of $K$ [ensington] to make my best acknowledgments to Burdett for his attention, and to say that in the event of his taking the $5^{\text {th }} \mathrm{I}$ should certainly feel myself bound, in common with $\mathrm{P}$ [eel] and $\mathrm{R}$ [obinson] to ensure him that day for C.Q. whether Corn had been previously brought forward or not, and that I was confident you would ratify that engagement. So far, therefore, everything in my power has been done to prevent a delay more than from from [sic] the $I^{\text {st }}$ to the $5^{\text {th }}$ in bringing forward the C[atholic] $\mathrm{q}$ [uestion]. The first condition in the PS. to your note of this morning was placed out of reach before I received it. The $2^{d}$ is made as secure as it can be, and Burdett, I believe, will not swerve from it, unless the Catholic managers in Ireland should call upon him to postpone the question for the present. That such a change may take place in their councils, I think, is far from impossible,

${ }^{1}$ Lord Howard de Walden, Under-Secretary for Foreign Affairs. His father, Lord Seaford, was Canning's intimate friend. 
and even that it may be suggested to them from hence; but then $B$ [urdett] would equally have received his new instructions before next Thursday, and in that case would equally have put off his motion. Without such instructions, I am persuaded, B[urdett] will hold himself bound to go forward, that he is pledged to do so by the $5^{\text {th }}$ at the latest, and that no attempt to divert him from it, originating on this side the water, will be successful.

Your third condition is one over which we can exercise no controul, but I do not think the event likely to occur so soon as the $5^{\text {th }} \ldots$

(Add. MS. 38749 , ff. 120-22.)

\section{George Canning to William Huskisson.}

Brighton. 23 February.-Many thanks for your letter of yesterday, although it vexes me to think how much my worry and alarm must have encreased and exasperated your perplexities of body and mind. Instead of sending me back my letter (to be copied) pray put it into the fire. I write to Peel, to jog corn on from Monday to Tuesday, if he can. I should like to have it in my power to decide upon delaying my journey from tomorrow till Sunday (not that I should do so, if the day is tolerably favourable) or I should like to have Sunday to myself in town-or to myself and you, if you could come to me-and Monday for Cabinet, if necessary.

By the accounts which I receive this morning of Liverpool all immediate danger is gone by.

PS.-You did very right in sending me Littleton's letter.

PPS. - I should have no objection to Thursday for Corn-provided It $^{\text {st }}$ that the postponement was not on my account.

2 that Burdett would certainly bring his motion on, on Thursday.

3 that L[iverpool] would not resign between Thursday and Monday. ...

$$
\text { (Add. MS. } 38749 \text {, ff. r26-8.) }
$$

\section{George Canning to William Huskisson.}

Brighton. Frid. eq, 23 February.-Peel's letter, which I have just received, gives me two days more here-which is a great comfort, though somewhat alloyed by the dread of any event by which Catholicks may be put off altogether. . . .

(Add. MS. 38749 , f. 129.) 


\section{George Canning to Robert Peel.}

Brighton. 23 February. Private \& Confidential.-[Giving an account of his audience on the 22nd, and informing him that the King was satisfied with their joint advice.] . . . We had then a long talk of near a couple of hours, during which his Majesty went through a variety of subjects, but did not revert at all to the state of the Governmt till I was taking leave. He then said that he feared there were great difficulties. I answered that undoubtedly there were difficulties, but implored H.M ${ }^{y}$ to adhere to his resolution of not going to meet them by stirring any question prematurely. H.My promised that he would adhere to that resolution.

I thought you would like to hear how much the King's disquietude has subsided since you left him. It must have done so, very much from his Majesty's own reflection, as I believe he has been quite alone. He talked of writing to the $\mathrm{D}$. of W[ellington] to come to see him, which (as before) I encouraged. If you like to communicate what I have written to you to the D., pray do so.

ro a.m.- I this moment receive accounts of $\mathrm{L}^{\mathrm{d}}$ Liverpool, in the highest degree satisfactory and encouraging. I receive also a letter from Lushington, by which I find that the Speaker's health occasioned the breaking up of the House yesterday evening. From that, and from what passed about the Chancery Bill, I conceive a hope that I may gain 24 hours for corn, by a postponement till Tuesdaypushing Chancery over till some other day. If this can be done, they will be a precious 24 hours to me, if $I$ can know it in time to put off my journey tomorrow. But I am ready. 1

(Add. MS. 403I I, ff. 249-52.)

\section{George Canning to Robert Peel.}

Brighton. Friday night, 23 February. Private.-Many thanks for your kind letter of this morning. I went out today, to prepare myself for my journey tomorrow: but it is a great relief to me to be able to stay here a day or two longer-the rather as the bitterness of the east wind appears to be past. I intend to be in town on Monday. I congratulate you on the reception which your new amendments of the Criminal Law have met with from all sides of the House.

(Add. MS. 403II, ff. 253-4.)

1 A portion of this letter is in Parker's Peel, i. 450. 


\section{Lord Howard de Walden to William Huskisson.}

F.O. 23 February, 6 p.m. Most private and confidential.-I learn from my father that Peel has misunderstood Mr C[anning]'s letter and that he only wished for the postponement of the Corn question till Tuesday if it could have been managed without inconvenience. He must now write to Peel!

$\mathrm{M}^{\mathrm{r}}$ Canning is most anxious (although he has only just expressed his anxiety thro' my father) that no friend of his $\mathrm{sh}^{d}$ talk of his wishes, or in a way to imply that he had either considered or discussed any arrangement for carrying on the Govt. I therefore lose not a moment to letting you know this-and we must be very cautious how we talk of the present and future state of the Govt. He wishes (and the $K$. too) that it $\operatorname{sh}^{d}$ be considered that $L^{d}$ $\mathrm{L}$ [iverpool] may recover, and therefore until something is decided about his state-that things $\mathrm{sh}^{d}$ go on as they do now, and that [the] $K$. sh $^{d}$ take no step whatever for the present.

(Add. MS. 38749, ff. 124-5.)

\section{Joseph Planta to Stratford Canning.}

F.O. 23 February. Private.- . . . We have had a melancholy time of it here this winter. The weather, in the first place, has been dreadfully severe. Frost of unusual intensity, and east wind never ceasing, have cut us all up very much indeed. The Duke of York put us all in mourning in the beginning of January; and the events of H.R. $\mathrm{H}^{\mathrm{ss}}$ 's funeral, or rather the eventual effects, have been very distressing. One Bishop-he of Lincoln-died of it. Huskisson has never been well since-and our poor dear master (your cousin) has had an illness, arising chiefly out of the funeral, and partly out of a voyage of duty to Bath-which at first gave us. much alarm. It was a violent cold followed by a rheumatick ague - which fixed in the external parts of the head, and caused him to suffer torments. Brighton was the place of his confinement, $M^{r}$ Canning having lately bought a house there ${ }^{1}$; and from the end of January unto this day he has been there, for the most part in bed. He has been bled-and cupped, and cupped again, and dosed with calomel-put into vapour baths, and drenched with bark in its strongest form; and yet, notwithstanding all this, I

1 No. too Marine Parade, now the Royal Crescent Hotel. It was sold on 22 October 1827 for 4,000 guineas. 
hear from persons who saw him two days ago, that he has not lost much strength, or flesh, and that his spirits are very good. He comes up to town tomorrow: His spirits should be good, for while he was slowly recovering from his illness, came (last Saturday) the dreadful blow that deprived the Government of Lord Liverpool as a chief-and him of an attached and most useful friend in the management of affairs. Poor Lord Liverpool! I saw him on the Friday morning ; and I never saw him in higher force-or in a more comfortable state. He had been very ill some two months beforebut he had been to Bath since, and thought himself (and his friends thought him so) entirely recovered. In fact, I suppose he had filled himself too much at Bath-and was too well-and so came the stroke of apoplexy, which laid him without sense on the floor of his room while at breakfast. The papers will give you the particulars. I will only further say that I think it is most probable that Lord L's life will now be spared : though, as a publick man, he can hardly take part again. Thus then has the event which many people have, at different times, looked forward too [sic] happened at a moment when nobody expected it, and at one in which the two most important questions which divide the opinions of people in this country-Corn and Catholicks-are on the point of being discussed in Parliament. The line, then, which the remaining members of the Govt, particularly your cousin and $\mathrm{Mr}^{\mathbf{r}}$ Peel, have determined upon-and which has been sanctioned by the King, is, that no change whatever shall be thought of at present - that matters shall go on just as if Lord $L$. were attacked by an illness much less severe, and that the two great questions to be discussed shall come on as if nothing had occurred. Mr Canning conceives himself well enough to bring on Corn on Monday, and the Catholick question stands for Thursday; and till these are disposed of, and the further events of Lord Liverpool's illness are seen, no steps will be taken to fill up his situation. The Opposition seem to acquiesce in this course of proceeding. Since writing the above, I recollect that it is just possible that the questions may be both adjourned for a few days-but, anyhow, the Catholick $\mathrm{Q}^{\mathrm{n}}$ is not to be later than the $5^{\text {th }}$ of March.

On the event of that question will the course to be taken for the continuance of the Gov' or the formation of a new one, very much depend. A large majority for the question would probably lead to the formation of a new Govt_ of which your cousin would be the head and framer. A majority the other way would probably 
lead to the continuance of the present Govt-perhaps with your cousin, or with a friend of his, at the head, but without such decided influence being in his (G.C.'s) hands. A small majority either way would much embarrass all Parties. The only two things which can in my opinion drive your cousin (which for the sake of the country, and for all our sakes, God forbid!) from the Govt are-the coming in of the Opposition-toute pure-which seems quite out of the question-or the formation of an ultra-antiCatholick Government-which appears almost as impossible. There is to be sure $M^{\mathbf{r}}$ Peel-who will be a tower of strength wherever he is, but then he stands alone. There literally is not a second man, the Chancellor being all but about to go, to give him effectual assistance-and as to the rising generation - there appears to be hardly one amongst them, who does not think differently from him on this one subject of the Catholicks.

Thus, my dear Stratford, have I given you the carte du pays, and you can, from it, judge nearly as well as I can, what is likely to happen. My earnest hope is that I shall have, in my next letter, to announce to you, that your cousin is, as he ought to be, at the head of affairs. How I shall rejoice to see the country governed by him for many years, and you, my dear Stratford, coming home to assist and support him in his labours!

The King has been suffering from gout since his arrival at Brighton : but the fit, I understand, is a wholesome one, and it was wanted to set him in some degree to rights. I just learn that yesterday your cousin had a very satisfactory interview with his Majesty.

Now as to yourself. I have never lost sight of your views ; and have never omitted to avail myself of a favourable opportunity to allude to them, or to bring them forward. They have always been well received, and I have always looked to the summer as the time of accomplishing them. The instructions which you now receive will probably enable you to make progress in your Greek negotiation. Most important would it be for you to make some settlement of that question-if such a thing be feasible. That you might probably do in the spring, or the early part of the summer; and then return home in the summer or autumn-thisif you are not called upon by your cousin to return before. As to my little self, if things remain at all as they are, I suppose I shall go to the Treasury in July next.

$$
\text { (P.R.O., F.O. 352/16.) }
$$




\section{Lord Binning to Sir Charles Bagot.}

London. 23 February. - . . Nothing as you may well imagine is settled-\& I fancy nothing will be settled until poor Lord Liverpool shall have recover'd enough to send his own resignation-or until his family send it in for him. Further I do not believe anything will be settled till after Thursday next, the night on which the Catholic question is to be brought on. It is an immense advantage that the House should declare itself on that matter in the present state of things. If the resolution be carried by a good majority--surely it strengthens the hands of the Catholic part of the Government-makes Canning's absolute ascendancy a matter of course- $\&$ offers facilities of which he will not fail to avail himself for putting that great question in a train of speedy \& satisfactory settlement. If on the contrary-after the severe blows the Protestants have received by the death of the Duke of York \& the prostration of Lord Liverpool they should succeed in defeating us-such an indication will have been afforded of the invincible obstinacy of Bull as to render any arrangements that are to be made for carrying on the Government easier than they could have been-had it been necessary at the present moment to have press'd them forward. The time thus gained is very valuable in other respects. It gives opportunity for finding out men's leanings $\&$ opinions- $\&$ every step being coolly $\&$ deliberately taken is less likely to be a false step.

Everybody's temper seems to be good. As thus-I have just seen Howard 1 who returned last night from Brighton. He says nothing can be better than the temper of mind of Canning. He is resolv'd to make no unnecessary difficulties \& to facilitate arrangements as much as he can or ought. His feelings towards Peel are of the kindest sort, as Peel's are towards him. Peel went to him before he saw the King. I understand Robinson to have made very friendly declarations. With respect to the ould rubbish i'th' Lords, I know little. Indeed, if I had heard of the state de velours of Eldon I should mightily distrust it. I believe the Duke of Wellington's proceedings have been perfectly fair \& honourable. I do suppose that he will be content with that he hath. If he consults (as he seems to be doing) his own honour \& interest-he will aim at nothing of a different kind.

The temper of the Whigs seems to be good also and (strange to 1 Lord Howard de Walden. 
say of them at such a juncture) they seem to understand their own interest. There was a meeting of a number among them the other night-at wh. Brougham, Lord John Russell \& Abercrombie were present and all spoke. ${ }^{1}$ The determination was that it was not their business to throw any difficulties in Canning's way. That provided he were the undoubted Lord of the Ascendant they ought to remain satisfied--even though from the force of circumstances he might be compell'd to acquiesce in a Cabinet still divided on the great question-\& that they would not make that a source of vexation \& faction. This is most important-provided the meeting were such as to pledge the Whigs-for had they come to a contrary resolution they might have made it a very difficult matter to frame perhaps the only Government that can be fram'd at this moment-besides throwing Ireland into a civil war.

Persons who have been as long attach'd to a man as I have been to Canning ought in my opinion to avoid promiscuous talking on such occasions. I have abstain'd therefore as much as possible. Had I acted differently I might have had more gossip about men \& things to have sent to you-but I could have done no more. As far however as I can judge I imagine that most men anticipate Canning's being at the head. I suspect the very ultras-at least the most reasonable among them-to be quietly coming into the conviction that such is the best result even for them, under existing circumstances. A good majority in favour of Burdett's Resolution will help to fix them in that persuasion. I know some of great importance among them have held that language. The two principal speculations are-Canning avowedly head over all-with Robinson sent to lead the Lords - \& then in the event of Canning's clinging (wh. he will in any event be much dispos'd to do) to the F. Office ${ }^{2}$-Robinson to be First Lord--\& Huskisson Chancellor of the Exchequer.

\section{$2^{\mathrm{d}}$ speculation.}

Robinson to be a peer-First Minister \& First Lord-Huskisson Chancellor of the Exchequer. Other things as they are. This is founded on the notion that in the existing state of matters in the Cabinet there would be as great a difficulty in making some consent to serve under Canning - as it would be to make him serve under them-\& that this is your only safe compromise. This might be

1 See No. 19.

${ }^{2}$ Not until I 885 was there a precedent for the combination of the offices of First Lord of the Treasury and Foreign Secretary. 


\section{THE FORMATION OF CANNING'S MINISTRY}

consider'd as a patching up pro tempore-\& indeed it would not have anything very solid in it. Some who speak of this (wh. is a very common speculation) seem to think that Peel \& the Duke of Well ${ }^{n}$ would object to Canning's being Premier-the former on the ground of the Cath. question. This is perhaps a gratuitous assumption but whether it be or not, there cannot be the same difficulty on the part of Peel to serve under Canning that there must be on the part of Canning to serve under a Protestant Premier. To be sure, Robinson's elevation to the post of First Minister would not offer that difficulty, he being a steady Catholic $-\&$ the very circumstance of his being so elevated would give the universal impression that Canning was Viceroy over him. But this is by no means a good sort of impression for the country to have about its Governt, and offers an objection to the plan. I ought to have added to the first speculation that in the event of Canning's being First Minister \& First Lord \& Chancellor of the Exchr, Robinson still goes to the Lords as Foreign Secretary. There is of course the obvious plan of a thorough [illegible] Cath. Government-with the Whigs forming a part-but on this I think hardly anybody speculates. ...

(Bagot MSS.)

\section{William Huskisson to George Canning.}

Somerset Place. 25 February.-I heard from various quarters, in the course of yesterday, that during the last week there has been much discussion and division of opinion at Lansdowne House, whether the Catholic question ought not to be put off for the present. These differences among themselves took place before the postponement from Thursday, and they still continue. Burdett, I am told, is decidedly for going on. Spring Rice and others are of the same opinion. But Macdonald, and, I believe, Lord Lansdowne himself, are for delay. They contend that the question ought not to come on if the Government remains in its present state, and though they would have preferred putting it off at once, sine die, on the assumption that such was likely to be the case, they agreed to the postponement till Monday, as affording a chance that some arrangement might be made; and at any rate as affording further time for consideration. Part of this information I received from Binning who had it from Spring Rice. I found also that Wynn had heard the same thing both from Rice 


\section{THE FORMATION OF CANNING'S MINISTRY}

and Nugent. The remainder was told me by W. Lamb. He represented them as having been for the last four or five days quite at sea, and not at all able to make up their minds. Their confidence of a majority was a good deal shaken; they had lost four friends (two from Ipswich ${ }^{1}$ and two from Ilchester ${ }^{2}$ ) within the week, and four no Popery members had come in, in their stead. I understood Lamb to say that most of them were inclined to do whatever you might think best; but that Burdett was for going on, unless their friends in Ireland should be against it. I think it most likely that through Plunket, who arrived yesterday, or some other channel, you will be applied to for your advice or opinion very soon after you come to town. So far as I was concerned, I told Lamb that the question came upon me by surprise, and that I must decline giving either, but I begged him to consider that it was a very different thing to drop the question after notice, and after a call had been ordered, and to decline bringing it on now, supposing no notice to have been given; that it had always gained by discussion in the House of Commons; that a discussion, under the like circumstances as those which existed at all the discussions in the late Parliament, if terminating by a favourable. division, would have a great effect upon the public mind in England ; and that to drop the question at this crisis, would be open to various constructions, none of which, as far as it struck me at the moment, were likely to promote its success hereafter. I thought it right so far to let Lamb see that the leaning of my mind was in favour of going on. He said that he entirely agreed, and that he from the first maintained the same view, to which he was glad to see that my mind was inclined. I repeated again that I offered no advice or opinion; that I was not entitled to give any; but as to a private friend I had no objection to his so far letting him understand the impression which the first consideration of what he had stated had made upon my mind. I don't know whether I did right, but at any rate it is best that you should know what I have done, and what has been going on for some days. Plunket, I understand, is most desponding and gloomy.

(Harewood MSS.)

1 William Haldimand and Robert Torrens were elected on I7 June 1826 , but the House of Commons amended the return on 23 February by substituting two anti-Catholics, Charles MacKinnon and Robert Adam Dundas.

2 As the result of another election petition, the House of Commons on 22 February substituted Lionel Talmash and Felix Thomas Talmash for Richard Sharp and John Williams as members for Ilchester. 


\section{George Canning to William Huskisson.}

Brighton. 25 February. Private.-I have thought it upon the whole more advisable to take advantage of the additional respite, to stay another day, and take another airing here, before I undertake the journey to town. I shall therefore not set out till Tuesday. . . . If Burdett does bring on the C.Q. on the $5^{\text {th }} I$ shall not regret the postponement, for I should have been but barely equal to the discharge of my duty in the $\mathrm{H}$. of $\mathrm{C}$. tomorrow. But $I$ live in dread of another decision.

[PS.] The $\mathbf{K}$. is well-calm-and content to be quiet.

(Add. MS. 38749 , ff. I3I-2.)

\section{George Canning to William Huskisson.}

Brighton. Sunday night, 25 February. - I am not at all surprized at the project attributed to some of the Opposition, to put off the C. q. If they do so, in my opinion they put it off sine die. The only chance of a favourable result is in the declaration of opinion of the new House of Commons. I am sanguine as [to] the vote of Monday-if the question comes on. But I admit my sanguineness is founded on no very accurate data. I am not without hopes of an improvement in the House of Lords, if the new House of Commons declares itself favourably, and if the effect of that declaration has time allowed for it to work. But it is not reasonably to be expected that the Peers will change their votes, without some decent time for saving appearances. And if there is any hesitation shown in bringing the $\mathbf{H}$. of Commons to the test, all the considerations which are now influencing the Peers, and preparing them for a change, will turn the other way, and lead them to a sturdy resistance. I cannot conceive any more advantageous circumstances than those under which the $\mathrm{H}$. of $\mathrm{C}$. would come to its vote next Monday-more advantageous I think then than with a Govn ${ }^{t}$ declared in favour of the question. I am morally certain that an attempt to force the question upon this country by a Govnt united on this point, and for this purpose, would be the prelude to another catastrophe like that of the India Bill of I784 [i.e. I783]. The question must not force its way. ${ }^{1}$

(Add. MSS. 38749, ff. I33-5.)

i Part of this letter is paraphrased in Stapleton, iii. 304. 


\section{George Canning to William Huskisson.}

Brighton. 26 February.-Backhouse will call upon you with my amended speech to get from you a few dates-which are still wanting. I shall be in town tomorrow-probably by 6 o'clock. I hardly suppose that you would be able to dine with us. But I almost doubt whether I shall myself be equal to dining, after my journey. I am weaker than I apprehended, though essentially well. ... .

$$
\text { (Add. MS. } 38749 \text {, f. } 137 \text {.) }
$$

\section{The Duke of Buckingham to Earl Bathurst.}

Stowe. 26 February.-As the accounts which reach me induce me to believe that it his Majesty's intention to confer upon you the office of First Lord of the Treasury, I beg leave, under the circumstances which have come to my knowledge, which induce me to believe that the subject will be immediately pressed upon your attention, to offer my services to succeed Lord Amherst as Governor General of India. Last year when there was a rumour that Lord Amherst was likely to return, I made a similar offer, and I received from his Majesty's Government assurances that, were the peninsula of India at peace, I had no competitor.: The peninsula being now in that state, I trust that I shall have the good wishes and assistance of his Majesty's Ministers now, which were promised me last year, in the contingency of peace being restored. I send this letter unsealed by my son, who will have the honor of delivering it, and of explaining to your Lordship the circumstances under which I now put forward my claims, and the footing on which I stood as with respect to the Government now put an end to by the lamented illness of Lord Liverpool. Should your Lordship and his Majesty's Ministers wish that the same connexion of mutual support should exist which united me with the late Government, I request that your Lordship will be so good as to permit Lord Chandos to converse with you upon the subject, and it will gratify me much on private as well as on public grounds if the result shall prove satisfactory to us both.

(Bathurst MSS.) 


\section{James Abercromby to the Earl of Carlisle.}

6 New St. [February I827].-Burdett told me last night that the D. of Norfolk had expressed to him a wish that Morpeth should second the motion on the Cath. question. 1 Burdett wished me to communicate this to you, in order that you \& your son should form such decision as you think best. I have turned it in my mind, \& I feel doubts. Latterly this habit of seconding motions has been disused, \& on the whole I question whether it would not be as well for Morpeth to take his chance in the debate. It is clear that the Duke of $\mathrm{N}$. would wish a Howard to speak, \& Burdett is. perfectly ready to acquiesce if you wish it. From what I hear I have a very strong belief of two things. First that Canning is willing \& prepared to act a very low \& shabby part, being in his heart really eager for the Catholics but resolved to run no hazards. to save the country. Considering the state of Europe, the ground he has taken with respect to Portugal \& the condition of Ireland, it will be beyond even his skill to defend the honesty of the principle on which his Govt will be founded. It is in fact formed on a systematic exclusion of all honest principle. The next thing of which $I$ have a confident belief is, that $\mathrm{L}^{\mathrm{d}}$ Grey is quite prepared to expect: this result, to raise his standard for the purpose of doing all the damage he can to Canning, \& that his following will be nearly the whole of Opposition \& a large proportion of the liberal public.

[PS.] I think that even the most calm \& dispassionate must. allow that this is a case for enforcing principles of party. If you support for some purposes a Gov formed on so dishonest a principle, it is confounding all notions of right \& wrong in politics.

(Castle Howard MSS.)

\section{R. J. Wilmot Horton to William Huskisson.}

House of Commons. Friday night, [2 March]. Confidential.. . But what difficulties present themselves in the way of the re-formation of the Government! And what a tremendous opposition would at once be formed to a semi-Whig Govnt purely Catholic. At the same time other considerations present themselves, and I will disgorge myself of them, begging you to return me my letter (as I have no copy of it) as a record of opinion, which probably contemplates a course of proceeding very different from what will

1 He did so. 


\section{THE FORMATION OF CANNING'S MINISTRY}

take place. Can the present Government by possibility continue, or rather can they continue with credit to themselves, and advantage to the country, unless some mean (take the price of $60^{8}$ for wheat) be struck between the two extremes of unqualified concession and unqualified rejection of the Catholic claims?, and unless a real approximation be made towards one common centre, from the two extremes of the Tories, the excluding and admitting points. I should be disposed to answer that it could not and ought not to continue without such an approximation, but at the same time such an approximation does not appear to me to be POSSIBLE. Let us suppose Burdett's Resolution to be carried on Monday-it is the most probable supposition. Will the anti-Catholic members of the Cabinet consent to a repeal of those absurd and obsolete laws which make it treasonable to negotiate with the See of Rome? Will they consent to a negotiation (consequent to such repeal) upon the question of securities, reserving to themselves the most entire and uncompromised freedom of retaining in full their present objections to concession, unless such securities are offered as may reconcile them to the measure? On the other hand, will the Catholic members postpone any decision upon the question, until the termination of such negotiation, on the grounds that it is abstractedly expedient that negotiation with the Pope should precede any final settlement of the question? Can either party entertain a doubt that there is at this moment a considerable body of the Catholic gentry, who are desirous of withdrawing themselves from all connexion, real or implied, with the "Catholic Association," but who are afraid to do so, unless they had more than problematical security that such withdrawal would lead to an arrangement, by which justice might be done to the moderate and reasonable part of the Catholic body? To shew the extent to which this feeling really prevails among them, I know that at this moment there are a portion of the Catholic gentry, both English and Irish, who would consent to accept emancipation, coupled with a statutory enactment, that they should be for ever disqualified from voting in either House of Parliament upon any point deemed by such House to affect the rites, power, doctrine, and property of the Protestant Church as by law established. Any person who will read with attention the declaration of the Catholic Bishops, will perceive how easily an oath may be framed, very different from any hitherto devised, which will conclusively repudiate the imputation of their entertaining doctrines justly considered to be dangerous. I con- 
sider all attempt to pacify Ireland, or rather the Catholic Association, as HOPELESS. Even unqualified and unsecured concession would not avail. It must be a victory extorted, and not a boon conceded. But the greater, far the greater, part of the Catholics of character and property will be satisfied with measures far less summary and would accept them tomorrow-and, if they did not, and would not, I for one would separate myself from them, but I am more than convinced that they would. Suppose then that the question was stayed for the present year by the repeal of the Acts in question, and by negotiation with Rome. What are the alternatives which might arise from such negotiation?

I $^{\text {st }}$ Rome might be so unreasonable, she might protest against and disclaim (for example) the moderate tenets which are to be found in the late declaration of the Roman Catholic Bishops-and might thereby make it necessary for the Catholic part of the Govnt to refuse emancipation, unless the Irish Catholics were content to separate formally from Rome. Such a result would split the Catholics.

$2^{\text {dly }}$ Rome might be so reasonable, and consent to such satisfactory securities as to justify the anti-Catholics to withdraw their opposition from the measure. Such a result would also split the Catholics. $3^{\text {rd }}$ The course taken by Rome might appear to the Catholic part of the Govnt to afford every reasonable security, while the anti-Catholic part might entertain an opposite opinion. In this latter case, and only in this latter case, will the moment, in my opinion, arrive, when circumstances of overwhelming power must produce the dissolution of the old Tory Govnt, which has weathered the storms of nearly forty years with almost momentary exceptions. I consider the formation of a Coalition Whig Govnt in the present state of the public mind on the Catholic question, as hazardous. I consider the formation of a purely anti-Catholic Govnt as impracticable. I consider the maintenance of the present Govnt upon the principle of independent conflicting opinions on this question, with no common purpose, as inexpedient if not discreditable. Plunkett and Dawson firing red-hot shot into each other, at point-blank distance! I consider the approximation which I have sketched, governed by the reservations which I have detailed, as safe and creditable-and, supposing such a middle course to be matter of discussion in the Cabinet, in my humble judgment, the party rejecting it would be the party on whom the real responsibility of separation would rest. 
[PS.] I never communicate with $\mathrm{M}^{\mathrm{r}}$ Canning, or rather he never does with me, but it is but justice to him to tell you that there is an "on dit" floating about society, private and political, Catholic and Protestant, that he has overtly said, that he would never consent to the formation of any Government, upon any other than a conceding basis. There are other reports of his having been in negotiation with the Whigs, which haunt Club houses and talkingcorners, but these are, I think, beneath contradiction.

(Add. MS. 38749 , ff. 14 I-5.)

\section{The Duke of Wellington to Sir William Knighton.}

London. 2 March. [The Duke's draft.]-I was about to write to you when I received your note of yesterday. I am very sorry indeed to find that you have had a relapse. . . . I really know nothing which should give occasion for my troubling his Majesty. [Matters remain exactly in the same state as when the misfortune happened to Lord Liverpool.] ${ }^{1}$ But I shall be ready to attend H.M. commands whenever H.M. may express a wish to see me.

(Wellington MSS.)

\section{Edward Blount to E. J. Littleton.}

Norfolk House. Monday evening. ${ }^{2}$ March 2.-Tomorrow at the half past two or a little earlier, Lord Duncannon, Spring Rice, Macdonald, Newport and Calcraft, meet at Norfolk House to go through the list of members of the House of Commons to learn the strength of the unbending parties on the Catholic question which is to come on on the $5^{\text {th }}$, and I am requested by the Duke of Norfolk to say that if you can lend us your valuable assistance on this occasion it will be highly acceptable.

(Hatherton MSS.)

\section{I. The Duke of Rutland to Mrs. Arbuthnot.}

5 March.- . . The political decease of poor $L^{d}$ Liverpool is indeed a heavy blow to the State $\&$ to the party of which he was the point d'appui. We are all standing upon tiptoe in anxious expectation of the arrangements which must be consequent upon

1 This sentence is scored through, but it is just legible.

2 The $5^{\text {th }}$ of March was a Monday. 


\section{2 \\ THE FORMATION OF CANNING'S MINISTRY}

it. . . My eyes have been incessantly since the abeyance of Lord Liverpool's faculties, turned towards your excellent \& highly talented friend the Duke of Wellington. I know how much he attends to your advice \& judgement, \& though I am not insensible to his good taste in the feeling which he has for you, yet I am sure your amour propre will not be sickened at my saying that you ought to consider his friendship \& regard as the greatest glory \& agrément of your life. Cannot you put it into his head to become the head \& champion of the party which it is the fashion to say has received its deathblow by the two inflictions which in two short months it has sustain'd ? . . .

(Arbuthnot MSS.)

\section{Lord Binning to Sir Charles Bagot.}

London. Tuesday, 6 March.- . . An adjourn'd debate last night. Victory in talk-more compleatly on our side than ever. All spoke well on our side-all ill on the other. It will be the same thing tonight and this is a question on which the debate always tells. The result however is by no means as certain as I wish it was. I continue to believe - notwithstanding the misgivings of :some last night - that we shall have a majority-but I am alarm'd at the doubts that seem'd to be entertain'd on that subject. The industry of the Protestant runners is immense-and they have the advantage of two Secretaries of the Treasury on their side-to say nothing of that Irish rascal black Holmes. ${ }^{1}$ They are industriously circulating the opinion that we who vote for the Catholics, but are friends of Government, ought to pray heartily that we may be beat-because in that event the necessary ministerial arrangements will be made with ease-whereas-if we conquer-the Govern ${ }^{t}$ must break down. This is most mischievous and is but too likely to tell-especially when one remembers that by telling -on ten fools \& making them vote Protestant, a difference of twenty is created in the division \& that 27 or 28 form'd our best majority in I825. You will admit that this is nervous work. Their calculation or pretended calculation of the facilities to be afforded on their assumption in the forming of a Govern ${ }^{t}$ is not worth a farthing - unless-as I wrote to you before - their victory is compleat \& decided-\& that it cannot be. It is not in the cards-\& never can .be again. On the other hand if we carry it-by ever so small a 1 "Billy" Holmes, the Tory Whip. 
majority (though a decimal figure of 3 or 4 would be best) it goes far to put the game in Canning's hands- $\&$ our Protestant warblers would soon smooth their troubled feathers \& learn to pipe the prescrib'd tune to their new master. Confound them-I have known them too long not to be aware of their character-\& there are some 20 or 30 of them that I should like to ship off to N. South Wales. If I thought them right in their calculation-I have too strong a feeling on this immense question to be sway'd in my wishes for one single moment by any such considerations- $\&$ yet it may be suppos'd that I am tolerably anxious about the new arrangement of the Cabinet. Everything on that point is still in abeyance\& must I suppose continue so until Lord Liverpool resigns. I think the persuasion becomes more \& more general that Canning must be at the head-but experience has taught me not to be sanguine on such matters. The King has immense power-and all Kings know how to dissemble \& play their cards to advantage. I profess I do not see how they can form a Protestant Governt but then one has seen such things in the formation of Cabinetsespecially if supported by Rex and a cry-that I prepare myself for any possibility-however bare it may be. But hang it-I do not see the possibility with Peel unwilling $-\&$ in the good state of mind in which he is $-\&$ with the wretched materials they have besides. But there are difficulties on every side and one loses oneself in a maze of anticipation \& conjecture. Now you can anticipate \& conjecture as well as I can-\& I leave you to smoke it all in your best pipe.

I agree with all you say about the F.O. \& Treasury. I rather had leanings the other way-but I am inclin'd to think I was wrong. Lord J. Townshend has written most earnestly to Canning to warn him not to remain at F.O. holding up the example of Fox-who was censé to be Premier with the same seals-but who fail'd in being so, when old Portland was at the head of the Treasury forty odd years ago. Fox never he said repented it but once. What I should like would be to have Canning First Lord-\& Husky Chancellor of the Exchr. This would give him leisure to superintend the F.O. \& plenty of holiday time \& ease. But alas for Huskisson !!!! He is very very unwell-I will not think dangerously so-but we are all uneasy about him. He is very weak$\&$ it is a poor little voice that comes from his chest-which is- \& has long been sadly oppress'd. There is something wrong there. I trust it will be set right-but it is not pleasant. I heard yesterday 


\section{THE FORMATION OF CANNING'S MINISTRY}

that he was rather better. They are blistering his breast- $\&$ he coughs too much-but that is I believe from the trachea. . . .

[PS.] You forget my boy that the salary is taken from the Cinque Ports-that is-next turn there will be none-but there are lands I believe to a small extent- $\&$ some advantages besides power. ${ }^{1}$ It ought to be so- $\&$ I hope will. It would be perfectly compatible with his retirement as Secretary-\& would give him a residence too. I had not heard of the King's diatribe agst emancipation but I did hear yesterday. Cela ne fait rien. Beau Clarence is for it. ...

(Bagot MSS.)

\section{Thomas Spring-Rice to E. J. Littleton.}

26 Baker Street. Wednesday, $8^{\text {th }} 2$ [March].-We meet tomorrow en petit comité at Norfolk House to consider what course we ought to pursue. Plunket, Lord Lansdowne, Macdonald, etc. will be there about half past one, or one. Can you come to assist us? Great interests in both countries-the very existence of Ireland-all in short is at stake. God forgive those whose folly and wickedness have overthrown our hopes for a time-but it is for a time only.

(Hatherton MSS.)

\section{George Canning to the Earl of Carlisle.}

Foreign Office. 7 March. Private and Confidential.-Should you like, or dislike to be a member of the Committee on corn, which

${ }^{1}$ Since 1778 , except during the years $1806-12$, the office of Lord Warden of the Cinque Ports, which the Sovereign regarded as a private piece of patronage, had always been given to the Prime Minister, and Lord Hawkesbury, as he then was, would have had it in 1806 as Prime Minister had he not declined the King's invitation to form a Government. The office had been worth sometimes $\notin 3,000$, sometimes $\{4,000$ a year gross, but Lord North said he had not received more than about $f \mathrm{I}, 000$ a year net (Parl. Hist., xx. 926). Lord Camden wrote to Wellington in August 1828 , when Lord Liverpool's death was daily expected, "... Upon the idea that you may not be aware of some circumstances relative to the office of Warden of the Cinque Ports, I think it right to inform you, that although the salary was abolished in 1817 , the office still exists, that a very trifling salary is annexed to it, but it gives the possession of Walmer Castle and the patronage of Dover and of Deal Castles, and I believe of two others, and also considerable influence in Dover and Sandwich . . ." (Wellington MSS.)

${ }^{2}$ Evidently a slip for the $7^{\text {th }}$. 
is to be named tomorrow in the House of Lords? I do not presume to ask your opinion on the plan of the Government. But I ought in fairness to say that I put the question, which I do put to you, on the presumption that your opinion is not absolutely adverse-as Lord Lauderdale names those members of the Committee who are in his sense upon the subject-and it is therefore, naturally the wish of the Gov't to name such as are at least impartial upon it. Could you let me have your answer tomorrow morning, in order that I may let Ld Bathurst know it before the meeting of the $H$. of $L^{d s}$ ? 1

(Castle Howard MSS.)

\section{Earl Bathurst to the Duke of Wellington.}

Stanhope Street. 8 March. Private.-Lord Bagot told Lady Bathurst yesterday in the strictest confidence that the King had written the most kind \& gracious letter to her, desiring that on no. account Lord Liverpool should have his attention called to his present situation, with a view of his resignation; that the King was determined to wait the result of the recovery to which it was hoped Lord Liverpool might look, \& that he would take no measures for replacing Lord Liverpool until upon his own view of the case, he should find it indispensable for him to make the change. Lady Liverpool has not divulged this letter to any one except Lord Bagot, $\&$ one or two others of the family, \& to them under promise of secrecy. ${ }^{2}$ Whether there was anything in the letter or any other letter which recommended this, does not appear. If however you have not heard of this measure you will on no account mention it, but you will send this note on to Peel. ${ }^{3}$

(Wellington MSS.)

1 Lauderdale's motion on the 8th for the appointment of a Select Committee was agreed to. (Parl. Deb., N.S., xvi. Io20-33.) Bathurst took charge of the parliamentary business in the House of Lords which had devolved on Lord Liverpool.

${ }^{2}$ Lady Liverpool's father, Charles Bagot (who assumed the surname of Chester), was Lord Bagot's uncle.

"The Duke of Wellington's pencilled docket: " I have heard that the King had written to Lady Liverpool; but I did not hear the exact contents of the letter as here given." The letter is endorsed by the Duke : "Comm" from the King to Lady Liverpool. Observation of $M^{x}$ Peel inclosed." 


\section{THE FORMATION OF CANNING'S MINISTRY}

\section{The Marquess of Tavistock to John Cam Hobhouse.}

Oakeley. Thursday, 9 March.1-Having sacrificed my own opinions and consistency, and the decided feelings of my constituents in deference to the wishes of others upon this business of the Catholics, I beg you will take an opportunity of telling Burdett that I must follow my own course another time, altho' I cannot think that he will ever meddle with the subject again, till his Majesty thinks fit to call to his counsels a Cabinet united on the subject. The farce supported by us, has existed now sufficiently long to open the eyes of every one. Our majorities have been gradually growing smaller and smaller, till at length we have been left in a minority, with the country more against us than at any former period, by Canning's own confession. Whether this confession was wise and prudent, and whether it looked like sincerity must be left to others to decide, but how after having suffered $\mathrm{Parl}^{\mathrm{t}}$ to be chosen under the immediate influence of a No Popery Secretary to the Treasury, under the direction of a No Popery junto, after having permitted this faction to use all its influence against the Catholics in the late division, how after this, a different result was to be looked for, is to me quite surprising. Every trick, and every kind of corruption was made use of at the general election to procure a majority against the Catholics, and this was more than connived at by Canning. I could prove this to you in 5 minutes. ${ }^{2}$

After all, however, I am glad we were beat, because it will open people's eyes, and set the question at rest in its present shape. It must put an end to the support we have given to the political juggle which has existed for so many years between one set of Ministers and another for the official convenience of both, and to all further delusion on the subject. . . .

(Add. MS. 36463 , ff. 304-6.)

1 Thursday was the 8th.

2 According to Canning, Lord Liverpool was scrupulously impartial in giving :away Government seats at the I826 elections, " for of ten seats placed at his disposal, half were given to Protestants and half to Catholics." That impartiality, added Canning, was not observed by the Prime Minister's subordinates. "I believe that . . . after his seizure, and at the moment when the Catholic question was brought on for discussion, no effort was left unestablished by those into whose hands the power of the Treasury fell, to influence the decision in the way in which it actually turned." (Wellesley Papers, ii. 16i.) 


\section{Sir Robert Wilson to Earl Grey.}

House of Commons. 9 March.-The Court by a whip unprecedented and a rake of even Wilks ${ }^{1}$ from France has beaten us by 4 . It was expected by some of the knowing ones, for we calculated on voting and pairing above 295, but casualties and neglect of duty deprived us of all but the number of 272 voters and I7 pairs. Amongst the number of defaulters were 4 Irish in $\mathrm{p}$ [air]s, one of them, however, Daly, is accounted for by the promise of a peerage. ${ }^{2}$ Even as it stands now a favourable Crown would carry the measure by above 70 , which additional force it commands already. The debate was most remarkable.

It is supposed by most there must be a dismemberment of the Cabinet. Indeed there is a strong feeling out of doors that such a measure is absolutely necessary for the respect of Govt, and the Speaker told me yesterday he thought changes had become imperatively necessary, but then in a week the eyes of the publick would be opened on the subject. . . .

$$
\text { (Add. MS. 30124, ff. 259-63.) }
$$

\section{The Hon. F. Cathcart to Sir Charles Bagot.}

F.O. Friday, 9 March. Private.-An immense bustle has been created since I wrote last by the result of the debate on the Catholic question, not from the state of the votes, for that was anticipated, \& might as easily be the other way the next opportunity, as it was the accidental illness or absence of Huskisson \& two or three other members that turned the scale. But it is the tone $\&$ character (so very different from what often occurs from the mere heat of the moment) of the speeches of Peel in reply to Plunkett, \& $\mathrm{M}^{\mathrm{r}}$ $C$ [anning] v. the Master of the Rolls, that seem to render it pretty evident that the scheme of a divided Cabinet can no longer stand. For although they profess to be perfectly agreed on all but one question, yet as that one question happens to be confessedly of vital \& paramount importance, it is not easy to see how either party can consent to remaining any longer in its present state of

1 John Wilks, M.P. for Sudbury. He subsequently took the Chiltern Hundreds, and the succeeding by-election took place on 9 April 1828 .

2 James Daly, M.P. for Galway County (d. 1847), was created Baron Dunsandle in the Irish peerage, in 1845 . He voted for the Relief Bill in I829. 


\section{$3^{8}$ THE FORMATION OF CANNING'S MINISTRY}

armed neutrality. Accordingly the antiCath ${ }^{3} \&$ ultras of all sorts are running about proclaiming their triumph as certain $\&$ immediate, that $L^{d}$ Bathurst is to be Premier, to be backed by the Seymours $\&$ God knows who besides; $\&$ in short, that the dreadful liberal taint is soon to be totally removed from the Cabinet. Of course I need say nothing about the absurdity of all this, \& I only give it you as part of the lies of the day, amongst which must be reckoned the report of Mr C. having actually sent in his resignation. $\mathrm{He}$ is, I am happy to say, quite well, \& not the worse for his exertion on that night or the very great excitement he underwent, of the degree of which, his speech, even as reported, will give you an idea. He is able to dine out $\&$ appears to be in his wonted force $\&$ spirits.

The idea of Robinson's becoming a Peer \& Foreign Secy, seems to hold its ground \& it is thought that Huskisson would be Chancellor of the Excheqr, which of course would relieve $\mathrm{M}^{\mathbf{r}} \mathrm{C}$. from a great load of business, or at least enable him to superintend more easily \& effectually the whole concern, particularly the foreign relations. . . .

(Bagot MSS.)

\section{The Marquess of Tavistock to John Cam Hobhouse.}

Oakeley. Io [March].-I did not mean to say that Canning is not sincere in wishing to carry the Cathe question. Undoubtedly he $\mathrm{w}^{\mathrm{d}}$ be glad to carry it, and to keep his office ; but if he cannot have both, he had rather keep his place than lose both. This is all I meant to say with regard to his sincerity. But two or three facts have lately come to my knowledge about his conduct on the subject of seats at the general election, which puzzle me, and make it very difficult to reconcile his professions with his actions. . . .1

(Add. MS. 36463 , ff. 307-8.)

1 " I still cling to my opinions," he wrote again three days later, " but I don't like to be obstinate in these matters, or to stand aloof from my friends. If Ireland is in such a wretched state, it is more than ever the business of the Govt to take a decided line, and let us support or oppose their measures as we find them to be good or bad ..." (Ibid., f. $3^{1} 5$. .) 


\section{The Duke of Wellington to Charles Arbuthnot.}

London. II March.-I will read Mr Herries' $\mathrm{Mem}^{\mathrm{n}}$ and return it to you. ${ }^{1}$ I am certain that a Comee will not answer. It will not be very desireable for the old, or fair towards the new Govt. Have the old Govt carried into execution the measures of reform recommended by former Committees? Ought the business of the new Gov't to be put without their consent in the hands of a Committee? What is wanting everywhere and in everything is the hand of authority!! and upon this we may rely, that whether with or without the assistance of a Committee, if somebody does not soon govern this country with a determination to be obeyed and to cut up these expensive jobs by the roots, the whole machine will fall to pieces.

(Arbuthnot MSS.)

\section{5r. John Wilson Croker to Robert Peel.}

I7 March.-I have just heard from one that wishes you well, that notice has been taken that you have been asking to dinner all the members of the anti-Rom. Cath. majority, without the addition of a single friend of Government of the opposite sentiment on that subject. See what a system of inquisition we live under! I know that you are giving, as you ought to do, House of Commons dinners, but $I$ think it right to apprise you of the turn given to your hospitality.

(Add. MS. 40319, ff. 213-14.)

\section{John Wilson Croker to Robert Peel.}

I8 March.-I suppose you have had an account of the King's conversation TO Becket. If you have not, you should hear it from some good authority. I have it only from a third hand but from what I hear, I believe his Majesty expressed his real sentiments on the Cath. question.

(Add. MS. 40319, f. 215.)

1 He advocated the appointment of a Finance Committee of the House of Commons to inquire into the state of the national finances. (Life of Herries, i. 139-44.) 


\section{THE FORMATION OF CANNING'S MINISTRY}

\section{George Canning to Robert Peel.}

F.O. 22 March. Most private.-Would it not be well that we should have a Cabinet tomorrow to receive the D. of W[ellington]'s report of his visit to Windsor : and to consider, whether, if nothing has passed at this visit, it may or may not be expedient to make any direct communication to the King ? ${ }^{1}$ Shall I summon a Cabinet for 3 -and give the $\mathrm{D}$. of $\mathrm{W}$. notice of it ?

(Add. MS. 40311, f. 263.)

\section{Robert Peel to George Canning.}

Whitehall. 22 March. Most private. (Copy.)-I can see no objection whatever to a Cabinet tomorrow. It seems almost impossible that the King would not allude to the observations which have lately been made in both Houses with respect to the state of the Government. Michael Angelo Taylor being in a rage that due attention was not paid to something he was saying about the Navigation Laws last night, alluded to the subject, and intended to be very sarcastic, but everyone laughed at him. ${ }^{2}$

(Add. MS. 40311, ff. 265-6.)

\section{George Canning to Robert Peel.}

F.O. 23 March. - . . I have received just now a command to Windsor for Tuesday, which, though it has nothing to do with the present crisis (being merely to meet the Granvilles and Lievens at dinner) will nevertheless render it additionally desirable that something in the way of explanation should take place on Monday. ${ }^{3}$ (Add. MS. 403II, ff. 267-8.)

\section{Robert Peel to his Father.}

Whitehall. 23 March. (Copy.)-I merely write a line for the purpose of saying that nothing has passed with respect to the future state of the Government since I last wrote to you. The

1 See No. 66. On the 21st Canning wrote to Knighton expressing a wish to see him the following morning. (Ann Arbor MSS.)

2 This debate is not reported in Hansard.

3 The state of the Ministry does not appear to have been alluded to in Parliament on Monday the 26 th. 
King would wish I have no doubt, to postpone the consideration of any arrangement until the Easter holidays, when there will be a little leisure from the pressure of parliamentary business. There begins however to be a little impatience in each House of Parliament. (Add. MS. 40393, f. 40.)

\section{The Duke of Rutland to Mrs. Arbuthnot.}

Belvoir Castle. 23 March.-I wish most heartily that your last letter could have told me of the arrangement of a Government, \& if you desire to know my real feeling, it would have pleased me most to have heard that the Duke of W. was the Premier. I am firmly convinced that there is no man of the party, which ought to furnish the head of the Government, who has a comprehensiveness \& energy of mind equal to his. You will thus understand that my part of the acclamation which you say would alone induce him to come forwards, would be cheerfully and ardently given. But I speak only my own feeling, for I know not what are the sentiments of others who ought to assist in forming the bundle of sticks. It has been surmised that the Duke would never give up the Horse Guards for the Treasury, \& that the publick would not hear of the two situations being concentrated in one man. And indeed the duties of each are so important and so tremendous, that the wear $\&$ tear which one of the offices must make on the mind of the holder, must be most serious-and unless he who might hold the two, could establish a manufactory of time, \& make I 8 hours out of I2, I suppose they would be incompatible. Then it is suggested that he might have a deputy at the Horse Guards transacting the duties of that office, but acting under his controul. I should fear the policy of such an arrangement, and that it would never be long palatable either to the parties themselves or to the publick. Would that some arrangement could be made which would give us a Protestant Treasury, with our favourite Duke at the head of it! You justly observe that the late small Protestant majority, though insignificant of itself, is important, inasmuch as it gives us the right to contend that the Parliament \& the country both wish for a Government exclusively Protestant; indeed it is time that the disgraceful division in the Cabinet on a question of vital importance should be put an end to. . . .

(Arbuthnot MSS.) 


\section{THE FORMATION OF CANNING'S MINISTRY}

58. The Marquess of Lansdowne to Sir Robert Wilson.

Richmond. Sunday Morning, 25 March._... I am satisfied the general disposition of persons in opposition is [to] do what is right in principle and support $\mathrm{C}$ [anning] in all in which he deserves to be supported-but I should be very adverse myself to any meeting either at Brookes' or elsewhere. Where the position is so delicate, it is very difficult when numbers are brought together, it is difficult to do enough and not to do too much, and it would be the subject of idle conversation and newspaper reports or rather misrepresentations. C Canning] is now fully in possession of my sentiments through the most unexceptionable channel.

PS. Of course what I have said about communication does not apply to the particular expressions you hinted at and which I quite agree with you it would not be desirable to repeat verbatim. ${ }^{1}$

(Add. MS. 30115, ff. 185-7.)

\section{George Canning to Robert Peel.}

Royal Lodge. 29 March. 2 a.m. Private.-You will receive a summons from the King, to wait upon his Majesty early tomorrow morning. ${ }^{2}$ I wish I could see you this evening. I shall not be in town till late. Would you allow me to send to you at the House of Commons, and would you take the trouble of coming to me for a quarter of an hour when I send ?

(Add. MS. 40311, f. 272.)

\section{Robert Peel to George Canning.}

Whitehall. 29 March, $\frac{1}{2}$ p. 5. (Copy.)-I will come from the House to the F.O. some time this evening. . . .

(Add. MS. 403II, f. 274.)

1 The letter is endorsed : "Lord Lansdowne in continuation of his letter and in comment upon the minatory parts of Brougham's $I^{\text {st }}$ note." See Sir Robert Wilson's Narrative, pp. 4-ro, for these Whig overtures to Canning.

2 See No. 66. 
60A. The King to Robert Peel.

Royal Lodge. Thy $h^{y}$ 29 March. Private.-[Desiring him to go to the Royal Lodge the following day at twelve.]

(Add. MS. 40300, f. 189.)

\section{6r. George Canning to Sir William Knighton.}

Royal Lodge. 29 March, 8 a.m. Private.-I do not mean to be in Downing Street today before dinnertime, because, if I arrive sooner I shall be besieged with inquiries. I shall expect you about 9 .

F.O. 29 March, $\frac{1}{2}$ p. Io [p.m.] Secret.-You said just now that you would tell H.M. that there was nothing left for it, if he would do so \& so-but to take the person whom I am expecting here tonight. Now, do not say that. The advantage of the present project is its ineffable absurdity. It is against it that I have protested. Let me have a fair trial with $i t$, before any new plan is brought forward. Indeed I do not see how they could, in common honesty, take advantage of my refusal to agree to one plan, to substitute another.

Ibid., $\frac{3}{4}$ p. II $[p . m$.$] Secret.-P[eel] has just left me. What his$ ultimate decisions may be-or might be-I cannot say. But it is impossible to do more than justice, by any expression of mine, to the frankness $\&$ generosity, \& self-denial, of his declarations. I thought it right that you should know this-but I direct that you shall not be disturbed tonight with my letter.

(Ann Arbor MSS.)

\section{The Duke of Rutland to Mrs. Arbuthnot.}

Biggleswade. 3I March.-I send the $\frac{1}{2}$ a dozen lines from hence, knowing your anxiety. Yet am I able to say little more to you than I did yesterday. You must be aware that a visit from myself to headquarters ${ }^{1}$ is not like a visit from a person who goes thither professedly, avowedly \& exclusively to converse upon a particular subject. It was certain that many \& various would be the subjects of a conversation with me, \& this certainty was realized. But I think that under the circumstances I said as much as I could be expected to say-perhaps more, \& yet not so much as I should

\footnotetext{
1 Windsor.
} 


\section{THE FORMATION OF CANNING'S MINISTRY}

have said, if I had said all that I wished. I should have much difficulty in forming a guess as to future probabilities. An intention was expressed of acting with firmness, \& of not flinching from a duty the importance of which was most unequivocally allowed, but at the same time it was observed that there was a necessity for fairness \& impartiality. I should think that we may expect things to go on \& matters to be cast in the same mould as that from whence the proceedings of the last years of Ld L[iverpool]'s Administration were taken, \& nothing more. Some importance was attached to the continuance of the security of our foreign relations, \& their present position seemed to be considered as very perfect. This would imply that Mr C[anning] would remain where he is. But a very strong observation was made of continued \& staunch attachment to the cause of Protestantism. There was a moment 'when I endeavoured to express my admiration of the $\mathbf{D}$. of W[ellington]'s straightforward principles, \&c., but I have a doubt whether I was correctly heard, \& the subject was put by (not designedly I am convinced) for one of a lighter character. I shall expect intelligence from you in the next instance. I am not likely to hear more. You on the contrary will be in the focus. of intelligence and will be able to communicate information to me. I should add that much satisfaction was expressed at the determination of all those who feel so much anxiety on the subject of the pending arrangements to do nothing which could distress \& embarrass at the present moment. I write in haste but I thought you would like an early line. You will I am sure consider it quite confidential. ${ }^{1}$

\section{(Arbuthnot MSS.)}

\section{The Duke of Buckingham to the Duke of Wellington.}

Buckingham House. I April.-Mr Canning having declared in the House of Commons that his Majesty is now taking steps to form an Administration, ${ }^{2}$ I think it due to myself to state to you, as my personal friend, the situation in which I find myself. Your Grace is well aware, having been yourself a party to the discussions leading to my connexion with Lord Liverpool's Government, that

1. The Duke's letter does not support Professor Temperley's statement that the Duke suggested that Bathurst should be put at the head of an antiCatholic Ministry. (Foreign Policy of Canning, p. 426.)

2 See Parl. Deb., N.S., xvii. I66 (3o March), and No. 66. 


\section{THE FORMATION OF CANNING'S MINISTRY 45}

Mr Williams Wynn was named by me as the representative of my interest in that Cabinet, and as such was appointed President of the Board of Controul.

In the formation of a new Government upon the basis of the former, I am prepared to take my part, and to support it when formed, if its constituent arrangements are such as will render it possible for me to do so. But I owe it to myself to state distinctly that Mr Williams Wynn from circumstances which it is not necessary for me to detail, is no longer considered by me, as my representative in the Cabinet now to be formed, and I am authorized to say that no part of the support of my friends will attach itself to him in that situation, or through him to the Government. Of course, I cannot possibly foresee in what manner the new Government will be formed. But I beg expressly to state to your Grace as my private and personal friend, that should the arrangements now contemplated be such as I can support in principle, my personal objects are now confined to the Governor Generalship of India, and to a subordinate situation in the Government at home to be given to one of my friends, as proposed in the first instance by Lord Liverpool. Should therefore the constitution of the Government be such as I can support, I have now placed in your Grace's hands the terms on which I am content to give it my personal assistance \& co-operation, being satisfied that your Grace will make such use of this letter whenever the proper time shall arrive, as will best tend to the King's service and gratify your friendly wishes in my favour.

(Wellington MSS.)

\section{The Duke of Wellington to the Duke of Buckingham.}

2 April. (Draft.)-Although I am to have the pleasure of seeing Lord Chandos this morning, I write an answer to your letter of yesterday; and I am anxious that you should receive it before Lord Chandos will leave you.

[I don't believe that H.M. has yet made his arrangement respecting his Ministry. Till that arrangement will be made it will be impossible for me to tell whether I can state the case of any person whatever. It is useless then now to enter upon such case. But I cannot avoid to say one word [sic] respecting Mr Wynne.] ${ }^{1}$ As well as I recollect what passed when $\mathbf{M r}^{\mathbf{r}}$ Wynne was appointed to

1 This portion is scored out. 


\section{THE FORMATION OF CANNING'S MINISTRY}

the office which he now fills, you expressed a wish that Mr Wynne should have an office which would according to the usual practice give him a seat in the Cabinet ; and Lord Liverpool, Lord Castlereagh and others who were at that time H.M. Ministers considered Mr Wynne's talents, character and station such as to render him an acquisition to the Cabinet. This I believe to be the real state of the transaction; and I don't think it was ever admitted that it was necessary that a connection of yours should as such be a member of the Cabinet.

I have much regretted the circumstances which have occasioned a division between yourself and Wynne ; but I must say this, that I cannot be the bearer of any communication which has for its object to remove Wynne or any other colleague from his seat in the Cabinet. Although I have thought it right to trouble you so far upon this part of your letter, the fact is that $I$ have not heard that the King has yet made any arrangement respecting the successor to Lord Liverpool. You know my sentiments already respecting the office of Govr General.

(Wellington MSS.)

\section{The Duke of Buckingham to the Duke of Wellington.}

Minchenden House. 2 April.-I feel it absolutely necessary that your Grace should be undeceived on a most material point on which you are compleatly mistaken, \& the mistake is the more remarkable because your Grace yourself wrote me a letter sometime after the arrangement between $\mathrm{Mr}^{\mathrm{r}}$ Wynn \& the Government was compleated in which you yourself state that you considered $\mathrm{Mr}^{\mathrm{r}}$ Wynn as MY representative in the Cabinet. I have not this letter before me, but I could find it, as I know that $I$ retain it, and I beg to recall to your recollection the occasion of your writing it. It was when I hinted to you my own wishes, upon a distinct understanding entered into between Lord Liverpool and myself that a Cabinet or official arrangement should be made for myself. Your Grace's letter was directed to me either at Leamington or Cheltenham, I forget which, and I fear the letters of that year are at Stowe. But I pledge my honor to the fact. Fortunately the terms of $\mathbf{M r}$ Wynn's admission into the Cabinet rest upon the testimony of Mr Fremantle who was the bearer of the first communication from Lord Liverpool to me, I being in Hampshire, and are reduced to writing. I have sent this letter open to $\mathrm{Mr}$ Fremantle and have 
requested him to be the bearer of it to your Grace and to inform you, upon his honor, the particulars. The papers I will lay before your Grace, the moment I return to London, which will be tomorrow, and I request your Grace to appoint a meeting at my house on Wednesday for that purpose. By both the oral evidence of $\mathrm{Mr}^{\mathrm{r}}$ Fremantle and the written evidence which I shall have the honor to lay before you, your Grace will see that $\mathrm{M}^{\mathrm{r}}$ Fremantle came to me by the desire of Lord Liverpool to tell me that H.M.['s] servants had with his Majesty's concurrence, determined on making to me the following proposition viz-that I was to nominate any one friend to a Cabinet office and any other to an office short of Cabinet, and his Majesty besides empowered Lord Liverpool to say that under the circumstances of the promise made to my late father $\mathrm{H}$. Majesty would confer upon me the dignity of a dukedom. I affirm upon my honor that neither directly nor indirectly was $\mathrm{Mr}$ Wynn's name mentioned to me by or from Lord Liverpool. I affirm upon my honor that Lord Liverpool never heard of $\mathrm{M}^{\mathrm{r}}$ Wynn's name as a Cabinet Minister, until I informed his Lordship on my first interview with him after $M^{r}$ Fremantle's interview with me that I meant to recommend Mr Wynn to him for the Cabinet office-and I also affirm upon my honor that I felt myself at liberty to recommend any other person had I so chosen, and should have had a claim on Lord Liverpool for his nomination, had he been a fit person to have filled the office of a confidential Minister of the Crown. Upon such part of this statement as comes within his knowledge I refer your Grace to Mr Fremantle. The letter which I shall lay before you will confirm the whole and $\mathrm{M}^{\mathrm{r}}$ Wynn can deny no part of it.

It having thus been determined by H.M.'s Government to receive my assistance upon the terms above mentioned and no other, I am now to say distinctly that $\mathrm{M}^{\mathrm{r}} \mathrm{Wynn}$ has lost my confidence, that no part of my support or that of my friends follow or will follow his being in the Cabinet, and that my personal assistance to the Government now about to be formed, depends, should I be able to support in principle its constituent formation, upon the appointment of Governor General of India being given to me \& a subordinate office being given to one of my friends, if approved of by the Cabinet. I further state that Mr Williams Wynn does not speak my sentiments, and therefore I trust should they be in any respect referred to, they will be referred to personally to myself, and not to one with whom politically I am wholly disconnected. I feel 


\section{THE FORMATION OF CANNING'S MINISTRY}

most gratefully your expressions of recurrence to the favourable opinion which you before notified to me of my fitness to be appointed to the office of Governor General of India.

PS. This letter is not marked private in order to enable your Grace to lay it before whomsoever H.M. entrusts with the formation of the new Administration.

(Wellington MSS.)

\section{Henry Hobhouse's Diary.}

Monday, 2 April.-As soon as Mr Canning's health enabled him to move, he came to town, having first had an audience of the King, in $\mathrm{w}^{\text {eh }}$ he declined (as $\mathrm{M}^{\mathrm{r}}$ Peel had done) entering into any conversation respecting the state of the Administration. The King shortly afterw $\mathrm{d}^{\mathrm{ds}}$ left Brighton, and returned to Windsor; and with the exception of coming once to $S^{t}$ James's to hold a Council, saw none of his Ministers till ten days ago. In the mean time the business of the Session of Parlt proceeded, except that the projected Corn Bill ( $w^{\text {ch }}$ was to have been opened by $L^{d}$ $L[i v e r] p o o l$ in the Ho. of $L^{d s}$ at the same time that it was proposed by $\mathrm{M}^{\mathrm{r}}$ Canning in the Commons) was confined to the lower House, and that no vote of money was brought forward beyond the Army, Navy and Ordnance Estimates. For a long time no observation was made in either House with regard to the state of the Ministry, but it was at length noticed by $\mathbf{M}^{\mathbf{r}}$ Baring in the lower, and by $\mathbf{L}^{\mathbf{d}}$ Londonderry in the upper House. ${ }^{1}$ Neither of them drew forth any remark either from the Ministers or from any other member. Twelve days ago the $\mathrm{D}$. of Wellington was commanded to repair to Windsor, and it was expected that the King wo ${ }^{d}$ then open himself. But he forbore, and on the Duke's adverting to what had passed in Parlt, the $\mathrm{K}$. intimated that he should let the matter rest till Easter. It became necessary however to obtain a vote .of money, and it being determined that the $\mathrm{Ch}^{\mathbf{r}}$ of the $\mathrm{Exch}^{\mathbf{r}}$ should last Monday move for $£ 200,000$ on accot $^{t}$, it was thought right also to advise the King to make to $\mathrm{L}^{\mathrm{d}} \mathrm{L}$ pool. a communication on the subject of his retirement. His $L d^{p}$ has recovered a good deal of muscular action, but very little speech, and his not having signified any idea of his own retirement is a plain proof that his faculties are so far impaired that he can not be conscious of his

1 By Baring, I9 March ; by Londonderry on the 2oth. (Parl. Deb., N.S., Xvi. I268, I280.) 
own situation. The King, who had before apprized Lady Liverpool of his intention of awaiting $L^{d} L$ L.'s amendment, now sent Sir $\mathrm{W}^{\mathrm{m}}$ Knighton to communicate to her that the public service wo ${ }^{\mathrm{d}}$ not admit of longer delay. Her Ladyship apprized her Lord, who appeared to understand and acquiesce in the proposition. $\mathrm{M}^{\mathrm{r}}$ Robinson made his motion on the appointed day ; it was expected that it wod be opposed on the ground that the Administration wanted a head ; but no such opposition arose ; and that, altho' Mr. Baring was in the House, and was called on by Mr Hume to follow up what he had said on a former night. This silence excited a belief that it wo be continued till after Easter. But this was not the case, for on Friday, when the Resolution of the Committee was to be reported, $\mathrm{M}^{\mathrm{r}}$ Tierney took the ground of objection, $\mathrm{w}^{\mathrm{ch}}$ was anticipated on the preceding night. In the mean time the King, who had been apprized of Tierney's intention, had seen the $D$. of Wellington, Mr Canning and $\mathrm{Mr}^{\mathrm{r}}$ Peel at Windsor. He explained to them severally, his wish that the present Ministry sh $^{d}$ remain, putting at their head a nobleman of anti-Catholic principles. [The King at first proposed that the Cabinet shod elect their own head, and directed Canning to make a communication to the Cabinet to this effect. But upon Canning's reducing the message into writing, it was determined that it $\mathrm{sh}^{\mathrm{d}}$ not be delivered until the King had seen Peel. Peel objected upon principle to the delegation by the King of this act of royalty, and also deemed the proposition futile. And it was abandoned.] ${ }^{1}$ This was galling to Canning, who fully expected to be called on to take the lead of the Administration, and his disappointment was observable in the House on Friday, when he answ ${ }^{d}$ Tierney, and declared the King's announcement to Lady Lpool. His chagrin, arising from this cause, was greatly augmented from what passed in the House. For when Tierney alluded to Canning's becoming Prime Min, there arose a vociferous cheer from the Opposition benches, $w^{\text {ch }}$ was very faintly returned from the ministerial side of the House. Canning and Peel had an unreserved conference, in $w^{\text {ch }}$ each expressed a mutual desire to continue to co-operate with the other, and admitted the difficulty arising from the difference of their views on the Roman Catholic question. Canning offered a proposition, $w^{\text {ch }}$ originated with the King, that Peel should take a peerage, and take the lead of the Ho. of $\mathrm{L}^{\mathrm{ds}}$, wh Peel peremptorily refused, as Canning expected. He endeavoured also to conciliate Peel by

1 The portion enclosed in square brackets is a marginal note. 


\section{O THE FORMATION OF CANNING'S MINISTRY}

adverting to the state of his own health, and suggesting that the lead of the House of $\mathrm{Com}^{\mathrm{s}}$ has already from that cause devolved in a great degree on Peel, that it was likely to do so in a greater degree, and that if C.'s health sha entirely fail, the Premiership must pass to Peel almost of necessity, if they continued to serve together. Peel disavowed all wish to take the lead of Canning, but stated the difficulty he felt to be this, that considering the part he had taken on the Catholic question, he could not honourably do or suffer any thing, $w^{\text {ch }}$ should advance that question ; that to put at the head of the Govt so decided a promoter of the Catholic cause as Canning, wo ${ }^{d}$ of necessity advance that cause, and Peel could not acquiesce in it, more particularly in his present office ( $w^{\text {ch }}$ he refused to change) where by his countersignature of the $\mathrm{K}$.'s warrants he is personally responsible for the appointment of all the great officers in Church and State, though their selection is in fact made (and, as he admitted, ought to be made) by the Prime Minister. They parted on the best terms, tho' with bitter disappointment on Canning's part, and with a declaration that this conference should not be considered final.

(Hadspen House MSS.)

\section{The Marquess of Londonderry to Mrs. Arbuthnot.}

2 April. Private.-The Duke of R[utland] saw the K. for 2 hours. At first he said, "Come Duke, we must have no politicks or business," but by degrees H.M. talked of everything. The D. in his turn found the opportunity of expressing all he wished \& stated the names of all he had communicated with, as friends to the old Tory system of Lord Liv[erpool]'s Govt. This was received most graciously. The D. then express'd his attachment to a Protestant head. The K. gave him on leaving him a star in diamonds of the Garter of the D. of York. As far as this goes it is good. God grant les suites may be good also.

(Arbuthnot MSS.)

\section{The Duke of Buckingham to the Duke of Wellington.}

Buck[ingha]m House. 3 April. 6 o'clock. Private.-I came to town an hour ago, and I lose no time in requesting your Grace to appoint any hour at which will best suit your convenience, when I can see you to lay before you the papers I adverted to in my 


\section{THE FORMATION OF CANNING'S MINISTRY 5I}

letter of yesterday's date. I am also most anxious to say that upon looking at the papers themselves which I had not with me when I wrote last night, I find that I have overstated a circumstance to you, which I am desirous of correcting. I find that $\mathrm{M}^{\mathrm{r}}$ Wynn's name was originally suggested by Lord Liverpool to me, and not as I had believed, by me to Lord Liverpool. But I assert that the offer of the seat in Cabinet, was made to him only through me, and only in the light of one of my political friends, and that had I refused in the first instance to acquiesce in the arrangement proposed, the offer in question would not have been made to $\mathrm{M}^{\mathrm{r}}$ Wynn and $\mathrm{M}^{\mathrm{r}}$ Wynn would not have had the office. I therefore request your Grace to consider that part of my letter in which I affirm $\mathrm{Mr}^{\mathrm{r}} \mathrm{W}$ ynn to have been first named by me to Lord Liverpool as withdrawn, and as being corrected by this note. The papers, however, which I had not looked at since the arrangement took place, fully bear me out in every part of the material features of the case, viz that $\mathrm{Mr}^{\mathrm{r}}$ Wynn was named, exclusively as my friend $\&$ representative in the Cabinet, that the offer was made only through me, and through no other channel, and formed a part only of a general, arrangement by which the assistance of my family was to be obtained for the Government in Cabinet.

(Wellington MSS.)

\section{W. H. Fremantle to Lord Chandos.}

Stanhope Street. 3 April. Private.-In reference to that part of your father's letter to the Duke of Wellington which you shewed me, I beg to say that the communication made to me by Lord Liverpool and which afterwards I made to the Duke of Buckingham in writing, was that he was to be created a Duke, to name one of his friends to a seat in the Cabinet, and another friend to a. seat at one of the principal Boards, namely, either the Treasury, Admiralty, or $B^{d}$ of Controul.

(Wellington MSS.)

\section{The Duke of Buckingham to the Duke of Wellington.}

Buckingham House. 4 April.-I cannot suffer you to remain for one moment under the error of believing that I meant to write "angry letters" to you. I meant to write explicitly and clearly upon a point on which I did think an entire misconception on 


\section{THE FORMATION OF CANNING'S MINISTRY}

your part had taken place, but pray believe me once for all, that not a doubt of your friendly anxiety for my interests crossed my mind. I did wish that you should interfere, at my desire and for my benefit. I wished it for the sake of old friendship. I wish it now, and I shall feel mortified if you decline, merely from your being mistaken in your conception of the object of my letters or their stile. For respecting you I can have no feeling but that of old \& affectionate friendship.

(Wellington MSS.)

\section{7r. The Duke of Rutland to Mrs. Arbuthnot.}

Belvoir Castle. 4 April.- . . What effect or whether any, my visit to the Royal Lodge may have had, or may have, il reste à voir - nor am I prepared to say that we ought to be satisfied with the continuance of matters as they were during the latter years of $\mathrm{L}^{\mathrm{d}}$ Liverpool's Government. A Cabinet split into two equal parts on a question of immeasurable consequence, \& a succession of measures suggested by the Opposition, \& the effect of which has been to throw every class of the community into distress and dismay, present nothing cheering when viewed in perpetuity. But half a loaf is perhaps better than no bread, \& a Protestant Premier would take care that we shall not run the same hazards which might be expected from one of a contrary persuasion. The King certainly professed himself to be warm \& hearty in the cause of Protestantism, and all his conversation tended to prove the truth of that profession. He laid great stress on the indecency which took place on the first day of Parliament when the Duke of Norfolk appeared in the procession \& stood before the throne habited in parliamentary robes - and he dwelt a good deal on the pusillanimity which allowed the Catholick Association in Ireland a continued existence. I long to point his Majesty's attention to the worth of our Duke, \& I even began a sentence with the expression of my opinion on his merits, but ( $\&$ I am not sure that I was correctly heard) the subject was turned to a portrait of Maria, the Oaks filly, which was in the room, and I must have had the hardihood of a man who, when a lady says "No" with her tongue, insists upon her having "Yes" in her eye, \& acts accordingly, if I had returned to the subject. A few days must determine this most important matter. But I own I do not think Sir Thos Lethbridge goes the right way to work to accomplish the object which all well disposed 


\section{THE FORMATION OF CANNING'S MINISTRY}

persons have in view, by doing what he proposes on Friday next. ${ }^{1}$ Lord Lonsdale came here yesterday . . . I had a long conversation with $L^{d}$ Lonsdale last night. $\mathrm{He}$ is evidently opposed strongly in sentiment \& feeling to Canning, but I collected this more from inference than from any determined declaration of his intentions. ...

(Arbuthnot MSS.)

\section{The Earl of Morley to George Canning.}

Kent House. 5 April.-Without any wish to arrogate any particular importance to my opinion, I cannot help telling you that having reflected upon different points which were (subsequently) adverted to in our conversation yesterday, I am very much disposed to relinquish the opinion which I had previously formed as to the decided preference which I had felt ought to be given to your holding Lord Liverpool's post (of First Lord of the Treasury) instead of retaining your present office. When however I consider the great pecuniary sacrifice which such an arrangement would entail, ${ }^{2}$ the objections which exist in principle to your placing in your present office a mere shadow of yourself (which however would be necessary) the difficulty of finding even such a person-the admirable administration of the Treasury Department as suggested yesterday by Granville-the immense importance of removing all uneasiness from the continental Cabinets as speedily and as effectually as possible--when, I say, all these circumstances are considered, it is impossible not to abandon my former preference, and not to feel that whatever may be the advantages (especially as to domestic impression) which the possession of the Treasury would secure, yet that they cannot be put in competition with those other considerations which I have just enumerated.

As I said before, I am not desirous of attaching any particular value to my opinion one way or the other, but having in point of fact yesterday expressed an opinion to you, and having been since led, upon a view of conflicting difficulties, to alter it, I have felt

$1 \mathrm{He}$ had given notice of a motion for an Address to the King, praying " that he might be graciously pleased to take into consideration, in the appointment of an Administration, the great importance of unanimity in any Cabinet on questions affecting the vital interests of the Empire." Even his ultra Tory friends disapproved of his motion, and on Friday, 6 April, he was persuaded to withdraw it. (Parl. Deb., N.S., xvii. 280-2; 286.)

2 The Foreign Secretary's salary was $£ 6,000$, the First Lord of the Treasury's was $£ 5$,ooo. (Accounts and Papers, $1830-31$, vii. 227.) 


\section{THE FORMATION OF CANNING'S MINISTRY}

that I could not well do otherwise than tell you that I had altered it, as well as state to you the grounds on which I had done so-and having done so, you will probably commit my letter to the flames. (Harewood MSS.)

\section{John Wilson Croker to Robert Peel.}

6 April. Confidential.-I have kept away from you purposely since the night that the announcement was made of a new Administration being about to be formed, because I am unwilling to intrude and to seem to look for information or confidence. You know my wishes, and as I had or have nothing but wishes to offer, I should have felt that I looked like a Paul Pry if I haunted you at this juncture as I have done at other times in far different pursuits. But as I have been by accidental (and, by me, unexpected) circumstances thrown into communication with $\mathrm{M}^{\mathrm{r}}$ Canning, and as after we had talked over the business which brought us together, he has also talked to me of the news and affairs of the day, in a manner perhaps not more confidential than my long acquaintance with him and long service in office justified, yet sufficiently so to warrant and even require an expression of the same wishes which I have always had on the subject of the Government, under all these circumstances, I say, I do not feel that I can any longer deprive myself of your society without thus telling you the motive from which I have done so.

I really have not the remotest guess how you and Mr Canning stand as to political arrangements, and I also know full well that I have no political influence (for I believe my office would be more desirable to any party than my vote) and it would therefore be very vexatious to me to have it supposed that because I happen to have had communications with $\mathrm{M}^{\mathbf{r}}$ Canning and not to have had any with you, I had taken a part against all my private and personal friendships and affections. I say this in utter ignorance of anything which may have passed between you and Canning, but lest anything should have passed and which you might suppose me to be aware of.

Herries told me in the House last night that he heard that I was very busy settling the Ministry. This of course was a joke, but a joke I dare say not without some original design at the bottom of it ; but, however that may be, I think it right to tell you (if you should have heard any imputation of that kind) $I^{\text {st }}$. 
that for myself I never have said anything differing from the hopes and wishes which I have often expressed to you; and $2^{\text {nd }}$, that as to others I never did more than (as I was desired) communicate to $\mathrm{M}^{\mathrm{r}} \mathrm{C}$ [anning] a message from a common friend, but I never mentioned to anyone till now that I had been charged with such a message ; that message, such as it was, was one that I think if you had known it you would not have disapproved of it. If you had no objection I should like to have told you the details of all this in conversation, but as it would be hardly possible that I could talk to you without appearing to expect some reply which might involve a disclosure of your own opinions, which I have no right and no wish to know before you think proper to declare them, I have rather chosen to write you this kind of explanation, leaving it with you to receive it as it is, or to invite me to talk it over to you, if you think any further explanation necessary or desirable now or hereafter.

One thing I think it right to add, that I never gave any human being any reason to suppose that I could guess and still less that I knew your sentiments, and that altho' I have heard things which, I suspected, were addressed to me as being supposed to have some of your confidence, I always have treated all such matters (and you know with perfect sincerity) as subjects on which you and I had no kind of communication.

[PS.] People who call on me tell me that all hope of arrangement of the present Govt is over. I cannot believe it.

(Add. MS. 40319, ff. 225-30.)

\section{Charles Arbuthnot to Robert Peel.}

Saturday night, ro p.m. [ 7 April.] -When I left your house Lord Melville begged I would call on him. I did so. He told me that he had long wished to say to you, and he now said to me, that notwithstanding his opinions on the Catholic question he never would belong to any Government which Canning might ever wish to form to the exclusion of his P[rotestan]t colleagues. He spoke to me a good deal on this subject. I told him I should see the Duke immediately and I asked whether I might tell him what he had said to me. He gave me full leave, adding that this had long been passing in his mind. It is well you should know what is passing.

(Add. MS. $4^{0} 34^{\circ}$, ff. $137-8$.) 
56 THE FORMATION OF CANNING'S MINISTRY

\section{Sir William Knighton to Earl Bathurst.}

$S^{t}$ James's Palace. Saturday, 7 April. Private.-... His Majesty desires to have the pleasure of seeing you tomorrow (Sunday) at one o'clock.

(Bathurst MSS.)

\section{Lord Chandos to the Duke of Wellington.}

Pall Mall. Monday night. [9 April.] Private.-I have the honor to inclose a letter which arrived very late this evening, together with one from $M^{r}$ Fremantle [No. 69] relative to and explanatory of the arrangements which were made between Lord Liverpool and my father at the time of his junction with the Government. . . . I feel that I should not be doing justice to my own feelings if I did not take advantage of this communication to convey to your Grace my own personal thanks for your kindness towards me, and may I be allowed again most earnestly to express the most ardent and anxious hopes, that your Grace will extend this kindness to my father as with reference to his only political object, the office of Governor General of India; by which you will gratify his feelings, do away with entirely all cause of discontent and uneasiness, and confer upon him as well as upon myself a lasting benefit, the good effect of which it is impossible your Grace can know, but which I shall to the latest hour of my existence acknowledge with the warmest feelings of gratitude and respect.

$$
\text { (Wellington MSS.) }
$$

\section{George Canning to Robert Peel.}

F.O. 9 April, $\frac{1}{2}$ p. 3. - I have this instant received a summons from the King. I will send to you the instant that I return.

6 p.m.-I am this instant returned, and shall be most happy to receive you as soon as it suits you to come here. ${ }^{1}$

$$
\text { (Add. MS. 403II, ff. 279-80.) }
$$

I The King commanded Peel to see Canning and to ask him to serve under Wellington. Canning naturally refused to do so. (Stapleton, p. 589.) 


\section{George Canning to the Earl of Eldon.}

Foreign Office. Io April, $\frac{3}{4}$ p. 5 .

My dear Lord,-Could your Lordship allow me to have the honour of waiting upon you at any hour this evening ? Ever, my dear Lord, With great respect, Your Lordship's obedient and faithful servant. ${ }^{1}$

(Harewood MSS.)

\section{The Earl of Eldon to George Canning.}

Io April.-I I have a few minutes ago received your note. I shall be ready to receive your visit, if it is not too late this evening for you to take a journey to Hamilton Place.

(Harewood MSS.)

80. Earl Bathurst to the Duke of Wellington.

Stanhope Street. Io April. Private.-Have you heard anything conclusive? My impression is that it was finally settled today at Mr Canning's audience at four o'clock. [The Duke's pencilled reply is on the same sheet: "I was just going to tell you that I knew nothing when I received the inclosed. Send it back."]

(Bathurst MSS.)

\section{8x. George Canning to Earl Bathurst.}

F.O. Io April, 6 p.m.

Dear Lord Bathurst,-I have received the King's commands to lay before his Majesty a plan of arrangements for the reconstruction of the Administration. I should be very glad of an opportunity of seeing you whenever it may suit your convenience; but in the mean time I cannot delay the assurance of my earnest wish to keep together the elements of Lord Liverpool's Governm ${ }^{t}$, and of my desire to act with them, and with yourself among them, on the principles on which that Government was conducted. I am, dear Lord Bathurst, Very sincerely yours.

(Add. MS. 4031 I, f. 287 .)

1 As Wellington complained of the tone and temper of Canning's letters of ro and II April, Canning's mode of addressing the other Cabinet Ministers is here given. 
58 THE FORMATION OF CANNING'S MINISTRY

\section{George Canning to the Earl of Westmorland.}

F.O. Io April.

Dear Lord Westmorland,--The King has been graciously pleased to recommend me to lay before his Majesty a plan of arrangement for the reconstruction of the Administration. In laying such a plan before his Majesty I should earnestly wish to be authorised to include in it all the members of Lord Liverpool's Cabinet as well as to continue to act with them upon the principles on which Lord Liverpool's Government was conducted. I should be happy either to see you, or to hear from you tomorrow as may best suit your convenience, previous to my waiting upon his Majesty. I am, dear Lord Westmorland, Yours sincerely.

(Add. MS. 403II, f. 283.)

\section{The Earl of Westmorland to George Canning.}

Grovr Square. Io April.-I have just received your letter. It will afford me the most sincere satisfaction to be included in and give my assistance in the reconstruction of the Administration in which all the members of Lord Liverpool's Cabinet are included, and to continue to act with you upon the principles on which Lord Liverpool's Government was conducted. No man however can judge how far he can beneficially serve his Majesty or the country, or maintain the principles on which Lord Liverpool's Government was conducted, nor can $I$ of course pledge myself without knowing in what shape and in what hands the principal offices are to be ultimately cast.

(Add. MS. 403II, f. 285.)

\section{George Canning to Lord Bexley.}

F.O. Io April.

Dear Lord Bexley, I have received the King's commands to submit to his Majesty a plan of arrangements for the reconstruction of the Administration. In this plan it is my wish to include all the elements of Lord Liverpool's Cabinet ; and none more than yourself -in which wish I hope I shall not be disappointed. I shall be happy either to see you, or to hear from you, as may best suit your convenience, before I wait upon his Majesty tomorrow. And I am always, dear Lord Bexley, with great regard, Very sincerely yours.

(Harewood MSS.) 


\section{THE FORMATION OF CANNING'S MINISTRY 59}

\section{Lord Bexley to George Canning.}

Io April.-We have been too long acquainted not to be mutually aware of each other's sentiments on most subjects of public importance. You know therefore how far we agree and where we differ; but I trust that a difference, which did not prevent the Administration of Lord Liverpool from being eminently useful to the country, will not prevent it from flourishing equally under yours, which I understand to be founded upon the same principles and to include the same elements.

In the hurry of business in which you must be engaged, I shall not trouble you for an interview, unless you wish for a personal explanation with me: but take for granted that you desire that I should retain my present situation, which indeed (considering the light in which you know the King regards it) I should not think myself at liberty to change without his Majesty's special commands.

Believe me to be fully sensible of the kindness of your communication, and that I am ever, my dear Sir, with great regard, sincerely yours.

(Harewood MSS.)

\section{George Canning to the Earl of Westmorland.}

F.O. II April.-I am much gratified by your Lordship's conditional consent to be included in the reconstruction of the Administration, and have not the least desire that you should pledge yourself hastily beyond what may appear discreet. But it cannot fail to strike your Lordship that, if every member of Lord Liverpool's Government, to whom letters have been addressed, or communication made, simultaneously, is each to defer his answer, until he knows the answer of all the others, no arrangement can ever be submitted to his Majesty. His Majesty, before whom I have laid your Lordship's letter, wishes that arrangement to be completed with as little delay as possible, as my writ must be moved before the adjournment.

I think it right to add that the principles of Lord Liverpool's Administration to which I yesterday alluded are, $I^{\text {st }}$ the freedom of individual action and discussion to all members of the Government, on what is called the Catholic question, without prejudice to any man's fair political pretensions on account of the opinion which he may happen to hold upon that question. $2^{\text {ndly }}$ the 
maintenance of the existing system of foreign and domestic policy; and a cordial co-operation, both in Parliament and out of doors, in its support.

PS. I am sorry to have been obliged to use any other hand than my own in transcribing this letter, but I am so hurried with business today that I could not keep it.

(Add. MS. 40311, ff. 298-9.)

\section{The Earl of Westmorland to George Canning.}

II April.-I have received your letter of this day. I am very sorry my letter should have occasioned you any delay, as I consider it was you alone who could explain.

If the members of the present Cabinet continue to form a Government upon the principles of Lord Liverpool's Government, and the chief power of the Government is in the hands of a person of Lord Liverpool's principles, I will most willingly give my best exertions with you-but if the present members of the Cabinet do not continue, and the chief office of the Government is in the hands of a person of different principles from Lord Liverpool, with very sincere regret I shall feel that my service can neither be beneficial to his Majesty or the country.

I am fully sensible of your kind consideration in your communication with me.

$$
\text { (Add. MS. 403II, f. 300.) }
$$

\section{George Canning to Lord Bexley.}

F.O. II April.-I cannot deny myself the pleasure of letting you know that I have submitted to the King your letter of yesterday, and that his Majesty expressed the greatest satisfaction at your prompt and frank acquiescence in the proposition which I was commanded to make to you. His Majesty particularly desires me to say to you that if all the elements of Lord Liverpool's Administration are not kept together, it is no fault of his Majesty's, nor of mine. His Majesty still trusts that this will be the result, but his Majesty felt the directness of your letter the more sensibly from my having to lay before his Majesty at the same time with yours, one or two answers of a less decided and explicit character.

[PS.] I shall be very glad to see you, but we shall meet at Wynn's today at dinner.

(Harewood MSS.) 


\section{THE FORMATION OF CANNING'S MINISTRY '6r}

\section{Lord Bexley to George Canning.}

Great George Street. II April.-As I shall have the pleasure of meeting you at dinner, I shall say no more in answer to your letter, than to express my satisfaction that my conduct has been honoured with his Majesty's approbation, and has appeared to you to deserve the character of frankness and candour. I felt that I owed it to the King and to you to make my answer as prompt and explicit as was consistent with the preservation of those principles and connections to which you have long known me to be attached, and from which, as I advance in years, I feel an increasing reluctance to depart. I therefore trust that all the elements of Lord Liverpool's Government will be kept together, as the best security for perseverance in that course of policy by which he so long secured the attachment and promoted the interests of the public.

(Harewood MSS.)

90. The Marquess of Londonderry to the Duke of Wellington.

Ir April. Private.-... My appointment with H.M. stands fix $^{d}$ for tomw at 3 if not changd in the morning, and if anything is settled which you can confidentially inform me of which may in some measure enable me to judge how I should steer my course concordantly with my poor brother's memory \& principles, you will forever oblige [etc.]

(Wellington MSS.)

\section{George Canning to Earl Bathurst.}

F.O. II April, 6 p.m.-It would take me more time than I can possibly find to answer your note in writing. But we shall meet at Wynn's ${ }^{1}$ - or could you call here for five minutes in your way there? I went to your office to beg to see you but you were gone.

(Bathurst MSS.)

1 According to Melville, all the Cabinet Ministers except Wellington, Peel, and possibly Eldon too, dined at Wynn's that evening. (Add. MS. 40317, f. I95. Melville to Peel, 30 April. [Part of the letter is in Parker's Peel, i. 488.$]$ ) 


\section{George Canning to the Duke of Buckingham.}

II April, I0.45 p.m.-I find upon my return home, your Grace's letter of this evening. I hope your Grace will allow me without offence, to speak frankly to your Grace in answer to it. In the position in which I am at present placed I cannot properly or honourably have any political communication which I am not at liberty to report to the King, and to impart to those of my colleagues with whom I am in daily intercourse. Your Grace will judge whether it would suit your convenience that what you may wish to say to me should be thus reported and imparted. If so, would your Grace object to make your communication to me in writing ? Otherwise $I$ must of necessity take a written memorandum of it and trouble your Grace to authenticate it: a process for which I fear it might be physically impossible for me to find time, but which the experience of some years of office (and even of the last few days) proves to me to be indispensably necessary to prevent misconception and misrecollection.

(Harewood MSS.)

\section{The Duke of Buckingham to George Canning.}

Buckingham House. I2 April. In reply to the letter dated last night which I had the honour of receiving from you, I beg to say, that as it now is universally known that you have received his Majesty's commands to form his Administration, the object which I had in view in desiring to see you, was to recall to your recollection that on a former occasion you acquiesced in the opinions of those who considered me the fittest person to succeed Lord Amherst in the Governor Generalship of India, should India be at peace when his Lordship resigned his office, and to request to know whether you are of the same opinion, now that India is at peace, [and] his Lordship has resigned his office. . . . You are the best, and must be the only judge whether you consider it worth your attention to give me the means of seeing you for five minutes on this subject.

(Harewood MSS.)

\section{George Canning to the Earl of Westmorland.}

F.O. I2 April.-On my return home yesterday evening from our dinner at Mr Wynn's, I found your Lordship's letter informing 


\section{THE FORMATION OF CANNING'S MINISTRY}

me you feel " that your services can neither be beneficial to his Majesty's service nor to the country, unless the members of the present Cabinet continue to form a Government upon the principles of Lord Liverpool's Government ; and unless the chief office of the Government is in the hands of a person of the principles of Lord Liverpool." As to the first of these conditions, I can only say that every one of the members of Lord Liverpool's Cabinet has been pressed to continue to form a part of the Government now in contemplation "upon Lord Liverpool's principles." But if by Lord Liverpool's principles-one essential part of which I always have understood to be (such as I described them to you in my letter of yesterday) free action and opinion on the Catholic question, your Lordship means that the first office of the Government is always to be in the hands of some person professing hostility to the Catholic question-that no individual shall be at the head of the Government who is of opinion that the Roman Catholic question might sooner or later be beneficially [sic]-I learn for the first time from your Lordship that such were the principles of Lord Liverpool's Government, and I absolutely deny that according to anything ever declared to me by Lord Liverpool himself to the last period of our intercourse, he at any time understood his own principles in that sense. I am sorry that the Government of which his Majesty has been graciously pleased to confide the formation to me, cannot have the benefit of your Lordship's services, and I have the honor to be [etc.]

(Add. MS. 403II, ff. 302-3.)

\section{Lord Bexley to George Canning.}

Great George Street. I2 April.-Though I hope my letters yesterday and the day before were sufficiently clear to leave no doubt that my acceptance of the proposition you so kindly made to me was to be considered as conditional on the actual preservation of all the remaining elements of Lord Liverpool's Government, yet some circumstances which I heard yesterday from Robinson make me desirous to express myself still more distinctly on this point.

From the day when you, in conjunction with the Duke of Wellington and Peel, thought it advisable to withhold the message to the Cabinet with which the King had charged you, I have forborne to inquire into matters which might concern his Majesty's private confidence with individuals, and therefore was unacquainted with 


\section{THE FORMATION OF CANNING'S MINISTRY}

the sentiments of any of our colleagues when I received your communication. I now learn that the Government is likely to lose the services of Peel. A greater loss than this would be, under any circumstances, the public could not sustain-but it is also peculiarly painful and embarrassing to those members of the Government who have agreed with him on the Catholic question. The composition of Lord Liverpool's Cabinet, as it respects that question, will be totally changed if the leading advocate of the Protestant cause in each House of Parliament is withdrawn from the Government. In the one case it must be borne, as the unavoidable result of that calamity which has been inflicted on the nation; but the addition of the other loss would virtually throw the whole weight of Government into the opposite scale. I also collect, both from your letter and from other information, that great difficulties exist in the minds of other members of the Administration who think with me on this subject, and this may of course still augment the awkwardness of my situation. I have every wish that the King may be able to arrange the Administration to his own satisfaction and that of the public, but I must desire to be considered as reserving my decision till I see how that is to be effected; and I think you will feel that it is better that we should not form an efficient connection, than be liable to see it speedily dissolved, and perhaps under circumstances less favourable to the continuance of private kindness and regard.

(Harewood MSS.)

\section{The Earl of Eldon to George Canning.}

I2 April.-As it may possibly be inconvenient that I should delay making this communication, I trouble you to state that I mean to decline being a part of the new Administration to be formed, as I now understand it is to be constituted. You are aware that my resignation is what for some time I have proposed : at Lord Liverpool's request at sometimes it was postponed, and -sometimes at his Majesty's. I cannot but resume that purpose, if an Administration is to be formed professedly indeed, but I think not in fact conformably to the principles of Lord Liverpool's Administration. Lord Liverpool and I differed from you upon a -question which we have all thought of vital importance-a difference of opinion, sincerely and honestly entertained on both sides. Without adverting to any other matters, whatever consideration 
they might or might not call for, it appears to me impossible to maintain that an Administration under a Prime Minister, sincere and zealous in resistance to a measure supposed to affect the Constitution, is really to be considered as an Administration existing upon the same principles as an Administration under a Prime Minister equally zealous and sincere in support of that measure, however the Administration as to the other component parts of it, may be formed. I am obliged to write in very great haste, and I have hardly time to express the personal respect and regard with which I am, dear Sir, [etc.]

[Endorsed: "R[eceived] same day while I was with the King."] (Harewood MSS.)

\section{George Canning to Viscount Melville.}

Foreign Office. I2 April, II p.m.-I have laid your letter before the King. His Majesty has determined to place the Duke of Clarence at the head of the Admiralty. I have seen His Royal Highness tonight, and he will receive Sir G. Cockburn and the other Lords of the Admiralty tomorrow at twelve. His Royal Highness appears very goodnaturedly disposed to retain the whole of your Board, or at least as many of them as are disposed to stay.

(Harewood MSS.)

\section{George Canning to Sir William Knighton.}

I2 April.-The Speaker declines only on account of his family: which would be prejudiced by his acceptance in a way which there are no means of remedying. ${ }^{1}$ (Stapleton MSS.)

Ibid., F.O. Io a.m. Most secret.-Here is B[exley]'s letter [No. 89] announcing his stay. I confess it alarms more than it pleases me. Pray, pray, take pains that no such large $\&$ indefinite promises as $B$. fancies himself to have received, be held out today $\mathrm{ab}^{\mathrm{t}}$ H.O.- \& Ireld especially, for I know not how they may be possible to be fulfilled. It would be better to dwell upon all that has been done, ${ }^{2}$ of which the application to the Speaker is proof

1 Raikes was therefore wrong in saying that Manners-Sutton declined office "from his feelings on the Catholic question" (Raikes, Journal, i. 89). Manners-Sutton evidently thought that his acceptance of the Home Secretaryship would destroy his prospects of a pension. See Nos. 192, 210, 226.

2 To appoint a "Protestant" Home Secretary. 
sufficient. If we are to have aid from $\mathrm{L}^{\mathrm{d}} \mathrm{L}$ [ansdowne], as I hope we may, the H.O. is almost all that remains open now that $\mathrm{B}$ [exley]'s Dutchy is shut.

I am going to Wynn's to meet the E.I. Chairs about $L^{d}$ $\mathrm{W}\left[\right.$ ellesley]. ${ }^{1}$

Ibid., F.O. 7 p.m.-This is the basest of all-for here is no reason pretended except that of prudent speculation. I'll " accelerate" him ! ${ }^{2}$ (Ann Arbor MSS.)

\section{The Marquess of Londonderry to the Duke of Wellington.}

I2 April.-In all your magnificent career you have never been so truly great in the eyes of every real friend as at the present moment, for what could you gain of reputation, credit, honor, advantage or ambition in a Cabinet subservient to $\mathrm{Mr}^{\mathbf{r}} \mathrm{C}-\mathrm{g} \&$ formed by him. The whole world would have attributed your remaining, to a mere love of office, for your commanding spirit was never formed to yield your sterling councils to a charlatan parvenu \& no one would suppose this yielding could be acceptable to you. Thus you would have been raild at as adhering to C_-g's car for the mere drudge of a Cabinet office. Had I dared to say thus much when I last saw you, I should have done so-but I thought I knew your heroick soul as well as any man \& in it I thank my God, your country \& your friends are not deceived!! The day will yet arrive for $\mathrm{y}^{\mathrm{r}}$ glorious triumph, but you have that at present of universal popularity in this measure, a possession another may in vain during his career ever hope to inspire. . . .

(Wellington MSS.)

I To meet the King's wishes for a "Protestant" Irish Government, Canning at once set on foot plans to remove Wellesley from Ireland. He interviewed the Chairman and Deputy-Chairman of the Court of Directors, and sounded them as to their willingness to appoint Wellesley Governor-General of India. But before their answer arrived (it was expected in about a week's time) Wellesley informed Canning that he was unwilling to return to India. (Wellesley Papers, ii. I53.)

2 This refers to Melville's resignation. The greater part of his letter is in Parker's Peel, but the following is there omitted : "I beg you to understand also that I have no desire unnecessarily to accelerate the period of my retirement, and that I am quite content to allow it to be regulated by your own convenience as to your official arrangements." (Add. MS. 40317, f. r98.) 


\section{roo. Lord Londonderry to Lord Conyngham.}

Holderness House, I2 April. (Copy.)-In obedience to your Lordship's communication, I waited again this day at St James's, when I was informed his Majesty could not see me but that he would be graciously pleased to send for me tomorrow or as soon as convenient. My object in addressing your Lordship is to request of your Lordship to remind his Majesty of his kind intention of granting me an audience, as I feel at this moment it is particularly important to me to see his Majesty, as connected with the situation in which I am placed. ${ }^{1}$

(Wellington MSS.)

\section{ror. Viscount Sandon's Memorandum.}

I2 April.-My father told me that after hearing of the intended resignation of the six Protestant Ministers, Canning went to the King who received him in bed-crying out, "Well, if you are not frightened, I am not. Non me aspere torreat. After this usage, if you were to present to me a list of names entirely Catholic, I should accept it, and say it was not your fault-that you had done everything in your power to avoid driving me to this extremity" (or words to that effect). "I shall send tomorrow to the Archbishop of Canterbury and the Bishop of London, and tell them that I had done everything I could, but that their friends had driven me to it." Query, will the King stick to this, when his irritation shall have subsided ? He is furious at being thus deserted by his Protestant servants when he himself has been making a great sacrifice of his own feelings in putting a Catholic at the head of affairs. Peel resigns on account of a sort of point of honour to Oxford, for which he considers that he owes his election entirely to his championship of the Protestant cause (indeed, in I825, after the House of Commons had come to a vote favourable to the Catholics, it was with great difficulty that he was persuaded by Lord Liverpool to remain in [the] Government), contrary to the advice of the King, of several of his friends, and to the wishes even of Canning he insists on resigning. The other Protestants, with more or less reluctance, in proportion as they have more or less hostility to Canning or attachment to office, think themselves obliged to follow his example. The suddenness and unexpectedness of their resolution proceeds it seems from the equal suddenness

$1 \mathrm{He}$ was a Lord of the Bedchamber. 
of the King's decision in favour of Canning, after having had long and confidential conversations with the Duke of Wellington, which did not seem likely to lead to that result. They had no time to notify their feelings on the subject to the King previously to his taking that step, and the Duke of Wellington thinks himself very ill used, as does the King too in his turn. Is it possible that this is all a trick of the Protestants concerted to expose Canning to a greater affront at last, and showing him his inability to stand by himself, and the little confidence he generally possesses?

(Sandon MSS.)

\section{George Tierney to Lord Holland.}

Thursday night [I2 April]._. . . In the political world confusion is worse confounded. Of the luminaries who once enlightened us, only five remain, viz. Harrowby, Robinson, Wynn \& Canning [sic]. There is indeed a sort of twilight still lingering about Westmoreland, but even that will soon be extinct. He does not think it decorous in him to resign till he has an opportunity of consulting Lord Lonsdale, whose opinion, as Lord Lowther has sent in his resignation, it is a great mark of circumspection in the Lord Privy Seal to doubt.

We have adjourned to the $I^{\text {st }}$ of May, and if I had carried my opposition to that measure to the length of a division I should have been in a majority. But then it would have been a majority of Tories, so it was best avoided.

How all this is to end I know not. I must however presume that Canning is confident in his master's support or he would hardly have consented to be gazetted as First Lord of the Treasury. I wish his expectations may be realized, but I confess I have great fears for the result. This grand resignation en masse is not only calculated to have effect as a coup de théatre but has many marks of being a well concerted scheme to forward the political operations of the Tories. It has united them all, and separated Peel and the D. of W[ellington] from Canning. How the new Minister is to carry on the war is beyond my comprehension, that is to say with any strength of his own. He cannot hazard a single division without an assurance of our full support. Indeed I do not see how he is to form his staff without our help, and though I now begin to think he must ask for it, I own I do not understand how it is to be obtained. Without us, I should say Canning's Administration, unless he can whistle back the Tories, cannot last through the session. 


\section{THE FORMATION OF CANNING'S MINISTRY}

I have not seen $G[r e y]$ since the resignations were announced, but I sat with him yesterday for some time, and he was in perfect good humour. I am afraid however he is under evil influence. . . .

You will observe that Canning's writ was only moved as First Lord of the Treasury. This, if he takes the office of Ch. of the $\mathrm{Ex}^{\mathrm{r}}$, before he is elected, will be of no consequence, otherwise he must have another election. ${ }^{1}$ I suppose there are doubts whether Robinson is to go up to the Lords.

(Holland House MSS.)

\section{Viscount Duncannon to Sir Robert Wilson.}

Thursday [? I2 April].- . . . Tho' we differ in some things upon this subject, I do not think we do to as great a degree as you think, for I am decidedly of opinion that Canning's Government is to be supported, if it is possible for us to do it, but I cannot go the length of saying that if a Protestant majority should be insisted on in the Cabinet, that I should think any great gain had been accomplished by merely throwing out the late Government and putting another into their place-the foundation of whose Govn ${ }^{t}$ was exactly similar to the last-but we will hope that such is not the case, as I cannot believe it possible that Canning would consent under any circumstances to be a part of a Cabinet so formed. That one may be formed with a few Protestants in it, which will give us a hope of a better system of government, I allow, and which we could support, but unless it is clearly understood how it is circumstanced in relation to that question, I do think it would be a complete dereliction of principle in Opposition to give support. Now I assure you I am not anxious to put difficulties in the way of our supporting Canning, but merely stating what I think upon it. I do not say that the C[atholic] question must be immediately forced upon them, or any step taken fto prevent their going on, if it should appear that their Government is formed on Liberal principles, but if they have allowed themselves to be pledged against a question of such importance, I cannot express any great joy at the change.

(Add. MS. 30III, ff. 270-I.)

1. Canning resigned his seat for Newport, Isle of Wight, and was returned for Seaford on 20 April. His appointment as Chancellor of the Exchequer was not gazetted until the 24 th. See No. 2 IO. 


\section{ro4. Lord Bexley to George Canning.}

I3 April.-I believe you know that the King was pleased to send for me this morning, and to honour me with a long conversation, the result of which has been to induce me to postpone at least the resolution I had taken of resigning. I was led to this change of intention first by the earnestness with which his Majesty was pleased to press me as his personal servant to remain with himsecondly by my wish to avoid the appearance of a systematic and concerted resignation; and thirdly by the intention which he announced to me of immediately taking some measures of so decided a nature as to place his own views on the Catholic subject, and the principles on which he meant his Government to be conducted with reference to it, out of all question. I cannot however too earnestly press you for his sake and your own to invite some decided friends of the Protestant cause into some of the vacant places in the Ministry, if those who have retired cannot be recalled; and this he told me had in one instance been already done. I may be allowed to add that to me it would be a justification of a decision which I cannot but feel to be questionable, though I hope I shall not have occasion to repent. . . .

(Harewood MSS.)

\section{The Earl of Westmorland to George Canning.}

I3 April. - I have received your letter of the $\mathrm{I} 2^{\text {th }}$. I am sorry such old colleagues should have such a correspondence. I do not mean to enter into a literary conflict on principles. If you refer to my first letter to you, you will observe that I asked how the principal offices were to be cast, not understanding from your letter, your proposition to be, that you were or were not, to be necessarily at the head of the Government. I never considered, nor did I insinuate that the principles of Lord Liverpool's Government were "that the chief should have particular opinions," but I had a right to consider and decide for myself, with the arrangement of the offices, and under the circumstances how far I chose to embark in a Government, with a chief holding different opinions from my own. The result on all accounts I much lament.

(Add. MS. 4031 I, f. 306.) 


\section{George Canning to the Duke of Buckingham.}

Foreign Office. I3 April.-I have been obliged to postpone my answer to your Grace's letter of yesterday, until I could find time to look back to what passed last year and the year before, in correspondence with different persons, on your Grace's application for the succession to Lord Amherst-in consequence of that passage in your Grace's letter which states that I " acquiesced in the opinions of those who considered your Grace the fittest person to succeed Lord Amherst." Having no recollection of such acquiescence on my part in such opinions as are here described, I could not, on the sudden, either affirm, or deny, a proposition-which nevertheless it appeared to me most important not to leave unnoticed. I have looked back to my correspondence of that date. I find in it no trace of such opinions as your Grace describesexcept in your Grace's letter to the King, in which you stated that Mr Wynn conceived that your Grace's replacing of Lord Amherst would be "an object of immense public advantage" : an opinion in which I was so far from " acquiescing" that I distinctly say in my memorandum to Lord Liverpool on your Grace's letter to the King, that " nothing had been said by me to imply concurrence in it." I did indeed repeatedly state my "acquiescence" in whatever Lord Liverpool and $\mathrm{Mr}^{\mathrm{r}}$ Wynn, the proper organs of the Government on that occasion, might decide, respecting your Lordship's destination to India-declaring that $I$ had no business with the selection, and assuring your Grace that I had no personal wishes to interpose to the prejudice of your Grace's pretensions. I am sorry to have to refer to transactions now long gone by ; but I cannot allow a declaration of "acquiescence" in an arrangement of which I had neither the charge nor the responsibility, to be construed into an approbation of that arrangement for all time to come. It is now my public duty which it was not at the time referred to, to take an active part in selecting a proper successor to Lord Amherst. I hope I shall not give offence to your Grace -I am sure I do not intend it, when I say, that without the smallest disrespect or disparagement to your Grace, I am of opinion that your Grace is not the "fittest" choice for the Government of India that might be made at the present moment. I mean, as I have said, no disrespect; I institute no comparisons. But I do not think I can fairly be called upon in the discharge of a public duty, of a highly responsible nature, to answer categorically to every 


\section{THE FORMATION OF CANNING'S MINISTRY}

candidate for any office, whether I do, or do not, think him the "fittest" of all men for the appointment ; and if so called upon, I do not see how I can answer such a question more directly, and at the same time less offensively, than I have answered it to your Grace.

(Harewood MSS.)

\section{I07. The Marquess of Londonderry to the Duke of Wellington.}

I3 April. Private.-As I may not have an opportunity of seeing you today, I enclose the copy of a note $I$ have written to $L^{d}$ Conyngham, to insist upon my audience to deliver my letter [No. IOo]. I would now entreat of you, let what will happen, not to think for a moment of giving up the army. This is the universal opinion, and were you to act contrary to it, it would be said, you acted more from pique than those real sentiments of honor, and regard for the interests of the country, which have guided your late proceedings. What you have done is spoken of at Whites and all over London, as noble and beyond what any one expected even of you. But remember, a friend, although an insignificant one, sometimes sees another's case, through the medium of a greater insight into the publick eye and rumor of the day, better than the individual himself, however more profound that individual's judgement may be, and rely upon it any retreat from the army would do you great mischief, and would only gratify C[annin]g. Sooner or later, a tremendous reaction must occur to mother Hun[n]'s offspring. My own feeling is that in the end the present seceders will be call'd on to frame their Gov ${ }^{t}$ and then pray think of persuading the Chancellor to take Liv[erpool's] place and get Copley Chancellor, and your other dramatis personae can not be long or difficult of arrangement, and CATHOLICKS as well as Protestants will hail your reappointment, and the great question of emancipation must be adjourned sine die under greater and more immediate embarrassments. . . .

(Wellington MSS.)

\section{I07A. Joseph Planta to Stratford Canning.}

F.O. I3 April. Private.-[Canning will probably combine the Treasury and the Chancellorship of the Exchequer. Planta is to become Secretary of the Treasury immediately.]

$$
\text { (P.R.O., F.O. 352/17.) }
$$




\section{T. G. B. Estcourt to Viscount Sidmouth.}

Boodle's. I3 April, $\frac{1}{2}$ past 4.- . . . The Duke of W[ellington] is said to have declared at $\mathrm{L}^{\mathrm{y}}$ Jersey's last night that the resignations did not arise from the Catholic question, but on account of "the man." Sir Geo. Warrender has been sitting by my side and loudly pressing upon those around that the resignation of the Ministry was solely occasioned by the King having determined to exercise his prerogative in the appointment of Canning to be his Minister, in opposition to the will of the seven Ministers who insisted that the Commander-in-Chief should be Premier. This is clearly erroneous. . . .

(Sidmouth MSS.)

109. Lord Holland to the Marquess of Lansdowne.

St. Annes Hill. I3 April. _ . . I I quite agree in all you say on these resignations. I would join no Ministry which did not distinctly espouse the Catholic cause, but I would oppose none which was formed without the Tory faction, and support any that was formed against it. But with all the manœuvres and indirect methods objected to Canning, of which I cannot quite acquit him, I suspect his adversaries are as capable of them as himself, and that cunning is the only weapon at which they can foil him. Surely Tory Ministers resigning to force the Closet is unusual and preposterous; to humour and assist it would be intelligible enough, and I fear they may have concerted this movement with headquarters. I have written to say as much as this to Grey. It is not easy to conquer his dislike and distrust of Canning, but I think he cannot be blind to the inveterate hostility which the other Party bear to our principles, to the disgrace and danger of anything like co-operation with them, and to the personal enmity to himself felt in that quarter, which they exclusively wish to precipitate and gratify....

(Bowood MSS.)

I10. The Marquess of Lansdowne to Lord Holland.

$R[$ ichmond] Hill. Friday [13 April].-I find I must be in town tomorrow for other reasons than those I mentioned to you, \& shall be able to tell you more on Monday when I hope at all events you 
will come over even if you are not able to come and stay. Desirous as I shall be of seeing you however, it would be more usefull for you just now to see $L^{d}$ Grey. I cannot understand all $I$ hear about him. One \& perhaps the only good result I look for myself in these transactions, will be a justification for withdrawing from politicks, or at least party politicks, which are now so much mixed with personal picque $\&$ passion, as to have become very disagreable to say the least of it. . . .

(Holland House MSS.)

\section{IIr. Lord Binning to Sir Charles Bagot.}

London. Good Friday [13 April].- . . . The difficulties must of course be considerable that are brought on by this new state of things-\& how they are to be got out of-one does not now seebut let the $\mathrm{K}$ [ing] \& C [anning] be stout -as I believe they both will $-\&$ depend on it the thing will do. Will he send to the Whigs or will he not? Answer that for yourself-I cannot answer it for you. He may fill up places respectably without them, but will he be secure of majorities without them? If not, is it or is it not good policy to run the risk of occasional minorities for the sake of establishing an independent Governt-looking to extraneous support after he shall have so establish'd \& carried it on independently? Now put these things into your diplomatic pipe $\&$ smoke them. Remember you may swear this-that the present state has been entirely produced by the resigners themselves. It is their own doing-no one sought for it-no one look'd for it-no one meant to force the Papists on them. They might had they thought fit have form'd a Govern ${ }^{t}$ on the basis of the last. They would not \& they alone have to answer for consequences.

I need not say I regret Melville's course. I regret it personally for him-\& on account of Scotland where there now cannot but be difficulty. With him there would I think have been nonethough his power there hath dwindled \& shrunk.

So then there is a final split between the ultra \& the moderate Tories-which with a little temper \& management on the part of the former need not have taken place. They only have done itremember that. Lamb, Dudley, Sturges Bourne are all available men-\& I would try Aberdeen-though very likely he may not be tried. This is all too early speculating.

(Bagot MSS.) 


\section{II2. The Marquess of Tavistock to Lord Holland.}

Oakeley. I3 $[$ April $]$. - . . If Canning makes overtures to you $\& \mathrm{~L}^{\mathrm{d}}$ Lansdowne, I think you sh${ }^{d}$ listen to them, provided you can do so to your own satisfaction. For my part I cannot join any Administration of which Canning is the head, but this is solely on account of my reform principles. I $\mathrm{w}^{\mathrm{d}}$ however give all the support in my power to any Gov ${ }^{t}$ of which you are a member, that is, I w look at it favourably, \& with every disposition to support it, though you must not consider me as a thick \& thin man. I $\mathrm{sh}^{d}$ be glad however to see Canning strengthened by those who have not such strong opinions on reform as I have. Moderate Whigs might without any violation of principle join him. ...

(Holland House MSS.)

\section{II3. The Duke of Rutland to Mrs. Arbuthnot.}

Belvoir Castle. I3 April.- . . I must however acknowledge the very interesting yet unpleasant letter just received from you. I have received the intelligence from another quarter respecting the virtuous retirement of those whom you have mentioned, but dear $\mathrm{M}^{\mathrm{rs}}$ Arbuthnot do not think that anything which you may ever write or say to me, with a request that it should [not] go farther, will ever depart again from my own breast. You know I dont set up for many shining qualities, but $I$ do fancy myself to be possessed of more prudence and secresy than many of my neighbours. All yesterday I kept saying that if the Chancellor \& the Duke of Wellington would shew real spirit, and resign as soon as Canning should be appointed, all might yet be well. I cannot tell you how pleased I am to hear that they have had the resolution to shew their contempt of office, when their retention of it can only be at the expence of principles publickly \& firmly professed \& acted upon. In my opinion the man who lacks consistency in public life can never be possessed of principle or probity in private life. In the present state of things I see at once the germs of a more healthy Cabinet than it has been our good fortune to have for some time past. I will never believe that $\mathrm{M}^{\mathrm{r}}$ Canning can form from his own friends \& from the ranks of the Opposition, an Administration sufficiently supported to quit even their egg shell. I cannot believe that the state of things at this moment can be pleasing to the King-who seemed most eagerly Protestant in his 


\section{THE FORMATION OF CANNING'S MINISTRY}

conversation, $\&$ who was most decided in his assurance that things should go on as they did in Ld Liverpool's, in which case he should think himself entitled to the support of the aristocracy of the country. I say that with a Catholick Premier, who has the nomination of a thousand offices, and who recommends those who succeed to the different sees as they become vacant, things cannot go on as they did in Ld L's time. I fear the Duke of W[ellington] had a chief hand in preventing $\mathrm{Mr} C$. from going to the East Indies when he was about to do so three [sic] years ago; and sorely he must rue the kindness which he then did him, if $I$ am correct in my supposition! Id Lonsdale \& I had much conversation the other day about the Duke, \& both of us were agreed as to his mind being that which is most wanted at the head of our affairs; and I repeat that I see great good in the course which he \& those who have retired with him have adopted. See the difference between Mr Pitt \& Canning. The former resigned his office because his opinion was not in conformity to that of his Sovereign on the vital question of the Catholick claims. The latter forces himself into the closest contact with his Sovereign, knowing that they are as wide as the poles asunder on that question. . . .

(Arbuthnot MSS.)

\section{II4. Lord Ellenborough to the Marquess of Lansdowne.}

Roehampton. I3 April.-I know not what may have passed since I saw you in the House yesterday, but I conclude Mr Canning must have knocked at your door, and no thanks to him for that, since, deserted by the Tories, he cannot form an Administration without you. Under these circumstances you must of course be desirous of knowing what support an Administration formed by Canning with the assistance of the Opposition would receive in the House of Lords where every vote would be of value; and I think myself bound in candour to tell you that I cannot make up my mind to support a Government of which $\mathrm{M}^{r}$ Canning is the head. I have no objection to support an Administration of which he is a member, but the preponderance in the Cabinet should in fairness belong to the Whigs by whose means alone Canning can now remain in office at all. $\mathrm{He}$ is at your mercy. Use your power generously but use it firmly and insist upon the First Lord of the Treasury being a Whig. Certainly if Canning's vanity makes him reject these terms Peel will be Minister; but when I 


\section{THE FORMATION OF CANNING'S MINISTRY}

had some conversation with you some time ago upon this subject you seemed to think that a Tory Government was preferable to one divided like the last, and you would be sure of having a most powerful Opposition. However this letter is only for the purpose of telling you that I can have no confidence in Mr Canning's Administration, but should have every disposition to support Lord Lansdowne.

(Bowood MSS.)

\section{The Marquess of Lansdowne to Lord Ellenborough.}

Richmond. Saturday morning [ $\mathrm{I}_{4}$ April].-I am obliged to you for the letter which I received yesterday, for the frankness with which you have stated your sentiments, and for your goodwill to myself personally, which I set a high value upon and hope under any circumstances to retain. I believe nothing, indeed I am sure nothing is definitely settled-but I must confess that where there was a concurrence of opinions and the means of giving effect to them, no objections of a personal nature (even if I felt any, which I do not in the present instance) would induce me to withhold a support from a Government however constituted which I might think it for the publick advantage to give. I really however do not know enough at present to determine which way my own sense of duty will lead me. Let me add, as you have alluded to a former conversation when you called here, that I stated to you a preference of a Tory to a divided Gov ${ }^{t}$ as the opinion of some others whom I respected, not adopted as my own, and that with a reference too to such a division (not a very fair one) as $L^{d}$ Liverpool's Govt had exhibited.

$$
\text { (P.R.O., G. \& D. I2/24.) }
$$

\section{II6. Lord Ellenborough's Memorandum.}

Endorsed, "My recollection of part of Lord Londonderry's Memorandum of his conversation with the King on the I3 April I827.I4 April." - . . . Hardinge tells me the 2 Archb. were sent for yesterday, that the $\mathrm{K}$. said the same thing to them. ${ }^{1}$

The King called Canning a - drug, \& bitter pill. I think the word was poisonous, \& complained bitterly of his having been

1 That is, he was bound by his Coronation Oath to resist Catholic emancipation. Most of these points are not referred to in Londonderry's Memorandum. 
$7 \dot{1}$ THE FORMATION OF CANNING'S MINISTRY

ever forced upon him, but he admitted Canning had conducted himself well towards him since.

In fact however the $\mathrm{D}$. of $\mathrm{W}$. has 30 or 40 times made up quarrels between the K. \& Canning.

The $\mathrm{K}$. is very angry with the seceders, but speaks highly of Peel, cannot understand Lord Melville's going out; said under any other circumstances he should have considered the loss of Lord L[iverpoo]l a very good thing. He was to have gone out at the end of the session.

The King induced Eldon to remain in when Canning came into office in 1822.

The note to the $\mathrm{D}$. of $\mathrm{W}$. was different from that to the others. He said it was his wish as well as his duty to the King's feelings to reconstruct the Gov. on $L^{d}$ L[iverpoo][['s] principle, \& added that it would be satisfactory to him if the D. would retain his offices. To the others he wrote more warmly, asking them to meet him \& talk over the reconstruction.

The Duke when he saw Canning last had heard Canning propose Robinson as the person under whom both could serve, to which the $\mathrm{D}$. did not disagree, only saying he thought $\mathrm{R}$. hardly of calibre enough. He had this conversation in his mind in his answer to Canning.

$$
\text { (P.R.O., G. \& D. 12/24.) }
$$

\section{II7. Sir James Macdonald to the Marquess of Lansdowne.}

Duke Street, Westminster. I4 April._.... I think upon the whole I found you today somewhat too much indisposed to make the sacrifice of personal comfort (for such certainly the acceptance of office would be to you) to public duty. It is right I should state to you that, with the exception of some crotchets of Lord Grey's which vary every hour, there seems to exist hardly any difference among those called the Opposition, of the necessity of your doing more than giving your support to a Government that should be formed without any restrictions on the Catholic question. Duncannon, backed by Lord Sefton and some of the most unlikely men, are of opinion that nineteen in twenty so think. He tells me too that the Opposition was computed by the late Ministry at 220 , but that it may be fairly taken at 200 , he having 180 on his list to write notes to. ${ }^{1}$ No slight body this to bring into any

1 Lord Duncannon was the Chief Opposition Whip. 
negotiation. Of these the most eager, perhaps, for something more than support to Canning under his present circumstances are the members for the most populous places, and the Irish membersthe latter indeed would be in perfect despair if, when all that is Orange and illiberal is arrayed against Canning, a mistrust of the man were to limit your powerful aid to a mere support. The Opposition tender you their unqualified confidence if you shall see grounds for assisting in the formation of the new Ministry. Ireland will tender you her's the moment they see you so embarked-and what if the King should mean to make Canning his dupe? May you not then prove too strong for him, or if you do not, shall you suffer for the part you have thus honestly and gallantly taken, either in public reputation or in self satisfaction? Some of the ex-ultras give out that restrictions were imposed on Canning as to the Catholic question. Binning and others at White's publicly assert that it was not so. However this may have been he could not insult you by making you any sort of proposition if they now existed-but it appears to me that to have the existence of any such restriction on the part of the King denied or disproved is all that you would be likely to require, and all that need be said on that particular subject; as to how or when that subject should be discussed, you could not make any stipulation, because you could not yourself tell, as it must depend on future contingencies.

I fairly own I dislike the situation of the parties at starting. Canning would wish to open the negotiation as First Lord of the Treasury; looking only to the interests and to the permanency of the Administration if formed I should say that it would be infinitely wiser for him to resume his late post, and that you should take the Treasury, and such I verily believe would be the opinion of three fourths of those who would be the supporters of the Ministry in both Houses. It ought not to be a question of filling up certain vacant offices, but of making as strong a Ministry as circumstances admit. Placed in the jeopardy in which Canning is with his retreat on the Tories cut off, he must not carry himself too high in a negotiation with him who is to bring him much the larger portion of his support-though you would be the last man to press this beyond what the interests of the arrangement itself demanded. I do in my conscience believe that the opportunity does exist of forming a popular and powerful Government to the utter discomfiture of the Tories ; but whether it will prove available must depend on the King's sincerity, Canning's practicability, 
and your own courage. There is a report that Canning has filled up most of the principal Departments, but I suppose this can only be provisionally, that the public service may not suffer; if otherwise, he must be mad. If the King means to carry the thing through he must be prepared to make any sacrifices of personal prejudices, and unless Canning's favour is solid enough to have enabled him to prepare the King for this, his attempt at a Ministry will fail. . . .

(Bowood MSS.)

\section{II8. Henry Hobhouse to Viscount Sidmouth.}

Whitehall. I4 April. Private.-. . . I think it best becomes me to be passive; with the intention to remain here, if the option of so doing is given to me by a principal not personally objectionable. Pray tell me fairly, whether you think this a fitting course for one who has never mixed himself with politics but minded his own business during three apprenticeships. The Ordnance is offered to $L^{d}$ Anglesey. $L^{d}$ Palm[ersto]n is afraid of vacating Cambridge, 1 but is to have a seat in the Cabinet. . . .

(Sidmouth MSS.)

\section{II9. The Earl of Carlisle to Lord Holland.}

Grosvenor Place. I4 April.-I always wish to be able to communicate to you any transaction in which I may be engaged. I have seen Canning twice lately, \& this morning by his desire I called upon Lansdowne to assure him of C.'s wish not only to obtain his support \& that of his friends, but that he should form a part of the Govt, that at present he did not correctly know the materials that were in his possession for constructing a Government, \& that therefore he could not make any distinct proposition. That in the course of the session he should know his exact position, that some of the arrangements were necessarily temporary, \& particularly instanced the foreign seals, Granville having them for a time, but not giving up the Paris Embassy.

Lansdowne seemed to think the course Canning had taken judicious, but you will see him on Monday. . . .

(Holland House MSS.)

${ }^{1}$ See Bulwer's Palmerston, i. r89. 


\section{THE FORMATION OF CANNING'S MINISTRY 8I}

120. Lord Holland to the Earl of Carlisle.

I4 Febry [a slip for April].- Many thanks, dear Carlisle, for your letter. You do not mention how the main point of the Cath ${ }^{\mathbf{k}}$ question stands- $\&$ on that I should imagine the success of every overture \& arrangement must principally depend. I dine with $\mathrm{L}$ [ansdowne] tomorrow, $\&$ am as you suppose somewhat impatient to hear details, tho' from your account I am afraid there is nothing as yet very distinct. If there is power \& will to propose a junction upon honorable terms it would I think have been, tho' in substance perhaps the same, in shape more conciliatory to invite so leading a man as L. to assist in forming rather than to form hereafter a part, in an Administration-\& if that was for some reason impossible it would perhaps have been better either to have postponed the communication or to have stated the reason for not having made it more complete \& explicit.

Arrangements avowedly temporary cannot I think succeed. To say the least of them they betray weakness \& invite attack. In the meanwhile I do most heartily rejoice at the exit of the ultra Tory intolerants-\& I smile at their shallow artifice of representing the Catholick question as having no influence on their conduct. I know at least that their return to office would be a death blow to that measure \& to all liberal policy abroad \& therefore I know it is my first wish \& duty to keep them where they are for the first time these sixty years, viz. out of power \& out of favor. Their exclusion is primâ facie evidence in favor of any Government \& entitles it to countenance $\&$ trial. But till one has means of knowing what are the intentions \& powers of the new Government upon the affairs of Ireland, I could not pledge myself to support it. If Canning is really unshackled on that point \& on the formation of a Ministry too, the postponement of all explicit overtures seems to me somewhat unintelligible. The old way of going about such a matter would have been this-Canning would have asked the King's leave to concert the means of forming a Ministry with such parties as he was willing to join \& he would then have sent to those parties to consult with them. An indistinct promise, in return for support, to admit those who give it to a share in the Government after ascertaining his own materials for constructing one (i.e. after ascertaining how far he can do without them) does not, I confess, strike me as a very prudent or gracious proceeding. However, I am always disposed to wish success to any endeavour 
which has for its object an anti-Tory \& tolerant Administration$\&$ at any rate $\mathrm{I}$ rejoice that Canning should consult you. You will I am sure, tell him that he cannot expect the support of highminded \& independent men out of office, but by the openness \& stoutness of his publick measures, \& that he cannot secure their co-operation in office but by a full concurrence of sentiment on Irish \& foreign policy \& by treating with them on a footing of equality. If he is under difficulties the best course I think is always to state quite without reserve what those difficulties are to the person with whom one thinks proper to negotiate, \& not to negotiate till one feels one can do so. Reserves \& secrets, where the real object is co-operation \& agreement, only lead to misunderstandings \& suspicions. . . .

(Castle Howard MSS.)

\section{I21. George Tierney to Lord Holland.}

Saturday [I4 April]..... [Grey] ... I have not seen but I have had a very unpleasant account of his language at Brooks'. I call it unpleasant because it always grieves me when I hear of his forgetting what he owes to his station, and indulging in ill consider'd invective. I am told he is more loud \& violent against Canning than ever, and my only consolation is that the information comes from a very prejudiced quarter. ... I certainly cannot pledge myself either to support or oppose the new Administration. I do not know the fact that it excludes the Tory faction, which with me would be a great recommendation, for it should rather seem as if $\mathrm{C}$ [anning] had to complain of having been deserted by the Tories than to boast of having dismissed them. I am however very ready to grant that a Ministry composed of persons friendly to conciliation in Ireland and liberal policy abroad, is entitled to countenance; at any rate they have a primâ facie case in their favor.

... Was there ever before an instance of a man being gazetted as Prime Minister before he had formed an Administration. This if it succeeds is all very well, but if it should end in a failure will appear ridiculous. There never was a moment in which we were called upon for so much firmness, circumspection and temper; and what remains of our character will revive or be extinguished as we conduct ourselves. The state of the country requires a Government bearing upon the face of it the appearance of stability. Take away that characteristick from the projected Administration and it can 


\section{THE FORMATION OF CANNING'S MINISTRY 83}

neither be useful to the State nor creditable to those who may compose it. God forbid that I should see the Chancellor's gang brought back again, and above all that $I$ should see it restored to power in such a way as to induce a belief that their services could not be dispensed with. Now a short lived Ministry with Canning at its head would I am afraid have just such an effect. If it be true (but of that $I$ know nothing but from report) that the King insists upon no junction being made with the Opposition, how can Canning expect to weather the storm ? Such support as we should give him for mere virtue's sake would not last to the end of the session. . . .

(Holland House MSS.)

\section{I22. Charles Wynn to George Canning.}

India Board. I4 April.-I have just received the enclosed note from Fremantle. Circumstances having interrupted all communication between the Duke of Buckingham and myself for some months past, I had no knowledge of the correspondence to which he refers.

Allow me to ask you whether it would not be highly desirable to replace one of the Civil Lords of the Admiralty by some person of more consequence and weight as a counterpoise to Cockburn, holding also the rank of Privy Councillor? I should think that you would have no difficulty in transferring either Sir George Clerk or Douglas elsewhere.

(Harewood MSS.)

\section{William Henry Fremantle to Charles Wynn.}

Stanhope Street. I4 April.-The Duke of Buckingham begged I would call upon him before he left town this morning. It was to inform me that Mr Canning had announced to him he would not recommend his Grace as a fit person to succeed to the Government of India. . . . A warm conversation arose upon this subject in which I found the Duke entertained opinions so perfectly different from mine, that I was compelled to state to him (that which you have long since known) my determination to resign my seat at Buckingham whenever his Grace called upon me to vote against the King's Government. I am anxious to make this known to you at this moment, that I may not hereafter incur the suspicion of abandoning my seat at a moment of difficulty.

(Harewood MSS.) 


\section{THE FORMATION OF CANNING'S MINISTRY}

\section{Henry Hobhouse's Diary.}

Saturday, I 4 April. ${ }^{\text {- }}$-The King came to town on the evening of the $6^{\text {th }}$, and on the succeeding days had various interviews with Canning, the D. of Wellington, Peel, the Chancellor, Ld Bathurst, the Duke of Clarence, and Ld Lauderdale. Having failed in his attempt to induce Peel to serve under Canning, he on Tuesday afternoon laid his commands on the latter to form an Administration, declaring at the same [time] his determination not to admit the claims of the Roman Catholics, saying that on this point he relied on Mr C.'s honour, and directing him to place Protestants in the offices of Home Secretary and of Viceroy of Ireld. Probably the King had from the first resolved on this step in the event of his not being able to keep his old servants together. He has laid himself under such obligations to Canning in respect to patronage that he must have excited at least great expectations in C.'s mind, and probably Sir Willm Knighton or Lady Conyngham have carried those expectations higher, and are now ready to evince their gratitude for the past by the same act $\mathrm{w}^{\mathrm{ch}}$ is to secure to themselves future favours. As soon as Canning returned from St James's, he wrote to each of his colleagues to request his continuance in the Administration. Mr Peel adhered to his determination of retiring. The Chancellor answd that his age made it fit for him to think of withdraws from public life, and that this was an apt moment for the purpose. The Duke of Welln asked who was to be at the head of the Govt, and on being informed that $\mathrm{M}^{\mathrm{r}}$ Canning himself was to be there, resigned not only his seat in the Cabinet, but the Ordnance and the command of the Army. The retirement of the Chancellor and the Duke's relinquishment of the Cabinet were not unexpected, but his abandonment of his military command was wholly unlooked for. As much so were the resignations of $L^{d}$ Bathurst, $L^{d}$ Westmorland, $L^{d}$ Bexley, and particularly of $\mathrm{L}^{\mathrm{d}}$ Melville whose opinions on the Catholic question coincide with Canning's. Id Bexley's first impression was to continue, but after three communications each expressing more doubt than the preceding, he at length resolved on withdrawing. Canning however had two reasons for wishing him to stay, notwithstanding his utter want of importance; he was the

I The following marginal note was added to this entry, on I2 May : "It has been admitted by Mr Canning that he was at this time in possession of an overture of support from Mr Brougham, Sir Rob. Wilson, and some other members of Opposition, wch he did not disclose to any of his colleagues except Mr Peel." 
only remnant of the anti-Catholic party in the Cabinet, and (what was more material) he holds the Duchy of Lancaster, an office of $\mathrm{w}^{\mathrm{ch}} \mathrm{Sir}$ W. Knighton covets a grant for life, and as Canning sees how open to observation such a grant would be, he would be reluctant to make it, and is anxious not to be driven to refuse it. 1 These secessions, accompanied by others of less importance, took Canning by surprize, and so far from being able to form an Administration so as to move for the writs on Thursday, and get the elections over during the Easter recess, the only writ moved for was his own as First $L^{d}$ of the Treasury. On this motion being made by Wynn, it was rec in the same manner as the allusion made by Tierney a fortnight ago, viz., by a loud cheer from the Opposition, faintly re-echoed from the ministerial benches. Wynn followed it up by a motion of adjournment till the first of May, $\mathrm{w}^{\mathrm{ch}}$ was faintly opposed by Tierney. The Chancellor was the only one of the seceders, who tendered his resignation personally to the King. And with him the King was extremely angry and vehement, and refused to allow him 3 weeks $w^{\text {ch }}$ he applied for to finish his decrees.

(Hadspen House MSS.)

\section{Frederick John Robinson to George Canning.}

I5 April.-The difficulties in which we are all involved are of so serious a nature, and the evils which may result to the King's service and to the country are in my opinion so formidable, that I cannot forbear putting upon paper the substance of what I stated to you yesterday respecting them. The object which has been aimed at, and in seeking which I at once concurred, was to endeavour to form

1 The following marginal note was added at this point: "Canning therefore prevailed on the King to send for $L^{d}$ Bexley and press on him his retention of the Duchy. The audience was had yesterday, and the King prevailed." [See No. I04.]

The real truth of the matter is revealed in one of Knighton's letters to Canning, dated "Monday morning ": "I think it right to mention to you that the King will not hear of the arrangement that I had proposed to you relative to the Duchy. His Majesty was violently displeased with me, and said that I had done great mischief to his (the King's views) by suggesting such a scheme ! The King's mind is constantly at work on the subject, and seems determined, at all hazards, to have the Duchy (as his Majesty terms it) in his own hands. ..." (Harewood MSS.)

This letter shows how inaccurate is the version of the affair given by Richard Bagot in a letter to his brother Sir Charles Bagot, printed in Bagot's Canning and his Friends, ii. 392. 


\section{THE FORMATION OF CANNING'S MINISTRY}

a Government, you being at the head of it, upon the principles of that of Lord Liverpool, by which, whilst any precipitate and illtimed step with respect to the Catholics would be avoided, the general policy of that Government, both foreign and domestic, might be maintained. The attempt to execute this purpose by keeping together the elements of that system, has entirely failed in consequence of the secession of so many of our former colleagues, and of the avowed hostility of various powerful interests, who have long supported the King's Government in the midst of many difficulties and dangers. It is not worth while now to enquire into the causes of that secession and that hostility; but I am convinced that the means do not exist of forming a neutral Government with any prospect of success in the result, or of satisfaction in the attempt. Can any such Government as could now be formed upon that principle be really neutral upon the Catholic question? Will not the whole preponderance of its power be in the other scale? Can we then hold out to the King an expectation that this principle of neutrality will be anything but a shadow? And can it be just to allow him to believe that neutrality exists, when we are ourselves convinced (at least I am for one) that that will not be the case ? The result then is that in my opinion such a Government cannot now be formed with any well-founded hope of success ; and I think that the King ought to be told so. As little do I see the possibility of forming a Government to which adequate support will be given (even if it were united upon the Catholic question) unless the Whigs form a part of it. General promises of support from them without office, you may depend upon it, will soon evaporate, and everything will at no distant period again be thrown into the utmost confusion. An admission of the Whigs being thus become by the mere force of circumstances, and in spite of all the efforts both of the King and of yourself, inevitable, the whole question assumes an entirely different aspect. I have no personal objection to Lord Lansdowne and to others of that party; but they are as a body so committed upon many points upon which I cannot concur with them, particularly Parliamentary Reform and questions connected with the Church in Ireland, that before I could join in Cabinet with them, I should deem it indispensable to know distinctly how far the body of the Whigs are prepared to adopt our notions upon these subjects, and whether they would require freedom of opinion and action. To the latter I could not consent. I have had enough of Cabinets divided upon one subject : and it would be almost madness to apply that principle 


\section{THE FORMATION OF CANNING'S MINISTRY}

to other questions. I lay no stress here upon the separate difficulty as between Lord Lansdowne and myself in the House of Lords, saying only that I fear it would turn out to be insuperable.

I have felt it to be my duty to repeat to you in this manner what I stated yesterday morning in conversation as my impression : and the most anxious subsequent reflection has confirmed me in what I then said. As I have never seen the King during any part of these transactions, I cannot say how far the points to which I have adverted may have occurred to his Majesty's mind; but I do conjure you for the King's sake, for your own, and for the sake of all, to look at them most seriously. You have been placed by no fault of your own in a situation of immense difficulty: but in attempting to surmount it, the utmost care must be taken not to produce other difficulties of another description, which may render the whole state of things irretrievable. Under these circumstances I am compelled to say that I consider the attempt to form a divided Government (however justifiable and even necessary it was) to have BECOME altogether impracticable. I readily concurred in it from a sense of its necessity, and persisted in it (in spite of great uneasiness and anxiety of mind) as long as I thought the object attainable : but, if an entirely new system be, in consequence of its failure, to be formed, and we are to establish new political connexions with persons hitherto opposed to us, I am sure that you will not think that I am doing anything more than what is necessary for my own vindication, and due to my own character in such a case, if I urge the indispensable necessity of some definite understanding with these connexions (be they few or many) as to the principles upon which they would be prepared to act, and I feel that I am the more enabled to seek for explanation and satisfaction upon these points, because, having no desire whatever to remain in office, a sense of duty alone has led me not to take the opportunity of Lord Liverpool's retirement to retire myself from public life.

(Harewood MSS.)

\section{George Canning to Frederick John Robinson.}

Foreign Office. I5 April, II p.m.-Planta will have apprized you (by my desire) that it is utterly, physically, impossible for me to find time, at present, to enter into written discussions upon hypothetical cases of difficulty. I can therefore only acknowledge your letter of this evening, and assure you that I do not in any degree share your 
apprehensions, and (while I do not assume to myself any right to controul the feelings or direct the course of any other person) declare my own unalterable determination not to desert the King.

(Harewood MSS. ; Add. MS. 40862, f. 208.)

\section{r27. The Earl of Carlisle to Viscount Granville.}

Devonshire House. Sunday [I5 April].-If I had found you at home I meant to have talked with you a little upon the subject of the Irish Gov't, as unless Lansdowne positively declines, it must come under discussion, and I should earnestly recommend without the intervention of third parties an interview between $C$ [anning] and $\mathrm{L}$ [ansdowne]. If there be a relaxation of principle on one side, it ought to be met with a corresponding feeling on the other. For instance, if the $L^{d}$ Lieutenant be a moderate Protestant, the Irish Secretary ought to be a moderate Catholic. Of course uncommitted persons in either situation would not come under the rule. I am much afraid that if a Protestant Ld Lieutenant were nominated, the appointment of Herries to the Irish Secretaryship would be considered as forming a substantially Protestant Gov in Ireland-for $H$. in the opinion of some persons is not considered to be the colourless person that others represent. $\mathrm{He}$ is the slave of Perceval, and was I believe to have been, if the project had succeeded, the Protestant Chancellor of the Exchequer. If $\mathrm{L}^{\mathrm{d}} \mathrm{L}$ [ansdowne] declines, this is of course waste paper; if he accepts under reserves, this subject must come under consideration. This is only for your private ear, the substance of which you may communicate to Canning, but not the note, which is too hastily written. If $\mathrm{L}^{\mathrm{d}}$ L[ansdowne] [accepts] I really think that the Irish Secretary must be a person, if not selected by him, one in whom he can repose confidence. I foresee great difficulties in either alternative that $\mathrm{L}^{d}$ $\mathrm{L}$ [ansdowne] adopts.

$$
\text { (P.R.O., G. \& D. 29/6.) }
$$

\section{Earl Bathurst to the Duke of Wellington.}

Stanhope Street. I5 April.-I send you back the letters with many thanks. Your answer to Mr Canning's second letter and your letter to the King are excellent, and no one can with any effect contend that your letter to the King was in any way disrespectful. Mr Canning's second letter was certainly intended to be offensive ; and 


\section{THE FORMATION OF CANNING'S MINISTRY 89}

clothing it with the King's sanction, made it a joint offence. All who choose to understand it, will acknowledge it to be so, but great pains will be taken to persuade the public that it was not so offensive as to require your resignation of the army. As however you in your letter coupled the two employments as Government employments, it was for the King to say that the Commander-in-Chief was not to be so consider'd.

(Wellington MSS.)

129. Sir J. W. Gordon to the Duke of Wellington.

Most confidential $\mathrm{Mem}^{m}$. I5 April.-I have been this morning endeavouring to ascertain as far as I could with propriety, from persons of influence, what the opinion is upon the recent occurrences. There is not a dissentient voice upon the act of your Grace, under the circumstances which caused it, and which appear to be known in the higher circles with tolerable accuracy.

All say that it was impossible for your Grace to submit to any indignity, and that in your station, and with your name, your personal character is in fact your public character, and a slight to the one must essentially affect the other in the transaction of your public duties. Your name carries with it obedience and respect, and if that is known to be treated with inferiority and sarcasm, the consequences would be felt sooner or later throughout your public employment. This feeling is accompanied by one of marked regretit is said - the head of the army is his well earned station-he has shewn that he knows as well to gain the public confidence by his administration of its affairs, as to command it in the field-and care should have been taken not to put such a trust to hazard by any hasty or sarcastic communication-it was placing the Duke in a painful dilemma, and he could not act otherwise than he has done. It is not sufficient answer to say, the letter had no such intentiona letter written by the King's authority, by the Prime Minister to such a man as that, ought to have but one, and an obvious meaning, and not to be liable to the construction of sarcasm and intemperance. I believe, and indeed am sure, that the above may be considered as the present opinion of those who know the case, and which must e're long influence those who do not know it.

(Wellington MSS.) 


\section{THE FORMATION OF CANNING'S MINISTRY}

\section{Lord Bexley to Viscount Sidmouth.}

Foots Cray Place. I6 April. Private.-I shall be anxious for an opportunity of talking with you upon the strange events of last week, especially as I much wish to explain to you the part I have had in them. I need not say how much I regret any appearance of separation from the D. of Wellington and Peel, and lament the loss of their services (though I hope only temporary) to the public. I had no knowledge of the intention of either of them to resign till they had actually done so ; though I had some suspicions with regard to Peel ; and it is strictly the fact, however incredible it may seem, that a great part of the mischief which has happened has arisen from want of sufficient mutual communication among the members of the Govt and with the King. For H.M. I must say that he has shown great patience and the utmost spirit of accommodation; and that it is most unfortunate that his wishes and intentions were not sufficiently known among us.

I had believed that it was generally understood among us that the frame as well as the principles of $L^{d}$ Liverpool's Govt was as far as possible to be kept together, the King selecting the head; as I concluded he had done in communication with the $\mathrm{D}$. of W[ellington], $\mathrm{L}^{\mathrm{d}}$ Bathurst, Canning and Peel, all of whom it was known he had seen. When therefore I received Canning's circular, announcing the King's authority to form a Cabinet exactly so constituted, I concluded that all was settled, and (though the arrangement was not exactly what I could have desired) I answered that I wished all success to a Govt so constituted, and should be ready to retain my situation. This was on Tuesday. On Wednesday I heard of Peel's intention to retire, though not as certain; and on that night and Thursday morning, of the D. of W[ellington]'s, Lord Bathurst's, and $\mathrm{L}^{\mathrm{d}}$ Westmoreland's. Upon this I wrote to Canning that the state of things was so totally changed that I did not see how a Govt could be formed with which I could take a part ; and that therefore it was much better we sh ${ }^{d}$ not form an official connection than run the risk of its being speedily and unpleasantly dissolved. He sent my letter, as he had done with all the others he received, to the King, who immediately wrote to me to come to him after church on Good Friday. He kept me near 3 hours complaining of the desertion of his Protestant counsellors as casting a suspicion on his principles, as well as embarrassing his measures; but professed so strong a Protestant feeling, and spoke of measures of so decided a character, 


\section{THE FORMATION OF CANNING'S MINISTRY 9r}

that it appeared to me I ought not to leave him till I could form a clearer judgement of the formation and measures of the Govt. I do indeed most seriously apprehend that, having only Catholic advocates around him, he will be gradually and perhaps unconsciously led to change his present views upon these subjects, especially if he is provoked by any conduct on the part of the Protestant interest which can be interpreted as disrespectful to the Royal authority. He ended by commanding me as his personal servant in the Duchy, not to leave him.

I am quite aware of the unpleasant situation in which I am left ; but I am the more disposed to think I have acted right from conversations $I$ have since had with $L^{d}$ Bathurst and $L^{d}$ Melville which (together with what I heard from the King) have convinced me that in this unhappy business much has been done precipitately and without due consideration. How Canning can support himself without calling in the Opposition, and how he can do that without taking a distinct Catholic ground I do not see ; but I feel that every resignation adds something to the difficulty of doing it, and that if he should be overpowered he will carry over a very formidable addition of strength to the Opposition. I believe too, that what has happened is laying a still firmer foundation for Peel's greatness, and I believe on his part unintentionally, but it will not be obtained without a very serious struggle in which it is impossible to say how much the public interests may suffer. . . .

(Sidmouth MSS.)

\section{I3I. The Earl of Carlisle to the Marquess of Lansdowne.}

Grosvenor Place. Monday [16 April].-After having communicated to Canning your disposition and wish to support where you are able to, measures of his Government, and without going into any detail whatever respecting arrangements, he of his own accord suggested the expediency of meeting you and conferring together upon some of the various matters now depending. He said that Thursday next would be more convenient to him than Wednesday, as he should then be in possession of more information. He proposed meeting you at eleven o'clock on Thursday morning at my house, as he thought that meeting at a third place would obviate remarks and reports ... I am sure that it is expedient, whatever may be the issue, that you should explain to each other your distinct views. I 


\section{THE FORMATION OF CANNING'S MINISTRY}

mentioned Lord Londonderry's conversation. He thinks it must be much misconceived and misrepresented.

(Bowood MSS.)

\section{Lord Ellenborough to the Marquess of Londonderry.}

I6 April. (Copy.) - I shall try to see Lord Grey tomorrow, but I am sure he will have seen that there are parts of your Memorandum only for your confidential friends' perusal.

I really think Lord Lansdowne having seen it, has entirely opened his eyes and arrested all negotiation.

Did I tell you, Lady Morley with her usual delicacy observed that the Privy Seal was to be divided-Warrender to take the P. and Dudley the Seal.

If the Whigs support a Government with the K[ing] Com[mander in] C[hief] and the army in commission, and a royal Duke Lord High Admiral, they unwhig themselves for ever.

(Add. MS. 40340, ff. I46-7.)

\section{J. C. Herries to Charles Arbuthnot.}

$\mathrm{G}^{t} \mathrm{Geo}$. St. I6 April.-I am come to town late and have only time to write you one line. The $\mathrm{D}$. of Clarence's appointment has certainly been an effective step and has told for the new Administration. I believe it was a scheme of Croker's. Lord Anglesea has accepted the Ordnance, which also tells. Copley jumped at the Seals, and that too has made a good impression for Canning. Tindal remains as Attorney General. Wetherall has resigned. The affair has worked hitherto more favorably than was expected. I have not yet heard of any junction with the enemy-the rubicon which $I$ cannot pass. Becket has resigned.

(Add. MS. 40340, ff. 142-3.)

\section{Lord Seaford to E. J. Littleton.}

Foreign Office. Monday, I6 April.-I am not sure that I have anything to tell you that you do not already know, certainly nothing that you will have seen in the newspapers. But as they contain more than is true, perhaps it may be satisfactory to you to know how much you may believe. Duke of Clarence, Lord High AdmiralCopley, Chancellor-Lord Anglesea (probably) Master General of 
Ordnance. ${ }^{1}$ Nothing more settled. But the delay would not justify the inference that there exist any difficulties of a nature to throw the slightest doubt on the ultimate formation of a creditable and efficient Administration.

(Hatherton MSS.)

\section{r35. Henry Brougham to Viscount Althorp.}

Monday [I6 April].-In one word, disbelieve every word you hear. All the appointments are provisional-Copley's not at all certainthe communication to Lord Lansdowne quite frank and satisfactory - Lord Londonderry's story impossible-but will be contradicted. If our friends had rather see Canning ruined than the Catholics emancipated, and rather have an ultra Government formed than one nine tenths liberal, in order to spite one man - good and wellthey have now the opportunity. But I quit them with unspeakable disgust if such be their views-and give up politics as a mixture of lunacy and imposture.

(Althorp MSS.)

\section{The Earl of Carlisle to George Canning.}

Grosvenor Place. Monday, I6 April.-Since I saw you this morning I have received a note from Agar Ellis, from which this is an extract. ... . [See No. 137.] I have written a line to Lord Lansdowne to appoint him here on Thursday at eleven o'clock, and trust he will have no difficulty in postponing his journey.

(Harewood MSS.)

\section{G. Agar Ellis to the Earl of Carlisle.}

Spring Garden. Monday [I6 April].-Not having been so fortunate as to see you today, I write one line merely to explain a message I gave Lady Carlisle for you. My meaning was shortly this -that I wished you, if you thought proper, to let $M^{x}$ Canning know from me that as an individual, \& certainly a very humble one, I am perfectly ready \& prepared to support Mr Canning's Governmentupon this ground-that a man who has broken up \& crushed the high Tory Party deserves to be supported $\&$ to be enabled to carry

${ }^{1}$ Lord Binning wrote to Littleton about the I6th saying that Anglesey was not to be in the Cabinet. (Hatherton MSS. Undated.) 


\section{THE FORMATION OF CANNING'S MINISTRY}

the work he has so happily commenced into execution. I have never been connected with any party, \& I therefore speak of course only my own feelings-but I wish to speak them now, because I think there may be some little grace in expressing them, while Canning's success is still more or less doubtful.

(Castle Howard MSS.)

\section{Lady Harriet Leveson-Gower to Charles Arbuthnot.}

Monday [16 April].-Pray thank Mrs Arbuthnot for her note. I wish she had been more explicit about the Duke's resignation. You really must write me some particulars about it. Remember I have been passing two days \& evenings with two great Canningites, i.e. Francis ${ }^{1} \& \mathrm{Mr}^{\mathrm{r}}$ Denison. Unless therefore I have some facts \& particulars to argue with them about, I shall run great risk of becoming a Canningite too which at present I am certainly not. (As it is I think I have made a very good fight of it.) Certainly as far as we know about the Duke's conduct it is not quite so satisfactory as one could wish; but he has so very sound a head that until I know the contrary I am disposed to think ignorance of circumstances $\&$ facts alone induce such a belief. He is most reprehended for having gone out, not on political grounds but on private aversion to $\mathrm{M}^{\mathrm{r}}$ Canning. Pray write me a defence of him. And is it wrong to ask you one question ? You are at liberty to answer it or not as you please. Was the Duke at any period since Lord Liverpool's illness offered the Premiership ? I sh ${ }^{d}$ like to know because the Canningites scout the idea of the possibility of his having refused it. . . .

(Arbuthnot MSS.)

\section{The Earl of Darlington to the Marquess of Lansdowne.}

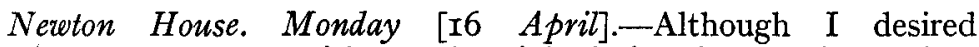
Brougham, who was with me the night before last, and hoped to reach you last night, to express very fully to yourself my sentiments and wishes at this very important moment, yet I feel anxious to repeat to you that in whatever you determine I shall be satisfied that it is most desirable, and you may be assured of my very cordial co-operation. I earnestly hope that no private animosity or personal dislike to Canning will have any such weight amongst our

${ }^{1}$ Her husband, Lord Francis Leveson-Gower. 
friends as to impede arrangements that will be so beneficial to the country, and tend so strongly to promote our general political views. If my presence be of the least possible use, I will set off on the receipt of a line by return of post ; if not, I shall be in London on Sunday evening at latest, when I hope to find some communication of the favourable termination of the new-formed Administration.

(Bowood MSS.)

\section{Earl Grey to Lord Ellenborough.}

Berkeley Square. I6 April.-I have sent to Lord Londonderry, as you desired, the very curious Minute of his conversation with the King, but unaccompanied with any letter, as I was not sure whether he was aware of your intention to communicate it to me. But for this doubt I should have expressed to him directly, what I should now wish to express to him through you, if you think it right, the pleasure I have received from reading the account of the straightforward, manly, honourable and yet respectful language which he held to the King, and the entire conviction I feel that the whole of his conduct, on this occasion, must meet with the approbation of everyone to whom it is explained. After this proof of the conditions to which $\mathrm{M}^{\mathrm{r}}$ Canning has subscribed in forming his Administration, I hope there will be an end of the unaccountable disposition manifested by too many of our friends to volunteer their support, without any security that those principles, on which they have acted, would be the rule of his Government. . . .

$$
\text { (P.R.O., G \& D. I2/24.) }
$$

\section{I41. Earl Grey to the Marquess of Lansdowne.}

Berkeley Square. I6 April.-I was very glad to receive your letter last night, having felt very foolish in hearing from all quarters that you had had a communication from Canning, and having nothing to say but that I was totally ignorant of it. That he should make an overture to you and your friends, it was natural to expect; but I confess I was not prepared for such an overture as this. What he could expect from it I cannot conceive, and your answer was certainly as civil as it could be under such circumstances. That it should be anything more was quite impossible. That he is under no restrictions I do not believe. The King in his interview with the Archbishops and with others, states distinctly that Canning has 
96 THE FORMATION OF CANNING'S MINISTRY

accepted the Government on the express condition of its being formed on the same principle as Liverpool's ; and I have reason to believe that this is confirmed, even since the resignations, in letters under Canning's own handwriting. But the solicitation to Vansittart to return for the purpose of supporting the Protestant principle in the Government, and still more the appointment of Copley, speaks a language too plain to be misunderstood. In short, to a Government constituted as, it is now clear, this must be, I can have no feeling but that of hostility. What could he mean by provisional arrangements ? Is it that some of the places occupied in the first instance by his friends, might be vacated hereafter to make way for you ? If he could mean anything like this, I should regard it as a real insult.

(Bowood MSS.)

\section{Emily, Lady Londonderry to Lord Londonderry.}

North Cray. Monday [? I6 April].-Your letter to the King is perfection. . Canning must be most gloriously mortified to find himself deserted by almost all the aristocracy of the country who do not seem to approve of the Government being in the hands of experimental philosophers. His tesselated Cabinet work will not be likely to last long. What did the King say to you ? I should [like] to see the case he made for himself-his poor lady will be in a bad way unless she silences the Press by ye pay, as all this mischief is attributed to her. ... Will Lord Dynevor be with you? Lord Sydney talks of going out. Lord Chatham will certainly be adverse to the new arrangement. I am very sorry Robinson has sold himself for a peerage. ...

(Londonderry MSS.)

\section{I43. Henry Brougham to the Marquess of Lansdowne.}

Brook's. 6 o'clock [c. I6 April].-I have stemmed the tide here aroused by that Minute of Lord Londonderry. Is it not rather like children than men to be turned in a moment by such a rumour from such a quarter and to act as our mob was really doing (Duncannon writing to Althorp and Ebrington to Tavistock to take new views of Canning \&c.) on the belief of it, without waiting twenty-four hours to ascertain its truth ? Really it is neither giving Canning nor the Catholic question fair play. But I hear it is to be contradicted this 


\section{THE FORMATION OF CANNING'S MINISTRY}

evening-this is right. Now let me entreat you to reflect well on the urgency of our situation. I dread the ultras' recovery from their very unusual fit of resignation, and if we have in the meantime been cold or thrown impediments in Canning's way, he may be driven to take them back. Only reflect on the ruin that awaits him and be merciful to him if he should be alarmed at the prospect and wish speedily to be secure any how.

\section{(Bowood MSS.)}

\section{Viscount Granville to George Canning.}

Devonshire House. I7 April. Private.-I should, I think, be acting unfairly by you, if before you commit yourself by advising the King to put into my hands for a time the seals of the Foreign Department, I did not unreservedly communicate to you the result of my own reflections upon this subject, and state to you my own estimate of my power of serving the Government in that situation. I fear that without such previous explanation, you might experience much disappointment. You must in the first place be prepared for my services in Parliament being absolutely null ; I cannot undertake to do anything in the House of Lords beyond the mere answering any question which may be put to me across the table relative to matters immediately in my department ; I could not even undertake to make a speech in explanation of, or in defence of the foreign policy of the Government, because I know from experience that such is my nervousness and painful embarrassment when I attempt to speak, that there is always a great chance of every idea which I had arranged in my head as the substance of my speech escaping my recollection, at the moment I found myself upon my legs (as was the case when I last spoke in the House of Lords), and I cannot wish the disgrace of a positive breakdown. With respect to the business of the office I have also to remind you that writing is with me a slow and laborious operation, and without any reference to the lamentable inferiority of my writing to yours, I must observe that I should be four hours writing the same quantity of despatch which you would write in one hour-when, therefore, I recollect how every moment of your day is occupied at the Foreign Office, I can scarcely conceive it possible for me to get through the necessary business. I owed it to you to state beforehand these reflections, but I assure you I have not done so with the view of shrinking from any responsibility, or from want of zeal in your-cause. If, being advised by the objections 


\section{THE FORMATION OF CANNING'S MINISTRY}

which I see to my taking the seals, you still think that by holding them temporarily, I can facilitate your future arrangements, I will do the best I can, but I think in making your fixed determination, particularly with respect to the postponement of the admission of the Whigs, you would do well to consider duly the objections I have stated, and at any rate that it will be necessary to apprize Robinson and others of your colleagues in the House of Lords that they must not look to me for any assistance in debate. ${ }^{1}$

$$
\text { (P.R.O., G. \& D. 29/8.) }
$$

\section{The Marquess of Lansdowne to the Earl of Carlisle.}

Richmond Hill. Tuesday [17 April].-There is no place where it would be more agreable to me to see any person, or transact any business than under your roof. I shall be in Grosvenor Place by eleven o'clock on Thursday. Lord Grey writes to me that he has the strongest reason to beleive that the Gov ${ }^{t}$ is formed under restrictions as to the Cath. question, which makes a direct \& explicit avowal on that point more indispensible than ever.

(Castle Howard MSS.)

\section{Earl Grey to the Marquess of Lansdowne.}

Berkeley Square. I7 April.-I have just received your note. If what was said to you on the subject of provisional arrangements was the fair result of your previous declarations, I have nothing further to observe upon it. But I had been led to consider it as a communication made to you as the leader of a great Party in the House of Lords, with a view to co-operation; and in that view I should not have thought it decent to make to you any other proposition than one in which the whole arrangement for the new Administration was left open for discussion. I must plead guilty to having made no secret of the information you sent me on Sunday; nor did the case appear to me to require any secresy. If I have erred I have at least the consolation of believing that I have betrayed no confidence and done no harm, as I had heard the communication accurately repeated by more than one person, and had expressed my opinion upon it, before I heard from you. Every new proof of your confidence will always afford me fresh pleasure, and you may be assured of my

1 A portion of this letter is quoted in my Article, The Canningite Party. (Royal Hist. Soc., Trans., Fourth Series, xvii. 2I 4.) 


\section{THE FORMATION OF CANNING'S MINISTRY}

observing your injunction with respect to any future communication you may make to me. But as it may have some influence on your wish to consult me, if a case should be foreseen in which I could be of no use by my advice or assistance, I think it necessary that you should be fully aware of my unalterable determination, if Copley is Chancellor, which I shall consider as decisive of the character of the Government, to have nothing to do with it, in any way whatever. (Bowood MSS.)

\section{Lord Seaford to Sir John Leach.}

Audley Square. I7 April. - I have reported to $\mathrm{Mr}$ Canning what you stated to me yesterday. $\mathrm{He}$ is so occupied at the present moment that it is quite impossible for him yet to fix a time for seeing you. But he requests you not to infer from his omitting to do so, that you are out of his mind, and will write to you in the course of a day or two. He desires me to add that as you had employed me to speak to him, he thought this would be the most agreeable mode of communication. ${ }^{1}$

(Harewood MSS.)

\section{Lord Francis Leveson-Gower to Charles Arbuthnot.}

Richmond. I7 April.-Harriet tells me that you are somewhat disturbed at the idea of my taking office. From what I hear the opinion seems to prevail that I shall be offered something, but as yet no such proposal has been made. I think my situation is simply this, that I have every private reason against my accepting it \& no public one, \& if any such event should take place my feelings will be anything but those of triumph or exhilaration. There is no person in the country who feels more deeply than I do the misfortune public $\&$ private of some of the late events. I had once hoped that in spite of difference of opinion on one fatal topic, I might have been able to obtain office under those to whom I look up with unlimited respect, \& under one in particular to whose invariable kindness \& condescension to myself I owe more than I can ever repay. Circumstances which I cannot controul or meddle with or judge of, have destroyed these hopes, \& I have no choice

1 The Vice-Chancellor was perturbed by a report that the office of Master of the Rolls was to be given to William Courtenay. (Harewood MSS., Lord Carlisle to Canning, [I8 April].) 


\section{IOO THE FORMATION OF CANNING'S MINISTRY}

between quitting politics altogether, \& taking my course upon purely public grounds. I declare solemnly I should prefer the former, but I do not think it fair to myself to yield to private inclinations at my time of life \& with my prospects. With my general political principles \& decided, perhaps violent, opinions on the C. question, I do not see how I can act otherwise than support the new Govt though it contains no friend of mine, as under other circumstances it would have been necessary for me to oppose that which contained every friend I had. But any one would do me much wrong who should suppose that I took this course with a light heart, or that I could for a moment forget all the causes for bitter regret $\&$ disappointment which I find in the events of the day. If there is anyone in the present Cabinet to whom I should wish to attach myself $\&$ whose motions I should be inclined to watch as a guide in some measure to my own, it would certainly be Robinson. I have little private acquaintance with him, but happen to know that he is well inclined to me, \& I think from some parts of your letters, that there is some unison of feeling between him \& myself on the present dismal state of things. I must repeat that I have no reason except common report to suppose that anything will be offered to me, $\&$ if it is a $\mathbf{L}^{\mathbf{p}}$ of the Treasury would probably be the outside, \& I am very doubtfull whether that would answer my purpose, which is of course to obtain practice $\&$ information \& not salary.

PS. Since writing this letter I have received one from Ashley which coolly informs me that he understands I am warm agst the D. of Wellington. I have written him a trimmer for beleiving anything so utterly scandalous. I do not know two consecutive particulars of the Duke's resignation, \& I should hardly have thought Ashley would have beleived me likely to prejudge the case agst him. In general I care as little as anyone what the world says but if I thought that the Duke or any of his friends except Ashley could beleive this, I only know one means left of disproving it, that of quitting the whole thing altogether.

(Arbuthnot MSS.)

\section{I49. Lady Harriet Leveson-Gower to Charles Arbuthnot.}

Richmond. Tuesday [I7 April].-. . . I I disagree with you as to thinking that it would have been fair for you to express the disgust you feel at the conduct of those who are come into power. 


\section{THE FORMATION OF CANNING'S MINISTRY IOI}

On the contrary, I think it would be a friendly thing on your part to put us in possession of as many facts as possible that we might be at any rate acting with our eyes open sh ${ }^{d}$ any offer of office be made. Remember as yet we know but one story ; we are ignorant of what has passed between the former \& the present Administration. We have heard much to the disadvantage of the former, \& much to the credit of the latter. We are therefore not unprejudiced judges. I can't say how much obliged to you I shd be to be put in possession of the case for the anti-Canning side, that I may be enabled to form an unbiassed opinion about it all. I am so well disposed for your side, so unwilling to believe the Duke can have acted foolishly, that a word will turn the scale with me. Let me intreat you then to write to me as soon as you have leisure. . . .

(Arbuthnot MSS.)

\section{The Marquess of Londonderry to the Duke of Wellington.}

[I7 April.] Private. - Tierney told me at this door today, there was no chance of any approximation with the Whigs. He said Brougham knew nothing of any overture to Lord Darlington and that it would not take if made. I hear of no new appointment; this morning it is reported Sir N. Tyndale is Atty Gen ${ }^{1}$ and Scarlett Solicitor. Wallace positively refused a peerage and Home Department. I send you a note from Anglesey to me. I wrote a strong answer, that if the die was not irretrievably cast, I would see him. If it was, there was no use in our discussions. He wrote in answer. "That I did not know the grounds he stood on or the course he meant to pursue, and that he had undertaken the office at the express command of the King." Of course, this short explicit answer has prevented my seeing him. I hope it will be well consider'd how our friends are to act. I dread the prevailing report that Peele will not oppose Canning, being of much mischief to us. The D. of Newcastle was with me today and strongly wishes for some general understanding. The $\mathrm{D}$. of Rutland means to write to you. ... . Dukedoms are flying but no Protestants to hold office can be got. Anglesey is a sad exhibition of defection, $\mathrm{f}^{\mathrm{m}}$ such a cause, and when overset, they will fall like Lucifer, never to rise again. Command me as Hardinge is out of town if I can be of the least use. Ellenborough will be a capital weapon. $\mathrm{He}$ is bitter as gaul.

(Wellington MSS.) 


\section{IO2 THE FORMATION OF CANNING'S MINISTRY}

\section{I5I. Lord Londonderry to Emily, Lady Londonderry.}

I7 April.

My drst $\mathrm{L}^{\mathrm{y}} \mathrm{L}$ [ondonderry], - I will send you as soon as I possibly can my Minute of my interview with the $\mathrm{K}$. as well as my correspondence with Robinson. They are at present in circulation and I do all the good I can to the charlatan and the quack doctor accoucheur ${ }^{1}$ in a quiet way. I wish it were possible that you could without inconvenience turn to the papers, etc. which contain the details of the base intrigue that led to the meeting. ${ }^{2}$ I want to refresh my memory on this head as I am often questioned about it, and I know not where or how to get information. Let me know if you can do this, or give me any clue. . . . I hope Tom Wood will not be cajoled by the Lord High Admiral. I tremble about Lord Hertford. But let him think of his mother, and act the part of a man. God bless you. Things upon the whole look well for he can not get the Whigs.

(Londonderry Papers. Typescript copy.)

\section{I52. Emily, Lady Londonderry to Lord Londonderry.}

St. James's Square. [c. I7 April.] _ . . I I came to town last night and am just going to Cray. Two of the most important letters you wish for are there. I will bring them to you and hope also to get the rest and most particularly a letter to the King upon the resignations that took place in consequence of C[anning]'s conduct [in I809].

I think our affairs go on prosperously. I trust Lord Hertford will be firm. I saw Ward two days ago; he is safe and he thinks Lord C. will be so also. Don't forget the papers you promised me. ...

$$
\text { (Londonderry MSS.) }
$$

\section{The Earl of Clancarty to the Marquess of Londonderry.}

Garbally. I7 April. - ... What a hash has been made of public affairs! And what a blessed prospect presents itself to our view! Will England bear an Administration thus formed by Lacklanders, and Lacklanders too who neither in their principles

1 Canning and Knighton.

2 The duel between Canning and Castlereagh in I8og. 


\section{THE FORMATION OF CANNING'S MINISTRY I03}

or conduct, have passed through their bygone public life with all the purity, formerly expected from British Ministers? I wish I could have seen the correspondence to which you allude of that archschemer C[anning] and the D. of W.-its malignant insolence I cannot conceive-it would indeed be difficult to conceive upon what in the D.'s conduct it could base itself. I should hope however that the $\mathrm{D}$. has established, and prior to his resignation of the Command-in-Chief, that an address of this kind was actually (as avowedly it seems to have been) the result of H.M.'s commands. How can the $\mathrm{D}$. of Clarence go to the Admiralty? Is the heir presumptive to the throne to be melted into one of the Lords Commissioners for executing the office of Lord High Admiral ?impossible. Is he, as stated by several of the journals, to be Lord High Admiral? If so, the other Lords cease to exist, and if to be re-inlisted as a Board of Council-must vacate their seats at all events-nay, and without a special Act of Parliament will not be qualified for seats in the $\mathrm{H}$. of Commons. Morley I suppose we shall have here-a proper representative of his Sovereign!! 1 Fortunately for us we cannot be here worse off than we have been for the last five years. Upon the Popish question, how long will $\mathrm{C}$ [annin]g keep true to any pledge he may have given ?-just as long as it may suit with his own convenience-and not one moment longer. Upon this subject I wish you would read a late pamphlet of $\mathrm{D}^{\mathrm{r}}$ Philpot, in a latter addressed to $\mathrm{C}$ [annin]g. In it is a strong and well merited éloge of your late dear and able brother, by which his constitutional view of the R.C. question is placed in strong contrast with $\mathrm{C}$ [annin]g's utter disregard of all his previous pledges in defence of the Church and Protestant establishments, civil and ecclesiastical. I could have wished that Robinson had acted otherwise than he has done-but must own I should scarcely have expected him to have done so. He has long since been in C[annin]g's pocket. That Lansdowne should have been furious at the offer to him I can well imagine. It seems impossible for the Whigs in the Lords to place themselves under Lord Robinson's bannerLord Grey, La Holland, etc. !! Where it is to end, it would be impossible to foresee-we must hope-with immediate discomfiture. God send us a good deliverance. I sincerely rejoice that you are now intirely free from it all. And permit me also to rejoice that $I$ am at a sufficient distance from it. I see, and with

1 For Lord Morley's readiness to accept the Netherlands Embassy, see Royal Hist. Soc., Trans., Fourth Series, xvii. 2 ro. 


\section{I04 THE FORMATION OF CANNING'S MINISTRY}

pleasure, that the $\mathrm{D}$. of Dorset, and the Montroses have also resigned their Household offices... . .

(Wellington MSS.)

\section{The Duke of Newcastle to Lord Londonderry.}

Portman Square. Tuesday night, 77 April. (Copy.)-If it is not giving you too much trouble, will you be so kind as to favor me with the substance of what H.M. was pleased to say, respecting me and "other noble Lords," in consequence of what passed, in my interview with H.M. You may depend upon my making no improper use of this information-but when a man is attacked behind his back, he ought to know what is said of him. If the King retained inviolably what passed between him and others confidentially, then would those others be bound to keep secret all that had passed, on such occasions-but as it is H.M.'s practice to play off against the various persons with whom he is concerned, the acts or words of those who have previously communicated with him, I am of opinion that there are cases in which it is not only justifiable, but even necessary, for a person's own honor and credit, to counteract erroneous statements by a correct statement of their own, and what has passed on certain occasions. This, I think, applies to your case, and the more, as the King sent for you. If you had forced yourself upon the King, as I did, then you would probably have done, as I thought myself bound to do, under the particular circumstances, but which now will bind me no longer. The more I reflect upon what has passed, and is passing, the more I feel the absolute and imperious necessity of not losing an instant, in liberating the King and the country from the most degrading and mischievous state, into which both have most lamentably fallen.

(Wellington MSS.)

\section{James Abercromby to Viscount Althorp.}

[April.]-Things have taken a very unlooked for turn since we met or corresponded. I never contemplated the possibility of such an enterprise as that in which Canning is engaged. I looked only to his resignation and leaving the Protestants to their own resources. If that had happened, things would have been on their old footing. The Catholic question would have been the prize for which we 


\section{THE FORMATION OF CANNING'S MINISTRY IO5}

fought, and success would have procured that benefit for the country. Now Canning is Minister, with power to advance the question by making friends for it, we should probably in another Session succeed in the Commons, and upon that possibly something might be done. But that is uncertain. The Tories are broken, far more effectually than if they had been routed in open battle. The young ones will attach themselves to Canning-they will be liberalised, and so we shall have a portion of the rank and property in the State taught to adapt themselves in a greater degree to the spirit of the age. This I look upon to be one of the greatest benefits to accrue from what is now passing. But if Canning breaks down and fails from want of support, the old Tories will resume what they consider as their inheritance, and of which they will think that they are never again to be dispossessed. They would rule us with a rod of iron. The crisis would be accelerated by the violence and bad feeling it would create. . . . We ought to consider Eldon and Wellington as our natural enemies and ought to support anybody who will keep them out-we owe at least as much as that to the man who has broken and ousted such a band of intolerant, selfish and prejudiced politicians. So far I think is quite clear. You will hear of a strange conversation between the King and Lord Londonderry. It can only be assertion against assertion until we see the Cabinet. That the Cabinet will be essentially Catholic I do not doubt. That the Catholics will be great gainers by the change I think is clear. Whether they will gain all that is really practicable is the essential question. I am inclined to believe that they will, and for this reason. I am very sure that the King is at this time really quite hostile to them, and to make a point of carrying that question at once or going out upon it, would only have the effect of re-establishing the old Tories. Then comes the question, is it fair and just to yield to circumstances, or is it necessary to attempt to form your opinions with a certainty of failure. That is a practical question, and I think can only be solved thus. If you make a clear and intelligible agreement with those with whom you are to co-operate as to the general outline of your plan, and think that you can depend on the sincerity of your allies, you do all that circumstances admit, and more is not in your power. Of that you can only judge from the details and the facts as they shall appear, and of that I am not in a condition to say much. Except only that as far as I see, Canning appears to intend that which is right. ... 


\section{I06 THE FORMATION OF CANNING'S MINISTRY}

All I wish to say is, that in my judgment, the position in which Canning has placed himself is one which imposes new and unexpected duties on those who have in an unlooked-for way, been relieved from the pressure of the old Tory gang. It is a precious moment, and the. Whigs will incur serious responsibility if they throw the country back into the hands of those whom we have so long but so unsuccessfully opposed. Lord Grey as usual is violent, ill tempered and influenced wholly by personal feelings and not at all by public principle. The means by which he seeks to run down Canning are such as I should expect from a more prejudiced and less gentlemanlike Tory than Westmorland. I am no defender of the life and character of Canning, but I should scorn to depreciate him or any other man by vilifying his parentage and reproaching him with the frailties of his mother. To the honour of Opposition, I have found no one person who does not express their total disapprobation of such vulgar abuse. Lord Grey says he wishes to go to India, and I am so shocked with the vulgarity of his tone that I am almost disposed to wish him a prosperous voyage in the terms which Eldon applied to Canning on a similar occasion.

Lady Melville forced her husband to resign. Now that he has done it and she repents, she reproaches him with his obedience to her will.

(Althorp MSS.)

\section{I56. J. W. Croker to George Canning.}

I7 April. Private.-If you should be in difficulty about a Clerk of the Ordnance (as I heard surmized today in your room) I have no doubt that Sir George Clerk would go there if you wished. If possible it would be better to make no change here, and Sir Edward Owen is a very good man of business, and with him in one of the other offices you might do with a less talkative Clerk of the Ordnance.

(Croker MSS.)

I57. J. W. Croker to Viscount Lowther.

I7 April. - . . The ministerial arrangements are going on : plenty of subordinate Tories ready to join, but Canning (and his Majesty as I hear also) is very anxious to have a Protestant 


\section{THE FORMATION OF CANNING'S MINISTRY ro7}

Secretary of State for the Home Department. This, I think, is a good proof of his desire to act on Lord Liverpool's principles, and if he is at last obliged to put a Catholic there, it will be not his fault but yours. Copley is very zealous for the new state of things and he cheers me with some hopes that you are not yet to be quite despaired of. I can only say that if you could join us again, it would delight me personally beyond measure. Perhaps I ought not to say re-join, as I am told that you have not actually resigned. I need not repeat what you yourself are so well aware of, and have so forcibly expressed in one of your letters, that you will be in a false position and that an opposition to the Crown can hardly be kept distinct from an opposition to Ministers. On the other hand your support would be so considerable and so important, that if you have any lurking spark of ambition it ought to be awakened at the prospect; I mean of that better sort of ambition which seeks for rise and reputation thro' service to the King and one's country.

(Croker MSS.)

\section{George Canning to Sir William Knighton.}

F.O., I8 April.-... If his Majesty continues well by God's blessing, \& if the fine weather returns-would not his Majesty show himself next week at the theatres?

(Ann Arbor MSS.)

\section{I59. J. W. Croker to George Canning.}

Admiralty. I8 April. Confidential.-As Copley wrote to Lowther last night, I think you had better keep Woods and Forests open a little longer (until tomorrow). I enclose you a letter from my noble friend which seems better humored than he was supposed to be. . .

(Harewood and Croker MSS.)

160. J. W. Croker to Robert Peel.

I8 April. Private and Confidential.-Knowing very little (and that little only in general and not from authority) of what has passed, I have been very much surprized to hear that it is said that I have played a part in the late transactions, and a part too that would have been inconsistent with the affectionate friendship which I 


\section{I08 THE FORMATION OF CANNING'S MINISTRY}

professed towards you, nor can I doubt that such reports have reached you and probably accompanied with accessories as unfounded as the main allegation. I therefore owe it to myself and hope I may add to you to clear away (as telling the truth is always sure to do) all such imputation and clouds. For this purpose I wished to have seen you and to have asked you not to speak, but to listen to me. If you see reason not to do so I submit, but you must allow me here to record two or three facts.

I. From the attack of Lord Liverpool till the $2^{d}$ of March I neither saw nor had any communication on any subject with $\mathrm{M}^{\mathrm{r}}$ Canning or any of his particular friends.

2. Between the $2^{\mathrm{d}}$ of March and the time you went down to Windsor I saw Mr Canning three or four times on the subject of Lord Hertford's Mission, but never but at Lord Hertford's own choice, and I once also at his desire saw Planta on the same subject. ${ }^{1}$ After

1 Lord Hertford was sent on a special Mission to Russia in June to invest the Tsar with the Garter. Canning offered him the Mission in the autumn of 1826 , but the change of Government made him hesitate to accept it. Croker wrote to him on 13 April : "I have given our conversation of yesterday the best consideration I could, and I own I cannot see the least reason why you should decline the Mission - on the contrary, I sincerely think that you cannot, or at least ought not, to do so. I put quite out of consideration your conduct, whatever it may be, towards $\mathbf{M}^{\mathrm{r}}$ Canning's new Administration; and, whether you may vote with him, or with the Duke, I cannot see how that can affect your visit to the Emperor. The Mission was given to you by Lord Liverpool's Government, thro' $\mathrm{M}^{\mathrm{r}}$ Canning indeed, but with the assent of his colleagues. On Lord Liverpool's illness, and before a step was taken towards an Administration, Mr Canning wrote to suggest to you that the circumstances were a little changed since you had accepted, and in order to prevent imputation or misconstruction, he put it to you whether you would have the affair then gazetted or not. It was then open to you to have said that 'doubtful who might be Minister and unwilling to hold a Mission if you should happen not to approve the arrangement of the Government, you declined the appointment, or at least declined having it made public, till the new Minister should be declared.' This, I say, was quite open to you ; it was more, it was suggested to you by $\mathrm{M}^{\mathrm{r}}$ Canning's own proceeding. You, however, thought that the Mission and the future arrangements of the Government were quite distinct, and you re-accepted it, rebus sic stantibus, and you desired it might be gazetted, in order to show that it was given and taken without any reference to what might happen as to [the] Ministry. How then can the arrangement or dis-arrangement of the Ministry affect a measure which was by your own desire gazetted, in order to avoid \& obviate all such connexion of the matters ?... Y You might satisfy the delicacy of your own mind by offering to return the favor into $\mathrm{M}^{\mathrm{r}}$ Canning's hands, if, under the new circumstances, he should wish to confide to another person. . . . But if he, either out of respect for the Emperor, or for consistency, or for any other reason, should not wish to avail himself of your offer, I hold that you are bound to execute your engage- 


\section{THE FORMATION OF CANNING'S MINISTRY}

Mr Canning had talked of the business on which we met, he generally said something of the state of affairs-always speaking most highly of you and of the Duke of Wellington, to which I answered, when at all, in generals, and never said anything but as to my general anxiety that the Government should by any means be kept together; but there was no question ever started of minor offices, except that it was implied that he was to be at the head of the Gov' and I thought at the F.O.

3. From the time you all went to Windsor, I do not know the date, $[\mathrm{I}]$ never spoke to $\mathrm{M}^{\mathbf{r}}$ Canning nor any of his particular friends except once in the House of Commons when $\mathrm{M}^{\mathrm{r}}$ Canning spoke to me for a good while, in terms of the greatest cordiality and even of obligation on his part towards you ; but nothing of politics passed from him except in that sense, nor from me except expression of my regard for and confidence in you ; and the impression this conversation left on my mind was that you were likely to stay in office with an accession of friends, confidence and power, but this was only impression, for $\mathrm{M}^{\mathbf{r}}$ Canning never mentioned to me any communications he had had with you, but only spoke in general terms of regard about you, and I only said that I looked on you and the Duke of W[ellington] as indispensable ingredients in any arrangements that should be made on [the] general principles of $L^{d} L$ [iverpool]'s Government. This I say was the only time I spoke to $\mathrm{M}^{\mathrm{r}}$ Canning until the morning of Friday last, the $13^{\text {th }}$.

4. On Wednesday the $I I^{\text {th }}$ in the evening $I$ heard a report that you had resigned. On Thursday that was confirmed to me by

ment, altho' that engagement binds you to nothing else. . . . Having thus performed my duty towards you in offering you my candid opinion on a point in which you have desired my intervention, let me give weight to that opinion by reminding you that $I$ was no advocate originally for your acceptance of the Mission; that I gave you no opinion on the re-acceptance of it ; that I neither had nor have any desire to lay you under obligations to $\mathrm{M}^{x}$ Canning ; that until I went to him lately by your desire, I had not been, I believe for two years, alone in the same room with him ; that my first political connexion was with the Duke of Wellington, and my nearest private friendship (after yourself) was Peel. I think therefore I am entitled to say that in the advice I now give you, I can have no object, no desire, but that your conduct should be clear and consistent and above all cavil. Observe that I do not mix politics with these considerations. You and $M^{r}$ Canning agreed to throw them aside when the Mission was gazetted, but altho' you may, and perhaps ought to place the favor at the re-disposal of $M^{2}$ Canning, I think that if he feels that it is for the good of the public service, and for the honor of the country that the reappointment should not be revoked, you are bound to go, and the more bound the more disagreeable it may be to you. . . ." (Croker MSS.) 


\section{IIO THE FORMATION OF CANNING'S MINISTRY}

Huskisson, whom I saw on other business, and who told me that particular with great regret and much approbation of you. I had no kind of talk with him about arrangements nor did any such ideas come into my head. During all this period I had out of delicacy refrained from speaking to you any more than to anyone else (except the conversation which $\mathrm{M}^{\mathrm{r}}$ Canning imposed, if I may use the expression, on me in the House of Commons) nor did I hear or know or suspect any particle of what was going on, and altho' from your conversations before and since Lord L[iverpool]'s attack I had reason to fear that you would take the first opportunity of leaving office, contrary hopes were excited by what I heard as well from Mr $\mathrm{C}$. himself as at dinner tables, etc., of the terms in which you spoke of each other. I therefore was not surprized tho' I was disappointed and sorry to hear of your resignation.

5. I now come to Friday last, the $3^{\text {th }}$. On coming to town that morning I found a message from $\mathrm{M}^{\mathrm{r}}$ Canning to beg me to call upon him before II o'clock. I then thought that no reserve should prevent my seeing you altho' you had not as I had begged you a few days before to do, let me know when the period for such reserve was passed by your having made a decision. I sent as soon as I received Mr C.'s message to beg to see you-you were not able to do so. While I was waiting for your answer, I found the other members of the Board discussing (on a similar invitation of which they guessed the intended purport) what we ought to do, and we all thought that we ought not to resign, at least not without our having some personal reason as to Lord Melville's successor (let me mention that Lord $\mathrm{M}$ [elville] did not acquaint me with his resignation). I received your answer declining to see me only a few minutes before the time of my appointment with $\mathrm{M}^{\mathrm{r}}$ Canning, and $\mathrm{I}$ accordingly went to him and consented to continue $\operatorname{Sec}^{\mathrm{y}}$ of the Admiralty, giving some reasons for doing so peculiar to my own views of the office, but stating that as I never had any desire to change my position for what was called the better, so now that I was about to stay in office when my dearest friend went (though he went on grounds as I understood connected solely with the Catholic question and political considerations in which I could have no share) nothing would induce me to accept anything which might seem to advance my private interests, and altho' I felt it my public duty not to resign my office, I told $\mathrm{Mr}$ Canning that if he found it necessary to his arrangements, I begged he would not hesitate a moment to remove me-that I should not be offended in any degree-that I had lately not been very comfortable in it 


\section{THE FORMATION OF CANNING'S MINISTRY III}

(which you know) and that as I held it as a public duty I was not in the least unwilling to be superseded if the public service seemed to require it. It was not until next morning, Saturday the $I 4^{\text {th }}$ that I found that I was to continue in office.

This, my dear Peel, is a succint but true and candid statement of my conduct, from the day of Lord Liverpool's seizure till the hour of my conversation with $\mathrm{Mr}$ Canning last Saturday. I have been obliged to omit numerous details which I would have stated verbally had you wished to see me, but I have not concealed anything that regarded you. I never ... . [see Parker's Peel, i. 470-I for the rest of the letter. The following PS. however is there omitted.]

[PS.] I have arranged my explanation in periods of time because I have heard it said that I was Cabinet making at a time when I had not spoke to anyone of the least power or weight on any matter connected with that subject except yourself and once with the D. of W. the morning after $\mathrm{L}^{\mathbf{d}} \mathrm{L}$ [iverpool] was attacked.

(Add. MS. 40319, ff. 239-49.)

\section{6r. The Marquess of Lansdowne to the Earl of Carlisle.}

Richmond Hill. [I8 April.]-As I may not have an opportunity of seeing you again before I go into Wiltshire, \& I propose being in town early tomorrow, I shall take my chance of finding you at home about one o'clock. I see nothing material to add upon reflection to what passed in our conversation yesterday. I have however since I saw you had a communication which implies so strong an opinion on the part of a great person on the subject of the Cath. question expressed since C[anning]'s appointment, that I should wish to state it to you. It certainly leads me to think the ground rather insecure, $\&$ that much distinct explanation must be had, before any positive step is taken.

(Castle Howard MSS.)

\section{I62. William Huskisson to John Gladstone.}

Somerset Place. I8 April. Private. (Copy.) - . . Be assured that if I had been about to accept any new situation in the Government by which my seat would have been vacated, I should have given you the earliest intimation of my intention.

But amidst all the extraordinary and unfortunate occurrences of the last ten days, I never, for one moment, entertained a thought of 


\section{II2 THE FORMATION OF CANNING'S MINISTRY}

putting my friends at Liverpool to the certain inconvenience, and possible heavy expence of my re-election. This alone would have been motive enough (unless it had been indispensable for the King's service) not to change my present office ; but I may also add, that having been much attacked for measures which I have brought forward (tho' with the sanction of all my colleagues) since I came into my present office; and attacks being still announced against those measures, I am quite determined to remain at the post so threatened, if for no other reason, because it is threatened. . . . Mr Canning continues wonderfully well amidst all the unaccountable difficulties which have occurred to prevent his executing the King's commands to form a new Administration in the manner which would have been most agreable to himself as well as to his Majesty-I mean by retaining all those who had served together in council under Lord Liverpool's Administration.

(Add. MS. $3^{8} 749$, ff. r96-7.)

\section{I63. G. Granville Vernon to the Marquess of Lansdowne.}

I 8 April.-If the day had been tolerably fine I should have made you a visit, wishing to give you an authentic account of the interview between the King and his prelates of Canterbury and London. It occurred to me that a knowledge of this might not be useless to you in your present position, because you may hardly be sufficiently aware of the real difficulties which oppose themselves to Canning's endeavour to form a Government advantageously for the Irish question. The Archbishop of Canterbury came here yesterday to inform my father ${ }^{1}$ that the King sent for him on Saturday and desired him to bring the Bishop of London with him. They were near six hours with the King, who talked incessantly on the Catholic question and the conduct of the seceders. He assured them that he was as sincere and determined in his opposition to it as his father had been, and that he should always remain so - that he might tell the Bishops so, and that therefore they need not scruple to support the new Administration-that he would have a Protestant Lord Lieutenant, Secretary, and Chancellor in Ireland-that Mr Fox knew his opinion on this subject perfectly, but had advised him not to declare it unnecessarily. He said that Peel and the Duke of Wellington had refused to form a Protestant Cabinet from inability to do so, and had promised to serve with Canning. The Archbishop had not an oppor-

1 The Archbishop of York. 
tunity of suggesting that they had not engaged to serve under himbut as they were already serving with him I do not wonder that the King should have misunderstood them. You will see therefore how enormous is the difficulty of any arrangement quite satisfactory to you when the King is in this state of mind, and the immense importance of enabling Canning to succeed if possible in giving Ireland a fit Government. If he fails, the Tories will resume their influence, and if they choose to appeal to the people on the Catholic question, I fear they may be much strengthened. I wished to say this to you because I know that some of your friends think it easier for Canning to force the King on this point than it is, and nothing but the greatest forbearance and political courage on your part, in disregarding imputation, I mean, can give us a chance of a good Government. Personally I am very little concerned in the result. If I had wished for office I need not have supported Government for twelve years without it-indeed under present circumstances it could scarcely be worth my while to risk another contest at Lichfield. If I had differed from Lord Stafford in $\mathrm{I}^{\mathrm{I}} \mathrm{I} 5$ with respect to the politics of that day, I might probably have been enabled to take then the course of personal connection with you, which was always most suited to my inclination, and the impossibility of which, at that time, disinclined me from all active interference. Had my political destiny been different I should have preferred to serve under you and with you personally, to any post of more importance. Circumstances have placed others in closer relation with you, but I beg you to believe that no one has a higher esteem for you both personally and politically than [etc.].

[PS.] Since I wrote this my father tells me that the Archbishop of Canterbury told all the Bishops at dinner yesterday what I have related.

(Bowood MSS.)

\section{I64. The Duke of Devonshire to Viscount Granville.}

Wedy night [? I8 April].-Abercrombie is just come here and all that he says shews that he would be full of regret if the business should be closed before Mr Canning and Lord Lansdowne can meet. He has several things to communicate to $L^{d}$ Lansdowne on his arrival early tomorrow, and by eleven o'clock $\mathrm{L}^{\mathrm{d}} \mathrm{L}$. can call on $\mathrm{M}^{\mathrm{r}}$ Canning.

$$
\text { (P.R.O., G. \& D. 29/6.) }
$$




\section{Henry Brougham to Lord Holland.}

Guildhall. Wednesday morning [18 April]._. . . By all means come to town this morning \& fortify \& encourage $L^{d}$ L[ansdowne]. $\mathrm{He}$ is a little fainthearted. Surely our prime object is to keep out the ultras \& not let them back for the pleasure of ruining Canning. $L^{d}$ Sefton (no friend of Canning or coalitions) is full of this \& has written strongly. I send his letter to $L^{d} \mathrm{~L}$. But your firm advice is wanting to back him. I find with 2 or 3 exceptions, all our friends view things in this light, \& all my country letters, country papers, $\&$ c., shew that it is called for, \& expected that we sacrifice personality \& co-operate to make a liberal Govt, that is, if $C$ [anning] has not his head turned $\&$ is reasonable.

(Holland House MSS.)

166. The Marquess of Londonderry to Mrs. Arbuthnot.

Holdernesse House. I8 April.-We feel so unmix'd \& undivided a sentiment at the present moment, on the base venality $\&$ intrigue which has overwhelm'd the good, the honorable \& the just, that I can have no hesitation in giving you a copy, even of my secret soulthe paper you shall have as soon as I can get it copied. I think I never so truly ador'd our great hero. My letter to Robinson \& his answer will shew you. Now I prophesied to the Duke what has actually occurr'd, but the reaction will be tremendous and when C[anning] falls he'll fall like Lucifer, never to rise again.

Depend upon it, devoted hearts are never idle, but the difficulty now is, to proceed on an united course. Injudicious friends are sometimes worse than enemies, \& yet amongst ourselves there is a great apparent difference of sentiment. Peele's adherents seem to preach quiet, distant, reserv'd measures, no violent opposition. Alas, we have seen how Sidmouth flourish'd under such a regime. Some of $u$ s are for a more better course [sic.] I would hold no measure, $\&$ above all never subscribe to $\frac{1}{2}$ measures, but I am free to own my ardor of character may not be always correct. Our difficulty is this, if we prove so hot to the $\mathrm{K}$. at present, as strong measures would engender, he might feel less repugnance even to the Whigs, than to try back, for he is now plum'd by C[annin]g on his vanity \& amour propre to revenge the insults of subjects who wished to dictate. The Duke is for moderation, \& although I may differ (as I have seen H.M. so versatile, so changeable and so forgetfull) yet I have been too long commanded by a Wellington to act too decidedly against his 
opinions. In the meantime nothing in a quiet way that a faithfull $\&$ devoted heart (but alas! a secondary head) can accomplish, shall be left untried. By a skillfull dissemination of my paper through the Whigs by Ellenborough's means, I have done irreparable mischief. I think it completely \& at once open'd their eyes. The copies I enclose will shew you all this. I also send my correspondence with Anglesey. That $\mathrm{HE}$ should have so loșt himself, I deplore. I always thought him highminded, and if any dirty fellow had succeeded the Duke, I sh ${ }^{d}$ have been less unhappy, but Anglesey's last cajoling letter to me unfolds him as twofold dirty, because he thinks I will shew it to the Duke, \& that it will even on a reaction secure him the Ordnance for ever. It almost holds out he would be a spy in the enemy's camp, as what can he mean by the course he is about to pursue, when he has not only accepted but sent Vivian to replace Hardinge, MountCharles, Burgh and Gossett, Lord Fitzroy, \& all his crew, to pounce upon the office \& houses before the seceders can get their things out! What delicacy!! I have not answered the last letter, nor shall I go near this fallen soldier. All new appointments seem yet in embryo. Wallace was offer'd carte blanche, but gallantly threw up. No more Protestants I hear can be recruited. Newcastle \& Rutland are violent to the greatest degree-Hertford still uncertain, \& I fear if his mother does not save him, to be bought. I am to see Ellenborough who sees Lauderdale $\& L^{d}$ Grey today \& if anything occurs you shall hear.

[PS.] I understand my letter to Robinson has cut him more deeply than anything that has occurred. Return these 2 as I have no copy.

(Arbuthnot MSS.)

\section{r67. The Marquess of Londonderry to Mrs. Arbuthnot.}

I8 April.-My letter to the King has made quite publick talk. It is reported as insolent \& unbecoming. Pray shew it where you can as I will not be so malign'd. As to a dinner, there is no want of the will but the prudence is the question? Might I have 40 or 90 here of our good friends when St Stephen's is again in vigor. I only want a direction as to what is best. ${ }^{1}$

$70^{\prime} c^{k}$.-Pray return this. The K. has determin'd to command the army himself with a Mil. Secy. Hurrah!! I wonder how we shall go on when he cannot sometimes be approach'd for weeks \& how can

1 This and the following notes were written on the inside covers enclosing presumably the letters referred to in No. 166. 


\section{II6 THE FORMATION OF CANNING'S MINISTRY}

a Mil. Secy be between H.M. \& the Secy at War, I foster this idea at the Horse Guards, as it is more easy for the Duke's return than if we had a royal Duke. I just learn H.M. is so furious at resignations \& refusals he swears he will give up the Catholick question rather than be separated from C[annin]g.

(Arbuthnot MSS.)

\section{I68. The Marquess of Londonderry to the Duke of Wellington.}

I8 April.-Upon receiving the enclosed [No. I54], I could have no difficulty in sending the Duke of Newcastle my thanks. I agree so perfectly in all he says, we really must not be too nice. I fear that $\mathrm{d}-\mathrm{d}$ old uncle of mine "Camden" [sic] and Farnborough are gaping for bribes—the former says he must see $\mathrm{C} \_\mathrm{g}$ proh pudor !! Remember $\mathrm{C}-\mathrm{g}$ 's conduct to him. ...

(Wellington MSS.)

\section{Lady Harriet Leveson-Gower to Charles Arbuthnot.}

[c. I8 April.]-Many many thanks indeed for your interesting letter. It is really very kind of you to write to me all these details which are certainly interesting to the last degree. You may be sure I will not mention to a creature even that I have heard from you on the subject. It is all a very strange story $\&$ it is lamentable to conceive that we should be governed by so astonishingly weak a personage as his Majesty. I shd imagine he has however got a slippery piece of goods to deal with. Surely the Duke cannot be right in having thrown up the command of the army? . . .

(Arbuthnot MSS.)

170. Lord Holland to the Marquess of Lansdowne.

[c. I 8 April.]-The more I think over the subject of our late conversation and apply the comment of subsequent events to it, the more I am inclined to inculcate the greatest possible circumspection. The appointment of Copley, of Bexley, the language in the highest quarter to Londonderry and others, and the conference with the Bishops, all bear a very discouraging aspect. It looks as if Canning's authority were limited to forming a Ministry on the principle of Liverpool's. At least it looks as if the King so understood it. If so, it is possible that the friends of the Catholics may find it prudent from fear of a worse, or from a consideration of some other merits 


\section{THE FORMATION OF CANNING'S MINISTRY}

in its policy or composition, to abstain from harassing it, but I think it would be dangerous and unjustifiable in them to engage even to support, much less to co-operate with a Government, formed with the effects and in some measure with the design of eluding their favourite measure. Unless the Ministry and the Court fully and explicitly understand one another, the former, supposing it Catholic in its wishes, would be soon brought to the very unpleasant dilemma of either disappointing themselves and their friends by the relinquishment and defeat of the measures most beneficial to the country, or of being reproached with a breach of faith by the King, who would choose to understand and certainly say he understood that it was never to be urged upon him, as his objections at the forming of the Ministry were known to be unsurmountable. I allow that patronage, and yet more a Government exclusively friendly to the measure in Ireland, would be (short of a distinct pledge and understanding) the best earnest of ultimate success, but then it is only good as such, if there is behind a stronger security either by implication or actual engagement, against the measure, it is only in appearance a step, and in reality none-and when found so makes the disappointment greater. I am sure you would wish me to tell you all I feel on this subject, and therefore do so without reserve, and am the more anxious to do so because I own when I saw you at Richmond, though I was not quite satisfied with the state of things and the indistinct nature of the overture to you, yet I had not put all the circumstances together which induce me, together with subsequent occurrences, to suspect that Canning does not himself understand or has not communicated to you, all the limitations and conditions upon which he is considered to be entrusted with the formation of a new Government. Stipulation or understanding would I think even with an unmixed Government be prudent and necessary, but with a divided one, the want of it must lead to the most unpleasant results.

(Bowood MSS.)

\section{I7r. George Canning to Sir William Knighton.}

F.O. I9 April, I0.30.-I am going to Lord Carlisle's to meet $\mathrm{L}^{\mathrm{d}}$ Lansdowne. After that interview I propose calling on Sir John Leach, who came to town last night. Thence I will wait upon his Majesty. Calcraft has been here (at his own request) to offer himself, and with office. I will keep the Chanc ${ }^{\mathbb{D}}$ of the Ex. this Session. (Harewood \& Ann Arbor MSS.) 


\section{A. G. Stapleton to J. W. Croker.}

F.O. I9 April. Private \& Confidential.-Up to four o'clock today $\mathrm{Mr}^{\mathrm{r}}$ Canning would have said, give the $\mathrm{D}$. of $\mathrm{R}$ [utland] what he wishes. At that time he heard (from what he conceives good authority) to his great surprize that his Grace had declared agst the Gov $^{t}$. This however is a thing to be inquired into.

(Croker MSS.)

\section{I73. The Marquess of Lansdowne's Memorandum.}

[I9 April].-On the I9 ${ }^{\text {th }}$ of April I met Mr Canning by his desire at Lord Carlisle's house, and conversed with him for three hours. After the first interchange of civilities had passed, he told me that before he proceeded in pursuance of an intimation previously conveyed to me, of his desire that I might be induced to join in the Administration he was about to form, he wished to put me fully into possession of his own situation and all the circumstances connected with it, and that he should do so without the slightest reserve on any part of the subject, at the risk of appearing egotistical in narrating at length much that was merely personal to himself. He began by adverting to a Minute which he knew that I had recently seen, purporting to relate to a conversation between the King and the Marquess of Londonderry at an audience asked for by the latter a few days before, of the greater part of which he might say that what was not invention, was misapprehension of what had passed. The expression more particularly of "the bitter pill which his Majesty was obliged to swallow" had been indeed applied by his Majesty not to the arrangement now contemplated, by which $\mathrm{Mr}^{\mathrm{r}}$ Canning was entrusted with the formation of a new Government, but to the period when between three and four years ago $\mathrm{M}^{\mathrm{r}}$ Canning was, by the advice of Lord Liverpool, called to the King's service. The King admitted that nothing at that time could be more disagreeable to him, and that on first being informed at Edinburgh by $\mathrm{Mr}$ Peel of Lord Londonderry's death, he had said, "I desire at all events that no alteration be made in the India arrangement " $\left(\mathrm{Mr}^{\mathrm{r}}\right.$ Canning being at that time on the point of going out as Governor General). The King's behaviour to him, though somewhat cold and distrustful at first, had some time after materially altered, and of late more especially he had received the greatest marks of apparent kindness and 


\section{THE FORMATION OF CANNING'S MINISTRY II9}

confidence, without any other exception than what arose out of his Majesty's apprehensions on the subject of the Catholic claims. The King, though more at variance in opinion with respect to his system of foreign policy to which he had formerly shown himself as strongly opposed, and most particularly on the recognition of the South American States, which he had only been able finally to carry by repeatedly offering to give up the seals. The system he was desirous of pursuing with regard to the Spanish Revolution and the invasion of that country by the French, had the same obstacles to encounter from his Majesty's disapprobation and the resistance of many of his colleagues and others in office, so much so that he knew that an intimation had been conveyed to the French Government, if not directly from some of the Cabinet, from a quarter very near to it, that they might confidently persevere in their attempt, and that not a shot should be fired to prevent it; he added that when at Paris a short time ago in conversation with M. de Villele respecting the difficulties in which that Minister found himself with respect of the military occupation of the country by the French army, he had said, "How the deuce could you ever let your troops enter that country ?" M. de Villèle answered, "And how did you contrive not to be strong enough to have prevented me as you ought?" On these subjects he had lately had very little difficulty with the King, or from the intervention of any of the Foreign Ministers, with the exception of Esterhazy, who by Metternich's instruction never missed an opportunity of suggesting the great danger in which he was placed from $\mathrm{Mr}$ Canning's opinions respecting the independence of other countries, repeated so often that the King had told him he was now completely hardened to it. The King's continued and increased apprehensions on the subject of the Catholics he attributed to the great pains that had lately been used to affect his mind upon that subject, that more particularly in almost every visit he had paid to the Duke of York during his illness, the latter had conjured him by the memory of his father and the safety of the Crown, never to give way upon that subject, so that what had certainly before been an apprehension that the Duke of York had gained a popularity by his opinion upon that subject with the mass of the community, which would give him power if the King was disposed to entertain a contrary sentiment, had now become a sincere opinion as he thought of his own, still however very much connected with the dread of unpopularity. So late as the month of November last the 


\section{I20 THE FORMATION OF CANNING'S MINISTRY}

Duke of York had, at the instigation of some persons ${ }^{1}$ (the Chancellor probably meant) sent a long reasoned paper to the King dwelling upon the mischiefs of a divided Administration, and urging that the moment was now arrived for securing the country against the danger of all innovations respecting Catholics and Corn, two subjects which by some secret sympathy had become connected in the Duke of York's mind as well as in that of some others. The King sent the paper to Lord Liverpool who communicated it to $M^{r}$ Canning together with his answer, which was a very clear and able paper, in which he explained the importance he himself attached to an alteration in the Corn Laws, without effecting which, he should not consider himself as justified in continuing to undertake the government of the country, and then proceeded to show that such was the state of opinions and of Parties, that it was impossible to form an Administration exclusively for or against the Catholics-that such a one might indeed be formed in either sense-it would last a short time, but his opinion was that the party in whose favour it was tried, whichever it was, would have the worst of it and be speedily obliged to give way to the other. This reasoning had its effect upon the King and the whole attempt failed. In February came Lord Liverpool's seizure; when it happened the King and he were both ill in bed at Brighton, and for many days could only communicate with each other by messages. At the first interview which was practicable, the King after lamenting the inconvenience to which its happening so unexpectedly exposed them both, said, "You are the fittest man to be Minister and the man I should like to appoint, but what a clamour there would be throughout the country if I made a man with your opinions about the Catholics, Minister; I should never hear the last of it." $M^{r}$ Canning told him that upon that point as connected with himself he could not presume to give an opinion, but that as his Majesty could not proceed too soon from the hopelessness of Lord Liverpool's recovery, to settle in his own mind what the new arrangement should be, whether he announced it or not, he thought it his duty without delay to apprize him that he could not retain his situation under a Government of which he was not the head, and which seemed naturally

1 One of Lord Lansdowne's more serious mis-statements. The Duke of York told Liverpool that he had not consulted or communicated with any one on that occasion, and that no one had the least idea of the step he was taking. (Yonge's Liverpool, iii. 432.) 


\section{THE FORMATION OF CANNING'S MINISTRY I2I}

to have devolved to him. That when three years ago he had been induced to abandon a lucrative situation not obtained through his Majesty's favour, no small sacrifice for a poor man to make, to re-enter his Majesty's service, he had been induced to do so by its being represented to him that the situation and authority of Lord Londonderry would without any diminution devolve upon him; that he knew that a very short time before that period it had been settled, upon Lord Liverpool's desiring to retire in consequence of some differences with his Majesty, that Lord Londonderry should succeed him as Minister, although professing the same opinions as himself respecting the Catholic claims, and he knew of nothing that had occurred in the events of his Administration that ought to deprive him of the same claim which Lord Londonderry would have had, and he therefore begged to be considered as only holding the seals till his Majesty had appointed a successor. The King immediately said that was quite impossible, and they parted. At the same interview the King said he had determined to appoint him Minister, but that to guard him against the alarm that would arise from his being a Catholic, he must undertake that it should be understood that question was no longer to be agitated, and there must be a manifest preponderance of Protestants in the Cabinet. $\mathrm{M}^{\mathrm{r}}$ Canning replied that it was not in his power to prevent the question being agitated, and that he should lose all power of serving his Majesty from loss of character, if he were not enabled when it was, to avow the same sentiments as fully and explicitly as Minister as when Secretary of State, but as his Majesty appeared to take so strong a view of that subject, he thought it his duty to tell him that he thought it was in his power, if he chose, to make a Protestant Administration, and it might possibly last for some time, but he must say that it would immediately produce a degree of irritation in Ireland and party violence here that no man could tell to what scenes of confusion and trouble it might lead. His Majesty asked whether he was confident such would be the result, and on his replying that [he] was, said that certainly was not what he was willing to encounter; that he wished to make me his Minister, but that there was no necessity of any arrangement yet, and he would confer with me as to further arrangements after I had returned to London and he had left Brighton. From that time a considerable interval elapsed before Mr Canning saw the King again. Soon after the arrival of the latter at the Cottage he had invited the Duke of Wellington there. 


\section{I22 THE FORMATION OF CANNING'S MINISTRY}

What passed between them $\mathrm{M}^{\mathrm{r}}$ Canning did not know, but understood that some doubts had been expressed by the Duke of Wellington as to the expediency of $\mathrm{M}^{\mathrm{r}}$ Canning being appointed Minister, and had been asked in consequence by the King whether it would be possible to form a Protestant Administration. Some days after, $\mathrm{M}^{\mathrm{r}}$ Canning was sent for to the Cottage to meet Lord and Lady Granville. The King told him that strong representations had been made against his appointment both by some of his colleagues and by considerable persons who supported Government. He wished $\mathrm{Mr}^{\mathrm{r}}$ Canning to consider with his colleagues whether a Protestant Peer might not be appointed First Lord of the Treasury under whom they might all serve, observing at the same time that he might keep all the power of a Minister in his hands, and quoting the example of Lord Chatham's first Administration under the Duke of Newcastle, in which however the King was wrong. $\mathrm{M}^{\mathrm{r}}$ Canning replied that there would be no difficulty in finding a Protestant Lord to be head of the Treasury, but that not one under whom they could all serve, and that he for one must then entreat his Majesty to accept his resignation, and that the time pressed, the public service was suffering, and the usual period of adjournment was approaching. Nothing definite was settled, and the next day the King sent for $\mathrm{M}^{\mathrm{r}}$ Peel, whom he asked whether he could form a Protestant Administration. Mr Peel replied in the negative and returned the same day to town. On the day before the adjournment $\mathrm{M}^{\mathrm{r}}$ Canning having understood that a written representation had been conveyed to the King, who was then just come to town, against his appointment, by several of the Cabinet Ministers signifying their intention in that case to resign, went to the King and told him the time was now come in which he must make his choice and authorize him to communicate formally to his colleagues his intention to make him his Minister, in which case the writ should be moved the next day before the adjournment, or permit him to resign. His Majesty then for the first time gave him full authority, and on his return home he wrote to each of them to intimate the commands he had received to form an Administration and to request to know if they would serve in it ? This produced the correspondence with the Duke of Wellington which had been so much talked of. $\mathrm{M}^{\mathrm{r}}$ Canning produced copies of the letters but read them very hastily, but observed that the Duke of Wellington's last letter was the only one that could properly be called offensive, and that the one first addressed by him to the 


\section{THE FORMATION OF CANNING'S MINISTRY I23}

Duke of Wellington had been marked by peculiar courtesy. On the morning of the adjournment all the resignations were sent in, but $\mathrm{M}^{\mathrm{r}}$ Peel's resignation, although coinciding in point of time with the others, was not known to his colleagues to have been intended, $\mathrm{Mr}^{\mathrm{r}}$ Peel having stated to $\mathrm{M}^{\mathrm{r}}$ Canning that he had always avoided communicating with them upon the subject, and that his wish to resign was connected solely with the peculiar situation in which he stood with respect to the Catholic question, and not from any personal indisposition to $\mathrm{M}^{\mathbf{r}}$ Canning. $\mathrm{M}^{\mathbf{r}}$ Canning here mentioned that $\mathrm{Mr}^{\mathrm{r}}$ Peel had both on the South American question and the recent demonstrations in Portugal had [sic] warmly concurred in supporting him against his other colleagues. The King spoke with great warmth and displeasure at these resignations. $\mathrm{M}^{\mathrm{r}}$ Canning observed to him, he had thought we Tories at least were of opinion that the choice of a Sovereign was not in the first instance to be interfered with, but that he wished to know whether he still should cause his writ to be moved? The King said their conduct was quite unjustifiable and that he was determined that his writ should be moved-commenting at the same time at great length on each particular case. On every occasion since, his Majesty had spoken on the subject in angry terms and expressed a readiness to all his suggestions for the formation of a new Government, expressing a wish only that the Irish Government might be Protestant. Mr Canning then proceeded to detail his reasons for immediately appointing to the Admiralty and Court of Chancery, the desire which he and his remaining and new colleagues entertained that I should take a part in the Administration, and his readiness to answer any further inquiry. It was agreed that I should communicate again with Lord Carlisle in the course of the day, and after some conversation upon the accidental difficulty created by a notice given in the House of Commons for the repeal of the Test Act, the awkward appearance of exhibiting a new Government known not to be united on one great subject, disunited also upon another, and the importance of not increasing unnecessarily the alarms of the Church, we parted for that day. ${ }^{1}$ [In Lady Lansdowne's handwriting.]

(Bowood MSS.)

1 It is clear that Lord Lansdowne confused some of the dates. 


\section{I24 THE FORMATION OF CANNING'S MINISTRY}

174. The Marquess of Lansdowne to the Earl of Carlisle.

$B$ [erkeley] Sq[uar]e. Thursday [? I9 April].-I entirely agree in your view of the [Catholic] question-it is quite essential to our present comfort \& to our future credit, that there should be no. doubt as to its being open for consideration at any time. This. must be distinctly stated tho' in a manner as respectfull \& conciliatory as possible. To ask this explanation is to ask no concession as it is in the power of his M. at any time to break up his Govt if he thinks fit to do so whether in consequence of any previous. resolve or not. There are many after considerations into which it. is not necessary now to enter \& I write in haste.

(Castle Howard MSS.)

\section{George Canning to the Earl of Carlisle.}

F.O. I9 April.-I enclose, according to our agreement, my bill of fare. I do not mention any names, but you are to understand, of course, that I am authorized to offer the Lord Chamberlainship. distinctly to the Duke of Devonshire. I also avoid mixing any observations or stipulations-but of course I understand that my opinions and views about the Catholic question, as explained to. Lord Lansdowne this morning, are the rule of the Government on that subject, individual opinion and action being left wholly free. I understand also that the question of Parliamentary Reform is. not to be brought forward, and that that of the Test Act is to be withdrawn or at least not pressed. Perhaps you had better state the substance of this letter than show the letter itself. I write in such haste that I have not time to make it less short and less. peremptory. But the substance is essential to my honour, and to. my power, and I believe to the peace of the country and the final carrying of the object that we all have in view.

I Lord Chamberlain

$$
\begin{gathered}
{[\text { Enclosure. }]} \\
\text { House of Lords. }
\end{gathered}
$$

2 Lord Privy Seal

3 Secretary of State for the Home Department

House of Commons.

4 One Cabinet office

5, 6. Two Privy Councillor's offices 


\section{THE FORMATION OF CANNING'S MINISTRY 125}

7 One Under Secretary of State

8 One Board office

Law.

9 Attorney or Solicitor General, according to the arrangement that may be found practicable, and to the person proposed.

(Harewood MSS.)

\section{I76. George Canning to F. J. Robinson.}

F.O. Ig April, 9 p.m.-I returned about three hours ago, from a day of such fatigue (in talk) that I really could not, either write or send to you. I have settled with the King that we are to be with his Majesty at two tomorrow to give up and receive the Exchequer seal. Peel we thought it best to put off till Monday in the hope that the permanent holder would be then ready to receive it. I cannot in one word answer your question about Lord Lansdowne. I have heard since he and I parted indirectly his report to his friends, than which nothing could be more fair and even flattering. Brougham, I understood, instantly declared for junction. But others thought more consultation necessary. I shall perhaps hear more tonight, and I will see you as early as you please tomorrow morning. Lord Lansdowne expressed himself most kindly about you personally.

(Harewood MSS:)

\section{I77. Charles Arbuthnot to Robert Peel.}

Woodford, nr. Kettering. Ig April. Private-_... The lie now is that the Duke communicates with Lord Grey!! On my return to London I shall see Street who used to conduct the Courier, and I am sure we owe it to the Duke not to let him be so assailed by the Press without taking some counter measures. They are much puzzled how to get Protestant Cabinet Ministers. I hear they offered my place to Lowther as a bait. I dare say this was a scheme of Croker's, as it was known that Lowther had always a desire to succeed me if I went elsewhere. . . .

(Add. MS. 40340, ff. I5O-I.)

I78. Charles Arbuthnot to William Huskisson.

Woodford. I9 April._Private.-Although I had already mentioned to the Duke all that you said about him when I was last 


\section{I26 THE FORMATION OF CANNING'S MINISTRY}

with you at the Board of Trade, I thought it as well to send to him the letter which I received from you yesterday. I know it will gratify him to see how you feel in respect to him, and indeed will gratify him the more at a moment when from other quarters he is so slandered and calumniated. The Duke has always thought of you in a manner that would be gratifying to $\mathrm{y}^{\mathbf{r}}$ feelings ; and I am sure that he unites with me in lamenting that your course and ours $\operatorname{sh}^{d}$ now be so wide asunder. Had you been the person to controul, great part of the evil, if not the whole, might easily have been prevented. I scarcely know whether I ought to mention it, but I am certain that you cannot have read the infamous and scurrilous attacks upon the Duke, in papers guided by the Government, without suffering much of the disgust $w^{\text {ch }}$ I have experienced. Long ago I heard from a friend of ours, when we were all acting together, that Planta had talked of his success in gaining over the Times. The Duke treats the whole with contempt; but some, whom you and I equally admire, are indignant at what they read. I am aware that all hope of coming again together is vanished for ever. But is it wise, is it just, is it dignified, to allow such abuse of a man who, in the opinion of us all, saved the Empire? I find that one of the lies now spread is that the Duke communicates with Lord Grey! What will be said next? Had the Duke been treated with common courtesy he $\mathrm{w}^{\mathrm{d}}$ have been still at the head of the army, tho' he must have retired from the Cabinet. I appeal to you as one who respects and regards the Duke equally with myself, and I ask you whether common decency does not require that such a man as he $\operatorname{sh}^{d}$ not be hooted at with blackguard scurrility?

I shall return to London in a day or two to prepare for my departure from my present house. I suppose that my successor will immediately be appointed. And now, my dear Huskisson, let me once more assure you, as I can truly, that I grieve for the separation between you and me, and that unlikely as I fear we are ever to reunite in public life I shall never cease to feel for you a most sincere regard.

(Add. MS. $3^{8} 749$, ff. I98-9.)

\section{I79. Viscount Sidmouth to Lord Bexley.}

Early Court. Ig April. Private.-I consider your letter, which I receiv'd this morning, as an additional proof of your unvarying 


\section{THE FORMATION OF CANNING'S MINISTRY}

confidence and friendship. You are certainly placed in an unpleasant situation; but, I am confident, that you will have full credit for having acted from no consideration but that of public duty. It appears to me however that the grounds of complaint, on the part of Ministers, of the want of a timely and explicit communication of what was really intended, are far stronger than any which can be brought against any of them for precipitancy : and I am decidedly of opinion, that it was much better to decline forming an official connection, than to run the risk of its being speedily, and unpleasantly dissolved. I know nothing of the particulars of what has pass'd but from your letter. . . .

(Sidmouth MSS.)

\section{J. W. Croker to Viscount Lowther.}

I9 April. Confidential.-We hear that negociations are going on with the moderate Whigs such as Lords Carlisle and Lansdown, William Lamb and Calcraft; but I know nothing certain. I do not like this, if it could have been helped, but when 4I resignations come in at once, and that no Tories would consent to stay, what, I ask you in fairness, could $M^{r}$ Canning, what could the King do ? Were they to submit unconditionally to the whole party of Whigs with reform and Catholic question and all ? Those who object to reform and Catholic emancipation must surely approve of any step which tends to leave those questions in their present position. If you, even you individually, had staid, I think we should never have been driven to the Whigs. After all perhaps there will be no such alliance, but if not, how is the business of the country to be done: for I suppose those who have resigned cannot quite suddenly come back. Plunkett, they say, is not to go to Ireland, but to be M. of the Rolls here. If so, see what a pledge of sincerity that is, on $\mathrm{Mr}^{\mathrm{r}}$ Canning's part as to the Protestant question. On the whole I cannot see any reason why you should be in oppositionit is discordant to your nature and your principles to be so. I think Beckett's resignation might be superseded by royal command, and if you did not wish to appear so soon in the Woods \& Forests you might remain out for a season, but not in opposition. This is what I most anxiously hope for. . . .

(Croker MSS.) 


\section{I28 THE FORMATION OF CANNING'S MINISTRY}

\section{8r. Lord Howard de Walden to Sir Charles Bagot.}

F.O. I9 April, 6 p.m. Most confidential.-We go on, mais à pas. Copley has behaved like a man \& proved himself one for troubled times. He took his line decidedly at once without the slightest hesitation, \& embarked with $\mathrm{M}^{\mathrm{r}} \mathrm{C}$ [anning] before he knew $M^{r}$ C.'s strength $-\&$ indeed at a moment when some of our friends began not only to be alarmed but also to show symptoms of despondency. $L^{\mathrm{d}}$ Anglesea has taken the Ordnance, without Cabinet, which was offered at the same time. Is not this a signal piece of good fortune? Conceive Kill'em in Cabinet!. We shall I fear have a hard tussle in the $\mathrm{H}$. of $\mathrm{L}^{\mathrm{ds}}$ - there is our difficulty at present. The $\mathrm{K}$. makes a point of having a Protestant Home Secty, but there is no such creature to be found-not only not fit, but not even one who would not be generally discreditable to Govt. Under these circumstances $\mathrm{H}$. My must give way-\& then I think we shall do.

You will perhaps hear of the letters $\mathrm{w}^{\mathrm{ch}} \mathrm{Mr}^{\mathrm{r}} \mathrm{C}$. sent to the $\mathrm{D}$. of W. characterised as impertinent, insolent, \&c. I can only assure you that there is not the slightest grounds [sic] for such reports\& moreover that the D. of W.'s last letter certainly showed no indication of his having taken them in that sense, \& if the tone of them had influenced his decision, he is a man who could have resented the insult and who $w^{d}$ not have stated other grounds for his retirement. He does however conclude by saying that giving Mr C. credit for the best intentions-that he thinks that the principles of $L^{d}$ L[iverpool]'s Govt cannot be maintained, that the Gov ${ }^{t}$ will not have the confidence of the country, that he thinks he shall ultimately be obliged to retire from the Gov ${ }^{t}$. With those feelings $\&$ as his retirement would at no time be attended with less inconvenience than at the present moment, he must beg $\mathrm{H}$. My to excuse him, \&c. Well! the Duke not only goes out himself but insists upon all his friends going out too-Gosh ${ }^{1}$ \& all!! - gets up a cry against Mr C.-sends his A.D.C.'s to the Clubs, \&c., to talk loudly $\&$ complain \& does everything in his power to force every Protestant out. This is not enough. $L^{d}$ Melville, poor weak man, is goose enough to consult him-\& gets such a decided answer from him that he too must needs go out. I know not who advised Van-damn

1 Arbuthnot. 
to return-we can do no more than ring the changes on the above 2 syllables - a little hypocritical evangelical sneaking fox. ${ }^{1} \mathrm{He}$ may however bring with him those sinners the S[ain]ts. . . .

(Bagot MSS.)

I82. Henry Hobhouse to Viscount Sidmouth.

Whitehall. I9 April,-Private. . . . This office ${ }^{2}$ has been hawked about to every Protestant-Lord Farnboro'-the Speaker-Wallace -accompanied with an offer of a peerage to each of the two latter. But nobody bites. I fancy it now stands with Lord Lansdowne, and that he has sent to ask $L^{d s}$ Spencer and Fitzw ${ }^{m}$ leave to take it without bringing the bulk of his party with him. Whether the King will consider $\mathrm{L}^{\mathrm{d}} \mathrm{L} \longrightarrow$ a good Protestant, I do not know ! The same difficulty exists as to the Vice Royalty of Ireland, which is said now to stand with the Duke of Rutland. But the fact is, that nothing is certain, but that nothing is settled. Your letter to $\mathrm{L}^{\mathrm{d}}$ Huntly will not reach him in time to counteract that which is said to have been despatched to him from Downing Street. ${ }^{3}$ But I believe there is little occasion for a counteracting influence in that quarter. ...

(Sidmouth MSS.)

183. Lady Harriet Leveson-Gower to Charles Arbuthnot.

Richmond. Thursday [I9 April].-I cannot express how very kindly I take it in your having taken the trouble to write me the long letter I have just received . . . I wish $\mathrm{L}^{\mathrm{d}}$ Francis was at home to read the letter. He has been much annoyed by hearing from different quarters that " he was violent against the Duke $\&$ abused him for his conduct." He is therefore gone to town today, hoping to see the Bathursts \& to clear himself of any such an imputation [sic]. It is peculiarly disagreeable to him to have it supposed that he sh $^{d}$ speak disparagingly of the Duke ; but without a competent knowledge of all the circumstances \& with the impression which may have been conveyed by what has transpired publicly, was it wrong to say " he feared the Duke acted hastily in throwing up the command of the army," \& that was all he ever did say. I

1 Vansittart, Lord Bexley.

2 The Home Office.

${ }^{3}$ Hobhouse wrote to Sidmouth on the 2Ist: "I believe an offer of the Irish Government has been made to Lord Huntly." (Ibid.) 


\section{I30 THE FORMATION OF CANNING'S MINISTRY}

earnestly hope that office will not be offered or accepted until he has read your letter. It is essential that what he does should be done with his eyes open. . . . I have come to one conclusion, that viewing Mr C.'s conduct in the light he did, he, the $\mathrm{D}$., was quite right to resign. I am delighted also at what you tell me of his distaste to being himself the Prime Minister, as the other side all said "Oh he resigned because he did not chuse anyone sh $^{d}$ be Prime Minister but himself." The conditions on which Mr C. has come in are indeed astonishing.

I really do not know whether after reading this letter $F$. will take office or not. $\mathrm{He}$ is annoyed altogether about the view his friends on your side of the question have of his taking such a step. At the same time his politics as long as he has been in the House have inclined to Canning's, \& in the event of an ultra entirely Protestant Government having been formed he must have been in opposition. He would certainly like [to] be employed for all sorts of reasons with which you are acquainted, but the bare idea of being hand \& glove with people as long as they are in power, \& leaving them as soon [as] they are out, is galling. I can hardly think any such imputation can be cast upon him considering the line he has always taken. Will you give me a candid opinion upon the subject? I will not expect it if it $\operatorname{sh}^{d}$ be disagreeable to you. ...

(Arbuthnot MSS.)

\section{Emily, Lady Londonderry to Lord Londonderry.}

North Cray. [c. I9 April.]-Canning has bamboozled the King, bought Lady C[onyngham] and the Doctor. ${ }^{1}$ Your part of the interview was excellent, his, though, mostly false. It is however true that the Duke of Wellington did assist in persuading him to employ C[anning]. I return your paper. I will certainly say nothing of the contents, but there is one part of it I wish generally known, which is that with respect to the Catholics, as one of Canning's tricks was to cause it to be given out by his toads that your brother's support of them was hollow, and that in fact he had given them up to oblige his Majesty. I send you the two letters, will endeavour to get the letters to George the Third, and his answer, which if I recollect right are of the very greatest impor-

1 Sir William Knighton. 


\section{THE FORMATION OF CANNING'S MINISTRY I3I}

tance upon this present occasion. I believe nobody saw the letters but Edward Cooke and myself. I only fear that in his rage for destroying papers they may have perished. I only owe the letters I now send you to having snatched them from the fire.

(Londonderry MSS.)

\section{James Abercromby to the Earl of Carlisle.}

[c. I9 April.]-I have talked with $L^{\mathrm{d}}$ Lansdowne \& I have fairly told him that $I$ think he owes it to Canning \& to himself to receive the proposition with a desire to remove rather than to raise difficulties. $\mathrm{He}$ assures me that he has a perfectly cordial feeling towards Canning. Great pains have apparently been taken to impress him with distrust. I only wish to have the proposal cordially received \& fairly considered. If in the end they differ it can't be helped. Ld Grey has declared entirely off on the ground of Copley's appointment \& I hear his relations have been taking that ground at Brooks's. Lansdowne says that Brougham was with him this morning \& all his language was that of the most perfect reason $\&$ fairness. God grant that he may continue in that state. Denison told me today that the Whigs had had a great deal to do with placing Canning in his present condition. If these hints are dropped on the eve of a friendly communication what will it be if they break off in ill humour. I am really very unhappy about the whole thing, \& I fervently pray for a good result, altho' my hopes are abated.

(Castle Howard MSS.)

\section{I86. Viscount Granville to the Earl of Carlisle.}

Friday morning, 20 April.-Will not Canning have a right to think himself unfairly dealt by, when he receives the communication of which Abercromby told us the substance last night-the condition insisted upon seems to be at variance with the tenour of those letters of Brougham \& Lansdowne, which were spontaneously communicated to him three weeks ago-in those letters an intimation was conveyed, that they would be contented with a Gov't of which he, Canning, should be the real leader, leaving the Catholick question, as it were in abeyance, but making such progress, as it must inevitably make, when the current of influence \& patronage was not directed as for years past it had been, in a 


\section{I32 THE FORMATION OF CANNING'S MINISTRY}

course to counteract it - encouraged by the sentiments contained in these letters Canning did not hesitate to kiss the King's hand, as his Prime Minister-he knew the apprehensions felt by the King upon the Catholick claims, \& though he would not bind himself by any pledge whatever, he thought that consideration for these feelings were due to the King [sic], that it was in fact politick to have a regard for them, $\&$ that he had the sanction of $L^{d}$ Lansdowne $\&$ Brougham for so doing-now the dictation implied in the condition to which I have referred seems to be repugnant to the feeling with which Canning had determined to act towards his Majestybut supposing even the case (which I know to be impossible) of Canning pressing it upon the King, $\&$ the King in consequence of being so pressed to comply with it, in my conscience I believe that you would do a lasting mischief to the cause of the Catholicks. You would scare a multitude of sober minded people, who might shortly be brought to concur with you, \& you would raise a NoPopery ferment in England, which wd adjourn for ages the peaceable settlement of this question. The effect on Ireland also would be bad-an exulting triumph on one side, \& a feeling of exasperation $\&$ despair on the other. As to the lead of the H. of Lords, although I am far from contesting abstractedly Lord Lansdowne's superior pretensions, I think he ought to have prevented its being insisted upon. I really believe that if Canning had not learnt from you that there was a disposition to allow it to be given to Robinson, he would, having pledged himself to Robinson, have abandoned the hope of any junction being carried into effect. I could not help giving vent to my feelings-it was with feelings of deep regret on every account that I heard last night what Abercromby communicated to us.

[PS.] Upon further conversation with Abercromby last night I found him disposed to suggest to Ld Lansdowne an alteration in the mode, if not in the substance of the drawing up the condition respecting the Irish Govt-and which I believe he will send this morning.

(Castle Howard MSS.)

\section{J. W. Croker to George Canning.}

Admiralty. 20 April.-Have you a certainty (and if so, when and whence acquired) that Peel would have resigned, if he had been beaten on the Catholic question? If you obtain any further 
THE FORMATION OF CANNING'S MINISTRY I33 information as to the propriety of complying with the Duke of R[utland]'s wishes, you will tell Stapleton to let me know.

(Harewood MSS.)

\section{I88. A. G. Stapleton to J. W. Croker.}

F.O. 20 April. Confidential.- $\mathrm{M}^{\mathrm{r}} \mathrm{C}[\mathrm{anning}]$ has a certainty from Peel himself. $\mathrm{M}^{\mathrm{r}} \mathrm{C}$. has no positive information respecting the $\mathbf{D}$. of R[utland]'s intentions-but what he has is more favourable than before.

(Croker MSS.)

\section{I89. J. W. Croker to A. G. Stapleton.}

Admiralty. 20 April.-I have heard this moment that the Duke of Rutland talks constitutional language; that he does not question the right of the Crown to choose its Minister; and that he has no objection to $M^{r}$ Canning personally. This $I$ have heard out of the streets. I have just had your note which confirms it to a certain extent.

(Harewood MSS.)

\section{I90. John Calcraft to George Canning.}

Hanover Square. 20 April.-I fear the negotiation with Lord Lansdowne is at an end, and having always told my friends that if it went off, I should, notwithstanding, adhere to your 'Government, I now tender my services on the footing I mentioned when I had the honour of seeing you yesterday morning, if you think they can be at all useful in completing your arrangements for filling up the Administration.

[Canning replied briefly: "I do understand you, and am very happy so to understand you." (Ibid.)]

(Harewood MSS.)

\section{Viscount Dudley and Ward to George Canning.}

Park Lane. Friday night [20 April].-I have a communication to make to you from the Whigs. Though I am not very sanguine about it, yet I think it may by possibility lead to some good. Tell me, if you please, whether you will receive it tomorrow morning, 


\section{I34 THE FORMATION OF CANNING'S MINISTRY}

and at about what hour. ... Perhaps you have already made arrangements that render a junction impossible-and in that case I need not trouble you at all upon the subject.

Ibid., Roehampton, 9 p.m.- I found your note on my return. Just before I left town I wrote one to you which by this time you must have received. I will take my chance for finding you about the middle of the day tomorrow. If you are engaged I can wait, or call again. A very large part of [the] Whigs is I know very anxious that Lansdowne should not stand out as to the Lord Lieutenancy. If you have not already engaged yourself on another side, I really hope that some arrangement might still be made with him. Brougham most anxious, and without any stipulation for himself, and I believe he has with him most of the Whigs in the House of Commons.

(Harewood MSS.)

\section{Charles Arbuthnot to Robert Peel.}

Woodford. 2o April.- : . . I am sure our line is to be temperate, but it is absolutely necessary when $\mathrm{P}^{t}$ reassembles that the truth $\mathrm{sh}^{d}$ be known. The endeavour is to run down and vilify the Duke. Canning now owns that he wrote his second letter in ill temper to the Duke, and he regrets it. Indeed, Huskisson had said to me that Canning had been out of temper by the Duke's first letter. Lord Hertford's conduct is what I expected, but good character alone can give them real support. [See No. I6o.]

I hear that four anti-Catholics have refused the Home Department. The Speaker would have taken [it] if he $\mathrm{c}^{d}$ have ventured to risk the pension to be granted when his services in the Chair are over. I thought by his manner when he spoke to me that his inclinations were that way. But it is idle to send you news from the country. ...

[PS.] I am rejoiced that the command of the army is not given away, and that Sir Herbert Taylor will be about the King.

(Add. MS. 4034\%, ff. 152-3.)

\section{The Marquess of Londonderry to the Duke of Wellington.}

20 April. Private. - You may depend upon it your injunctions ${ }^{1}$ in your letter of this morning shall be strictly adhered to. I have

1 Earnestly recommending moderation and temper. (W.N.D., iii. 654.) 


\section{THE FORMATION OF CANNING'S MINISTRY I35}

seen the $D$. of $N$ [ewcastle] since, and although I could not pacify his bitter feelings, I am sure he will be tranquil until the crisis developes itself further. Above all, the person of Majesty shall ever be treated with the utmost veneration and caution. However, my $\mathrm{d}^{\mathbf{r}}$ Duke, it is most difficult when one's whole soul is rous'd to indignation, to be calm, and remain with your hands before you, however inefficient one may be. For my own part my whole nature is rous'd to desperation at injuries done to those I love and admire, and am bound to by every tie of gratitude and devotion, when in my own person I could easily forgive and pass over what I despise. Ellenb[orou]gh has just left me. He tells me, altho the negotiation was broken off with Lansdown it is renewed, and $\mathrm{L}$ [ansdow]n[e] has been offered every thing brilliant, handsome, and considerate-the Home Department, management of Ireland, \&c. \&c., and large patronage for his friends. The underlings all want him to close. They are so rapacious. But Grey, Lauderdale, Rosslyn and himself will come in on no terms. But I think the leaning of Ellenborough's mind probably from the best source is that $L[a n s d o w] n[e]$ will make some Convention. In the meantime, the first nominations, and then being forced to the Whigs, shews the baseness of the whole transaction, and if even C[annin]g gains Lansdown without his compeers in the $\mathrm{H}$. of Lords, the defection of the Tories who have taken on, I conclude must follow Lansdowne's apptmt. Brougham is furious at Plunkett's nomination. He has Lord Darlington to manage for as B. likes [sic].

(Wellington MSS.)

\section{Viscount Strangford to the Duke of Wellington.}

Harley Street. 20 April. Confidential.-When I had the honor of writing to your Grace yesterday, I was not aware that you had left town. I wished to have had an opportunity of asking your sanction of a step to which I am strongly impelled by my duty to my five children. Under your Grace's most kind and friendly opinion, I have hitherto refrained from pressing a second application to $\mathrm{M}^{\mathrm{r}}$ Canning. ${ }^{\mathrm{l}}$ When I first spoke to him, after my return from Russia, he said that though he could do nothing for me, as Foreign Secretary, he thought that my situation gave me a claim on the Government at large. $\mathrm{He}$ is now in a position to prove

${ }^{1}$ For a pension. He had been Ambassador at Petersburg, 1825-6. 


\section{I36 THE FORMATION OF CANNING'S MINISTRY}

whether he was sincere or not in making that admission. I must not suffer my family to remain in its present condition, without hazarding an attempt (a fruitless one, I dare say) to amend it. But, without your permission, or at least, without the knowledge that such a measure would not be displeasing to you, I feel too strongly bound by every sentiment of respect and devotion towards your Grace, to venture upon it. My plan would be to go to $\mathrm{M}^{\mathbf{r}}$ Canning, and fairly state to him my just claim-not upon the ground of prospective parliamentary support-but on that of five and twenty years of uninterrupted public service-on that of the destitute condition of my children, the heirs to a British peerageand on his own assurance that my situation was one well entitled to the consideration of the Government. Whatever your Grace's opinion of this step may be, I do entreat you to pardon the frankness with which I have ventured to submit it to you. ${ }^{1}$

(Wellington MSS.)

\section{I95. The Duke of Rutland to Mrs. Arbuthnot.}

Belvoir Castle. 20 April.-I take an excessive interest in all your letters. This would be the case if they had not such a momentous subject on which to treat as that with which they are now filled, and you may therefore guess how anxiously they interest me at this moment. Every day seems to increase the importance of the present crisis. In the present state of things no man can tell what will be the issue of them. Of course much exaggeration prevails while the public mind is so highly excited, $\&$ it is difficult to ascertain how much is really true. I observe you had heard that Sir Henry Halford was thought too dangerous a persion for the King to converse with, whereas I have a letter from Sir Henry himself in which he says that he had been with his Majesty every alternate day since his arrival in London. It seems to me that $\mathrm{Mr}$ Canning will himself be forced either to change opinions which he has held, \& upheld during the material part of his political life, or abandon all hope of fixing himself firmly in his saddle. The King seems to be daily more \& more eager on the Catholick question, and I imagine he gives his Premier a full dose

1 He wrote again, next day : " . . : . If I do not hear anything to the contrary from you, I shall consider your silence as giving me permission to proceed in my plan-a hopeless one I doubt not-but still, one which in justice to my family, I think I ought to try." (Ibid.) 


\section{THE FORMATION OF CANNING'S MINISTRY I37}

of it every time he sees him. . . . It is evident that the Administration now forming must be essentially Protestant, more so perhaps. as to numbers than that which is recently dissolved. The question which I shall have to determine will be whether a Ministry of which the Premier is a pledged advocate of the Catholick claims, can be to the letter, founded on the principles of $L^{d}$ Liverpool's. Government. The Treasury we all know possesses patronage to an enormous extent, and I question whether the First Lord being favourably disposed to the Catholicks, may not do more mischief in the land, even if all his troops were Protestant, than if the reverse of this supposition were the case, and the Premier alone should be Protestant. We all know that the First Lord of the Treasury has in fact the appointment to all the dignities of the Church, and if he should be an advocate of Catholicism he may gradually make a most material alteration in our Church system, and we must arm the King, \& expect him to exercise a veto in the appointment of our Bishops. It is not possible for me to write as you suggest to Lord Manners, because I yesterday received a letter from his brother the Archbishop, informing me that at the King's express desire he had written to him to press him to remain in his high office in Ireland, at least till a proper Protestant successor to him can be found. It would therefore be an unauthorized act on my part if I were to endeavour to counteract the communication thus made from the Archbishop to his brother. My course is very straightforward. Things are at this moment in so unsettled a state that it would be the height of indelicacy for any one to sing out, either one way or the other until it is seen comment les affaires politiques s'arrangent. You are aware that if I am satisfied as to the principles \& efficiency of an Administration, my attachment is to the Crown rather than to any set of men. I shewed this to be the impulse of my conduct when $\mathrm{M}^{\mathrm{r}}$ Pitt, of whom I had an admiration ten times exceeding in degree that which I entertained for any other person in the land, gave up the reins of government to Lord Sidmouth. I make no scruple in owning to you that the man whom of all others I had now rather see at the head of the Government, is the Duke of Wellington. I have not told him so as yet, because I do not know whether such a declaration would not under existing circumstances rather annoy than please him, but I am as little likely to alter in my opinion on the subject, as he is to swerve from his principles. But I am confident if I asked his advice, he would give it to me, to wait patiently until 


\section{I38 THE FORMATION OF CANNING'S MINISTRY}

matters resolve themselves into some tangible form \& nature, and then to act accordingly-and I am sure this is the true line. I am quite convinced that the Duke has had motives for his conduct, equally noble, disinterested and undeniable--he who runs can read (or he must be a ninny if he cannot) that no man, setting aside all feelings of honor \& nobleness of mind, would be so dead to self interest, as to abandon a position of all others equal to his highest ambition \& wishes, \& which promised him glory \& happiness for the remainder of his life, without a cause that cannot be questioned. What that cause has really been, I of course cannot precisely know : but the time will probably come, and at no distance, when the transactions of the last month will be shewn in their proper colours. My intelligence from London yesterday stated that Protestantism was all the cry, and that Canning's people were seeking in all directions for firm Protestants to fill the various offices. . . . It is singular that in ten days only 3 or 4 offices should have been filled up. It shews the difficulties under which the King's firmness and decision on the Catholick subject has placed Mr Canning. I consider the latter as going about with a Protestant tin kettle tied to his tail, and a galling appendage it must be to him, if he has consistency or honor in his nature. . . .

(Arbuthnot MSS.)

\section{I96. Lady Georgiana Louisa Bathurst to Mrs. Arbuthnot.}

Friday, [20 April]. -We are waiting open mouthed to hear the final decision of the Whigs. We think they must have sent into the country for advice for the answer was delayed $\mathrm{fr}$. yesterday till today, when $\mathrm{W}^{\mathrm{m}}$ Ponsonby is to let us know whether $\mathrm{L}^{\mathrm{d}}$ Lansdowne has consented or not. This is the $2^{\mathrm{d}}$ negociation. I can hardly think he will be allowed to accept when it is known under what conditions he undertook from the King the formation of the Govt. Have you heard that they have sent off to Ld Huntly to offer him the Lord Lieuty of Ireland-not very likely I think that he will accept-he hates $C[$ annin]g \& has the greatest admiration for Mr Peel. When you come to town you will be quite satisfied with $L^{d}$ Anglesea when you hear his conversation with Sir Henry Hardinge \& his letter to $L^{d}$ Londonderry-which $L^{d} L$. repeated to papa. I am a little afraid $L^{d} \mathbf{L}$. has been too violent. I understand the $\mathrm{K}$. is angry with him. ... $\mathrm{L}^{\mathrm{d}}$ Dudley is at Brighton $\&$ denies having had anything offered to him or knowing anything 


\section{THE FORMATION OF CANNING'S MINISTRY 139}

at all about the Administration. I should rather suspect that $\mathrm{L}^{\mathrm{d}}$ D. may perhaps think his dear friend C[annin]g has not done wisely in offending \& separating fr. the aristocracy. $L^{d} D$. is a great aristocrat.

The other day at the great dinner $C[$ annin]g gave to the $\mathrm{D}$. of C[larence] \& the new members, Ld Palmerston was unwell \& left the room. This brought $L^{d}$ Bexley \& Sir John Copley next to each other \& the latter addressing himself to $L^{d} B$., to the infinite amusement of all the table, said, "I wonder whether he will come back again."

If you hear that $\mathrm{L}^{\mathrm{d}}$ Francis Levison has abused the Duke, dont believe it. They are at Richmond \& he came here yesterday mors quite unhappy at such a report \& begged we w ${ }^{d}$ not let the Duke for a moment believe it. He has certainly (as I am sorry to say all the young men have) a profound admiration for the gentleman, as $\mathrm{L}^{\mathrm{d}}$ Anglesea calls him, but I am sure he w $^{\text {ld }}$ not abuse the dear Duke. $L^{d}$ Ashley is gone to Leamington \& he admires Canning's talents more than I quite like-but he is up to him. $\mathrm{I}$ had $\mathrm{g}^{\mathrm{t}}$ pleasure in telling $\mathrm{L}^{\mathrm{d}}$ Francis of their having sent off to $\mathrm{L}^{\mathbf{d}}$ Huntly to propose his being $\mathrm{L}^{\mathbf{d}} \mathrm{L}^{\mathrm{t}}$ of Ireland. He asked what his talents were. I said he was a very good humoured merry person \& a most vehement anti-Catholic. He looked rather discomposed I thought. It is very painful to me for (like you) I am bursting with indignation agst $\mathrm{C}$ [annin]g, but with the young men $\mathrm{I}$ find that if one flys out too much they will not listen, one \& only set me down as too prejudiced to be attended to.

Since writing this we have heard that the Whig answer can't come till this ev $^{\mathbf{g}}$. $L^{\mathbf{d}}$ Fitzwilliam \& $\mathbf{L}^{\mathbf{d}}$ Spencer are they say the two people to whom they have sent. $L^{d}$ Manners will not remain I believe but the $\mathbf{K}$. will not hear of Plunkett so $\mathrm{C}[\mathrm{annin}] \mathrm{g}$ has given him such a sop. He is to be Master of the Rolls. What luck for him! There he is landed for life. It will create $\mathrm{g}^{\mathrm{t}}$ dissatisfaction in the English Courts of Law. We hear that the Prime Minister is in roaring spirits-not exactly flushed with success I shd think, but all his dear friends I suppose tell him that he will triumph over all difficulties. The $\mathrm{D}^{\mathrm{ss}}$ of Gloster has seen our gracious, but she can say nothing for he talks all himself $\&$ tells her a most pitiful story, but has not been violent against any of us. It is then very difficult to say, "But all H.M. tells your R.H. is not true "-so it ends in her crying about it all, poor thing, and one can say but little. As for $L^{d}$ Lauderdale I suppose H.M. would 


\section{I4O THE FORMATION OF CANNING'S MINISTRY}

as soon see old Nick. In the summer $\mathrm{L}^{d} \mathrm{~L}$. told me he saw what favours C[annin]g was gaining over him, for that formerly he used to tell him all his grievances, but that then he had found he $w^{1 d}$ not enter at all into public affairs with him.

I send you the Leeds Intelligencer for you to read in the carriageit is very refreshing after the nonsense the other newspapers write... .

[PS.] $\mathbf{M}^{\mathbf{r}}$ Rogers has just been here. Holland $\mathrm{H}$ [ouse] intend supporting the new Govt. $W^{m}$ Ponsonby has also been here-he says they know nothing but is inclined to think $\mathrm{L}^{\mathrm{d}}$ Lansdowne will join. It $\mathrm{w}^{\mathrm{ld}}$ be a $\mathrm{g}^{\mathrm{t}}$ thing for them. What will become then of Copley I wonder \& how soon they will kick out poor Van.

(Arbuthnot MSS.)

\section{Lord Ashley to Mrs. Arbuthnot.}

Leamington. 20 April.-Women are very discreet or very indiscreet, they have no moderation. That is a general rule. Now, my dear Mrs Arbuthnot, you are a marvellous person for prudence nine cases out of ten. Upon my word I trust greatly to your statesmanlike qualities, but the exception proves the rule, and in a late instance you have proved it indisputably. It is mentioned in London that your language about our gracious [Sovereign] has been most loud and most angry. Is not that a little ill-judged? A few words carried to his ears might inflame them so dreadfully as to render all good humour for ever impossible. All people believe that you are speaking the Duke's sentiments; well and good, but however just they may be, I had rather see his Grace Commander in Chief, than foaming about in acknowledged undeservedness of his ill-treatment, when all might have been made up consistently with feeling \& dignity. Now you will not be offended at this remonstrance, because you know that I have a real kindness towards you. I cannot show it better than in doing that which I know to be serviceable. You will therefore put the affront in your pocket, if you wear pockets. . . Poor Francis Levison is quite in sorrow on the Duke's account - now pray be cautious and sweet-tempered also.

(Arbuthnot MSS.)

\section{Henry Brougham to Viscount Althorp.}

Friday $[20$ April]. - . . . Canning has been doing sad things I fear-and trying to find questions which may unite us with Eldon. 


\section{THE FORMATION OF CANNING'S MINISTRY I4I}

Copley's appointment was bad-Plunket is Master of the Rolls and a peer-two men utterly incapable of doing the business of day. This is worse for Chancery suitors a hundred times than Eldon himself. ${ }^{1}$

(Althorp MSS.)

\section{James Scarlett to George Canning.}

2I April.-I am not sure that Lord Lansdowne would not renew if he was made to understand that the proposition might still be modified; my reasons for thinking so are the strong and general feeling that exists amongst his friends against $i t$, and an observation made by him to me last night that he concluded that he could not revive the negotiation. He seemed to think that if he and those he had consulted were disposed to relax, the door was not at present open to any further communication.

If you think or wish that anything further can be done, it appears to me that you have only to let me know that his condition cannot be received and that you would be glad if he could upon consideration withdraw it. I am sure that he will consider this as calling upon him to make some other proposal if possible, and the urgency of his friends may then act upon him. He was very strenuous in advising me to accept your offer. I have written to Lord Fitzwilliam $^{2}$ and must depend on his answer-at least, so I think at present.

(Harewood MSS.)

\section{George Canning to James Scarlett.}

F.O. 2I April.-I saw Mr Tindal last night and he most handsomely consents to accept you for his chief.

I do not answer the other part of your note, because I am already in communication with a person ${ }^{3}$ who has been sent to me. (Harewood MSS.)

1 Parts of this letter are quoted in my Brougham and the Whig Party, p. I5I ; and in E.H.R., April 1927, p. 208.

2 Who provided him with a seat in Parliament.

3 The Duke of Devonshire. 


\section{I42 THE 'FORMATION OF CANNING'S MINISTRY}

\section{George Canning to Viscount Dudley and Ward.}

F.O. 2I April, 9 a.m.-I have certainly impaired my present means in a small degree-in plain terms I have made an offer ${ }^{1}$ of one of the Cabinet places in the House of Lords (not the principal one) since I received the answer through Carlisle which he as well as I considered as decisive. But I held my hand, on hearing from you, and I am by no means sure that my offer will be accepted. If it be so, it will be by a person nearly eiusdem generis. I shall not know his name till Monday. ...

Ibid., F.O., 2I April.-The Duke of Devonshire has been here, and is gone down to Lord Lansdowne. ${ }^{2}$ I have engaged to wait till Monday morning. Should I not do wrong to enter into any cross communication while this mediating mission is pending ?

(Harewood MSS.)

\section{William Lamb to George Canning.}

Whitehall. 2I April.-I saw Lord Lansdowne yesterday evening, and he confirmed to me in every particular the statement which you had made. He said that he considered the negotiation as entirely concluded, that the constituting the Irish Government in the manner which he proposed, was a point from which he could not depart ; but that he should not be unwilling to admit a principle of commutation, that is, that he should not object to having the Government here formed in a greater proportion of anti-Catholics, provided he could have the Irish Government, by which he means the Lord Lieutenant and the Secretary favourable to the claims of the Roman Catholics. This is the sum of what he said. When I left him I went to Brooks's, where I found that amongst the persons present, about thirty or perhaps forty, including Brougham, Burdett, Calcraft, \&c. \&c. there prevailed a strong and almost general feeling of disapprobation of the decision to which Lansdowne had come. Some of them went to remonstrate with him, and I do not know whether some general representation upon the subject was not drawn up and sent to him. These steps, I am afraid, can hardly be expected to induce him to reconsider his determination, although I think it might have been different, if he had taken a little more pains beforehand to ascertain the opinions of more of those with whom he was acting. This

1 To the Duke of Portland.

${ }^{2}$ Who had returned to Bowood after the breakdown of the negotiations. 


\section{THE FORMATION OF CANNING'S MINISTRY I43}

crotchet about the Irish Government is felt by almost everybody to be just such another obstacle as the Whigs have always contrived to raise up against their own entrance into power. I thought it right just to tell you what had passed between me and Lord Lansdowne.

(Harewood MSS.)

\section{J. W. Croker to George Canning.}

2I April.-May I come over or if not now, at what hour? I have seen Lord L[owther], and have had a satisfactory conversation with him.

(Harewood MSS.)

\section{George Canning to Sir William Knighton.}

F.O. 2I April.-I will wait upon his Majesty about four o'clock. I have seen the Duke of Devonshire this morning, and have given him till Monday for his decision. I send you three Whig letters. Tindal, with admirable good humour and good taste, agrees to serve under Scarlett. I have also seen Lord Dudley. More of that bye and bye. I have not seen Croker because we cannot use both strings of our bow at once.

(Harewood MSS.)

\section{Viscount Dudley and Ward to George Canning.}

Brooks's. [2I April], 2.30.-There seems to have all along existed some misunderstanding as to a very important point. If so, it must be quite fatal. The Whigs conceive that the Secretary was to be Catholic, and that they had only to struggle for a Catholic Lieutenant. From our conversation this morning I am pretty sure I collected that the whole Government of Ireland being Protestant, is a sine qua non from which you will not, because you cannot, recede. Pray let me have a single word as soon as you conveniently can, to clear up this matter, which you see at once is of the greatest importance. I am utterly amazed that any misunderstanding should have existed upon such a point-but such is the fact. I shall come back to this place by and bye, so be so good as [to] direct your answer to me here.

(Harewood MSS.) 


\section{I44 THE FORMATION OF CANNING'S MINISTRY}

\section{Thomas Spring-Rice to the Marquess of Lansdowne.}

2I April.- . . . It has been intimated to me that it would be agreeable if I should accept office under the new Government. My answer was, first a declaration that independent of any such question, it had been and was my wish and intention upon the principles laid down to vote with the Government zealously and anxiously. That with regard to the proposition itself, it was one which I could not under any circumstances entertain whilst there was the prospect of really forming the Government through your co-operation. And that even if that prospect was closed, I should feel extreme difficulty indeed in considering any question affirmatively on which you had put your negative. Still, that I would consent that the matter should be left open for communication when the time came. To you, my dear Lord, I repeat all this, not exaggerating the difficulty and pain I should feel, even notwithstanding your communication to me in taking the suggested step. Without that communication it would have been impossible to me. But I thought on every account without binding myself to any specific course it was expedient to answer as I did. I add nothing in respect to what has since passed as you will hear it from other quarters better than from me.

(Bowood MSS.)

\section{The Marquess of Lansdowne to Lord Holland.}

B. Sq $q^{e}$ Saturday morning [2I April].-I am obliged to leave town without seeing you, \& very early. You know there are reasons why I cannot defer it, but I shall consider it as an act of friendship in you if you will come into town today \& defend me after all that has passed, for after three days' vexation, on the point of starting, I am overwhelmed with letters reproaching me in friendly of course but strong terms, for making the difficulty I did about the I[rish] Govt, $\&$ this too from those who concurred in the minute- $\&$ from all the Irish (Newport for instance) who have for years been telling me that a divided Govt in Ireland is worse than a Tory Govt united.

I feel this most cruelly to be accused of abandoning Ireland when I am in fact struggling for it.

How can $I$ write \& retract ? Would it be wise, would it be safe for me to do so ? I will support Govt_-I will recommend those who think they can take office to do so-I will listen fairly to any fresh 


\section{THE FORMATION OF CANNING'S MINISTRY I45}

proposition that can be made--but I confess with an earnest wish to keep out - tho' everybody tells me it is no support if I do not take an office. At all events I rely on your kindness to vindicate me for simply acting on the resolution taken-which as I now see is to be represented as obstinacy, punctilio, \&c.

I shall not be sorry from what I have seen of the steadiness of opinion of friends, if I have another answer to give, to give it where I am alone \& can think with myself instead of talking with others.

(Holland House MSS.)

\section{Lord Holland to the Marquess of Lansdowne.}

Holland House. 2I April.-I will go to town and with all I see defend your stipulation. In truth George III conceded it in I806, why not George IV in I827? I think however the negotiation will be in spite of you, revived. On reflecting on your paper I must acknowledge that one fault occurred to me, for which we all are as much and more responsible than yourself-viz. it was I think proper and necessary that the principle by which an individual at his discretion was entitled to propose making concession to the Catholics a Cabinet question, should be laid before the King. But perhaps it would have been more prudent to have stickled for the other point with Canning only, that is, to have insisted with him on the Government of Ireland being uniformly Catholic, but not have insisted on the King's knowing that to be our condition, but to have satisfied ourselves with the fact if Canning had been willing or able to manage it. As to relaxing that condition hereafter I should think that the earnestness of your friends and the substitution of some equivalent might reasonably induce you to do so, provided there are no other signs of over compliance with the hostility of the Court to the question, and provided you and your friends are bonâ fide admitted to the full share of authority as well as mere place, to which your personal qualifications and your station in Parliament and the country clearly entitle you. I lay great stress on this latter clause, for I think you are too easy on such subjects. Without much pride, I trust, in my character, I would not submit to be led in the House of Lords by a person brought there to lead me, with whom I was personally unacquainted and who in station and consequence is certainly inferior, and I should think in fitness for the situation too, to my natural representative in that House and in the Government. Nor is this all. Canning seems to me, on the principle of being appointed 


\section{I46 THE FORMATION OF CANNING'S MINISTRY}

Minister himself, to think that all under him are mere individuals who hold of him and have no substantial weight, authority of their own. If you act and co-operate with him, it must be, if not of terms of perfect equality, at least as a substantive power which brings an accession of strength to him and to his Government in Parliament, in England and in Ireland, which he cannot otherwise commandand he must give you either a joint voice in all his own important patronage, or surrender a distinct and definite share thereof, for the purpose of enabling you to keep that power essential to your own character and importance and to the stability of the Government to which you belong, firmly together. It is you well know always inconvenient to break off upon one point, for the last feather which breaks one down may always be called in itself light. I should therefore say that you stickled for what was granted without its being asked for by George III, and what was thought essential by us all - but after all if you could contrive to answer the same purpose by any other concession on their part, I would listen to it.

[PS.] On the point of your precedence in the House of Lords I have reason to believe that Robinson, far from being easy or indifferent, stickled and insisted upon the lead, and that he is in the opinion of Canning and his friends rather an intractable personage. $\mathrm{He}$ is I suspect half inclined to resign, and is much courted by Londonderry's squad. As to our own friends they are in a mood to blame us outrageously if we do not join, but to consider us as abandoning both our principles and our friends if we do, without obtaining more than is in our reach for one and the other. . .

[PPS.] My prediction is true ; the thing I find from my visit at Devonshire House is renewed. All I can say is that the question of Irish Government though reasonable and important, is not the condition on which my support is offered, to which you are welcome if you compromise that matter at all to your satisfaction, and enter into office with the sort of power, patronage, and lead to which your station and the confidence reposed in you entitle you; but if not, not. Abercrombie puts this in his letter, or sends it. I had no notion till he told me of the unjustifiable step at Brooks's.

(Bowood MSS.)

\section{Sir Francis Burdett to the Marquess of Lansdowne.}

2I April.-I am told, and thereby much flattered, that you expressed yourself sorry that for want of knowing of it, I was not at 
the meeting last night at Lansdowne House, and that it would be agreeable to you to hear from me upon the subject then under consideration, viz. the negotiation broken off, not irrevocably I trust, with $\mathrm{M}^{\mathrm{r}}$ Canning, the terms of which, I understood generally to have been these : eight out of ten friends to Catholic emancipation in the Cabinet, and though a Protestant, not a violent Lord Lieutenant in Ireland, with a Secretary friendly to Catholic emancipation, and, although not named for it, no probability of any objection to your holding the Home Secretary's office, and therefore in fact having the control over the Government of Ireland. I must own if this is anything like the truth, I do deeply regret that a change of situation so advantageous in every point of view should be obstructed by what seems to me so trivial an objection as is, under such circumstances, the appointment of a moderate Protestant, Lord Lieutenant for Ireland. By such an arrangement everything seems to me, if not instantly gained, eventually secured . . . I cling to it [Canning's proposition] because it appears to me not only the most fortunate and unlooked-for event, but the only chance in our time of effecting any great practical good; for however much I may be attached to theoretic principles, no one is more alive than I am to the wisdom and necessity of seizing on every opportunity that presents itself for obtaining practical benefits. I cannot think it wise to reject a great deal that is most desirable, because all that is to be desired cannot be, and at once, obtained. . . . A greedy, bigoted, narrow-minded faction has like a nightmare oppressed the country ever since the commencement of the reign of George III to the present time, and so exhausted it, or possessed themselves of its strength, that it had lost the power, and almost the will, to shake it off. This their strength, however, probably produced their overthrow, for presuming too far, thinking they could not be got rid of, when no one else could, they unseated themselves, having done so, are we to endeavour to set them up again?...

(Bowood MSS.)

\section{2ro. Henry Hobhouse's Diary.}

Saturday, 2r April.-The first step wch Canning took was to make the Duke of Clarence Lord High Admiral. Of this his friends boasted as a coup de maître, inasmuch as it at once shut the door agt Ld Melville's return, and so punished him, and conciliated the Duke (who has lately expressed himself very contemptuously of Canning) 


\section{I48 THE FORMATION OF CANNING'S MINISTRY}

both as heir presumptive and as future Sovereign. The appointment is said to have been suggested by Croker, who has within these 3 months been told by H.R.H. that when he acquired the command of the navy Croker shod have nothing to do with it, and therefore had a deep interest in ingratiating himself with the Duke. H.R.H. hailed the choice, and evinced his gratitude to Croker by immediately appointing him his Secretary. The wisdom of the appointment, and its effect on the Duke and Croker, remain to be seen. It is not a light thing to place an almost irresponsible person at the head of a Dept with so immense an expenditure as the navy.

No successor has been found for the D. of Wellington as Commander in Chief, and the King has recurred to the notion, $w^{\text {ch }} \mathrm{L}^{\mathrm{d}}$ L[iver]pool counteracted 3 months ago, of commanding the army himself. He sent for Sir Herbert Taylor on Wednesday, and communicated to him the determination. He proposes to execute it by an Adjutant and a Quartermaster Gen ${ }^{1}$ and an officer in the nature of a Secretary, but with some new title, who is to be Sir H. T. As soon as Sir Herbert heard of the K.'s intention, he represented to $\mathrm{M}^{\mathrm{r}}$ Canning the difficulties wch occurred to him in putting thẻ command of the army on this footing. He was desired not to state the difficulties to the King, and accordingly appeared to acquiesce in H.M.'s commands. But both he and the other military men, to whom the intention is known, concur in thinking that the adoption of this scheme for 3 months would demolish the fabric $w^{\text {ch }}$ it has cost the D. of York 30 years to raise. And if by the appointment of the $D$. of Clarence the navy will be left with a head nearly free from responsibility, the army will by the new plan be under one wholly irresponsible at least as to the patronage. As to its expenditure there will certainly remain a control in the Secretary at War. But there will be such an interference with his office, that $L^{d}$ Palmerston has taken fright, and thinks it incumbent on him to remonstrate.

Sir John Copley, the late Atty Gen ${ }^{1}$, who upon $L^{d}$ Gifford's death last Septr took the Rolls, altho' he had never practised in a Court of Equity, has been appointed to the Great Seal, the King telling him that he made him his Protestant Chancellor. Such is the dearth of eminent lawyers, that there was scarcely any choice, and Copley in taking the Rolls clearly indicated his ambition to be Chancellor. The selection of his successor at the Rolls is a most extraordinary one, and can not fail to excite a strong sensation in the English Bar. Plunket the Irish Atty Gen $^{1}$ being objected to by the King for the 
Great Seal of Ireland, on acct of his advocating so strongly the claims of the Roman Catholics, it became necessary to dispose of him in some other manner. He is therefore to be Master of the English Rolls, and to be compensated for the inferior station by an English peerage. This elevation is to be rendered more palatable to the English bench by advancing to the same dignity the Chief Justice of the K.B. Thus there will be 4 new Peers, viz. Copley, $L^{d}$ Lyndhurst ; Robinson, the Chancellor of the Exchequer who is to succeed $L^{d}$ Bathurst at the Colonial Office; Abbott, Ch. J. to be $L^{d}$ Tenterden ; and Plunkett, to be $L^{d}$ Plunkett. The Marquis of Anglesey has accepted the Mastership of the Ordnance, and $L^{d}$ Granville the Foreign Office. These, with what have been before mentioned, are the only arrangements actually settled ; and of these none have been proceeded in, except that the Gazette has announced the D. of Clarence's appointment to be $L^{d}$ High Admiral, and that Robinson yesterday delivd up the Exch ${ }^{\mathrm{r}}$ Seal, $w^{\mathrm{ch}}$ the King entrusted to Canning, this being necessary before C.'s election, $w^{\text {ch }}$ took place on that day.

The grand difficulty has been to fill up the Home $\mathrm{Dep}^{t}$ in a manner consonant with Canning's promise to the King. [He offered it to $L^{d}$ Bathurst, who declined it.] ${ }^{1}$ It was successively offered to and refused by the Speaker, $L^{d}$ Farnboro', and $M^{r}$ Wallace. The first was the only one who hesitated in his refusal. He would probably have accepted it, if a pension could have been secured to his son as well as to himself, as will follow from his continuing in the Chair of the House of Commons. A peerage was offered both to him and to Wallace.

The King, in order to obviate the alarm $w^{\text {ch }}$ might be taken by the Protestants in consequence of the tenets of the new Ministers, sent for the $\mathrm{Ab}^{\mathbf{p}}$ of Canterbury and the $\mathrm{B}^{\mathbf{p}}$ of London, assured them of his firm determination to support the Established Church, asserted that he was and always had been as decided an enemy as his father to the Catholic claims, and had so declared to $\mathbf{M}^{\mathbf{r}}$ Fox in $\mathbf{I} 806$, and authorized them to communicate these sentiments to their brethren. The King has also given audiences on this subject to the Duke of Newcastle and the Marq. of Londonderry, to the former as a Peer, and to the latter on his resign ${ }^{\mathbf{g}}$ his $\mathrm{Ld}^{\mathbf{p}}$ of the Bedchamber. Of what passed at the former, little has transpired, and the correctness of what has been stated of it on the King's authority is impeached by the Duke, who however does not feel himself at liberty to disclose what

1 The portion enclosed in square brackets is a marginal addition. 


\section{I50 THE FORMATION OF CANNING'S MINISTRY}

actually passed. The Duke is too zealous an anti-Catholic to leave a doubt that he advised H.M. to form a Govt entirely of his own principles. $L^{d} \mathrm{~L}$. was exempted from all restraint on the head of secresy by the King himself, and makes no scruple of declaring that the King used most contemptuous language of Canning, complained that he had been forced on him in I822, and that he (the $K^{g}$ ) was illtreated by those who then so forced Canning now refusing to serve under him, but that he was determined to have an entire antiCatholic Govt in Ireland, and half anti-Catholics in the Cabinet, w ${ }^{\text {ch }}$ rule he wod observe so strictly, that whenever a vacancy is made by one of that party, he will supply it by a man of the same principles. How far these professions are consistent with the negotiation $w^{\text {ch }}$ has been carried on between Canning and the Whigs remains to be seen. $L^{d}$ Londonderry is himself friendly to the Catholic claims, as his brother was. His objection was therefore personal to Canning, and he has written a letter to Robinson, upbraiding him with a dereliction of principle, in having deserted the measures of the late

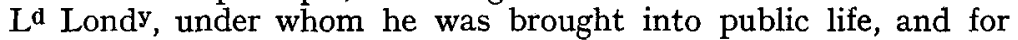
whom he professed in 1822 the most unbounded veneration, and addicted himself to Canning, by whom the late Lord L. was so illtreated.

(Hadspen House MSS.)

\section{Ir. Viscount Sidmouth to Viscount Exmouth.}

Early Court. 2I April. Private.-You have been often in my thoughts within the last ten or twelve days, but I have not written, as $\mathrm{I}$ am not fond of dealing in lamentations. In my own mind however there has not been a stronger feeling than that of indignation at the attempts in which almost every newspaper is engaged, to vilify and calumniate persons whose principles, fidelity, zeal and fortitude have been long proved, and never found wanting, and to whose services the country has incurred the debt of eternal gratitude. Their characters and the whole course of their public lives, ought to crush all the imputations against them of having failed in duty to the King. Surely they acted more becomingly towards his Majesty, and more honourably towards $M^{\mathbf{r}}$ Canning, by declining to form such a connection with him as that so strangely proposed, than they would if, differing with him as they did upon points of the first importance, they had formed a connection which they must have known was liable and likely to be soon dissolved, and the dissolution of which, 


\section{THE FORMATION OF CANNING'S MINISTRY I5I}

whilst it brought not only their foresight but fair dealing and honour into question, could not fail to be productive of the greatest embarrassment to the King and to the public service. Nothing that has passed has at all surprized me, tho' there was no reason to apprehend that the explosion would so soon take place: but I had no doubt that it would be immediately consequent upon a vacancy in the first situation in the Government. All would have remained quiet if $\mathrm{L}^{\mathbf{d}}$ Bathurst had been the successor of $\mathrm{L}^{\mathbf{d}}$ Liverpool, and $\mathrm{M}^{\mathbf{r}}$ $\mathrm{C}$ [anning] contented to continue where he was ; but, if he would not serve under $\mathrm{L}^{\mathrm{d}} \mathrm{B}$ [athurst], what right has he or any one else to complain that others would not serve under him. . . .

(Sidmouth MSS.)

\section{Sir James Macdonald to Viscount Granville.}

20, Duke St. 2r April.-Thank you for $\mathrm{y}^{\mathrm{r}}$ note. I really wrote under the influence of feelings that entitle me to have the spirit rather than the tenor of my letter looked to by you. Among those feelings was and is one of personal remorse at having consented to sit by without making more effectual resistance to a course wh. has led to a most unsatisfactory issue, and very little consonant with his own intentions. I and some others who have more weight with $\mathrm{L}^{\mathrm{d}}$ L[ansdowne], have, since I wrote to you, taken such steps as are most likely to facilitate any resumption of communication sh the opportunity occur.

But what I am the most anxious about is that you shd have faith in his perfect sincerity and cordial good wishes to $\mathrm{Mr}$. Canning, in whom he appears to me to take moreover a warm personal interest.

$$
\text { (P.R.O., G. \& D., 29/6.) }
$$

\section{I3. James Abercromby to the Marquess of Lansdowne.}

[c. 2I April.]-The Duke of Devonshire will speak for himself. I know not how I can add anything except by commenting on the details of Canning's exposition, which I consider to stand thus. He expects Lord Wellesley to remain, he being willing to do so, but the King tired of it. He is bound to offer it to the Duke of RutlandCanning and also Lord Carlisle expect that he will decline, but you must act on the belief that he will accept. A Catholic Secretary for the present, but he intends after an interval to appoint Herries of the 


\section{I52 THE FORMATION OF CANNING'S MINISTRY}

Treasury, who, though Protestant by vote is I suspect of the colours by which he can rise, but he is very moderate and capable. The Duke of Rutland if he accepts, represents the opinions of the Duke of York ; his connection with Lord Manners ${ }^{1}$ will not recommend him, and he will bring with him friends and others not desirable. The Chancellor I suppose will be Shadwell who voted against the Catholics. Practically speaking, all this, if it should happen, would not obstruct you materially if you have the King and solid power here, for the elements are not formidable. But it might be said that the Catholic Cabinet here is balanced by a Protestant in Ireland. Joy, who will be Attorney General is Protestant, but I suppose (guess only) that North or Dogherty will be Solicitor General. The people at Brooks's are wild. I can neither approve or defend the conduct of Brougham. I am in fact very greatly annoyed by their communicating with Lord Dudley, to go of course to Canning. Those who object to your refusal will be the first to censure you for supporting or for accepting if they do not get what they want. I find since I began to write that Herries is more Protestant than I had supposed. I pity you from the bottom of my heart. If you accept, the perils are tremendous-they are no less so if you refuse. Whatever you do, insist upon the leadership in the Lords. I must further say that I distrust your facility in negotiation-recollect that a fair and reasonable stipulation for places is essential to the maintenance of your influence and your principles. The questions are, having agreed to waive pressing the Catholic question, is it sensible to refuse on smaller points, when there is a chance of future and great good. On the other hand there is a limit to concession. If you concede at all beyond what you can fairly maintain in argument, it will be lost if you succeed in emancipating the Catholics, but if you fail they will recoil upon you and increase future blame. A third question is one which relates to what will be your own position if you continue to support without office-your following and influence will be greatly diminished. If you accept you hold at least a distinct place. But if you accept I feel strongly that you ought to start with some resolution in your mind, with as definite period in view as possible, beyond which you will not keep your principles as to the Catholics in abeyance. I look upon this as an experiment to carry the question. If it fails you have made a sacrifice, which ought not to endure indefinitely. If the Duke of Devonshire is in the Cabinet, it ought

1 The fifth Duke of Rutland was the great-grandson, Lord Manners the grandson, of the third Duke. 


\section{THE FORMATION OF CANNING'S MINISTRY I53}

not to be to the exclusion of whoever you would have brought in. The Duke ought to [be] a supernumerary, though it would be in fact gain for you. Whatever you do, you may be assured there is no one who will be more cordially your supporter. God send you a good deliverance and a cool heart.

(Bowood MSS.)

\section{James Abercromby to Viscount Althorp.}

[20 or 2I April.] _ . . . Lansdowne and Canning had a very long interview. The latter gave a detail of his conduct and difficulties since he last came into office. In doing so he certainly impressed Lansdowne with a strong impression as to the difficulties he had to encounter, of the national principles of his foreign policy, and that he had only carried his points by more than one threat of resignation. He then proceeded to his present position-he stated that the King was as he thought at his worst about the Catholics . . . that if the present opportunity was improved and a fair and reasonable Government established, that he, Canning, entertained the most sanguine hopes of being able ere long to carry the Catholic question-that his own case was one which was encouraging, for when he came into office it was against the King's inclination, and yet he is now where he is-that he had been violently opposed to his system of foreign policy, and that he had been brought round and admitted that he had been wrong - that Canning was quite free as to the Catholic question but that as a matter of feeling he did not wish to press it unnecessarily. The question then came to be, what was to be done, Lansdowne and Brougham being committed as you know. The making the Catholic question a Cabinet question at this moment was a bar in limine. To depart from it even for a time is I admit a relaxation of principle and can only be justified by the good that might be done to the country. You keep out the inveterate foes of the question and of everything liberal-you give a chance for impressing a better character on the Government of the country, and what weighed more with me than all the rest was that there did appear to me to be such a chance of carrying the question, as made it in my mind pusillanimous not to run some risks for it. I think it a question of the greatest urgency because I am well convinced that delay will rather diminish or destroy the effect of our opinion. The Church of Ireland cannot stand against exclusion and when you shake so great a part of your establishment, where is the safety for 


\section{I54 THE FORMATION OF CANNING'S MINISTRY}

the rest? We thought that by consenting to delay and stipulating for the power of attempting to make it a Cabinet question, we obtained our security for our conduct-because that gave a fair opportunity to Lansdowne at a moment to be chosen by himself, either to obtain the object, or to retire. It was agreed that the Catholic question was the first object, but that being waived for the moment, the next thing was to secure a Government in Ireland composed of proper persons and not divided against each other. On this I have little or no doubt that it will go off, to the sincere regret of Canning. The truth I believe to be that the King has been driven from point after point and has at last taken shelter under the device to have a Protestant Lord Lieutenant. Personally I devoutly pray that it may fail, but for the public I shall be sincerely sorryfor either the old Tories will come back or Canning will make a very indifferent Government. My own feelings on the whole matter are these. I find Lord Lansdowne, to whom I owe great obligations, in a real difficulty, and I feel that I ought to make all the sacrifice I can honourably make to help him. . . . My firm conviction and most confident hope is that Lansdowne and Canning united would ere long carry the Catholic question and establish liberal principles. If they succeed all is well-if they fail, in my firm opinion they ought not to go on, after carrying, as they clearly would, a Catholic Bill through the Commons and losing it in the Lords. . . . I agree with Lord Holland in thinking that it is a question on which honest and sensible people may fairly differ . . . Lansdowne will, as he is bound to do, support Canning's Government as far as he canothers will do so also. Brougham declared last night that if Lansdowne did not accept office he should go into violent and factious opposition. He may, for to him nothing is impossible-but I can't reconcile that with his letter to Canning. I pray sincerely that it may all go off as I expect. Canning was to see the King at two. If nothing follows tonight from that, we are out of our difficulties-but not so the Government and the country.

[PS.] The Cabinet with two or three exceptions (the versatile Copley being one) and all places of power and patronage would have been in Catholic hands.

$$
\text { (Althorp MSS.) }
$$




\section{Mrs. Canning to the Duke of Portland. ${ }^{1}$}

Downing Street, + past $60^{\prime}$ clock, Friday, I8

[Foreign Office. 6 o'clock, 2I April]. - Pray do not be startled at the proposition I am about to make to you, and do not say no to it [up]on the first impulse. Will you consent to come into the Cabinet and lend your name as a sleeping partner [to] the firm? I put it in this shape as likely to be [a] more attractive [name] to you than an active department, tho' that would be still more useful if you could [bring] yourself to undertake it. Considering [however] the latter $\alpha$ as hopeless, the office proposed to you $\alpha$ is

for your acceptance in point of rank

that of Privy Seal, which [ranks the] second in the Government but has absolutely nothing in the way of business belonging to it, and you need not remain one hour longer in town from [filling] it, nor need you (if you do not feel disposed to do so) ever attend the Cabinet Councils while you are in town. I ask it of you as a personal kindness to me not to refuse this proposal. It will be of the greatest use in the formation of the Government to have your name as belonging to it, and if at the end of [three months] you should wish to get rid of it, you can resign. The good \& will have been in a great measure accomplished at, I trust, [a small] inconvenience to you, and with the satisfaction of having done a kind thing by us in acquiescing in the first instance. I have not time goes

before the post $\alpha$ to enter into the system upon which the Governin every essential point

ment is formed, but I think a it will be such as you will approve.

1 The text shows how considerably the letter was modified, either by Mrs. Canning or her husband, before it was actually despatched. The Harewood document is, of course, a draft. The dating of the two MSS. is most curious. Mrs. Canning's dates are not always clear, and what looks like $2 \mathrm{I}$, in the draft, may really be 20 (I have had no opportunity of checking this since I saw the MS. at Harewood House in 1934). The letter which her brother-in-law received is very clearly dated Friday, 18, but Friday was the 2oth; and the letter is endorsed, the 2oth. Moreover, Canning's letter to Dudley (No. 2or) suggests that Mrs. Canning's letter to the Duke had already been sent-that is, the previous evening. I think, therefore, the 2 oth is the correct date. 


\section{I56 THE FORMATION OF CANNING'S MINISTRY}

Lord William has already given it his approbation and promised support. Once more pray say the short monosyllable yes to yours affectionately.

(Harewood \& Welbeck MSS.)

\section{The Duke of Portland to Mrs. Canning.}

Welbeck. 22 April.-You have put the proposal contained in your letter in a manner which leaves me no option. If you tell me it will be of use to your Government that I should accept the office, I, ignorant of your views, the nature of your difficulties, \&c., have no choice but to acquiesce. I know it is an office which must be filled by somebody, although the business of it is nothing. I am aware too that it may be of great use to Canning to have somebody in it, who will not only be very ready, but very happy to resign it, the moment it may suit his convenience. I am that man. I wish him however to consider one thing before he finally determines on my taking the office for the present. Connected as we are, it is impossible that I shall not be made the channel of solicitations to him from persons from whose importunities I cannot defend myself, the moment I am ostensibly in the Cabinet with him. This will give him more trouble (of which, by the way, he will have otherwise a great deal too much) than if the office were in the hands of a person not so nearly connected with him. I beg he will reflect upon this before he determines. But I leave to him to determine as he pleases. ... .

(Harewood MSS.)

\section{Memorandum.}

[22 April.]-Lord Lansdowne's difficulty a complete Protestant Government in Ireland. He thinks that Lord Wellesley's delayed resignation would have a worse appearance; for then the appointment of a Protestant Lord Lieutenant and a Protestant Secretary would APPEAR to be his. Lord Lansdowne therefore makes a point of the Secretary being an AVOWED Catholic. He considers the Secretary as a person appointed to transact business with the Home Secretary, and to do so with a person of contrary opinion would be unpleasant to his feelings and out of the question. From respect and consideration to his Majesty he makes no objection to the representative of his Majesty's person being Protestant, 
only trusting, as he expects, that it will not be a person of bigotted or ultra principles. With regard to the lead in the House of Lords, Lord Lansdowne felt indifference and a reliance on the good understanding which he is sure would subsist between him and $\mathbf{M}^{r}$ Robinson. But he has friends who are so extremely tenacious on this point, who go so far as to make their degree of support of the Government dependent on it, that he would like some distinction to satisfy and ménager them-such as that on occasions of Addresses or subjects of foreign policy he might be employed, $\mathrm{M}^{\mathrm{r}}$ Robinson of course taking business already commenced, and on Treasury subjects; on any arrangements which would prevent Lord Lansdowne appearing to give precedency to an office inferior to his own. Lord Lansdowne feels full reliance on the honour of $\mathrm{M}^{\mathrm{r}}$ Canning to afford him the full patronage of his place, and that he will communicate freely with him on the general patronage of the Government, so as to give him the weight natural to his situation, and to the support due for the numbers of those he brings to the support of the Government. In conclusion Lord Lansdowne makes a positive stipulation that if unfortunately he should find difficulties which would compel him to resign, his resignation should be accepted without the obligation of specifying the nature of them, leaving it open to be on public or personal grounds.

(Harewood MSS.)

\section{Lord Auckland to the Marquess of Lansdowne.}

New Street. 22 April. - . . Whatever your decision may be, I am prepared to think it right and to abide by it and to defend it, for I feel it altogether to be a case of so much real difficulty, such a balance of possibility of real good and of risk of injustice and ultimate failure, that where my opinion wavers, yours will decide it. Nevertheless I must fairly say that the leaning of my opinion under all the circumstances and in the state of the negotiation is that at all hazards you ought to accept, endeavouring as far as is possible to save the principles untouched which you have. declared, and professing that your adhesion is only to last until you see real evil growing out of an Irish Government formed in a manner which you have endeavoured to avert. I need scarcely say that this is the opinion of all the clamorous and of many of the most considerate of those who have followed you in public life-an opinion however expressed by some in a manner and 


\section{I58 THE FORMATION OF CANNING'S MINISTRY}

with a violence which make one almost doubt its soundness. For one, whatever the result may be, I shall always bear witness to the painful intenseness with which in a most difficult case and where no line has been free from real difficulty, you have endeavoured to pick out the best path. No one has a right to say for another to what extent and for what amount of good a risk of loss of character is to be encountered.

[PS.] I have been talking with Holland, and do not agree with him about stipulating for an equivalent. The Home Secretaryship is an equivalent, and if you accept the more freely you do it the better-but I am much for stickling for the leadership-it is due to you, and you may buy it on your terms.

(Bowood MSS.)

\section{George Canning's Memorandum for Lord Lansdowne.}

F.O. 23 April.-I The Catholic question is to remain, as in Lord Liverpool's Government, an open question, upon which each member of the Cabinet is at perfect liberty to exercise his own judgment, in supporting that question if brought forward by others, or in propounding it either in the Cabinet or to Parliament. But if any member of the Cabinet should deem it an indispensable duty to bring forward individually the Catholic question in Parliament, he is distinctly to state that he does so in his individual capacity.

2 The inconvenience (now unavoidable) of having one open question in the Cabinet, makes it the more necessary to agree that there should be no other. All the existing members of the Cabinet are united in opposing the question of Parliamentary Reform, and could not acquiesce in its being brought forward or supported by any member of the Cabinet.

3 The present members of the Cabinet are also united in opposition to the motion for the repeal of the Test Act, of which notice stands on the books of the House of Commons. They see great inexpediency in now stirring a question which has slept for upwards of thirty years, and they could not consent to a divided vote by the members of the Cabinet upon it.

(Harewood \& Bowood MSS.) 


\section{THE FORMATION OF CANNING'S MINISTRY $\quad$ I59}

220. The Duke of Devonshire to the Marquess of Lansdowne.

23 April.-I have been kept till post time and have no decisive answer to send you yet. Canning received well my statement. He has just told me that William Lamb has accepted the Irish Secretaryship. I shall have much to tell you tomorrow, but of course I should be delighted to hear of your arrival here.

(Bowood MSS.)

\section{Lord Ellenborough to the Marquess of Lansdowne.}

Roehampton. 23 April.-In the event of your consenting to take office, will you allow me to suggest the expediency of your ascertaining directly from the King in a personal interview, before you kiss hands, what his understanding now is of the principles on which the new Administration is framed, and to what extent the Government is at liberty to use its influence for the purpose of ultimately carrying the Catholic question. I think this direct course may avoid much future embarrassment. It would be still more satisfactory if you could obtain from the King a declaration in writing, without showing any suspicion of his sincerity.

I can hardly doubt that the King in his conversation with the Archbishop committed himself to the extent of declaring that he should keep the patronage of the Church in his own hands and use it against the Catholics, and therefore I am the more anxious that upon this point you should know clearly where you are.

(Bowood MSS.)

\section{Lord Holland to George Tierney.}

Vice-Chancellor's. 23 April.-The Duke of Devonshire is come back with an answer that leads at least to negotiation and I think (should I say I fear?) to final conclusion of a treaty and acceptance of office. Lansdowne relaxes about $L^{d}$ Lieutenancy-but stipulates for Irish Sec. and a due share of patronage and in compliance with his friends for lead in House of Lords. Duke of Devonshire does not like the terms to be mentioned and I do not enumerate them till they are either accepted or refused. The result is that the answer from Bowood was a conditional acceptance and that more conditions are submitted to the King and under consideration. I adhere to my promise, ministerial support of a Ministry 


\section{I60 THE FORMATION OF CANNING'S MINISTRY}

of which Lansdowne is part and the organ in House of Lords-and I think the same motives which prevail upon me, somewhat hesitatingly I acknowledge, to support, ought to prevail on you to accept office if offered. I sincerely hope you may for your own, for George IV and for the country's sake, for the more efficient men that do, the more likely the experiment is to succeed-though as I told the Duke of Devonshire it is a hazardous and uncertain one and perhaps hardly a right one to make. Never was so scandalous a step as that of Brookes's.

Ibid. [23 April].-I have nothing in the way of news to add to my hasty scrap from the Vice Chancellor's. My belief and in some senses apprehension is that the terms will be accepted, and Lansdowne Secretary for the Home Department with a Catholic Irish Secretary and the lead in the Lords. The scandalous proceeding at Brookes's was not I think calculated to make him more compliant or add to any good which his accession could promote. There are however many graver and better authorities that will sustain him in his resolution, and the Irish members all, as well as Lord Grenville, who is a good judge on such a point, and says that the Home Office and the Irish Secretary, next to the full adoption of the measure by the Cabinet, are the points of greatest importance. There are however many great authorities the other way, and some yet more fearful symptoms which render our union with Canning's Government a hazardous step. I do not merely allude to the great publicity which the King gives to his opinion against the Catholics, of which I send you a specimen that you must return, but to others utterly unconnected with Ireland or Catholics. The change in the promotion of the army in addition to the novelty (in which I on some accounts rejoice) of a High Admiral, are considerations of no little importance. It is not clear whether Anglesey is in the Cabinet or not, but if he is there, he is so against his wishes and remonstrance, at the earnest solicitation of the King, and with the full acquiescence of Canning after he had told the latter that he disliked being there, that he concurred in scarce any part of Canning's policy, that to say the truth he had never in his life had any great fancy for him, and that he accepted a seat in the Cabinet directly from the King, thought he was there to serve and obey, and did not consider himself as personally or politically connected with his colleagues further than as serving the same Sovereign!!! The Duke of Devonshire will ask Canning whether Anglesey is in the Cabinet or no, and if answered 


\section{THE FORMATION OF CANNING'S MINISTRY I6I}

in the affirmative will ascertain if the above circumstances but how far any confirmation of such details will influence the Duke's mind or conduct, I do not know [sic]. He is manifestly and most earnestly desirous that Lord Lansdowne should join, though I think some of his house are not only more aware of but more indulgent to the objections that may be urged to it than they were. I vindicated you from the imputation of the suggestion or the supposed motive thereof. But the truth is that Lansdowne had undesignedly omitted to state the difficulty about a Catholic Lord Lieutenancy as strongly as Canning had done, and introduction of such a stipulation in a written answer was both in appearance and reality more of a direct and not very courteous rejection of the whole overture than we were aware or than Lansdowne intended. For that reason though for no other, I am not sorry that the negotiations are renewed, though I should rejoice at their going off on any other point. The lead which would be the most popular in our House and I think in the country will I suspect be patched up if not conceded.

Now to ourselves. I adhere to my determination of supporting to the full extent of a Ministerial man any Administration in which Lansdowne is Home Secretary and of which he is the organ in the House of Lords. I will give the experiment as far as I am concerned a fair trial, though $I$ own and think it hazardous and doubtful, and perhaps scarcely right. I see no distinction in such ministerial support and taking office, in principle. Personally there are some distinctions in my case, and without stating them all, for they are nice and require much explanation, that of my pledge on the Test Act is quite sufficient to place my case and yours entirely on a different footing-and though I am not so precluded as the Observer makes me by literary and domestic habits from ever being a Minister, yet the health and business of my family are likely to oblige me soon to go abroad possibly for a time or to a distance inconsistent with official duties.

None of these difficulties apply to you. It is, I think, essential to the success of the experiment that some of those who showed reluctance to make it, should have office in the House of Commons. Above all, if Lansdowne were left entirely at the mercy of those who have hurried him into consent and had no other official representatives in the House of Commons, I do not think we should be acting kindly or even fairly by him. I would not urge you, my dear Tierney, to act in any way that, situated as you are, 


\section{I62 THE FORMATION OF CANNING'S MINISTRY}

I would not act myself, but selfishly I should personally feel myself more comfortable in my ministerial support when represented in the Commons by you and in the Lords by Lansdowne, than if by the latter alone. There is no man who has substantially sacrificed so much as yourself during a long political life to friendship and to principle. I really think that withdrawing from office and public life now, because you love Grey, think [sic] there is much force in some of his arguments, but do not partake all his feelings, would not be chivalry but folly [sic]; and as to principle I can only repeat that the same considerations which make me put it in abeyance for the chance of a great good in supporting my friend in the House of Lords might without impropriety induce you to join an Administration where Lord Lansdowne and the Duke of Devonshire are embarked, for the purpose of defending it in the Commons.

$$
\text { (Tierney MSS.) }
$$

\section{William Cockburn to Robert Peel.}

[23 April.]-After I left you this morning I called at the Admiralty and saw Sir George-who immediately began lamenting your secession from the Government. I told him that I equally lamented it-but that the Catholick question seemed to be the great stumbling block that could not be got over. He said-he had understood that Canning made no point thereof. I told him I had not seen you-but that I shd like to know if he $\mathrm{c}^{\mathrm{d}}$ with propriety ask the question how far Canning w $^{\mathbf{d}}$ pledge himself upon that question. That he must understand that I had no kind of authority to ask anything in your name-but that still if he $\mathrm{c}^{\mathrm{d}}$ learn Canning's sentiments on the matter, I w $\mathrm{w}^{\mathbf{d}}$ take an opportunity of communicating them to you if Canning wished it. In the course of the day Sir George saw Canning and asked him the question as coming from me-and Canning told him that if it were possible to reconcile you to his Government he $\mathrm{w}^{d}$ do everything that $c^{d}$ be done consistent with honour, and beg'd that I w tell you so-but that if you refused to entertain the subject when I saw you-he beg'd this conversation might be quite confidential. He did not seem startled when Sir Geo. asked by my desire whether he $\mathrm{w}^{\mathrm{d}}$ give up the Bishops, but till the ice was broken with you, he $c^{d}$ not say any more. The negociation with the Whigs is yet in suspense. Let me earnestly entreat therefore that you will 


\section{THE FORMATION OF CANNING'S MINISTRY I63}

consider the state of the Kingdom before you determine to shut the door to this accidental overture. You are a much better judge than I can be of the possibility of bringing this matter to a happy issue. But if you will at all listen to my proposition, I cannot but think that rather than throw the power of the State into the hands of the Whigs (which must be the consequence of your refusal) Canning $\mathrm{w}^{\mathrm{d}}$ make every concession which you $\mathrm{c}^{\mathrm{d}}$ require. If you are determined to accept no terms, just give me a line, and I shall merely inform Sir George that I could do nothing with you ; but if, for the sake of the country and for the sake of the Protestant Church, both of which I think you may save-by coming again into power-you determine to try whether an arrangement may not yet be made with Canning to your satisfaction, send for me either tonight or early tomorrow morning, and I will enter into more details with you.

[PS.] Pray burn this letter.

(Add. MS. 40394, ff. 24-7.)

\section{Robert Peel to William Cockburn.}

Whitehall. 23 April.-I lose not a moment in expressing my regret that you have had any communication with Sir George Cockburn respecting me. I will thank you to inform him that it is not possible to reconcile me to $\mathrm{Mr}^{\mathbf{r}}$ Canning's Govt upon any terms, and above all make him understand that I was no party to your communications with him this morning. I must say upon matters of so much delicacy and so deeply affecting my character, I would rather that my name was not mentioned in the way it has been without my consent.

PS. I shall be much obliged to you to communicate this note or at any rate the substance of it without delay to Sir George Cockburn.

(Add. MS. 40394, ff. 28-9.)

\section{William Cockburn to Robert Peel.}

[23 April].-I am extremely sorry for your note. You are plunging the country and the Church of England into certain ruin by your present conduct. But of that you are the best judge. Only observe that your name was not used at all this morning. Sir George distinctly stated that I had not seen you, but that from 


\section{I64 THE FORMATION OF CANNING'S MINISTRY}

my own head I had enquired what were Mr Canning's intentions. I shall communicate the ill success of my effort to Sir G. C. early tomorrow morning-but most gladly sh ${ }^{\mathrm{d}} \mathrm{I}$ hear from you (if possible) again before I see him. Pray destroy the note of this morning that at least the whole matter may rest in complete oblivion.

(Add. MS. 40394, f. 3o.)

\section{John Rickman to Lord Colchester.}

Palace Yard. 23 April.- . . . The Speaker, I find, declined the proffered office of Home Secretary as too great a sacrifice of a safer office, but with expressions of goodwill to the new Premier and the expected Cabinet. ...

$$
\text { (P.R.O., G. \& D. 9/18.) }
$$

\section{Viscount Dudley and Ward to the Earl of Aberdeen.}

Park Lane. 23 April.-Canning has proposed to me to go to the F.O. till the end of the session. Though I feel how monstrously above my strength even the temporary occupation of so great an office must be, yet I have not thought myself at liberty to decline it. Perhaps too I feel some curiosity, once in my life, to have a peep at official life. In three months I cannot do much harm to the publick, nor to myself. Be it as it may, " jacta est alea," and I shall pass this spring in the tread-mill, along with several notorious offenders.

I did not write to you during the late troubles, because I was absent from London, and anything two days old that was said upon event[s] passing so rapidly, must have been quite stale and inapplicable.... I hope you are not going into opposition, though considering who are gone out, I am not sanguine as to the support the new Government is to receive from you. The negociation with Lansdowne is not over, but I do not understand that at this moment it is in any very hopeful way. I am not however acquainted with the latest details. I shall greatly regret the failure of it.

$$
\text { (Add. MS. 4323I, ff. 228-9.) }
$$




\section{THE FORMATION OF CANNING'S MINISTRY I65}

228. The Duke of Wellington to the Marquess of Londonderry.

S. Saye. 23 April, 7 a.m.-According to your account the negotiation appears terminated to the satisfaction of the two parties.

I don't see any objection to your publishing this over again, but I don't think its republication will do any good. I assure you that I don't want to protect the gentleman from any thing that any body chooses to write of him. The object of my letter to you respecting the Duke of Newcastle was to warn the Duke of the consequences of making unauthorized statements of a conversation with the King, and to recommend to the aristocracy a measured and moderate conduct in the difficult circumstances in which they are placed.

(Londonderry MSS.)

\section{Charles Arbuthnot to William Huskisson.}

Whitehall Place. 23 April.-As I learn that all your concerns are now settled, I hope that my successor is named. It is of importance to me to know who it is, for being very poor I am anxious to ascertain whether I am to leave my furniture or to take it with me. In the latter case I shall hire an unfurnished house. . . It is no concern of mine, but I do assure you it is of some consequence whom you appoint to this office. The Treasury have so completely made us bankrupt and have taken such steps to enable us to pay the bills for Buckingham House, that much may be hereafter disclosed if you shd send here a new associate who may hereafter tell the secrets of the prison house. Milne will fully explain to you in what a state our finances here are, and how strongly I have privately remonstrated with the Treasury upon the course they were pursuing. But as I began by saying this is no concern of mine, and all I wish to know is who is to be my successor, I have thoughts of going out of town for a few days.

And now, my dear Huskisson, hoping truly that you are better, and trusting that a junction with the Whigs may make you as happy in office as I feel in leaving it, I have only to add that in all the chances and the changes of this strange life I shall never cease to wish for $\mathrm{y}^{\mathrm{r}}$ happiness.

$$
\text { (Add. MS. } 3^{8} 749 \text {, ff. } 2 \text { IO-II.) }
$$




\section{I66 THE FORMATION OF CANNING'S MINISTRY}

\section{William Huskisson to Charles Arbuthnot.}

Som Place. 23 April. Private and Confidential. (Copy.)-If I could inform you by whom you are to be succeeded, I should certainly not make any mystery where there ought to be none. But in fact I have not to this hour ever once heard any one named as your successor; indeed, to say the truth, I have never asked the question; but, if any appointment had been made, I think I should have heard of it. Neither have I heard that all our arrangements (I mean of the Cabinet) are, as you suppose, settled, which may perhaps be the reason why I am unable to say who is likely to be your successor. What may be the issue of the negotiation with Lord Lansdowne I am sure I cannot foresee; but this, I know, that if the King is driven to look for counsel in new quarters, the step was not taken till every expedient had been exhausted to retain in his service those who had hitherto been in his Cabinet, or to procure the assistance of others who had concurred in the general policy of the late Administration.

I could have wished to have said a few words on a topic touched upon in your letter from Woodford, I mean the periodical Press. To that Press, and to all connected with it, I am, and always was, a stranger. At the same time I am convinced that it has been under no special influence since the late change. That it has been encouraged or countenanced, in speaking disparagingly of the D. of W., is what I utterly disbelieve. For myself I can only say that I have nothing more at heart than to contribute to allay all unpleasant or angry feelings wherever they exist, and to see the D., if he declines political life (a point on which I have no right to urge anything) in his proper place as a soldier. As the soldier who has served the country, I wish to see him directing its military energies, and presiding over its military character. $\mathrm{He}$ is the guardian of that character in the eyes of the world; a world jealous of our greatness; and if I have one personal wish which I feel more than another, it is that the means may speedily be found of replacing in his hands a trust so important to this country. I write as an individual, and speak my sentiments to you as a friend without reserve. God speed them and you ; and saying this in all sincerity, I remain, [etc.]

$$
\text { (Add. MS. } 38749 \text {, ff. } 213-14 \text { ) }
$$




\section{THE FORMATION OF CANNING'S MINISTRY}

\section{3r. Charles Arbuthnot to William Huskisson.}

Whitehall Place. 24 April. Confidential.-Many thanks for your letter. We had been led to believe, it appears erroneously, that all the Cabinet arrangements had been finally settled; and it was on this account that I asked who was to be my successor. I dare say that this day will not pass over without all parties being agreed.

There are some parts of $\mathrm{y}^{\mathrm{r}}$ letter on $\mathrm{w}^{\text {ch }} \mathrm{I}$ wish to make an observation or two: but I give you my word of honour that what I shall say will proceed exclusively from myself and will never even be mentioned to the person principally concerned. I know, and it has always been gratifying to me to know, that you appreciate the Duke of Wellington as I do ; and were this not known to me, it would not have been possible for me to have written to you about him. You say that your new allies $\mathrm{w}^{\mathrm{d}}$ not have been taken, had not every expedient been exhausted to retain in the King's service those who had hitherto been in his Cabinet. I think, from what I have seen and heard, that this is quite correct with respect to all, save only the Duke of Wellington. I will say nothing of Canning's first letter to the Duke, because (although in its style and expressions there was a formality I had never seen before) I have heard that it was intended to be cordial and that a mutual friend had seen it before it was sent. The Duke's answer to that first letter was written from an anxiety to avoid giving offence. It was allowable to the Duke, as it was to you all to determine whether, Canning being Premier, the seat in the Cabinet shd be given up or retained; and as the Duke knew that it was far from being the invariable practice that the individual who was charged to form an Administration was to be considered as the head of it, he had an earnest desire to ascertain with certainty under whom it was that he was asked to serve. There may be a variety of reasons, not in the least offensive, for declining to serve under any particular individual, and whether the Duke's decision was right or wrong, he had, I am free to confess, made up his mind to retire from the Cabinet if Canning was to be at the head of it. The Duke feared, I believe, that on some main points of our policy he might differ from Canning; and I think you must have seen that such are his notions of subordination as $\mathrm{w}^{\mathrm{d}}$ make him very unwilling to thwart or oppose the Prime Minister. But the Duke's retirement from the Cabinet did not lead by any necessary conse- 


\section{I68 THE FORMATION OF CANNING'S MINISTRY}

quence to his begging the King's leave to resign also the command of the army. This unfortunate act, and unfortunate on all accounts I deem it, would have been prevented if some mutual friend had seen Canning's second letter as well as his first. Of the second letter I will only say that most certainly it was not written in the spirit of kindness, and it was made still more unacceptable by the signification in it that it was sent by the King's commands. Upon the subject of the correspondence I will say no more. I hope what I have said has been temperate; and sure I am that my heart is in unison with yours in the wish you express that angry feelings may be allayed. But can we avoid feeling that it is far more easy to prevent total separation than in any way to reunite what has once been severed asunder? I feel with you that both at home and abroad it has been essentially important to see the Duke at the head of our army. But the head of the army must be more or less in connection with the Minister; and supposing that I am right in feeling that ground for offence was given to the Duke, would it, I ask you, be practicable, that he and the person who offended him should act cordially together? And more than this, it is to be borne in mind that when men separate in politics new arrangements are formed; and those who, in consequence of the separation, are taking the same line may become so linked and united, that no step can be taken by one unless approved of by the others. All this might and would have been avoided if the treatment of the Duke had been more courteous. You who have been in Cabinet with the Duke have known his merits and his value, but I agree with you that the dire calamity of all is the loss of his services at the head of the army. Most truly do I wish that I saw a chance of his being again in that situation from $\mathrm{w}^{\mathrm{ch}}$ nothing but the sense of improper treatment removed him; but I confess to you, and I confess it with sorrow, that I see no chance of that taking place $w^{\text {ch }}$ you state to be so desirable, and in which sentiment I unite with you most cordially. I beg you to consider what I have written as proceeding wholly and solely from myself. It is a gratification to me to feel that whatever happens, all between you and me will be as it has been, and I can assure you with truth that under all circumstances you will ever find me most truly $y^{\text {rs }}$.

PS. Since writing my letter I have heard that the negociation with the Whigs is at an end. I may have been misinformed, but so I have heard. I must think this to be a fortunate result for the country, and fortunate I should also say for all of you who 


\section{THE FORMATION OF CANNING'S MINISTRY I69}

are forming the new Government. More than ever I must now lament that there was not some kindness in the style and manner of the last communication with the Duke, for notwithstanding the abominable falsehoods respecting him, and particularly as to his communicating directly or indirectly with Lord Grey, you must be well aware that he who has for ever so risked his life for his sovereign, is not the man to be factious in his retirement. Never forbearance equalled his when he resolved upon keeping his case to himself, tho' assailed by all his friends to put to shame the scurrilous abuse so heaped upon him; and I believe that he is almost the only man who $\mathrm{w}^{\mathrm{d}}$ have gone into the country in order to be far removed from everything like opposition to his Majesty. And yet this is the man, great and glorious as have been his services, whom evil friends to Canning $\mathrm{w}^{\mathrm{d}}$ strive to lower in the estimation of the world. When all is settled I will call on you as an old friend.

$$
\text { (Add. MS. } 38749 \text {, ff. 216-23.) }
$$

\section{George Canning to the Marquess of Lansdowne.}

24 April.-Considering the near approach of the meeting of Parliament, and being precluded by your Lordship's distance from town from the advantage of an interview, I think it best to address directly to your Lordship in writing, the answer which I have to return to the memorandum which the Duke of Devonshire has been so kind as to communicate to me, of what passed between his Grace and your Lordship the day before yesterday. I have given the fullest consideration to the principal stipulation on which your Lordship feels it necessary to insist as the condition sine qua non of your Lordship's acceptance of the office of Home Secretary of State-viz., "That the Secretary to the Lord Lieutenant of Ireland shall be an avowed Catholic." The spirit in which all our intercourse has been carried on, and the very nature of the office which has been tendered to your Lordship's acceptance, will be sufficient guarantees to your Lordship that my difficulty in complying with this stipulation does not arise from any want either of entire confidence in your Lordship or of a desire to meet your wishes. It rests on wholly different grounds which I will explain to your Lordship with the same frankness which you do me the honour to admit has marked my former communications.

In executing the charge graciously confided to me by his Majesty, 


\section{I70 THE FORMATION OF CANNING'S MINISTRY}

it was my duty as well as my desire to endeavour to represent in the composition of the Ministry, that neutral character in respect to the Roman Catholic question which his Majesty declared his determination to maintain in his Government. The secession of almost all those of my former colleagues who hold opinions opposite to mine on that question, and the refusal of others agreeing with them in those opinions, to whom I made application, disenabled me from executing his Majesty's commands to their full extent in this particular. His Majesty was graciously pleased to accept the will for the deed, and to acquiesce with undiminished confidence in the plan of a Cabinet in which, supposing your Lordship to have joined it, there would have been ten members professing opinions favourable to the settlement of the Roman Catholic claims, and only two who are opposed to them. His Majesty however at the same time was pleased to declare his desire, that upon the appointment of a new Irish Government, it should be composed of individuals holding the opinion so unequally represented in the Cabinet. As it is not intended to bring forward the Roman Catholic question as a Government measure, anything which should excite in Ireland an expectation that it would be so brought forward, could not but be productive of inconvenience, if not of mischief. The greater part of the argument in the last debate on the Catholic question turned on this very consideration. It was alleged that the indirect encouragement held out to the Catholics at the Union-that subsequently his Majesty's visit to Ireland-that the appointment of Lord Wellesley to the Government-were all so many incitements to hope, which ought to have been carefully withholden if there was not a settled intention of realising that hope within a definite period. The appointment of a Cabinet in which the numerical preponderance is so greatly in favour of the Catholics would perhaps be a more direct incitement to hope than any of the foregoing, if it were not qualified by some reservation in respect to the composition of the Government of Ireland. In opposition to this reservation, your Lordship makes a point that one of the component members of the Irish Government, viz., the Secretary, shall, as matter of absolute stipulation, be an " avowed Catholic." After what I have said, I trust your Lordship will not take it amiss if I feel that both my duty to the King, and my own conscientious opinion forbid my adopting such a stipulation. After the confiding and generous manner in which the King has sanctioned the proposed distribution of Cabinet offices, I could not bring myself to submit 


\section{THE FORMATION OF CANNING'S MINISTRY I7I}

to his Majesty any limitation of his Royal discretion upon a point (and the only one) which his Majesty has specially reserved. My inability to yield this primary point to your Lordship makes it unnecessary for me to state any of the difficulties which would occur upon other points of the Duke of Devonshire's memorandum. I hope I need not say with what feelings I receive the assurance which his Grace was empowered to convey to me, of your Lordship's disposition to support, out of office, the Administration of which it was my earnest wish that you should form a part. But if your Lordship under these circumstances has felt it indispensable to refuse office, need the same self-denial extend to your friends? Would it not be a just return to his Majesty's gracious proofs of confidence to your Lordship, that the Duke of Devonshire, whom his Majesty has directed me to invite into one of the highest posts of his Majesty's Household, should be encouraged to comply with that invitation-that $M^{r}$ Scarlett, to whom, with the same authority (and with the entire concurrence of Sir N. Tindal) the place of Attorney General has been offered, should accept it-and that it should be open to any other individual connected with your Lordship, who may be not indisposed to act with a Government which they and you approve, to testify that approbation by taking office? I feel this wish most particularly with respect to the Duke of Devonshire, whom his Majesty has through life distinguished with his gracious regard-upon whom his Majesty is now most desirous of conferring this mark of his favour-and who is now for the first time in his life not precluded by difference of opinion with his Majesty's political servants, from entering into his Majesty's family.

I have to ask your Lordship's pardon for having suffered myself to be betrayed into a topic with which in strictness I have no right to trouble your Lordship, but I hope to find my apology in the openness and unreserve which have prevailed in our late communications, and in the reluctance with which I find myself obliged to relinquish the hope which I had entertained of our official connection.

(Bowood \& Harewood MSS.)

\section{Lord Binning to Sir Charles Bagot.}

Colonial Office. Tuesday [24 April].-You will be in a tantarum if you do not hear, so I write though I have nothing to say except 


\section{I72 THE FORMATION OF CANNING'S MINISTRY}

what is rumour. Lansdown having retreated to Bowood re infectâ on Friday night or Saturday morning-bold Devon pursued him thither on Saturday night-\& return'd on Sunday night. The consequence of his journey is that the thing is on again. It was asserted yesterday that all was settled-but that's a lie. All was not settled. Today it has been asserted that all is off--but I suspect that to be a lie too. There is I suspect a point of honour about the Irish Governt - that creates difficulty \& there is also a difficulty about leading the Lords, Robinson's friends \& Lansdown's being it is said tenaces propositi. Whether this latter point has actually been brought into debate I know not--but I am very certain that they have been contending to beat down Canning in his wish to carry into effect the King's wish that the Irish Govern' should not be Catholic. Whether they are still contending about that or not I know not. But the thing is not I believe settled-and as little do I believe it to be off. There is a schism among the Whigs about the whole thing-Grey-Tierney-Duncannon-\& they say Holland being adverse-the Duke of Devon-Carlisle et altri-especially Burdett \& Brougham!!!! being very for. . . .

(Bagot MSS.)

\section{George Tierney to Lord Holland.}

Cassiobury. Tuesday [24 April].- . . . I cannot say that what you tell me sharpens my appetite for office, but perhaps I may be saved a world of trouble by not being offer'd anything. You will observe that from the beginning of this business I have never had any sort of confidential communication made to me, nor, with the exception of what passed on Friday night, have I once been consulted about any part of what has been going on. If the $\mathrm{K}$. were even neutral on the Catholic question, he who held the seals of the Home Dept. need care little about the Lord Lieuty of Ireland, but when H.M. avows himself violently anti-Catholic and stipulates for a Protestant $L^{\mathbf{d}}$ Lieut ${ }^{t}$, he can only mean to provide himself with a check upon the Home Secretary instead of the Home Secretary being allowed to controul the Irish Govt, and so I fear Lord L[ansdowne] will find when he makes the experiment which is proposed. That experiment you seem however to think will be made. I wish Lord L. may never repent the eagerness of those who have made him change his course. From what you say, I conclude he will have conceded to him the lead in the $\mathrm{H}$. of Lords, 


\section{THE FORMATION OF CANNING'S MINISTRY I73}

but if that should not be so, I much fear his political reputation will not gain much by his promotion. His whole strength must then depend on his share of patronage. As to Lord A[nglesey] being in the Cabinet I own it will not in the least surprize me, expecting as I do every day to hear of some additional proof of the game which $[$ he] is playing. . . .

(Holland House MSS.)

\section{John Hope to Robert Peel.}

Edinburgh. 12, Moray Place. 24 April. - . . . The Lord Advocate and myself were placed in a very embarrassing situation. We separately formed the same opinion-that we ought not to resignan opinion in which we were strengthened by every consideration applicable to Lord Melville's interests and confirmed by every statement we have seen of the grounds of his resignation-as not affecting us, I mean. One difference exists in regard to the case of the Advocate and myself-tho' on a point not involved I suppose in his determination. I have always been since I was a boy a zealous Catholic on that unfortunate question, and indeed have been long known to be so by $\mathrm{M}^{\mathrm{r}}$ Canning. But I believe that the Lord Advocate did not think that his conduct should depend on his opinions on that question. I trust that our determination will not be viewed with disapprobation by you.

(Add. MS. 40393, ff. 262-3.)

\section{The Duke of Devonshire to the Marquess of Lansdowne.}

F.O. Tuesday [24 April].-Mr Canning has shown me the letter which he has written to you. I have read it with great regret, and the appointment of William Lamb will make the grounds of refusal appear awkward. I entreat you to come up directly, and to have an interview with $\mathrm{M}^{\mathrm{r}}$ Canning. It cannot fail to be satisfactory on both sides whatever the result may be. I have urged $\mathrm{M}^{\mathrm{r}}$ Canning to omit the part relating to myself, but he will not, as the King insisted on it. You know my intentions, but I must repeat them and authorize you to say that it is my own determination not to accept of office on terms which have led you to decline it. ...

(Bowood MSS.) 


\section{I74 THE FORMATION OF CANNING'S MINISTRY}

\section{The Marquess of Lansdowne to the Duke of Devonshire.}

Bowood. $24 A$ pril.-Many thanks for your letter which leads me to expect a decisive result tomorrow. As I could not in any case leave this place till the middle of the day, I shall receive it here, but if it should be such as to justify my assuming that all is right and favourably disposed, I shall think it my duty to set out immediately, so as to enable me to see Mr Canning at an early hour the following morning. Should it however prove otherwise I shall be glad to remain here another day or two.

PS. I have received a long letter since you were here from Baring, one of the most sensible men, quite disposed to join me with all his family in a co-operation with Canning, but at the same time dwelling with great apprehension on the particular difficulty which has occurred, as one very difficult to get over.

(Chatsworth MSS.)

\section{Earl Spencer to the Marquess of Lansdowne.}

Althorp. 24 April._. . . You are aware that my opinion is so decided on the superior importance of relieving the Catholics from their disabilities above every other question which can at present arise in the politics of this country, that, ever since we quitted office in 1807 , it has always appeared to me impossible to resume it without making the concession to the Catholics a sine quâ non condition. In this view of the matter I should willingly have concurred in advising any sacrifice which could be required to secure the attainment of this object, and therefore on the present occasion, if it appeared that it was likely to be secured by forming part of an Administration of which Mr Canning was to be the head, my advice would undoubtedly have been to take office; and it would have been given the more willingly from the circumstance of all the other measures of any importance to which he appears to be pledged being such as I have approved, and am ready to support. I might go a little further, and say that even under the expectation that it might not be found advisable to press the immediate adoption of the great measure, I could have consented to acquiesce in its postponement for a short time, provided the ostensible formation of the Cabinet and especially of the Irish Government, indicated a favourable disposition to its being ultimately carried. On these grounds (if I were personally in question, which I am not) I should not have thought I 


\section{THE FORMATION OF CANNING'S MINISTRY $\mathbf{I 7 5}$}

was acting inconsistently with the principles I profess, in acceding to such a Government, and of course in advising the accession of others to it. But I cannot conceal from you, my dear Lord, that (though rather imperfectly informed as to particulars) I am apprehensive that the present arrangement will not be quite of the above description, and that circumstances have transpired as belonging to it, which place the hopes of carrying the Catholic question at as great a distance as they were under the Administration lately dissolved; and though I am satisfied that in yielding, if you have yielded, to the suggestions of those of our friends to whom you have alluded, you have adopted what has appeared to your mind the least of the evils presented to our view on this occasion, the result will be less satisfactory than I could wish it to be, both to yourself and to the public interests. Having said thus much, in the confidence that you will receive the freedom of my observations, as proceeding from the sincere regard I entertain for you, I will only add my hearty good wishes, and my hope that the measures in general of the new Government may be such as may justify me to myself in giving them all the little support I am able to give, and which I should seriously regret being obliged to withhold from a Government in which you have consented to take an active part.

(Bowood MSS.)

\section{Charles Wynn to George Canning.}

Whitehall Place. 24 April, 5.40 p.m.-I called upon you just now being extremely anxious to speak to you upon the draft which Robinson by your desire communicated to me, and to suggest to you my doubt whether it does not too plainly anticipate Lord Lansdowne's rejection of the overture, when practically the condition, for which he contends is (at least in the present instance) fully conceded. I think too well of him to believe that he can still struggle for the recognition of an abstract principle the application of which may never come into question. Would it not then be better rather to assume that the appointment of William Lamb will satisfy him, than to intimate an opinion, that as you cannot in terms comply with what he seems to consider a sine qua non, the negotiation must be at an end?

(Harewood MSS.) 


\section{I76 THE FORMATION OF CANNING'S MINISTRY}

\section{The Countess Cowper to The Hon. Frederick Lamb.}

London. 24 April.-I have so many things to say that I hardly know where to begin and new events so constantly succeed each other that if one has heard any piece of news half a dozen hours ten to one but what some change has taken place. This is now the posture of affairs. Lansdowne is again listening to terms and the negotiation is going on so that we have all great hopes of its succeeding. The thing he first objected to was the Orange complexion of the proposed Irish Government, but this is in a great measure removed by $L^{d}$ Wellesley's remaining there for the present and $\mathrm{W}^{\mathrm{m}}$ going as Secretary. Another difficulty is whether Robinson who is to be in the House of Lords will allow him to have the leadership. $L^{d}$ L[ansdowne] himself don't much care for this but his friends insist on it and certainly as the organ of a great party he ought to have it. $L^{d} \mathrm{~L}$ [ansdowne] himself does not much like coming into office at this moment but all his party are violent for his doing so, even those who are in general the greatest democrats- $-L^{d}$ Sefton, Ld $^{\mathbf{d}}$ Tankerville, Brougham, Wilson. They feel that it is everything for the Catholics and that by a refusal the House of Commons must fall back upon the Torys-or if C[anning] is forced out it will be still worse for the Catholics since there must be then a strong AntiCatholic Governt. Lord C[arlisle] is violent for his accepting and the eagerness amongst the Whigs is quite extraordinary. Lord Grey alone stands upon the other tack and has I believe only $L^{d}$ Rosslyn and one or two more followers. He thinks by standing out that C[anning] would go to the wall and that the Whigs might come in alone upon their own terms or make a coalition with $\mathrm{D}$. W[ellingto]n but this is to my mind absolute folly-and dividing Parliament at [sic] the Catholic question will be a constant bar between them. $\mathrm{L}^{\mathbf{d}} \mathrm{H}$ [ollan]d is full of crochets about some precedents in $\mathrm{I80}$, and cool about L[ansdowne] accepting but still he advises him to do so ; and though he says for particular reasons he will not accept office himself that he will sit behind L[ansdowne] in the House and follow his leading as implicitly as he would have done his uncle's-in short the whole party have behaved in the most beautiful and disinterested manner. Brougham is quite wild for $\mathrm{L}^{\mathrm{d}} \mathrm{L}$ [ansdowne] to accept, and says he will follow his leading in everything but that for himself he will take no place either political or legal, in short it seems as if the prospect of office had brought everybody to their senses, while the loss of it has deprived the Tories of theirs. They have no bounds to 


\section{THE FORMATION OF CANNING'S MINISTRY I77}

their rage or their language, there is nothing they dont say at White's that the $\mathrm{K}$. ought to be in a $\mathrm{s}$ [trai]t waistcoat and everything personal and violent they can think of against him and C[annin]g. $L^{d}$ Auckland says this bad behaviour of the Tories makes the Whig conduct for the last 20 years shine out with great advantage and ought to make one admire their patience and forbearance. Duke $\mathrm{W}$ [ellington] is alone the point that grieves us all and is a general mourning-how could he be so foolish!-it was either a bit of temper or the suggestions of that roguish Chancellor who wished with himself to pull down the whole edifice like Samson when he drew the columns down-I am afraid they all thought by the sudden resignations to frighten the King and by bullying to bring him to their own terms ; if so their having failed in this attempt is doubly provokingI can feel little doubt this was the case since Henriette going to see Mrs Ar[buthno]t [?] the day they had resigned heard all the story from her-and then she added, Ce qu'il $y$ a de plus curieux c'est que nous rentrons tous demain. H.'s answer was " mais vraiment il ne valait pas la peine de sortir pour si peu de temps-however the calculation was wrong - and I think always a mighty foolish one, for I do not at all think $\mathrm{H}^{\mathbf{y}}$ [sic] a person to be bullied in this way-on the contrary he is always ready to get on his high horse when he is offended. The Duke's desertion has grieved him very sincerely and on both sides there is at this moment much angry feeling but I hope in time we may see all right again and the $D$. be in the place he was so well fitted for, in which he is in truth quite necessary. I am very glad the $\mathrm{K}$. keeps it for the present in his own hands because this allows of a return. If there had been another appointment it might have been a difficulty his giving up the Ordnance, and the Cabinet was right and natural but the Army was independent of any Governt and having received it from the $\mathrm{K}$. he ought to have looked upon it as such, and I am quite sure that when I saw him the morning I left town, Thursday week, he intended to give up the former places, but had no idea of losing the latter. He dined yesterday at $L^{d}$ C[onyngha]m's, St George's Day and tho' he tried to be in spirits I saw so evidently how vexed and how uncomfortable he was that I could have cried with all my heart. Besides he looks so ill-and it is such a false move ! one does not see how he can with credit hearken back and yet I am so sure that he cannot be happy without place and patronage, a thing he has so long been accustomed to. I am sure it must be that villain the Chancellor who has led him on and made a tool of him and that fool Mrs $\mathrm{A}$ [rbuthnot] who has worked 


\section{I78 THE FORMATION OF CANNING'S MINISTRY}

him up. $L^{y}$ Con[yngham] is very much grieved about it for she is sincerely attached to him and would do anything in her power to make up the breach but at present of course nothing can be done. If Lord L[ansdowne] comes in he will have three places in the Cabinet- $\mathrm{L}^{\mathrm{d}}$ Carlisle Privy Seal, some man I think as Master of the Mint-and the Duke of D[evonshire] Lord Chamberlain-Scarlett will $\mathrm{I}$ believe in any case be Attorney General, and $\mathrm{W}^{\mathrm{m}}$ take his. Of course he seems very much pleased and even more by the manner of the offer, he was asked as a favour to take it because the K.'s wish being for a Protestant in that place, his regard and liking for $\mathrm{W}^{\mathrm{m}}$ would make him pass over that want of qualification. He is also come into Parlt for Newport, ${ }^{1}$ the borough C[annin]g has just vacated, on very reasonable terms. $L^{d} \mathrm{P}$ [almersto]n is to keep his present place and to have a place in the Cabinet, so that he is very well pleased. There are only three Protestants in the Cabinet out of II or I3 so that I think we have no cause to complain; these are Anglesey, Copley, Bexley-the two first having been Catholics and very likely to turn again. The only fear one has now is of $\mathrm{L}^{\mathrm{d}} \mathrm{L}$ [ansdowne] refusing and deranging the whole thing but even in this case C[annin]g would have almost all the Whig support, and the $\mathrm{K}$. has had inessages from some Tory potentates to say that they would support his Govern ${ }^{t}$ whatever it was. The fact is that these people are so shabby they always must come round and try to get on the right side.-The $\mathrm{K}$. has behaved remarkably well in the whole thing, a very decided and strong prejudice against the Catholics which is kept up by his sister and the bishops and the recollections of his father and brother, but still he is willing to consider as much as he can, and of course his determination is a good deal kept up by the anger he feels against those who have deserted him - he is very

1 On 24 April. Three days later Herries, the Secretary of the Treasury, wrote to T. Sewell, who, apparently, was Lord Yarborough's election agent : ... "I have however to inform you that in consequence of an arrangement which it was not possible to make before the election of Mr. Lamb, he is now appointed to an office [the Irish Secretaryship] which will render his re-election necessary. I hope that the peculiar circumstances of the present occasion will satisfy Lord Yarborough and the Trustees that the trouble and inconvenience which may be occasioned by such an immediate re-election of $\mathrm{M}^{\mathrm{r}} \mathrm{Lamb}$ has been unavoidable and that they will therefore have no objection to it. The writ will be moved as soon as Parliament meets " (Herries MSS.). Herries wrote to Lord Yarborough on 7 May: "... I presume that it may on the whole be more satisfactory to your Lordship that another person should be returned on this new vacation of the seat for Newport than that $M^{r}$ Lamb should have been re-elected . . ." (Ibid.). Lamb was returned for Bletchingley on 7 May. 


\section{THE FORMATION OF CANNING'S MINISTRY $\quad$ I79}

anxious for $\mathrm{L}^{\mathrm{d}} \mathrm{L}$ [ansdowne] and $\mathrm{I}$ believe feels great satisfaction in the prospect of returning to his original friends. Those who have resigned regret it very much now, and I believe feel they are very likely never to return. It was to be sure a miserably bad calculation, for if that party ever returned to power they would certainly look out for more efficient members of Govern ${ }^{t}$ than such old cobwebs as have been swept away-Westmorland, Bathurst, Arbuthnot. $\mathrm{L}^{\mathbf{d}}$ Granville so much disliked being kept at the Foreign Office even temporarily and having to speak in the House of Lords that C[annin]g has let him off and taken Dudley instead and he was yester[day] presented to all the Foreign Ministers. The idea of him in that place is very ridiculous but of course C[annin]g will do everything, and four months hence when the Session is over he will return to the place and fix some other individuals in the Treasury and Exchequer departmentally as he calls it, and making the Foreign Office the head situation-what power that man has-and all his plans succeed. How tired you must have been all this time waiting for the arrangements and what will be your opinion now and what will be your own move. . . . Duke W[ellington] told me yesterday that he should write to you and he thought by the common post, whether it is to tell his story or anything else I don't know.--and as we were at dinner and amongst enemies I was only anxious to avoid any but public conversation, for you know he is not the most prudent of men. I would give anything to see him in his place again and contented. I am so fond of him but he has not acted wisely on this occasion-and if I had been at his elbow I should have prevented him. What a pity that he was not in love with me instead of Mrs A[rbuthnot]. The moral of the story is that no man should be in love with a foolish woman, if he is ever so clever himself he is sure to be ruin'd by it. I have just seen Mrs Huskisson but have heard nothing more.

(Broadlands MSS.)

\section{I. James Abercromby to the Marquess of Lansdowne.}

[c. 24 April.]-How it is to end God knows, but I hear there is a messenger ready to be despatched to Bowood, which looks like acceptance. If the object is to bring you to town I join heartily in it. Every possible consideration combines to make that a very desirable event, and the sooner you come into personal contact with Canning the better. The length of time that has elapsed since 


\section{I80 THE FORMATION OF CANNING'S MINISTRY}

Canning became Prime Minister wearies the public, and if you are to be together, the sooner you get to business the better. . . . It is clear that the offices of Premier and Chancellor of the Exchequer will be vacant at the end of the Session, as Lord Dudley holds the seals ad interim for Canning. This opens a chapter in which you either have heard or no doubt will hear something. It is material and may make a vast difference in the whole transaction. As to persons let me say that Mackintosh is in a condition that deserves [illegible] if possible. Why not be Judge Advocate? I should think that would do well. I had much rather that it was with him than with me. It is a situation in which I could be of no sort of use to you. I have no doubt there will be abundance of suitors and I think it for your good and that of the cause that you should apply what you have for others as far as you can. Let me wait-that is all for the best, and I speak sincerely. I think, but it is only guess, that the Duke of Devonshire would be very glad to waive his seat in the Cabinet now, if you take your friend, especially if it be Lord Carlisle, as the supernumerary for the moment. But remember, I have no sort of authority for that. It may be doubtful what will be the fate of Tierney-look upon his being otherwise provided for than in the House of Commons as a possible case. I mention this that you may be prepared. Brougham's case is really very pressing and it is very essential to counteract as soon as possible the suspicion of any permanent personal exclusion. I wish that something could be settled between you and $C$ [anning] in that matter so that his feelings, which have been dreadfully excited, may be allayed. A friendly communication from you is quite essential, and if from Canning also, so much the better. Don't be afraid about the Home Office. I think I can show you how to make even a short time in it creditable to yourself and useful to the public.

[PS.] Rice says that Lord Donoughmore writes warmly for the junction. So does O'Driscol. (Bowood MSS.)

Ibid.-I wrote you a few lines an hour ago believing that the negotiation would end in their accepting your terms. I find that it is not so. In the first place I think that you will agree that if those who met at your house had been aware that the King really stipulated for a Protestant Government in Ireland, all or nearly all would have been of opinion that we could not accept. Is the case changed? It is in appearance but not in reality. It is true that Mr Lamb is appointed and that Lord Wellesley remains-that is practically against your view of the case. But I suppose that the King should 


\section{THE FORMATION OF CANNING'S MINISTRY I8I}

become less cordial towards his Ministers-that the Tories and the Church should get round him, may he not at any moment insist upon the performance of his pledge? If he does where is your resource but in compliance or resignation? If you comply, must you not lose the assistance of the Catholics and the public? If you resign, will not the King ask, did you not accept, giving me this pledge? What is your answer? If the public ask, why did you accept office under a pledge to the King which you never intended to redeem ? You can only say, I hoped to overcome the objections of the King, in other words we hoped to evade the pledge. This will not, as it appears to me, stand the test of argument - it is not fair dealing. I had rather have a less Catholic Government in Ireland upon a distinct and honest understanding, than run the risk of getting more by management. Further, although I perfectly admit that a Catholic Cabinet in England is a great gain to the Catholics in the balance, yet it in fact reorganizes and perpetuates the system of balance and division in a very objectionable form. You will not like what I am going to say, but my opinion is that for your own sake, you ought to come up to town without delay.... (Ibid.)

\section{The Marquess of Lansdowne to George Canning.}

Bowood. Wednesday morning [25 April].-I have just received your letter of yesterday's date by a King's messenger, with feelings I cannot say of personal disappointment, but of sincere regret that it should oppose an obstacle to my giving that official support to your Government to which you have been so kind as to attach greater value than it deserves, and which it would be my own strong inclination to afford. I cannot however disguise from myself that the arrangement proposed as I understand it, is one which, however flattering to me as a mark of his Majesty's approbation and confidence, is peculiarly unfortunate as connected with my own feelings of honour and consistency. It is calculated (though not I am sure intentionally) to make it appear to the public of England and more especially of Ireland as one of the first, perhaps the first act of my official character to recommend replacing a Lord Lieutenant and a Secretary friendly to the Catholic claims by two persons of opposite opinions. By such an act I should forfeit any little hope I might now have of my name being useful to the Administration with which it was connected, by the confidence it might inspire in Ireland. I must confess without further explanation I find it difficult to 


\section{I82 THE FORMATION OF CANNING'S MINISTRY}

reconcile the reasons urged in favour of a Government uniformly Protestant in Ireland with the proposed selection of Mr Lamb for the situation of Secretary which, were his appointment to be considered as permanent, would remove in a great degree the difficulty which I feel on this branch of the subject. To any other difficulties which might be found to exist, it is not necessary for me to advert at present, as they are not specified; but upon the topic with which your letter concludes (advice suggested to be given to friends in general and to some persons in particular) I may be permitted to say that it involves mixed considerations of too delicate a nature to be committed to paper, but that I am on the point of returning to London, and that if you have any desire to confer with me on that or any other subject connected with the future support of your Administration, I shall be most happy again to communicate with you personally, in the same spirit of frankness and cordiality which has hitherto prevailed, and with a perfect reliance on your honour and intentions, however unfortunate the result may have proved of the particular arrangement which has been suggested.

[PS.] As the expression of " avowed Catholic" as applied to the Irish Secretary is twice adverted to in your letter, I beg to add that although it was the phrase I believe I used and correctly noted from our conversation by the Duke of Devonshire, I should, had I put my sentiments on paper, [have] said more generally, " a person known to be favourable to the consideration of the Catholic claims."

(Harewood MSS.)

\section{The Marquess of Lansdowne to the Duke of Devonshire.}

Bowood. 25 April.-I have received Mr Canning's letter without the smallest degree of personal disappointment, as I think you know and believe, but with regret as far as I had brought myself to think that a junction would have been useful to his Administration and to its character here and in Ireland, but even that utility depends upon preserving one's own character and consistency of action. We must not disguise from ourselves that it is proposed to throw upon those who accede to the Government and more particularly upon myself, the responsibility of changing as the first act of their power a friendly Lord Lieutenant and Secretary for two persons hostile to our opinions, and without our being able to give the Catholics any other proof of our influence in their favour. There is a point beyond which feelings of honour and consistency of conduct cannot be waived for considera- 


\section{THE FORMATION OF CANNING'S MINISTRY I83}

tions even of public expediency if admitted to be such. It will always be a satisfaction to me to think that you did not consider me as unreasonable either in my feelings or my wishes; and as you express so strong a desire that I should return to London, I shall set out in the course of a few hours so as to be there very early tomorrow ; nor can I have the slightest objection to see $\mathrm{M}^{\mathbf{r}}$ Canning again if he desires it, as I am confident no difficulty originates with him. I write to him fully and frankly by the messenger.

(Chatsworth MSS.)

\section{George Canning to Sir William Knighton.}

F.O. 25 April, $\frac{3}{4}$ P. II.-I have just seen Scarlett. He accepts the Attorney Generalship, whatever may be the decision of the Whigs. Lord Lansdowne is sent for up to town, and is expected this afternoon. It may probably therefore be late in the day before I have occasion to trouble his Majesty. The Duke of Devonshire is to be at St James' at two, unless he should hear to the contrary from you. His Majesty may make use of Scarlett's example with the Duke of Devonshire. (Harewood MSS.)

Ibid., $\frac{1}{2} p$. II $[p . m$.$] . - I omitted to mention in my note of this$ morning that Lord Fitzwilliam approves of Scarlett's acceptance, and returns him again for Peterborough. This too might have its weight with the Duke of Devonshire. (Ibid.)

\section{The Earl of Harrowby to George Canning.}

25 April.-It has just occurred to me that if the Mint is not wanted for promotion, it will be well bestowed upon Plunket, who might also take charge of the Privy Council appeals. This would leave the Master of the Rolls at more liberty for House of Lords appeals.

(Harewood MSS.)

\section{George Canning to Charles Wynn.}

F.O. 25 April. Copy.-Before we look for any other successor to Lord Amherst, I think it due to you to ask you whether you have any views upon that succession yourself, and to assure you that if you have, I shall be most happy to endeavour to ascertain (without committing you) how far the Court of Directors would be disposed. 


\section{I84 THE FORMATION OF CANNING'S MINISTRY}

to concur in them. But pray keep this question and the answer to it (whatever it may be) to yourself.

(Harewood MSS.)

\section{Lord Holland to the Marquess of Lansdowne.}

25 April.-If the treaty be concluded and distribution of favours and offices begun, there are points which must have occurred to you, but which you may wish to be reminded of.

With a view to the general interests of the Government, and to give your branch of it due weight in the Commons, I may, I hope, add, from friendship to me and as a mark of the value set on his and my support, you would I am sure secure a post of honour and profit for Tierney.

Men of your weight and importance never form and seldom join a Ministry without stipulating for some peerages. There are now I hear to be four-Robinson and Plunket-Copley and Abbot-the two first, Canning's, the two last, the King's. Are you to have none? Possibly it is deemed right to keep the balance that every Catholic peer should have his Protestant pendant, but then in fairness you should have had your portion of the Catholic moiety.

There may however be new peerages without disturbing that balance-that is to Scotch and Irish representative peers-and I always think that the former when they have talents, fortune and party attachment have prior claims to all others from the precarious nature of their seat in the Lords. Probably your friend Rosebery looks to one-and Charlemont certainly did. Neither of these would disturb any balance, and if I did not stickle I would at least apply for them. I need not add that I have spoken to neither of them. Rosebery I hardly know. Charlemont in I807 asked me to press for a peerage for him. I told him if he continued to act with us, and the Whigs either remained or returned to office, it would be almost a matter of course, but that I could not then urge it. Should you therefore get it for him I should like my testimony to be mentioned to him as among your motives for the application.

On the subject of peerages I suspect but do not know that one would be acceptable to Burdett. The offer could not but pleaseand his pleasure conciliates large classes of persons, not to speak of the pleasure it would give you to please him.

You will perhaps smile when I say that I also suspect that a peerage is the object of Lambton's ambition. Could it be offered, 


\section{THE FORMATION OF CANNING'S MINISTRY I85}

or could a question be put by those in possession of power to Grey on the subject, I believe it would gratify in a quarter where I from friendship and all your supporters from policy should most wish to disarm hostility or propitiate favour. Kinnaird is young, but a promise in case of vacancy of support for the Scotch peerage would be gratifying to his father's friends. These are hints. As to myself, with the exception of what regards Tierney I have nothing to ask. If you do anything for Charles, ${ }^{1}$ I should rejoice, and, if of a nature to bring you through him in contact with the Duke of Clarence, it might in certain contingencies be of service to the public. It is certainly the shape in which favour would be most acceptable to me, but I am indifferent about it and should be miserable to harass you with any inconvenient request.

(Bowood MSS.)

\section{The Earl of Carlisle to George Canning.}

Grosvenor Place. 26 April.-I would have endeavoured to have seen you for two minutes yesterday, to have expressed to you my sincere satisfaction with the communication made to me by Lord Lansdowne. Personally speaking, the Privy Seal is a higher flight than I could reasonably aspire to. I need not repeat that it has been my object, and ever will be to contribute whatever may be in my power to facilitate the arrangement of your Government. . . . (Harewood MSS.)

\section{George Canning to Sir John Leach.}

F.O. 26 April.-Mr Plunket having finally declined the office of Master of the Rolls, I have received the King's commands to propose to you the succession to that office. Your coming into the House of Commons or not will depend upon your own decision. Should you wish it, I shall be most happy to find the means of placing you there.

(Harewood MSS.)

\section{A. Sir John Leach to George Canning.}

26 April.-[Accepting the office of Master of the Rolls, and declining a seat in the House of Commons.]

(Harewood MSS.)

${ }^{1}$ His son. 


\section{I86 THE FORMATION OF CANNING'S MINISTRY}

\section{William Sturges-Bourne to George Canning.}

Thursday evening, 26 April.-I have endeavoured in vain since we parted to persuade myself that I might execute the duties of the Home Department without discredit to you as well as to myself. But I feel my first opinion to have been correct. And though I should certainly be anxious to relinquish the office almost as soon as I had learned my task, yet I cannot disguise from myself that such a speedy surrender of the post would look very like a proof of my insufficiency, when I know and feel that such an opinion would be well founded. Under these circumstances I think it may be convenient to you that I should relieve you from any suspense respecting me, without my waiting to hear from you again. I am vexed with myself for not being able to comply with any wish of yours, but am sure that any facility which my acceptance of office would give to your arrangements, would be more than counterbalanced by having such a situation inadequately filled. I sincerely hope that a better arrangement may present itself to you.

(Harewood MSS.)

\section{George Canning to William Sturges-Bourne.}

F.O. $26 \mathrm{April,}$, Ir.30 p.m.-I must beg to see you tomorrow at $\frac{1}{2}$ past Io. My Administration WHOLLY depends upon your helping me for two months as Home Secretary of State.

(Harewood MSS.)

\section{The Marquess of Lansdowne to George Canning.}

Lansdowne House. Thursday night, ro o'clock [26 April].-As it will be necessary that I should accompany the result of my consideration and communication with some fere persons on the arrangement we talked of today, with some explanations and remarks (though none I think that will create difficulty) I am ready to wait upon you with it myself either late tonight (II o'clock) or at any early hour you will name tomorrow. Were I to attempt to write upon the subject, it might only occasion additional delay. [Endorsed: " Received at Ir.3o p.m."]

(Harewood MSS.) 


\section{THE FORMATION OF CANNING'S MINISTRY I87}

\section{George Canning to the Marquess of Lansdowne.}

F.O. 26 April, $\frac{1}{2}$ p. II p.m.-I receive only this instant your Lordship's letter dated Io o'clock. I fear it would be too late now to appoint a meeting for tonight. I shall be happy to receive your Lordship as soon as you please after ten tomorrow morning.

(Harewood MSS.)

254. The Marquess of Lansdowne to the Duke of Devonshire.

Berkeley Square. Thursday evening, 26 April.-I have seen Tierney who consents to come in with me when it is expedient. I see no difficulty in your accepting now provided it is understood and intimated to the King, to Canning, and the public as part of an arrangement pressed upon you by your political friends, and with an intention of resigning it if it does not after a time completely take effect. I have been obliged to see several persons this evening, which only leaves me time to add that I shall write to Canning tonight and see him again if not tonight tomorrow morning early.

PS. Duncannon approves decidedly of the arrangement in its present form and enters exactly into my feelings about it.

(Chatsworth MSS.)

\section{John Allen's Memorandum.}

26 April. - $L^{\mathrm{d}} \mathrm{L}$ [ansdowne] returned from Bowood this morningunderstands from Canning that the King is bent on offering the $L^{d}$ $\mathrm{L}^{\mathrm{y}}$ to the $\mathrm{D}$. of Rutland on $\mathrm{L}^{\mathrm{d}}$ Wellesley's removal, which however is not to be for some time - and that Canning is afraid to remonstrate against the appointment lest it shd break up the whole Administration. $L^{d} L$. unwilling to be Home Sec ${ }^{y}$ when this offer is made, \& wishes therefore to postpone for some time taking office, but to advise his friends to accept at present. William Lamb proposed as a stopgap. Tierney to have the Mint if he will take it before $L^{d} \mathrm{~L}$. is in office. Scarlett has been advised to accept being Atty Gen ${ }^{1}$. Canning offers to have stopgaps for those who decline till $\mathrm{L}^{\mathrm{d}} \mathrm{L}$. is in office. D. of Devonshire, $\mathrm{L}^{d}$ Carlisle, $\mathrm{L}^{d} \mathrm{~L}$ [ansdowne] and Tierney to be of the Cabinet. Robinson will also in this way take the lead in the $H$. of $L$. before $L^{d} L$. takes office. 


\section{I88 THE FORMATION OF CANNING'S MINISTRY}

27[th]. Letter from Ld L. at I p.m. Arrangements to be postponed till after session as settled yesterday. $D$. of $D$ [evonshire] to. accept at present, but conditionally.

(Holland House MSS.)

\section{George Tierney, jun. to Sir Charles Bagot.}

S. Row. 26 Aprit.-I did not write to you last post for I could have told you nothing beyond the conjecture and the rumour of the day, and even now I have nothing certain to communicate. I trust however that before tonight everything will be settled, and that I shall finish this letter tomorrow in a clearer way than I have begun it. It is now just a week that this negotiation with the Whigs has. being going on, that is to say, with the Whigs as a body, properly socalled, for I fancy one or two of our loudest talkers have been laying themselves out for an opening of this sort for the last month : they tell me it is a pleasure to hear the beautiful things $\mathrm{Mr}^{\mathbf{r}}$ Brougham has. said about Mr Canning, and the equally beautiful ones which he has. been paid in return. Others have contented themselves with running about the streets and crying "Canning for ever." I will own. to you, and I am sure you will forgive me for saying what I think, though your view of the thing may be different from mine; I will own to you that as a Whig, a bitter Whig if you please, I cannot join in all this vociferation, much as I admire Mr C.'s talents, and heartily as I rejoice in the ousting of the old Chancellor, \&c. \&c. I cannot shut my eyes to the facts that $\mathrm{M}^{\mathrm{r}}$ Canning is not Prime Minister, that the King is all in all, and that the new Administration are met and thwarted by him at every turn, that the appointment of Copley is a very humiliating proof of weakness, and, lastly, that if the hands of justice, or any other casualty were to overtake Sir W. Knighton, the $\mathbf{K}$. would turn round, when no longer kept straight by that peculiar influence, and invite his faithful servant $\mathrm{Mr}$ Canning to retire quam citissime. The particular points at issue in the pending negotiation are I fancy being rapidly smoothed away, and it is more than probable that tomorrow's sun may see what it has not seen for many a year, the Whigs in office. I wish with all my heart the thing may answer, and that they may be able to effect a real and firm coalition with Mr Canning, to the utter exclusion of Tory persons and Tory principles. . . . What do you say to $\mathbf{L}^{\mathbf{d}}$ Dudley being pro tempore a man of business? I expect to hear every morning that he has run away. All the world says Mr Canning is to return to the F.O. 
immediately, and I am glad of it for there he is indeed unrivalled. . . . $\mathrm{M}^{\mathrm{r}}$ Plunkett has acted wisely in giving up the Rolls : it was a strange appointment, and gave great offence to the English Bar. Scarlet is Attorney General, at which I believe all the world is well pleased.

27 April.-All is not yet settled, but I fancy the principal difficulties have been got over, and that the result will be the taking of office by a certain number of the Whigs. Leach is Master of the Rolls. William Lamb goes Secty to Ireland, where $L^{d}$ Wellesley remains for the present. $L^{d}$ Anglesea is I believe to be in the Cabinet. ... .

Private. 4 p.m.-I open my letter to say all is settled, and upon what I consider the best possible terms. Office is not to be taken immediately, but if all goes on well, that is to say in plain words, if matters connected with Ireland, \&c. \&c., are satisfactorily explained and dealt with, the Whigs then will form an ostensible part of the Administration, the places to be so held, being I fancy already marked.

\section{(Bagot MSS.)}

\section{The Marquess of Lansdowne's Memorandum.}

Undated.-It being understood that the Irish Government must necessarily be remodelled in the course of a short time, are the arrangements for that purpose open for discussion in the Cabinet ?in the same manner as any other question. Did the King direct any communication respecting the intended constitution of the Irish Government to be made to those to whom the accession was proposed ? If the former question is answered in the affirmative and the latter in the negative, a verbal understanding with $\mathrm{M}^{\mathrm{r}}$ Canning and Lord Goderich that there is an intention to resign if those arrangements don't prove satisfactory, may be sufficient.

(Bowood MSS.)

\section{George Canning to the Duke of Portland.}

F.O. 27 April.-A thousand thanks for your kind answer to Joan's letter. I am obliged to take advantage of your permission, and to request that you will, if possible, be in town on Monday next, to receive the Privy Seal, of which I will relieve you after the session. Once again, thanks. 


\section{I9O THE FORMATION OF CANNING'S MINISTRY}

PS. I do not want to keep you in town on Monday. You can return to Newmarket after kissing hands, and even if for any reason (even a Newmarket one) it is very inconvenient to you to come up, let me have a line to say so- $\&$ I will excuse you to the King. The Whigs do join-but not till after the session.

(Harewood \& Welbeck MSS.)

[Mrs. Canning wrote, the same day :] I am still unable, contrary to my expectation, to announce to you the final arrangement of the whole Governt. Mr C. wrote a letter to Lord Lansdown yesterdaywhich he ( $\mathrm{Mr}^{\mathbf{r}} \mathrm{C}$.) considered as final-but so many of $\mathrm{L}^{\mathrm{d}} \mathrm{L}$ [ansdowne]'s party have risen up in rebellion against his stipulations \& imaginary points of honor \& difficulties that $M^{\mathbf{r}}$ [Canning] has been requested not to consider the negotiation as finally broken off until they have had an opportunity of once more referring to $L^{d} L$ [ansdowne]-and for that purpose his friends have sent for him to come to town-but as he is at Bowood he cannot arrive till this eveng. What will be the result of an expressed opinion of the majority of his own party against him one cannot foresee-nor do we so much carefor excepting the D. of Devonshire-who would be a great acquisition- \& who is very desirous of accepting the Lord Chamberlain's place if he were not pledged to $\mathrm{L}^{d} \mathrm{~L}$ [ansdowne] we should perhaps lose as much as we should gain by a large accession of the Opposition. $\mathrm{M}^{\mathbf{r}}$ Scarlett is to be the Attorney General - whether any others join or not-and he accepts with $L^{d}$ Fitzwilliam's full consent \& approbation. Many others have likewise offered their support either in or out of office. The only important office which remains now to be filled is the Home Secretary of State and if $\mathrm{L}^{\mathrm{d}} \mathrm{L}$ [ansdowne] does not come in I believe it will be Mr Lamb that will have it. This is all that I have to say today. I am afraid again to promise for tomorrowbut I think it must be decided one way or other in the course of tomorrow.

(Welbeck MSS.)

\section{The Marquess of Lansdowne to George Canning.}

Berkeley Square. 27 April.-I am obliged to you for the copy of the Minute [No. 2I9] which I had not an opportunity of considering yesterday. The Test Act I consider as disposed of by the arrangement as it now stands, as all discussion upon it will be over before it can take effect. The question of Parliamentary Reform does not 


\section{THE FORMATION OF CANNING'S MINISTRY I9I}

touch me, both because I am in the House of Lords, and because I have never delivered an opinion on any general view of that subject ; but I trust you will allow me to urge you strongly not to ask $\mathbf{M}^{\mathbf{r}}$ Tierney to undertake to oppose it, as it will answer every practical purpose that it should not be brought forward or supported by any member of the Cabinet, and I should be surprized if he could enter into any stipulation so strong as the particular word I have referred to would imply. No person will feel more than yourself how much is due to the regard every man must have for his own consistency where the practical object can for the time be attained; and I have thought it best to call your attention to the subject without communicating with Tierney, whom I have not seen yesterday, when I had not possession of the Minute. I should have mentioned this morning that Tierney will expect you to send to him when you are ready to see him.

(Harewood MSS.)

\section{George Canning to the Duke of Devonshire.}

27 A pril.-I have received the King's commands to inform your Grace that his Majesty has been pleased to select your Grace for the office of Lord Chamberlain of the Household, vacant by the resignation of the Duke of Montrose. . . .

(Harewood MSS.)

\section{6r. Lord Binning to Sir Charles Bagot.}

[? 27 April.]-All settled. Lansdown not in now-but probably before very long when Robinson['s] lead has been hallow'd by priority of occupation. Scroggs ${ }^{1}$ is to be in the meantime Secretary of State for Home Department. Duke of Portland I believe Privy Seal. Canning has put the concerns of Scotland into my hands$\&$ I am to be peer'd after this session. ${ }^{2}$

(Bagot MSS.)

1 Sturges-Bourne.

${ }^{2} \mathrm{He}$ had been thought of as a Lord of the Treasury. Herries wrote to T. Sewell on the 25th : "Since I saw you, an arrangement has been concluded by which Lord Binning, member for Yarmouth, will become a Lord of the Treasury. Mr Canning desires me to express his hope that Lord Yarborough and the Trustees will not object to the re-election of Lord Binning on this 


\section{I92 THE FORMATION OF CANNING'S MINISTRY}

\section{Sir Francis Burdett to the Marquess of Lansdowne.}

St James's Place. 27 April. - . . . Yesterday I had an interview with $\mathrm{M}^{\mathrm{r}}$ Canning, and it is good you should know, and but justice to him to say that he appeared to me to open himself with the greatest and most unreserved candour. . . . He made on my mind the most favourable impression and quite satisfied me of his having done everything, and of his desire to do anything that remained in his power for the accomplishment of that union with you, upon which, I feel convinced, every hope of public good being effected solely rests. I think also I may venture to say that such is the feeling of the most independent members of the House of Commons, and of those more particularly and independently attached to you. Indeed, so strongly is this felt that it is my belief that should the negotiation be broken off except upon very different grounds than any yet stated, and more especially upon any matter of etiquette or leadership, which must fall to you as naturally as ripe fruit falls to the ground, and still more upon anything relating to patronage, all political adherence of every sort will be entirely and for ever broken up. ...

There is another consideration which I forget whether I mentioned it or no in my last, and which has with me the greatest weight. One don't like to speculate upon such subjects, at the same time a wise man will not leave them out of his consideration. I mean future contingencies. $\mathrm{M}^{\mathrm{r}}$ Canning's health is precarious. Should it fail and he be obliged to retire, the succession necessarily almost devolves upon you at the same time too that you possess the present King's mind. You also possess that of the next heir to the Crown. I see therefore the perspective of a long course of honourable and glorious conduct, a career open to honourable ambition which has seldom offered itself to any man, and never, I speak seriously, to one more worthy and more capable of profiting by it than yourself. . . .

(Bowood MSS.)

occasion. The writ will be moved as soon as Parliament meets again . . ." (Herries MSS.). And on the 27th : "Pray do me the favor of informing Lord Yarborough that there will be no occasion for Mr Canning availing himself of the offer to re-elect Lord Binning at present. His Lordship is not to receive the appointment proposed" (ibid.). 


\section{THE FORMATION OF CANNING'S MINISTRY I93}

\section{Lord Rosebery to the Marquess of Lansdowne.}

Piccadilly. 27 April.-I hope you will think that the long acquaintance which has subsisted between us, and the sincere friendship and regard which I have uniformly felt for you, warrant me both in offering my congratulations on your accession to the Government, and, as one who have supported in Parliament your political principles and conduct, in expressing a clear conviction of the soundness of your judgment in determining to form a junction with the new Administration, however anxiously we, who are friends to our great national measure, must wish that it had been founded upon a different principle with relation to it, and with a more distinct recognition of the necessity for that measure being ultimately carried.

You know, I trust, too well, how much I feel above even the appearance of insincerity to suppose that I affect to place as a secondary object of this letter the request which it cannot be thought, I should hope, in any light, improper in me to submit to your kind consideration. It is that you will exert the power which you are about to possess, in recommending me to the King for a British peerage. To $\mathrm{M}^{\mathrm{r}}$ Canning (although but very little personally known to him) I still flatter myself such a proposition will not be unacceptable ; and I am persuaded, there are other members of the Cabinet who would be happy to record my pretensions to this honour, and to befriend me on the present occasion. ${ }^{1}$...

(Bowood MSS.)

\section{George Canning to Lord Binning.}

28 April.-I have considered and inquired much, since you spoke to me the other day, about Sir William Hope's pretension to be made a Privy Councillor. The thing is quite impossible, and would lead to consequences both at the Admiralty Board and in other departments of the Government which would be in the highest degree inconvenient.

I have a great esteem for Sir William Hope's character : and if he had not long ago waived his seniority (as I understood) by leaving the chief management in the hands of Sir G. Cockburn, he might perhaps have had some ground of claim to be the Privy Councillor-whom it is now thought expedient to name. But I have long ago, under the

${ }^{1}$ He was given a British peerage in January 1828 . 


\section{I94 THE FORMATION OF CANNING'S MINISTRY}

understanding that Sir G. Cockburn was the managing Naval Lord, named him to the King. I cannot possibly change or add to that nomination. ...

(Harewood MSS.)

\section{Sir James Macdonald to the Earl of Carlisle.}

2o Duke Street, Westminster. 28 April.-We have overcome Abercrombie's reluctance-he sees that he cannot succeed for Mackintosh, and he agrees to take it himself with liberty to retire, either if the expected accession to the Ministry does not take place, or if circumstances $\operatorname{sh}^{\mathrm{d}}$ occur (wh. betw ${ }^{\mathrm{n}}$ ourselves in the event of the return of the $\mathrm{D}$. of Wellington he anticipates as possible) to make the office disagreeable for him to keep. I cannot tell you the importance I attach to this appointment taking place, for every body's sake. I have put the whole state of the thing in the most favourable manner to Ld Lansdowne, but still $I \mathrm{c}^{\mathbf{d}}$ not fail to observe the surprise excited by the bare suggestion of the office placed by Canning at $\mathbf{L}^{\mathbf{d}} \mathbf{L}$.'s disposal having been put out of his power witht further communication with him. I do hope and trust it will be found not too late to make good the appointment wh. we already know $w^{d}$ be satisfactory to the King. The very circumstances stated by Canning of the Judge Advocate's constant intercourse with the King makes it of an hundredfold more importance who the individual may be, \& this $L^{d}$ L. particularly feels. Pray carry this point to prevent mischief. I am sorry to add that he will not hear of any scheme of making way for Mackintosh, for he says first that Canning is quite right in insisting upon parly attendance, $\& \mathrm{t}^{\mathrm{t}} \mathrm{w}^{\mathrm{d}}$ make it absurd to offer it Mackintosh, and secondly that my going with him into office is one of his inducements to accept. In short the thing $w^{d}$ have been off if $I$ had pressed the mode of providing for Mackintosh just now.

(Castle Howard MSS.)

\section{Sir James Graham to the Marquess of Lansdowne.}

Grosvenor Place. 28 April.-I have been absent in Cumberland until this morning, but I had determined from the first to follow whatever course your better judgment might select in this junction of difficulty and importance. From my entrance into Parliament I have considered you the safe depository of those principles to which 


\section{THE FORMATION OF CANNING'S MINISTRY 195}

I honestly adhere and to which power in your hands is best calculated to give effect. Experience has confirmed this early confidence ; and I gladly embrace the opportunity of stating my readiness to be guided in my public conduct by your advice, and to act under that person in the House of Commons who may be considered the accredited leader of your friends. If it be your wish that I should support the new Administration, I am only desirous that it should be known I do so as your follower, convinced, that you will seek the best mode and opportunity of bringing into full operation those opinions, which no sacrifice has ever tempted you to renounce. It is possible that owing my seat to a popular election I may be compelled by a sense of duty to give an occasional vote in favour of particular measures, which it may not be expedient for a Minister of the Crown directly to sanction ; but my general adherence to your policy will be firm, and, I trust, not less beneficial from being disinterested and sincere.

(Bowood MSS.)

\section{Lord Auckland to the Marquess of Lansdowne.}

28 April. - . . . My opinion of the leadership rests upon the fear that without it you would stand as the head of a Department only, and not in the station which is your due in the Cabinet, and it would provoke a sneer. Lord Grenville's answer on a former occasion when asked who was to be first in the House of Lords was very short, "The one who speaks best," and I do not fear the result resting here. Five minutes conversation with $\mathrm{M}^{\mathrm{r}}$ Canning would probably set this at rest. . . . Fazakerly has just been here with tears in his eyes entreating me to encourage you forwards. I can say no more and I shall be satisfied with the result, whatever it is.

(Bowood MSS.)

\section{James Abercromby to Viscount Granville.}

Saturday night, 28 April.-When I spoke to you this afternoon it was under the influence of an opinion which I hold very sincerely, that no considerations of personal interest ought to find place in a decision with respect to the acceptance of office, when the common objects can be advanced. But the more I reflect on the consequences. of the arrangement made for Scotland, the more I feel the acceptance of office painful, because, necessarily accompanied with a real sacri- 


\section{I96 THE FORMATION OF CANNING'S MINISTRY}

fice of character. If I was free, I should not hesitate under existing circumstances as to Scotland to reject at once the best office in the King's gift. You may judge how I feel in accepting, under the pressure of circumstances over which I have no control. If the office of Judge Advocate be open and it is wished that I should take it I entreat you to secure for me the opportunity of stating personally to $\mathrm{M}^{\mathrm{r}}$ Canning the feelings I have on the subject. If the office be given, it may still be of use to Mr Canning's Gov to put him in possession of the inevitable effects which will flow from the measure. In such arrangements Scotland is a small object, but still those who are connected with it must look after their characters and you may be assured that there are others who see the matter not less strongly than I do. Pray excuse my troubling you with these detailsunless the truth be stated and made known, the evil will speedily be beyond the power of redress.

$$
\text { (P.R.O., G. \& D. 29/6.) }
$$

\section{Henry Hobhouse's Diary.}

Saturday, 28 April.-As soon as Canning failed in forming a Ministry from among his own party, he opened a negociation with $L^{d}$ Lansdowne for the junction of himself and a few of the more moderate Whigs. $L^{d} \mathbf{L}$. first declined, on the ground that his experience required that he shod take the lead of the Ho. of Lords, $\mathrm{w}^{\text {ch }}$ had been given to $\mathrm{L}^{\mathrm{d}}$ Goderich ; next on the ground that no anti-Catholic was to be admitted into the Govt of Ireland; afterwd ${ }^{\mathrm{B}}$ he consented to ask the opinions of $\mathrm{L}^{\mathrm{d}}$ Spencer, $\mathrm{L}^{\mathrm{d}}$ Fitzw[illia]m and others of his party. $L^{d}$ Grey with some of the more violent of the older Whigs objected in toto to support a Govt framed on the principles required by the King. But the great bulk of the party readily laid aside all considn of principles, and were only -divided in opinion as to the terms on $\mathrm{w}^{\mathrm{ch}}$ a junction shod be formed, the elder part thinking that some 4 or 5 offices shd be immediately filled by Whigs, the younger ones holding it to be immaterial how many obtained present possession, and relying on their being able to improve gradually to their advantage a footing once obtained. The latter opinion ultimately prevailed, and yesterday the Cabinet was provisionally fixed as follows, it being admitted that it is to be revised after Parlt is prorogued.

$\mathbf{M}^{\mathbf{r}}$ Canning-Premier, $\mathrm{I}^{\text {st }} \mathbf{L}^{\mathbf{d}}$ of Treasury and $\mathrm{Ch}^{\mathbf{r}}$ of $\mathbf{E x c h}$. Lord Chancellor-Lyndhurst. 


\section{THE FORMATION OF CANNING'S MINISTRY}

$L^{d}$ President- $L^{d}$ Harrowby remains.

Ld Privy Seal-D. of Portland, who has voted in opposition, tho' brother in law of $\mathrm{Mr}^{\mathrm{r}}$ Canning.

$\mathrm{M}^{\mathrm{r}}$ Sturges Bourne-Home

$L^{d}$ Dudley-Foreign temporary.

Ld Goderich-Colonial.

$M^{\mathrm{r}}$ Huskisson $\}$ Wynn retain their old situations.

$\mathrm{L}^{\mathbf{d}}$ 'Palmerston retains his office of Secretary at War, but takes a seat in the Cabinet.

So that the only Whig actually in the Cabinet, and he is scarcely considered such, is the $\mathrm{D}$. of Portland. The D. of Devonshire is to be Lord Chamberlain, and these two Dukes with the Duke of Leeds, who is to be Master of the Horse, are destined to receive the 3 vacant Garters. Mr Lamb, a zealous anti-Catholic [sic] is to be Irish Secry, so that the King must have departed entirely from the terms he imposed on $\mathrm{Mr}^{\mathrm{r}}$ Canning. Whether he was sincere in imposing them, or whether he is convinced of the necessity of departing from them, or whether he has tacitly acquiesced with a secret intention of subverting the Administration thus formed against his will, the event alone can prove. Should it be that the King has no such secret design, and that Mr Canning is to remodel the Ministry after his own liking during the recess of Parlt, there will be easily found other moveable materials in its structure besides his own personal friends. $\mathrm{L}^{\mathrm{d}}$ Harrowby has for several years avowed a wish to be relieved from the fatigue and the restraint of office, and now declares that he was only induced to retain it, because he thought it dishonourable to desert Canning when in difficulty. $L^{d}$ Goderich is in the same mind, and had carried his wish farther than mere avowal ; for on the death of his daughter last autumn he asked $L^{d}$ Liverpool to let him retire, and only remained at the earnest desire of $\mathbf{L}^{\mathrm{d}} \mathrm{L}$., who told him that his departure would probably accelerate the downfal[1] of the Administration, $w^{\text {ch }}$ must happen whenever his own health shod disable him from keeping it together. It is a most curious fact that a Gov' w $^{\text {ch }}$ carried with it the confidence of the country to a greater degree than any $w^{\text {ch }}$ has existed for many years, should have been formed of such discordant materials as to have been kept together by one individual, and that individual a man who had fewer personal friends and less quality for conciliating men's affections than perhaps any Minister that ever lived. Besides $L^{d}$ Harrowby and $L^{d}$ Goderich there will be no difficulty in removing $L^{d}$ Bexley 


\section{I98 THE FORMATION OF CANNING'S MINISTRY}

and Wynn at any time. Canning dislikes them both. Ld B.'s removal wo ${ }^{d}$ not lose him a single vote in Parlt. Canning was engaged in an intrigue for his exclusion a few months ago, wch was opposed by $L^{d}$ Lpool, and now only retains him for reasons of convenience. Since Wynn has quarrelled with the D. of Buckingham, he is identified with no one except Sir Watkin [Wynn] and $\mathrm{D}^{\text {r }}$ Phillimore, and the office ${ }^{1}$ of the latter wo $0^{d}$ be a sop for some more valuable adherent.

(Hadspen House MSS.)

\section{The Marquess of Lansdowne to Sir James Graham.}

Berkeley Square. 29 April.-Many \& sincere thanks for your very kind \& explicit letter [No. 266]. Such proofs of kindness \& confidence have been my consolation during the last fortnight which has been to me a period of great $\&$ trying anxiety, \& will continue to be so whatever may be the result of the transactions in which we are engaged, \& in which my great object has been to give effectual support upon publick grounds to Canning's Govt, if possible without, if indispensable, with office. . . .

(Netherby MSS.)

\section{Earl Grey to the Marquess of Lansdowne.}

Berkeley Square. 29 April.-You do me only justice in believing that nobody can feel more deeply interested than I do in everything which may concern your comfort and honour, and what most affects my opinion as to the arrangements now depending, next to the public grounds on which it is formed, is the fear that they may not eventually be found to promote either. That nothing but the most honourable feelings of public duty can ever influence your conduct, I am perfectly satisfied, and deeply regret that our views of what that duty requires are so different. With respect to the proposed arrangements, not knowing what they are, I can give no opinion, nor indeed should I wish to give any. I will only therefore repeat what I said to you personally when we last met, that in you I have the greatest confidence, but that in the Administration generally, or in the principle and in the manner in which it is to be composed, I can have none; and this opinion I shall be under the necessity of declaring publicly whenever these matters

1 Judge of the Admiralty Court. 


\section{THE FORMATION OF CANNING'S MINISTRY 199}

come to be discussed. In the meantime do not imagine that I have it in view to take any measures of direct opposition. My position is now that of an individual, almost totally without political connections of any sort. I must stand therefore upon the principles on which I have acted throughout my public life, supporting such measures as are consistent with them, and opposing when the same circumstances require me to do so. Of you personally I could have no unwillingness to ask any favour, and it certainly was my first wish to have seen Howick brought forward by you, whether in or out of office, to fill an honourable station, for which I believe him to be well qualified, in the public service. But my opinions at present, which are also his, forbid my asking anything for him under circumstances which render it only too probable that he may soon be obliged to relinquish the seat which he now holds. ${ }^{1}$

There is only one other circumstance to which I wish to advert, though it perhaps is unnecessary, as being of little consequence either one way or the other. In the conversation which $I$ had with you, when I wished to resign into your hands the station which I had till that time held in the Whig Party, I declared my intention at no time to take the first office, and an unwillingness to take any, unless it was felt to be necessary to give strength to an Administration formed on right principles; but not a positive determination not to take office in any case. The difference is immaterial, but for the sake of accuracy I thought it right to state what I had said, or meant to say.

(Bowood MSS.)

\section{Charles Wynn to George Canning.}

Sunday [29 April].-I yesterday met at dinner Spring Rice, who assured me that the charge of malignancy against Lord Duncannon was quite groundless and that both he and his brother have been uniformly anxious and active to promote the junction. He might therefore be advantageously taken into council upon such occasions as that of yesterday.

Upon the subject of the Government of India, I should think much must depend on a preliminary question. Would you be

${ }^{1}$ Lord Howick, Earl Grey's son, was M.P. for Winchelsea, being returned by the influence of Lord Darlington, who supported the Coalition. Howick did not resign his seat. 


\section{THE FORMATION OF CANNING'S MINISTRY}

allowed to charge that appointment as an equivalent for the proposed seat of one Whig Commoner in the Cabinet ? If this were not to be the case, you would, I think, gain nothing by the deportation of Tierney, especially if you were to be saddled with Lord John Russell, who would probably be proposed in his room if Lord Althorp continued to decline office, and who would be much more objectionable. If considerations of present convenience were set aside, there can, I apprehend, be no doubt that the nomination of Lord Grey would be more honourable to your Administration and more likely to prove advantageous to the public. That of Lord W. Bentinck would perhaps be equally popular; but I am not sure that it would be as beneficial.

(Harewood MSS.)

\section{The Duke of Wellington to the Marquess of Londonderry.}

London. 29 April.-I return Lord Ellenborough's note, and I must say that I don't think we are sufficiently informed to be able to form a judgment of the course of proceeding to adopt in the House of Lords. They said last night that neither Tierney, Calcraft nor Sir James Mackintosh were to be appointed for the present. Upon the whole I should say that the measure would be at present unwise, and might have a bad effect. There never was such a miserable piece of juggling as that said to be in contemplation. But it would not be wise to attack it till it will be quite certain that it is in the course of being adopted.

(Londonderry MSS.)

\section{4: George Canning to Sir William Knighton.}

F.O. 29 April. Private \& confidential.-I have heard with the greatest dismay that it was publickly stated yesterday afternoon at the Office of Woods \& [Forests] that $\mathrm{M}^{\mathrm{r}}$ Calcraft was not to be, $\&$ that $M^{r}$ Freemantle was to be ${ }^{\text {st }}$ Commissioner. If I were to tell you in what embarrassment this premature report involves me, you would I am sure, see how much such things affect my character \& efficiency. I certainly should never have thought of naming $M^{r}$ C. to that office unless I had believed the nomination agreeablenor have I named him to himself. Nor will I if I can by possibility find any means of commutation. But as to $\mathrm{Mr}^{\mathrm{r}}$ Freemantle, it is really impossible to appoint him to such an office without offending 


\section{THE FORMATION OF CANNING'S MINISTRY 2OI}

every man holding or hoping for Privy Councillor's office. He had never taken, nor can take, any effective part in debate. The very fact of his being so nearly connected with the Court would invite attention to his department. ${ }^{1}$ That I wish Freemantle well is sufficiently plain from my having voluntarily offered yesterday (before I saw you) to bring him into Parlt as soon as I could find an opportunity. But to put him so forward as the proposed appointment must put him, would, I am quite sure, be invidious on his own account, \& most inconvenient to the Governt. Luckily the filling-up of the office does not press for $a$ day, and I must have time to arrange so difficult a matter as it is now become.

(Ann Arbor MSS.)

\section{George Canning to Lord Plunket.}

30 April.-It is most vexatious to me to find that your Lordship's. name was omitted in the list of persons summoned to be sworn of the Council, and kiss hands today. It was no personal omissionI am sure, for Sir John Leach was also omitted, and so was the Duke of Montrose. There will be another Council in a few days, I hope, when this omission shall be rectified.

(Harewood MSS.)

276. Sir James Macdonald to the Marquess of Lansdowne.

Duke Street. 30 April.- . . . I rejoice, I own, in the outward demonstration that will be afforded to the public of the possibility of your feeling yourself able ultimately to comply with the public wish, by the acceptance of office on the part of Abercrombie and (should you so think fit to arrange it) of myself. That which I am sure you will not require of us is to continue to hold them should you yourself not, accept. I have no hesitation in saying that if $I$ am to be in office I had rather be at the India Board than anywhere, because it would induce me to devote myself to the thorough understanding of the great subjects that in the course of a few years must come under discussion with reference to that Empire, and to which I might look to obtain some little credit, and compensate for some years of idleness. I am most anxious however that you should consider me in no other shape than as

1 Fremantle was Treasurer of the Household. 


\section{THE FORMATION OF CANNING'S MINISTRY}

it may suit your own views-and if my standing out of the way can in any possible mode be made to assist Mackintosh, you will not hesitate I trust to put me quite out of the question. The point of parliamentary attendance struck those to whom it was mentioned as so insuperable a difficulty that they would not allow me to write to mention the matter (with your sanction) to Mackintosh himself, and Abercromby seemed to make so great a point of the arrangement as to myself continuing, that I could not venture to press it further till he was secured. Copley, from his language to me seemed to be anxious to do something himself for Mackintosh out of Parliament, but there again another difficulty, I fear, occurs. On the whole you will do what you may think best. . . .

(Bowood MSS.)

\section{J. Loch to the Earl of Carlisle.}

Bloomsbury Square. [30 April.]-I trust that your Lordship will pardon me for addressing you on a.matter of public importance in which you have no immediate interest, but which is materially connected with the prosperity and happiness of that part of the Kingdom with which I am connected by birth. I allude to a report which has got into circulation, that the new Administration intend to revive that anomalous, and, I will add, that grievous and mischievous situation, " a Minister for Scotland "-that fruitful source of misgovernment, oppression, and jobbing. Of late years Lord Liverpool in his department, and still more $M^{\mathbf{r}}$ Peel in his, have done much to remove this grievance, nominating to the Scotch appointments (as ought to be the case) on the same footing as any English County-to the incalculable advantage of, and with the decided approbation of the people of that country. The late changes in the Administration have been hailed by every one, not immediately connected with Lord Melville or Lord Lauderdale as particularly propitious, as affording the most admirable opportunity of completing this good by bringing the people of that portion of the Kingdom into direct contact with the Government here, and thus enabling the latter to understand the actual circumstances and position of the country and to appreciate its wants and to attend to its just claims. If however such a situation is to be revived, Scotland will suffer in its interests most immediately and seriously by the change, and the people of that country will 


\section{THE FORMATION OF CANNING'S MINISTRY 203}

have to regret the loss of Mr Peel's liberal system of administration, by being thus cast back into all the grievance of a deputed and irresponsible government, in place of having its affairs considered by the candid and impartial mind of an English gentleman. I consider that I have the best means of forming a correct judgment on this subject. For by birth a Scotchman, my 27 years residence here, have made my connexions and pursuits now mostly of this country, while my annual professional visits to all parts of that country, leading me equally into all classes of society and of politics, give me opportunities of observing and marking the feelings of the people, better than others more immediately connected with the country and its politics - enabling me also to mark and ascertain the evils which would accrue to that country, if administered otherwise than directly through the English official departments, avoiding most especially the extremes of both Edinburgh parties. ... ${ }^{1}$

(Harewood MSS.)

\section{Lord Binning to George Canning.}

Monday. 30 April.-I conclude that I have little or no chance of seeing you today. I am sure from the mode of your communication to me last night that you are angry with me. I cannot rest without endeavouring to convince you that I do not merit censure, and therefore I sit down to make this appear as well and as shortly as I can upon paper.

The extract you sent is so invidiously worded that it came I feel sure from no friend of mine, but however that may be it is certainly true that to a Scotch solicitor, whom I have long knownwho is a man in manners and acquirements much above his calling, and whom I did not seek for the purpose, but had called upon on private business of my own-I did make the statement referred to. I did not volunteer it. I made it in answer to his questions to me about my name having appeared in the papers as a Lord of the Treasury. I hesitated about making it, but not conceiving that there could possibly be any motive for secresy-never have received any hint to that effect-inferring indeed from all that had passed that it was better it should be known-I ended by stating the fact to him. The quiet and moderate Scotchman I take to be Kennedy, who saw this solicitor, I know, after I left him. Quiet

1 The letter was forwarded to Canning. 


\section{THE FORMATION OF CANNING'S MINISTRY}

he is in his natural temper, and about as moderate I should conceive as the Edinburgh Review. I did not think of keeping this matter a secret. First, because I did not see how it was possible to keep it a secret above a day or two. Secondly, because it was to have been the explanation of my seat at the Treasury had not that been given up. Thirdly, because I was to communicate it to my friends in the north, and that Clerk was to state it there, which he has by this time done. Fourthly, because I knew great anxiety did and must prevail among those who were likely to be your best supporters in Scotland and here ; great anxiety as to the hands into which that business would fall, and that I did believe and do believe that its being known to have been devolved by you upon a long tried friend of your own would afford a satisfactory solution to that anxiety and doubt. To tell you the truth $I$ thought the chief value of the appointment consisted in its being speedily known to all three persons, indicating as it does your first feelings with respect to Scotland, and pledging you literally to nothing for the future. It cannot surprize any Whig among them, let them say what they will. That they would have liked an Under Secretary of Lord Lansdowne's better, I doubt not; that they have any personal indisposition to me I do not believe either with regard to Kennedy or any one of them. That they and all the Scotch members would prefer another system I am quite certain, and have said so from the beginning ; and if this denouncement of me to you means anything, it is a declaration against the system ; that if not made on one day would equally have been made on the next, and which is better, much better made early, and before things are in train-and when the matter can be turned anyhow-than made late when things have gone so far that change would be retreat. . . .

I will conclude with desiring you to dispose of me absolutely. I have no wish for the thing if it is not to be a clear and decided advantage to you. It could in such case only produce misery to me. If you were to contemplate a change of the system, the worst thing that could happen would be to do it in a hurry. There is all the time between this and the next Session to arrange it. Nothing that I have said or that you have done is inconsistent with your giving the present state of things a temporary character both as to man and system, if you see fit to do so. I repeat that if this has been the means of causing you a moment's vexation, it distresses me infinitely. (Harewood MSS.) 


\section{THE FORMATION OF CANNING'S MINISTRY 205}

Ibid. [c. 30 April].-I have brought down the enclosed with me. Stapylton [sic] has given me the anonymous letter to Lord Carlisle. I see nothing in this to make me withdraw my letter. Although the writer is under the delusion of imagining that Peel acted entirely for himself, and forgets that Lord Melville was the ostensible adviser for Scotland, yet I am well aware that to a greater or lesser degree the general feelings expressed by this person are entertained by many, many of my countrymen. It is nonsense to imagine that a Minister of this country can manage Scotland without consulting some one-that some one will infallibly be the person to whom people will address themselves. The question is what shall be the character of that individual. For Heaven's sake do that you think fittest to be done. This man uses the word "Minister for Scotland." I never used any such term. He attributes the late liberality in appointments to Peel and Liverpool only. This I believe to be most unjust to poor Melville. I know it to be unjust to Solicitor General Hope. (Harewood MSS.)

\section{Lord Binning's Memorandum, for Canning.}

[Undated.] $Q^{\text {n }}$. The propriety of communicating with Lord Montagu as representing the Buccleuch family-through Douglas. ${ }^{1}$ Wallace and Lady Melville are very sensible of your kind behaviour. The latter is full of it and has charged me to say much. I owe it to $\mathrm{Wm}^{\mathrm{m}}$ Dundas to let you know that far from applauding Melville's course he deeply and bitterly deplores it.

(Harewood MSS.)

\section{George Tierney, jun. to Sir Charles Bagot.}

S. Row. I May.- . . . Do you know that the D. of Rutland has repented him of his opposition intentions, and sent in his adhesion to the new Govt ? I believe this is fact. On the other hand that huge hill of flesh the D. of Buckingham, after first consulting with $L^{\mathbf{d}}$ Lauderdale as to the means of making an effectual opposition to Mr. C., then two days later notifying his determination to support him, now shifts round again, upon being refused India, and vows eternal hatred: in about a fortnight,

1 W. R. K. Douglas, a Junior Lord of the Admiralty, was the brother of the fifth Marquess of Queensberry, who had married a daughter of the third Duke of Buccleuch. 
however, I expect he will come back again if he finds the Govt strong.

The King said the other day to the D. of Devonshire, when he kissed hands, "God damn their souls, I never wish to see one of their faces again except the D. of Dorset." It must be owned he has a wonderful command of language.

... The new Govt appear to have got all the papers on their side except the Morning Herald. ${ }^{1}$ Brougham writes the Times articles himself, and makes frequent mention as you will have observed, of his own disinterestedness, \&c. \&c. He is a funny fellow. ...

(Bagot MSS.)

\section{George Canning to John Calcraft.}

F.O. I May.-You were not to suppose that because I have not asked to see you, you are out of my mind. I assure you it is not so. Difficulties have arisen which it will require perhaps some days to remove, and which I will then explain to you fully.

(Harewood MSS.)

\section{John Calcraft to George Canning.}

I May.-I have the most perfect confidence in you, and shall wait patiently with some anxiety until the time comes when I may know from what quarter, or how the difficulties have arisen. (Harewood MSS.)

\section{The Countess Cowper to Frederick Lamb.}

London. I May. - . . During this moment of bustle and turmoil there was nothing to be done, but the inns and outs were all sworn on and off yesterday. ... $\mathrm{W}^{\mathrm{m}}$ is pleased with his. appointment and feels I think comfortable to be fixed in his politicks after having been so long no how. The Tories are furious. at seeing their hopes of return cut off by the accession of the Whigs, and there is so much confusion and splitting amongst families and parties that it is quite a service of danger to talk politicks at all, and yet it is impossible to talk of anything else. Ld Grey and few discontented Whigs still look upon $\mathrm{L}^{\mathrm{d}} \mathrm{L}$ [ansdowne] as disgraced

1 To which should be added the Morning Post, the Standard, the Watchman, the St. James's Chronicle and John Bull. 


\section{THE FORMATION OF CANNING'S MINISTRY}

and think that if the Whigs had refused any negotiation and had stood aloof, they would have had everything in a short time on their own terms, but this is all visionary, they would have lost their opportunity and have caused the return of the Tories-who are only now so violent because they see themselves lost. It is very agreeable for us to see this complete turn of affairs and a short time ago so very unexpected. This quibble of provisional Govern ${ }^{t}$ and keeping places and stop gaps is all a great piece of nonsense, but still I think it will make no difference as both parties are sincere ( $\mathrm{I}$ believe)-mais cela prête au ridicule and is absurd and makes explanations necessary, and is moreover very unpopular, for not one person have I heard really approve of it, but still I think all will be right in the end. I suppose $L^{d} \mathbf{L}$. had many things to swallow which he did not like-and I suppose he fancies this to a certain degree saves him-in fact he does not at all like the concern, and has no nerves to meet the charges of inconsistency, but he has sacrificed himself to the very strong feelings of his party and to their interest, - - otherwise his own wish and inclination was certainly to refuse. If $L^{d} \mathrm{~L}$. had decidedly refused, $\mathrm{W}^{\mathrm{m}}$ would have had the Home [Secretaryship] which I should much have liked, but of course he could not have been asked to have taken it ad interim. $\mathrm{L}^{\mathrm{d}} \mathrm{L}$. still stands for the Home after the Session, but I am always in hopes that he will come in for the $I^{\text {st }}$ Lord of the Treasury, and then $\mathrm{W}^{\mathrm{m}}$ have the Home, and I feel little doubt this would be the case, if he is not by that time in the $\mathrm{H}$. of $L^{d s}$ but that would be a misfortune for him and diminish his importance. C[annin]g speaks most highly of him-told $M^{\text {de }}$ L[ieven] he looked upon him not as one, but as the cleverest person going. I am afraid he will find Ireland a hornets' nest, but he seems very stout-hearted and well satisfied. I have a bet with Agar Ellis that the Catholic question is carried before two years and I don't feel afraid of losing him, altho Henry says he is the stoutest Protestant in England notwithstanding the II [? 2] in the Cabinet. ... I I am rather sorry for the Bathursts as I hear they are poor and can ill afford to be out of place-they talk of going to travel, and to join $L^{y}$ Emily if $\mathrm{Mr}^{\mathrm{r}}$ Bathurst is strong enough. Fitzroy Somerset [?] I am also quite unhappy about, but I hope the Duke of B[eaufort] (?) will do something for them now, and I have no doubt he will get provided for somehow, either by the Duke's return or in the Army. The military affairs are all to pass thro the Secretary at War as they did between the death of 


\section{THE FORMATION OF CANNING'S MINISTRY}

Duke Y[ork] and the Duke W[ellingto]n's appointment-and Sir $\mathbf{H}^{\mathrm{t}}$ Taylor is made Deputy Secy at War. Henry wished much to have avoided this corvee and to have had everything his own way,-but he was bullied about it. George is to come to town to-day-I have not seen him since all these affairs but I believe he is reasonable. Duke $\mathrm{D}$ [evonshire] is in the $7^{\text {th }}$ Heaven with his Chamberlainship- $L^{d}$ Morley is to have the Mint (ad interim) like Sturges Bourne, Lord Dudley, and the Duke of Portland, and then afterwards he is to march off upon the Post Office. I wish it had not all such a puzzling appearance. The Morning Chronicle says its like people going to keep places for the first act of a play. Everybody is on tiptoe to-day for the meeting of the House of Commons, and the $\mathrm{H}$. of Lords to-morrow-there are expectations of Sir [H.] Harding[e] stating Duke W[ellingto]n's case, and of his speaking himself to-morrow but I hope this may not be so. I am so afraid of anything widening the breach. I know it is not the Duke's intention to do so, but in speaking people get angry and forget themselves. They say yesterday the Court was very curious, all the ins and outs shown by mistake into one room. 2 Chancellors, 2 Chamberlains all in pairs, and the $\mathrm{K}$. in such a state of perspiration that it seemed as if he would quite melt away. The two last days summer is quite come upon us-to account a little for this heat, but I suppose the thoughts of meeting all these people was not very cooling and comfortable. ...

(Broadlands MSS.)

\section{The Duke of Rutland to Mrs. Arbuthnot.}

The Woodhouse. 2 May.- . . Y You write me most excellent sense in advising patience \& quietness under the goading circumstances of publick affairs in which we are placed. I am convinced that it is the only line which good policy et l'amour du trône et de la patrie, would point out. If anything hasty \& intemperate were done, which might have the effect of irritating the King, we should perhaps render perpetual the schism between him \& the Tories, and throw him for better for worse into the arms of his new friends. I have several times been on the point of [writing to] the Duke of W[ellington], but I know not whether it would be agreeable to him to hear from me, nor indeed how I could make it worth his while to waste his time in reading a letter from me. And as I shall ere long be in London I hope he will allow me the 
pleasure of an early interview with him after my arrival. My political creed is contained in half a dozen words- $\mathrm{I}$ had rather see him First Minister of the country than any one in it. But the King is my first object, any individual or set of men the second object only, after I am satisfied respecting the principles of an Administration, which must ever be my paramount consideration. The primary question with me therefore is, can I or shall I be satisfied with the principles of the present Government. I am firmly convinced that they will at first sail under false colours, \& that their real principles \& intentions will only be declared \& their true colours hoisted at the main peak when the opportunity for shewing them is more opportune. In the meanwhile if the Opposition support them it will in my opinion be impossible for those who have been diametrically opposed to the Whigs, to unite with them, unless they can dispose of former tenets \& principles, as a cow chews her cud, and come over to our sentiments \& feelings on various important subjects. And what a set of fellows they must be if they do this!! The explanations of the first week in Parliament will probably give us a clue to the line which it will be meet to take, $\&$ till then I am sure that any decision would be premature and absurd. My two brothers ${ }^{1}$ are enthusiastick respecting the gentleman whom they know by the nickname of " the Beau," I imagine some old Peninsular familiar appellation. They say "Whatever happens, we'll stick by 'the Beau." . . .

(Arbuthnot MSS.)

\section{J. W. Croker to George Canning.}

Admiralty. 2 May.-I presume that you are still of opinion that H.R.H. the Duke of Clarence should have the Cabinet key which Lord Melville now has. H.R.H. will not, else, be able to open any boxes or hold any communication with the members of the Government or even with $m e$, who have the Cabinet key. . . . [Endorsed, "Yes, G.C."] (Croker MSS.)

286. Alexander Baring to the Marquess of Lansdowne.

Piccadilly. 2 May.-[Asking for a peerage]. . . . My personal position in the world is so well known to you that I hardly need

${ }^{1}$ Lord Charles Henry Somerset Manners and Lord Robert William Manners. 


\section{IO THE FORMATION OF CANNING'S MINISTRY}

explain it. My success in the world in my own particular pursuit is almost without a parallel, and I believe I may with truth add, what is not always attendant on the accumulation of a large fortune, that my character has been uniformly and successfully upheld. For some years past I have been withdrawn from active occupation, and with a clear income of between fifty and sixty thousand a year, of which the larger portion is in land, attended with every desirable circumstance of political influence, and with my eldest son ${ }^{1}$ with character and habits which encourage me in indulging the vision of founding, as it is called, a family, the only thing that remains to me to wish for is the finishing my career by a seat in the House of Peers. . . .

(Bowood MSS.)

\section{The Duke of Wellington to Lord Londonderry.}

London. 3 May.-If you had not mentioned to me what passed yesterday I should not have mentioned the subject to you. You may rely upon it that no public assembly will listen to any personal question having a remote origin, in which no immediate public interest is involved. Your poor brother had as far back as I8I2 consented to act with Mr Canning in Cabinet. He did so act with him from I8I6 to I82I [sic], and he made another effort previous to the calamity of his death to obtain the King's consent to $\mathrm{M}^{\mathrm{r}}$ Canning's reintroduction into the Cabinet; and the public will not now hear of the revival of that topic for their discussions. Neither will a public assembly bear to be addressed upon rumours. I assure you that several of your best friends heard you with pain, and spoke to me on the subject. But I would not have written a line upon it if you had not written to me. I am sure it is best that the subject should here be dropped. ${ }^{2}$

(Londonderry MSS.)

1 William Bingham Baring, second Baron Ashburton. Baring received a peerage in 1835 .

2 See Londonderry's speech in the House of Lords, 2 May (Parl. Deb., N.S., xvii. 485). The Duke repeated his advice on the I 7 th : "I earnesly recommend you to publish nothing excepting in general terms as stated the other day. If you do publish, every word in all the letters will be pulled to pieces, and in this sort of contest a gentleman always suffers" (Londonderry MSS.). 


\section{Henry Hobhouse's Diary.}

Saturday. 5 May.-On Monday the King held a Court, when the $L^{d}$ Chancellor and the 3 Secr $^{8}$ of State delivd up their Seals, $\mathrm{w}^{\mathrm{ch}}$ were delivered by the King to the successors, who were sworn in, as were other great officers appointed by patent. At first it was not intended that $L^{d}$ Anglesey should take a seat in the Cabinet until after the passing of the Corn Bill, wch he has opposed. ${ }^{1}$ But he has since determined not to wait for that event.... On Tuesday in the House of Commons, and on Wedny in the Ho. of Lords the ex-Ministers took occasion to explain the circumst ${ }^{\mathrm{s}}$ and the motives of their resignations. The King has taken great offence at some expressions used by $L^{d}$ Mansfield in the course of his speech made on the latter of these occasions, which appeared to the King to impute to him a want of sincerity in the sentiments expressed by him to the $\mathrm{Ab}^{p}$ of Canterbury and $\mathrm{B}^{p}$ of London at their audience on Easter eve respecting the Catholic question. ${ }^{2}$ He sent yesterday for the $A b^{p}$, repeated to him that his opinions on that question agt the $R$. Catholics were quite as strong as his father's ; and has written to the $\mathrm{Ab}^{\mathrm{p}}$ a spirited letter, expressing this opinion, stating that if he were in a different station he shod think such expressions ought to have called for a very different proceeding, and commanding the $\mathrm{Ab}^{p}$ to read this letter to $\mathrm{L}^{d} \mathrm{M}$. (Hadspen House MSS.)

\section{The Duke of Rutland to Mrs. Arbuthnot.}

Stanton Woodhouse. 5 May.- . . . Indeed I should have rejoiced to have heard the Duke's exposé in the Lords \& Peel's speech in the Commons. Each I hear from all quarters was most triumphant-and it seems to have been done with the greatest consideration for the royal feelings. Vilified \& abused as they have been, \& particularly the Duke, I am almost surprised at the cautious guard which was placed upon the temper. The only part of the Duke's speech with which I find the least fault is that in which he throws such utter discouragement on the idea of his being ever the Prime Minister of the country; whereas he is of all others the man whom I, \& I truly believe, very many others would most like to see in that situation. Your husband gave me

1 This is confirmed by Stapleton.

2 See Parl. Deb., N.S., xvii. $47^{\circ}$. 


\section{I2 THE FORMATION OF CANNING'S MINISTRY}

a supplementary line after you had written your last note, \& I have answered him that he need not fear my doing anything which can pledge me in the most distant manner to a particular line of conduct before $I$ arrive in London. Before that time surely Mr Canning must feel the degradation of soliciting \& receiving aid from his new allies, the Radicals, \& will have hurled them overboard. Nous verrons au moins. . . .

(Arbuthnot MSS.)

\section{The Duke of Bedford to Lord Holland.}

5 May.- . . . You cannot understand why I think this junction removes the consummation of the Catholick wishes to an indefinite distance, and I will explain as clearly and as shortly as I can why I think so. We have long complained (at least I have) of a divided Cabinet, which in fact virtually implied that the Cath. question never could be carried under such a system. After all we have seen for the last 20 years I felt firmly convinced that the Catholick claims never would be acceded to, but through fear. The time was fast approaching when that fear was likely to operate on the royal mind-the Catholicks of Ireland were daily assuming a more imposing and formidable attitude, and I began to hope that there was some chance of the question being at length carried. We have now made ourselves parties to the same juggle of which we have been so long complaining. Dust is to be thrown into the eyes of the unfortunate Catholicks, and the same opiate which has rendered them patient under their unmerited sufferings for so many years, and lulled them to rest by false hopes, from Canning and Co., is now to be administered by the hand of Lord Lansdowne $\&$ the Whigs of England!

You say that the Irish proprietors and the Catholicks themselves are decidedly in favour of this junction. I readily believe it. An Irishman by his nature is generous, confiding and unsuspecting; and I have no doubt that the well-intentioned among them will readily give admission in their minds to the belief of their fondest hopes being realized, when they are told that their real friends are now coming into office and that Catholick emancipation must be the inevitable result. With regard to the Catholicks themselves, the leaders of that body, the agitators and separatists, Messrs. O'Connell, Sheil, \&c., have no wish to see emancipation carried (it is entirely hostile to their views) and they have sagacity enough 


\section{THE FORMATION OF CANNING'S MINISTRY}

to discover that this junction removes the event to a still greater distance ; they therefore naturally approve it. But after all, what are we to get by it ? What is the country to get by it ? Nothing can be more truly ridiculous than the bugbear of the old ultra Tories coming in again, and nothing can force them back but the ridicule \& unpopularity of this Coalition when the publick begins to see through it. The Whigs stood upon high ground, \& Lansdowne ought never to have suffered him[self] to descend from that high ground, assailed as he might have been by craft on the one hand, \& clamour on the other. Canning could not have stood unassisted by the Whigs. The ultras were confessedly unable to form an Administration by themselves, and they would clearly not have again joined Canning. The Whigs might then have made their own terms. They might without dishonour have received the assistance of Canning \& his friends, and Catholic emancipation would have been the natural and inevitable result. The opportunity is lost, the Whigs degraded, and the great \& vital question virtually abandoned. Canning has actually done so in his speech and has again reverted to the invidious declaration in his speech on Burdett's motion, that the country is against the measure. But this I maintain to be false. They will be so now perhaps, as their passions \& their prejudices will be stirred up. Peel in his speech certainly says that C[atholic] e[mancipation] is nearer its accomplishment by the appointment of the Coalition Administration. It is in some respects a manly and straightforward statement, but it is on the other hand an able and an artful one, and what I like best is, it is that it clenches the nail [sic], and leaves Canning without a retreat. He must bring the question forward himself in the next session of Parlt, backed by all the influence of Govt, or he must consent to be branded as the veriest knave that God ever framed. I may be wrong in my conjectures about Canning, and I hope I am; for if he betrays the King instead of the poor Whigs, I believe I could so far stretch my morality as to pardon the treachery in favour of the benefit it will confer.

When we descend to the minor parts of the transaction, they form a very ludicrous spectacle. How ridiculous are these provisional Ministers, and what is the object of this hocus-pocus work \& pantomimic machinery? For tho' Lansdowne says he and Canning have thought it for the best, he does not condescend to tell us why. The Duke of Portland Privy Seal-God help him ! Sturges Bourne, who I remember a briefless barrister, brought 


\section{I4 THE FORMATION OF CANNING'S MINISTRY}

forward by Mr Pitt, with scarce any pretensions to a subordinate office, Secretary of State! And to crown all, $L^{d}$ Dudley Foreign Secretary!. We are told that these appointments are only temporary. You may appoint one of your stable boys to be your cook, and when your friends come to dinner with you, tell them the appointment is only provisional, but I believe they would be as little satisfied with it, as the Foreign Courts and Ministers will be with the provisional appointment of $L^{d}$ Dudley, with his unfitness for business and various wanderings and distractions. Really the whole thing looks like one of Canning's jokes. I repeat, it would be ludicrous in the extreme, were it not for the melancholy consequences that must ensue, $\&$ the pain it gives me to see such a man as Lansdowne a party to such transactions.

"Who would not laugh, if such a man there be, who would not.weep, if Atticus were he?"

What pleases me best in all these ridiculous transactions, is to see old Citizen Tierney become a Cabinet Minister after 40 years hard labour to attain that eminence. I am pleased at it, because I like him \& admire him personally, very sincerely ; because I think it will cheer his old age, and he will not be troubled with any "compunctious visitings." ...

(Holland House MSS.)

\section{9r. George Canning to Earl Bathurst.}

Downing Street. 6 May. Private-Having requested you to keep secret at the time, the proposal which I took the liberty to make to you, after your resignation, and the reason for which I requested that secrecy being long gone by, I think it right to release you from that obligation. I do this the rather, because, as I find that one of the charges to be brought forward against me in the House of Commons is that I had made either no efforts, or insufficient ones, for retaining or regaining any of my former colleagues, I may be obliged, in my own defence, to quote my application to you, and I could not properly do so without previously removing the restriction under which that application was made. I have no intention nor wish to enter upon such topicks : but after what has passed in both Houses of Parliament, there is no saying how far one may be driven, or where one can stop in disclosures. Believe me, however, that whatever I may be driven 
to in that respect, I shall not speak of you otherwise than as I feel-that is with that real regard with which $I$ am, dear $L^{d}$ Bathurst, very sincerely yours.

$$
\text { (Add. MS. 40394, ff. I03-4.) }
$$

\section{Earl Bathurst to George Canning.}

Stanhope St. 6 May. (Copy.)-As the knowledge of one refusal will on occasions like that which has recently occurred encourage others, I should have thought it unfair by you even if you had not requested secrecy, to have disclosed your offer and my refusal as long as you were under difficulties in filling the situation of Home Secretary, but after Mr Sturges Bourne's acceptance avowedly for your accommodation, every reason for secresy is as you observe long gone by. I have therefore only to assure you that I am very sensible of the kind manner in which you have communicated your intentions of mentioning the circumstance eventually in the House of Commons.

$$
\text { (Add. MS. 40394, f. I06.) }
$$

\section{George Canning to Lord Binning.}

7 May.-I have learnt from more than one quarter yesterday and today, but today especially from positive authority that Sir G. Clerk goes about Edinburgh holding a most disparaging language of the Government, declaring that it cannot stand, and fixing even a short period for its downfall. Now this in a man who, having resigned, was permitted by me to return to office, and was even moved to a better place, I hold to be intolerable.

$$
\text { (Harewood MSS.) }
$$

\section{Earl Bathurst to Robert Peel.}

Stanhope Street. 7 May. Private.-I send you a letter which I have receiv'd this morning from $\mathrm{M}^{\mathrm{r}}$ Canning, and my answer. It seems by this that he means to make some grand discoveries. If he suspected that the coincidence shew'd the conspiracy, what made him make a confidential application to one of the conspirators ? (Add. MS. 40394, f. ror.) 


\section{I6 THE FORMATION OF CANNING'S MINISTRY}

295. Sir James Scarlett to the Marquess of Lansdowne.

New Street. Monday [? $7 \mathrm{May}^{1}$ ]. - The weather prevented my calling on you yesterday. Today I am on the wing for Peterborough. Therefore I take this method of adding my strong opinion and earnest wishes, to those which have doubtless been expressed by your other friends and which are the universal opinions and wishes of all but the ultra and factious Tories, that there should be some more distinct outward and visible sign of an union between you and the Government than the mere support by speaking and voting in Parliament. I need not trouble you with reasoning. It is enough to state as a fact of which I have the most positive assurances that the present state of affairs is full of doubt in the public mind and may be productive therefore of embarrassment and disaster to our best hopes. I have stated my opinions very freely in another quarter, and I have ventured to suggest what I conceive would be the best mezzo termino-if office is for the present out of the question-which is that you should at least take your seat in the Cabinet. I am confident that this would have a most beneficial effect and I hope it would set in motion (though in this I may be disappointed) the spirit which exists in the country but which cannot be called into efficient action by a provisional Government, not understood nor confided in by the people. I did not say that I should name this to you, but as I know of your intended interview I can have no objection to your stating it as my suggestion if you think it fit to do so. I am sure it will be well received and with the best disposition to accomplish it.

I have one word to say upon another subject. Would you have any objection to call at Gloucester House? I think it would be very gratifying to the Duke to receive that mark of attention from your Lordship at the present moment, which is one of great anxiety to him, on your account as well as on that of the public.

(Bowood MSS.)

\section{The Countess Cowper to Frederick Lamb.}

London. 8 May.-Things here are settling but the eagerness and the violence of parties you can hardly conceive, tho to be sure the reading of the debates may give you some idea of it, and of

$1 \mathrm{He}$ was re-elected for Peterborough after his appointment as Attorney General, on 9 May. 
the personality of course. With this going on every day foreign politicks and foreign arrangements have but a poor chance-even the disbanding of the National Guard was hardly noticed. You know when party spirit runs high in England how entirely it engrosses everybody. William however has spoken to his master, and will I hope write to you today-he said Mr C[anning] said he was quite puzzled what to do, that in the unsettled state of affairs it was a dangerous thing your coming away. $\mathrm{W}^{\mathrm{m}}$ urged the necessity of it, and the impossibility of your remaining there in the heats. Your next letter I wait for impatiently as you will then know the turn affairs have taken and perhaps be able to tell what you wish to do. This seems to me now pretty clearly what will happen.-That the Govern ${ }^{t}$ will be quite secure-Lord Grey and the few Whigs who stand off will come in by degrees and that in a few months Duke W. will somehow or other take back the command of the Army, it is decidedly his own wish whenever he can do so with any kind of credit. Henry does not wish it now, but he will in a few months when the novelty of a different arrangement is worn off, and $\mathrm{Mr}^{\mathrm{r}} \mathrm{C}$ [annin]g certainly looks to it as a necessary plan, for tho it is all managed very well at present by the Secretary at War, and by appointing Taylor his deputy but it is too much work for one man to superintend, and certainly too much power, since in fact $L^{d} L$ [?] gives away all the things that were before with the Commander-in-Chief, however nobody objects to the arrangement at present as all sides look upon it as one of the provisional arrangements to keep the place for the Duke. A great many Tories are come round, many hang off to see the first division, but there will certainly be a large opposition party in the Lords-some people who hate the Whigs, others personally Mr Canning, but they have no talent on their side and can therefore do nothing but be troublesome, and for myself I am glad they are so violent because it makes the breach wider between them and the King. He was in particular furious at $L^{d}$ Mansfield's speech and said if he had not been King he would have called him out. ... He was very much pleased with Burdett's and altogether with the whole tone the Whigs have taken, and Francis who came to pay me a visit the other day says the $\mathrm{K}$. is certainly delighted in his heart at the thoughts of getting back to his early friends, such being the case, one does not know what is to overturn the Governt. The Whigs and $\mathrm{C}[\mathrm{annin}] \mathrm{g}$ are both sincere in their union and it is now the interest of the latter to be so since he has 


\section{I8 THE FORMATION OF CANNING'S MINISTRY}

irrecoverably quarrelled with the other side. . . . The violence of the Tories upon the junction of the Whigs and C[annin]g shows how completely they look upon it as their death blow, and Peele who before this was standing independent Cap $^{\mathrm{n}}$ grand [?], immediately declared in opposition from despair, it is a curious thing to look at the Ministerial and $\mathrm{Oppo}^{\mathrm{n}}$ benches, so differently filled from what we have been accustomed to-and all the talent on the Ministerial side-but the policy is to keep all their speakers back and to say as little as they can help, not to give any hold to the other side to answer. Brougham and Burdett's speeches have been excellent. The former is quite an altered man, so prudent, so good humoured, in such tearing spirits-he feels that he stands so high from rejecting all favour or places, and yet by the state of things he has his advantages, Scarlett's promotion leaves him 2,000 a year on the Circuit and he gets revenge upon $L^{d}$ Eldon and Lonsdale, however the latter is trimming and $L^{\mathrm{d}}$ Lowther sat on the Ministerial benches the other night. The Bathursts I am sorry for as they say he is very poor. The Tories have so long been in office that taking away their places is counted by them like taking away their private property. Aberdeen is very bitter, but this they say is disappointment that C[annin]g did not offer him anything or try and make a Govern ${ }^{t}$ without the Whigs-an interested Scotchman. Henry's feeling is certainly still very strong about the Catholics but they hope time will move him, and people think this was one of the reasons for delay in $\mathrm{L}^{d} \mathrm{~L}$ [ansdowne] taking office that they hope the $\mathrm{K}$. may by that time be brought to allow of more Catholics in the Governt. Ld C [owper] is in great spirits and delighted at the state of things and very decided in his opinion for the present Govern ${ }^{t}$ yet $L^{d}$ Grey hates it, and Duke of $\mathrm{B}$ [edfor]d hangs back. The best fun they say is to see $L^{d}$ King sitting amongst the Bishops-(Church and King) his John ${ }^{1}$ was very good about the rubbish-they say on the other side that the mixture of individuals on the Ministerial benches would never hang together if it was not for the Roman cement. . . . Brother $\mathrm{W}^{\mathrm{m}}$ looks more happy and comfortable than I have ever seen himand George is also much pleased, and sits with great satisfaction on the Treas ${ }^{y}$ bench.

(Broadlands MSS.)

${ }^{1}$ Possibly his young son, Peter John Locke King (b. I8II). 


\section{The Duke of Devonshire to George Canning.}

9 May.-In consequence of our conversation this afternoon and of my anxious desire for the conclusion of the subject of it, I have seen Lord Lansdowne and $M^{r}$ Tierney, and I can inform you that in the event of the latter accepting office now, it is considered essential that he should take his seat in the Cabinet at the same time as Lord Lansdowne, who for the sake of the completion of the arrangement in the House of Commons, is ready to carry into effect the settlement which it had been before proposed to defer, excepting as to any postponement that may be deemed necessary from delicacy to the Duke of Portland, of Lord Carlisle's entrance into office, as well as of his own. With regard to the declaration to which I alluded when I saw you, I feel sure that you cannot object to a statement from my friends that whilst for the purpose of promoting the common interest, and adding to the strength of the Government, they can consent to take office now, instead of at a future time as was contemplated, they feel the necessity of reserving to themselves the right to retire should circumstances occur connected with the construction of the Irish Government which would make them feel it contrary to their opinions and views of what is due to the tranquillity of Ireland to remain in office. I hope you will feel that this declaration on their parts is intended solely to prevent the possibility of any future misconception in certain contingencies which I trust may never arise, and with the most anxious desire for a final result calculated to satisfy the country and to hold united those whom I have so much pleasure in seeing acting with you, I have the honour to be [etc.]

(Bowood MSS.)

\section{The Duke of Wellington to the Marquess of Londonderry.}

London. 9 May.-I return the Duke of Buckingham's letter of the $6^{\text {th }}$ which I had mislaid by accident. Nothing could be more ridiculous than to think of principles of forming a Govt almost at the moment at which we have been obliged to quit office in consequence of our not thinking $\mathrm{Mr}^{\mathrm{r}}$ Canning's Gov ${ }^{t}$ of a nature to satisfy the King or the public. I have not spoken to Peel upon the subject, but at all events $I$ could not enter into such matters.

(Londonderry MSS.) 
299. The Marquess of Lansdowne to George Canning.

Berkeley Square. Thursday morning [Io May].-As it was the Duke of Devonshire's intention to send you early this morning the substance of a conversation which by his desire he had with Mr Tierney and me late last night, I am only desirous of saying that I trust you will not infer from it that I have myself the slightest objection to the arrangement continuing suspended agreeably to the opinion we had both formed with a view to existing difficulties, whatever wishes others may entertain on the subject, should you remain of the same opinion.

I take this opportunity of enclosing a letter from Sir J. Mackintosh to you, which he sent since I last had the pleasure of seeing you, open for my perusal ; but I ought to add that it appears to be the opinion of his friends, that if it is found practicable, a situation connected with the legal, would probably suit him better than that which he designates for himself in the diplomatic service. (Harewood and Bowood MSS.)

Ibid. Thursday evening.- I write after hearing a speech of Lord Grey's to which or rather to particular parts of which it is indispensable that I should refer on the first occasion (there will be one on Monday) in the House of Lords; and also that I should converse with you on the subject first, from the great delicacy of the points on which I must necessarily touch. . . I I need hardly say if you read the speech, that the Catholic question is the chief, but there are also other topics on which some statement must be made both to friends and to the public. (Harewood MSS.)

\section{0o. George Canning to the Marquis of Lansdowne.}

Io May.-If I had not unluckily appropriated tomorrow morning to an interview with the Bank, and other Treasury business (which I cannot now postpone) I should have requested, upon the receipt of your first letter today, the pleasure of seeing you tomorrow. That which I have just received, makes me more anxious to do so. ... I I have only a very imperfect notion of Lord Grey's speech of this evening. Such as it is described to me, it seems incredible that any man should have improvised such an oration on a casual petition.

(Harewood \& Bowood MSS.) 


\section{THE FORMATION OF CANNING'S MINISTRY $22 \mathrm{I}$}

\section{0r. Lord John Russell to the Marquess of Lansdowne.}

II May.- . . I cannot resist telling you how much I feel for you in all the anxiety you have gone through, and that I am persuaded, taking all circumstances into account, you could not have decided better. I am anxious likewise to say that a note I wrote to you some time since, approving of the conduct at Brooks's, was founded on partial information. I wish you had never been interfered with, and I rejoice that for the future you will be able to act on your own just sense of honour, without being met at every step by the conversation of the clubs, the rumours of the Stock Exchange, and the coarse advice of the newspapers. I will only add that while I have a seat in Parliament (which may not be long) I shall endeavour to support Government generally, for your sake, and not for $\mathbf{M r}^{\mathbf{r}}$ Canning's. . . . My father comes to town Tuesday. I believe he will take his seat, and if he attends, sit with Lord Grey.

(Bowood MSS.)

302. Lord Ellenborough to the Duke of Wellington.

I6 Park Lane. II May.-Will your Grace consider whether you and your friends could support a motion for an Address to the King praying that his Majesty will be graciously pleased to proceed to the final reconstruction of the Administration ? If such a motion would have the support of your Grace and your late colleagues, I am ready to make it on Monday or Tuesday next ; but if it should be thought that such a motion would come with more grace and effect from Lord Harewood or any other Peer I am by no means desirous of putting myself forward.

[PS.] I have already written to Lord Eldon on the subject. (Add. MS. 40306, ff. 259-60.)

\section{George Canning to the Marquess of Lansdowne.}

I3 May. - The question which we have to decide is a very difficult and complicated one. I will state to you frankly upon what part of it $m y$ mind is made up ; and upon what parts I think it must rest with you to come to a decision. The Duke of Devonshire's letter [No. 297] (which I enclose) constitutes the first of these divisions of the subject. I cannot remain in possession of that letter, without answering it : and I cannot answer it, without the risk of bringing forward again in a more prominent form, the difficulty on which we 


\section{THE FORMATION OF CANNING'S MINISTRY}

had nearly split a fortnight ago ; and which I thought you had been disposed to put aside and keep out of discussion. A formal declaration on your part must induce a formal reassertion on mine, as my silence under such protest might be construed into an acquiescence. Supposing this difficulty out of the way, the questions which appear to remain are

First, will your accession in the mode proposed cure the awkwardness of the present state of things?

2 If it will not do so (to any very great degree) will it have other beneficial effects, sufficient in themselves to recommend it?

3 Does the pendency of $\mathrm{M}^{\mathrm{r}}$ Beaumont's notice ${ }^{1}$ render the present moment advantageous or otherwise for the proposed accession?

To the first of these questions I should be inclined to answer (but with some hesitation) in the negative. To the second I answer without hesitation in the affrmative, as, with a view to our official co-operation a few weeks hence, I think it highly desirable that you should be cognisant of all that the Cabinet may have under discussion, during the interval. The third can only be decided by you, or rather by those of your friends who are in the House of Commons. I have personally no strong opinion, and no particular wish upon it. I have thought that it might be convenient to you to know my present impressions (after consultation as you may suppose with others) preparatory to our meeting tomorrow.

(Harewood \& Bowood MSS.)

\section{Lord Lansdowne's Memorandum on Catholic Question.}

[Received by Tierney, I3 May.]-The Catholic question is to remain, as in Lord Liverpool's Government, an open question, upon which each member of the Cabinet is at perfect liberty to exercise his own judgment in supporting that question, if brought forward by others, or in propounding it in the Cabinet or to Parliament. But if any member should deem it an indispensable duty to bring forward individually the Catholic question in Parliament, he is distinctly to state that he does so in his individual capacity.

(Tierney MSS.)

1 On the IIth $T$. W. Beaumont asked Sturges-Bourne whether he considered his appointment only provisional. Receiving an uninforming reply, Beaumont said he should bring before the House a motion respecting the manner in which the Home Secretaryship and other offices were then held. (Parl. Deb., N.S., xvii. 744.) 


\section{THE FORMATION OF CANNING'S MINISTRY}

\section{James Abercromby to George Tierney.}

Monday evening, [? I4 May].-I find myself in a very painful situation, and therefore I must entreat your indulgence. I am very willing to do all I can to promote the good of the cause in which we are engaged, but there is a point beyond which I cannot go. The question which I have to decide is, whether there has been any change of circumstances since I agreed to accept office, and if there has, whether that change is such as materially to affect the conduct I ought to pursue. The change is to be found in the consequences that have followed from the Duke of Devonshire's interference. It might be desirable, if it was practicable, to place everything on its original footing at the time when Lord Lansdowne and $\mathrm{M}^{\mathrm{r}}$ Canning agreed to the provisional arrangement. It is very possible to do so with respect to you and others who are not necessarily called upon to take any step at present, but it is impossible for me who must act, to shut my eyes to the events that have occurred. The delay in moving the writs has necessarily convinced our friends that some negotiation has been going on, and they are, in fairness, entitled to ask whether I now feel as confident in my expectation that Lord Lansdowne will become an efficient member of the Government as I did when I agreed to accept office. The answer to this question will be found in my conduct, and if I now accept office, I consider myself in the same situation as if I was to declare upon my honour that I believe the prospect of Lord Lansdowne's coming into office to be undiminished. I cannot say that I do believe it to be undiminished. All difficulties as between the parties are removed and the advantages that will result from Lord Lansdowne and you coming into the Cabinet at this time are strongly felt and seen by our friends, and as I believe, by the public also. Any hesitation on the part of $\mathrm{Mr}^{\mathbf{r}}$ Canning therefore, to complete the arrangements so far as is now practicable, necessarily raises real doubts. The reasons assigned for this hesitation are not at all satisfactory and appear to me to be very discouraging as to the future. It is said that to revive the discussion about the formation of the Irish Government might endanger the safety of the existing order of things. There might be weight in this argument if you asked for stipulations or pledges, or if you even proposed any alteration at this time. But you do no such thing-you make no stipulation, you ask no change, you leave all open for future consideration. If this cannot be safely stated, I can have no confident hope of your being able eventually to over- 


\section{THE FORMATION OF CANNING'S MINISTRY}

come real difficulties, so as to hold out any rational expectation of your coming into office. I rely first on the hesitation in acceding to the proposed arrangement after everything has been settled between the contracting parties, and next on the evidence we now have of the resistance and danger to be apprehended from the King's opinions on the subject. These are new, material, and for my purpose, conclusive facts. I do not think that the prospect of Lord Lansdowne's ultimate accession to office is diminished. The best, if not the only reason for my taking office now, is to confirm the opinions and confidence of others. I am supposed to know what is passing and my act is taken as a pledge of my individual opinion. I must therefore be governed, not by the belief of others but by my own. Unless I so act I am guilty of deception. If you all come in, well and good-if not I cannot consent to be put forward as a puppet to countenance an opinion I do not entertain. A small portion of belief in the future, is sufficient for those who are to wait-but those who are to act now are bound to have a sincere and honest belief. That belief I have not, and without it, I cannot consent to act. I write this letter in order that you may be prepared, in the event of Mr Canning not wishing that you should all, with the exception of Lord Carlisle, come in now. It would be very painful to me to discuss this subject with Lord Lansdowne, and I entreat you to talk it over with him and Lord Carlisle. I am ready to discard, as I have done, and am now doing, all considerations of personal interest, but I cannot give a public pledge inconsistent with my real feelings. (Tierney MSS.)

\section{Viscount Dudley and Ward to Lord Lansdowne.}

Foreign Office. Wednesday, I6 May.-Upon coming here this morning I heard with great pleasure that the final result of the negotiations was to be your immediate entrance into the Cabinet. A political union betwixt yourself and Canning is what I have long and earnestly desired, but till quite lately without venturing to look forward to it as a probable event. Once accomplished, it can hardly fail to grow firmer by intercourse and co-operation. I am sure that there exists between you no difference of opinion that should prevent you from being members of the same Government. It is unfortunate, I think, both for the country and for yourself, that you have been so long prevented from taking any share in the direction of its affairs. But the Administration starts with every appearance of strength, 
and I hope that you are at the beginning of a long period during which your excellent abilities, rendered as they are, more valuable and efficacious by every advantage of station and character, will be employed in the public service. I am the more glad of your early accession because I am convinced it is of the greatest consequence that you should be informed of everything and have an opportunity of giving your advice upon everything from the beginning. Though I shall stay but a very short time in office-the shorter the better, as the Session is to be the term-yet I hope to see you here sometimes before I go. There is a good deal going on that will interest you, and with which it is necessary that you should be acquainted.

(Bowood MSS.)

\section{George Canning to George Tierney.}

I7 May.-As I think you mentioned the probability of your being obliged to go to your election, will you allow me to beg that, if possible, I may know the inclination of your mind upon the matter * which I proposed to you, before you leave London? I am very unwilling to hurry you. But I have received an intimation from the other party to the appointment, saying that there are " pressing inquiries " at the East India House as to whom the Government propose to recommend.

* Endorsement : "Governor Generalship of India."]

(Tierney \& Harewood MSS.)

\section{Henry Hobhouse's Diary.}

Thursday, I7 May.-Mr Canning has at length announced the completion of his Cabinet by the addition of the Marquis of Lansdowne, the Earl of Carlisle, and Mr Tierney; the former without place, $\mathbf{L}^{\mathbf{d}} \mathbf{C}$. with the subordinate office of First Commiss ${ }^{\mathbf{x}}$ of Woods and Forests, wch has never yet entitled its holder to a seat in the Cabinet; and Mr T. with that of the Master of the Mint, wch has always been similarly circumstanced, except in the single instance of $\mathrm{L}^{\mathrm{d}}$ Maryborough, who during the D. of Wellington's remaining on the Continent was put into the Cabinet out of compliment to him and as it were his representative. No reason is yet assigned for $\mathrm{L}^{\mathrm{d}}$ Lansdowne's not taking office.

(Hadspen House MSS.) 


\section{THE FORMATION OF CANNING'S MINISTRY}

\section{J. C. Herries to Robert Herries.}

[A fragment.] [c. I7 May.]- . . the whole of the Treasury, deliberative \& executive, having rested entirely on my shoulders. Canning has not yet bestowed the least attention upon his office \& Lord Goderich threw it all overboard as soon as his patent was completed. The Whig junction will now take place forthwith. Lord Lansdowne will be in the Cabinet without an office \& Tierney with the Mint. What this may lead to God knows! I think it will sooner or later relieve me of the trouble $\&$ fatigue of this office. . . .

(Herries MSS.)

\section{The Marquess of Lansdowne to George Canning.}

Berkeley Square. Friday.- . . . As I understood you would go to Windsor on some early day to settle finally with the King as to the arrangements which have been suspended till the close of the Session, I am anxious to say that the only view in which I could possibly regret the addition of three (permanent) members of the Cabinet beyond the number stated at the time of our first communications; would be its presenting any obstacle to strengthening the Government now or hereafter in the House of Lords, which upon the most deliberate reflection, I am convinced you will find expedient if not necessary in the next Session. They are all three ${ }^{1}$ persons with whom both as individuals and as your friends, I must feel happy to act ; but it is certain as indeed you seemed to anticipate that the Government will, thus constituted, remain so numerous as to make any future accession, however desirable in itself, a matter of no small inconvenience and difficulty. Having once however stated, as I think it right, the apprehensions I entertain, I shall without plaguing you further on the subject, leave it entirely for your own consideration.

(Harewood MSS.)

\section{Ir. George Canning to the Earl of Carlisle.}

Downing Street. I8 May. Private.-Are you in such habits with the Duke of Rutland, that you could arrange a meeting between his Grace \& me at your house ? I have occasion to speak to him. I do not know him well enough to propose his calling upon me (nor would

1 Sturges-Bourne, Lord Dudley, and the Duke of Portland. 


\section{THE FORMATION OF CANNING'S MINISTRY}

it be desirable that his visit should be in the newspapers) and to call upon him would be still more objectionable. If you could manage this meeting for tomorrow morning, between eleven \& twelve, it would be the most convenient time.

[PS.] You are aware that you are to kiss hands tomorrow.

(Harewood \& Castle Howard MSS.)

\section{George Canning to Sir William Knighton.}

F.O. I8 May.-I think it right that you should know that $\mathrm{L}^{\mathrm{d}}$ St Helens's proxy is held by Lord Digby who is understood to be an enemy to the Corn Bill, \& will probably therefore be given in opposition tonight. No Govern ${ }^{t}$ can stand a Lord of the Bedchamber voting against it. Lord Harcourt's is in the same hands-but as to that, as $L^{d} \mathrm{H}$. has not office, nothing can be done. $L^{d}$ Sydney is favourable-so is Lord Courtown.

(Ann Arbor MSS.)

\section{George Canning to the Marquess Wellesley.}

Downing Street. 24 May. No. 3. Private.-I am told that the usual course of originating the nomination of Law Officers in Ireland is that the person in my situation should write to the Lord Lieutenant to signify the wishes of the Govt here : subject, of course, to any representations which the $L^{d} L^{t}$ may have to make upon what is thus conveyed to him. Subject therefore to that opinion on your part, and taking for granted that no promise or expectation has been held out to any person in Ireland, I am to mention to you the name of $\mathrm{Mr}^{\mathrm{r}}$ Sergt Joy, the present Solicitor, for succession to the Attorney Generalship, and that of $\mathrm{M}^{\mathrm{r}}$ Doherty for the succession to $\mathrm{M}^{\mathrm{r}}$ Joy. The new Attorney General must be apprized that the first vacancy in any of the chiefships of the Courts is destined for his predecessor. The necessity of having at least one of the Law Officers of Ireland in Parliament is the motive for selecting $\mathrm{M}^{\mathrm{r}}$ Doherty, who is already there, among many competitors for the office of Solicitor General. The Lord Chancellor has submitted these nominations to the King. (Add. MS. 37297, ff. 283-4.)

Ibid. No. 4. Most Private and Confidential.-In my private letter No. 3 of this date I scored the passage " taking for granted that no promise or expectation, \&c.". The King has somehow a notion that promises had been made to Sergt Leffroy. By whom? 


\section{THE FORMATION OF CANNING'S MINISTRY}

With what authority? The Lord Chancellor knows nothing of any such promises, nor do I. And surely the $L^{d}$ Chancr of Ireland cannot have thought himself warranted in making such. The Chancellor and I had agreed to postpone the Law arrangement until after the issue of the Dublin University election. And I am not prepared to say that our decision might not have been in some degree affected by Sergt Leffroy's success-which would have placed him in Parliament. But nothing of this sort was held out by either of us to anyone, that I know-though it may have been mentioned to the King as a cause of postponement. This it may possibly be that has excited the notion in the King's mind of something like an eventual expectation on the part of Sergt Leffroy. (Ibid. ff. 285-6.)

\section{Lord Binning to George Canning.}

London. Saturday [26 May].-I have received from Sir George Clerk an answer to the indictment preferred to you against him by some person or persons unknown [No. 293]. He pleads Not Guilty. His letter is too long to send you. He utterly denies the fact. He says " Firmly believing that the Government will be permanent, and being I assure you most anxious for its success, nothing short of insanity could tempt me to take so novel a method of recommending myself to the freeholders of this County as that of disparaging the Administration under which I had accepted office." He adds that he should esteem it a favour if you would give me any information that would enable him to trace this report to its source. He has not he says, uttered a word to any of the Whig Party on the subject of the late changes. To Lord Melville's friends he has expressed his regret at his resignation, and the hope that he might again be connected with the Government, stating at the same time that Melville had no ground of complaint, public or private, against you, and that he was not convinced of the necessity of his resignation by his own statement. He does not recollect to have said anything to any of them on the subject of the stability of your Government. To his own relations who questioned him as to the prudence of connecting himself with the new Administration, he answered that this consideration did not enter into his mind when he accepted the proposal made to him in so flattering a manner, but that he had very little doubt but that you would be supported by Parliament, and that your Government would merit and possess the confidence of the country. $\mathrm{He}$ refers to the language he had held to the Solicitor General as being 


\section{THE FORMATION OF CANNING'S MINISTRY 229}

very different from that imputed to him-and the Solicitor you will remember emphatically bears him out. For the first three days that he was at Edinburgh, he was occupied in visiting his constituents, and satisfying their doubts about the popish question. The next five days he was alone at his place in the country, where he communed with no man, and this his retirement must he says have been the period when he was represented as talking so improperly. $\mathrm{He}$ is desirous of hearing from me whether you are satisfied with this explanation, he being grievously annoyed that you should have believed him capable of conduct "so absurd and unworthy of any man endowed with any honourable feelings." I never had a doubt that such would be the character of his reply-for he is both a sensible and an honest man, and I felt quite sure that he had been grievously misrepresented to you. It turns out to be a gross calumny. It is singular that they should have picked out two men so perfectly upright as John Hope and Clerk for the purpose of what I cannot doubt to be very interested misrepresentation.

(Harewood MSS.)

\section{Henry Brougham to George Canning.}

Holland House. Sunday morning [27 May]. - I am anxious, at the risk of importuning you, to renew the conversation which was broken off yesterday evening at Gloster House, because the subject of it hangs very heavy on my mind personally, and because I am quite certain very injurious consequences will arise from the neglect of it, both to the profession and to the Government as regards its weight with that very powerful body (the successor of the priests in this country). But I really have no hesitation in saying to you that great as my feeling is for the Ministry, I am at present more influenced by my personal feelings respecting the individual, and by a sense of justice. Whatever offence may have been created in any quarter; I am quite certain, nay $I$ know that none was intended during the whole affair of 1820 or I821. I know that the historical reference which has been much talked of and not a little misrepresented, was never conceived by Denman himself to bear any application except to the present Master of the Rolls, of whom he had certainly an unfavourable opinion and had expressed it by quotations and allusions more than once before. That he had never felt or showed the least harshness or disrespect towards a much higher quarter I am particularly certain, because I know the uniform and 


\section{THE FORMATION OF CANNING'S MINISTRY}

warm support which he had given me throughout the negotiationswhen he had joined in all my attempts to bring about an accommodation first by preventing the Queen's arrival and then by arranging her retirement. He had gone with me to the late Lord Chancellor when we both offered to suspend our taking of rank at the Bar as Queen's Counsel (which was expected to interrupt the pending negotiations and which certainly did so eventually) and to go within the Bar as King's Counsel. In conducting the case I frequently differed with my learned and able and excellent colleagues and sometimes decided against them. I have no recollection of ever differing with him except on a point wholly wide of any allusion to the high quarter in question, though certainly of great anxiety and moment as to the cause (the closing the case without calling certain foreign witnesses). But this I distinctly recollect, that he stood by me in resisting the line of defence so loudly called for in many quarters in and out of Parliament, and by persons nearest to the Queen-I mean by recrimination, and for which the preparations were completed. I am bound to add that his standing by me wholly deprived him of any special share in the Queen's confidence, because it exposed him to the same absurd suspicions of lukewarmness in her cause which I myself laboured under-only because my discretion was sounder (certainly not my zeal less) than that of many others. In I82I, when the Queen resolved to go to the coronation and required me to accompany her into his Majesty's presence I refused, and so did he, though distinctly menaced with dismissal, and he joined in my verbal and written opinion and remonstrance on that proceeding. The result was that she did not see him on her death bed, and did not name him an executor. I am bound to add that in his whole conduct professionally in and out of court, throughout that most painful and anxious, though I shall ever think to me glorious scene, he deserved and had my entire approbation as his leader, and that to the best of my understanding, if any fault was committed upon the occasion most referred to, it was utterly unintentional as regards the highest quarter. Nor was I aware nor ( $\mathrm{I}$ believe and may say I know) was he aware of the invidious turn given to the application for some time after, when it was too late to do more than regret and disclaim. ${ }^{1}$

Probably you are imperfectly acquainted with our professional etiquettes and feelings on the matter of rank. From accidental

I For Denman's classical allusions in his speech in defence of Queen Caroline, see Arnould's Life of Denman, i. r7r-3. 


\section{THE FORMATION OF CANNING'S MINISTRY 23I}

circumstances it had long ceased to be of any importance whatever to me, and nothing could have so well agreed with my individual interests as the Chancellor leaving things in their present conditionthat is, making no promotion at all. My request has uniformly been, therefore, that he would promote nobody, as if he did, I should run a risk of competition on the Northern Circuit which I am now wholly free from-and as I saw that I might be forced to take rank if others did in self defence-a step to be avoided both for public and private reasons, he felt unable to comply with this, and I then was desirous that he should leave out our Circuit, in which case I might run the risk of letting men of other Circuits go over my head. This too was found impossible and their remonstrances to me at length drove me from that ground-I should in the opinion of some be seriously injured if not ruined on the Circuit which I now lead, were I to stand still and let others be promoted. My own opinion is different-but a risk undeniably there would be--I cannot more strongly describe my feelings on the subject of Denman's exclusion than by saying that this risk I had instantly made up my mind to run as soon as I learnt the difficulty of touching his promotion-and I have only been induced to abandon the resolution by hearing that my refusal if persisted in must needs be taken to show an undue sense of the very great kindness and condescension which has met the Chancellor's application for my rank - and of the gracious manner in which I have been since mentioned. Anything of this sort or liable to this misconstruction would be in the last degree unbecomingbut painful as it would be to inflict the injury on others of the profession which my refusal would occasion, I should not have felt myself at liberty to regard that consideration. Suffer me, after saying so much of myself, to add a few words respecting the profession and the Crown's patronage. Something will happen on the Midland Circuit and in London, like what my want of rank occasioned on the Northern. Rank will be disregarded, and so great an advocate as Denman will be followed without it - for even in my case it has been wholly disregarded these six years past-to the very serious injury of all above me-to the great discontent of the profession and to the utter ruin of the Crown's patronage in the profession. These matters you ought to know and weigh, for we may all hear of them in Parliament in the course of the discontents which promotions always leave behind them.

I hope you will excuse my great anxiety on this occasion. If there is one thing in the world which I desire to avoid it is the 


\section{THE FORMATION OF CANNING'S MINISTRY}

occurrence of any public discussion to revive the heats of 1820 and I82I, or even to occasion any allusion to them. This combines with my feelings of most sincere private friendship towards Denmanto make me feel very unhappy upon the difficulty which has arisen. I need hardly add that my own personal interest is all the other way, for if there be a thing more certainly beneficial to me than any other which could be named-and that directly and immediately (I mean sure to produce its effects within four and twenty hours) it is his exclusion and my promotion. These feelings must be my excuse for troubling you with so long a letter.

(Harewood MSS.)

\section{The Countess Cowper to Frederick Lamb.}

Panshangar. Monday, 28 May.- . . Brother George is getting quite stout again, all the political arrangements do very well and the Govern $^{t}$ in all probability likely to last a great while. There was a strong majority of 57 in the Lords on the Corn question, and it is thought there will be no more difficulty about the Bill. L $L^{d}$ Egremont is very silent ; it is thought that he does not like the present arrangements but he says nothing. ... .

(Broadlands MSS.)

\section{Lord Seaford to Viscount Granville.}

Audley Square. 29 May.- . . Upon intimations that the Duke of Wellington would not be indisposed to return to the command of the army, Canning transmitted to the Duke, in a letter of his own, one from the $\mathrm{K}$ [ing], written in the kindest stile, beginning, "My dear Friend," and ending by saying that " the command of the army was still open and that there was no reason why the Duke should not recall that resignation which he (the $\mathrm{K}$.) had received with so much regret." To this the D. of W. has replied that " the reasons for his resignation of the command of the army, as stated in his former letter, appear to him to remain still in force, and that, under those circumstances he could not recall his resignation of the command of the army, without rendering himself unfit to serve the $\mathrm{K}$. effectually in that situation "-or something to that effect. In the previous part of the letter the D. refers to the "rebuke" which had (as it appeared to him unnecessarily) been conveyed to him by Canning and the " proof which it afforded of a want of that confidence in him 


\section{THE FORMATION OF CANNING'S MINISTRY 233}

which was essential to the public service." Canning had written a letter to Lord Anglesey (who had had some previous communications with the D. of W., and had endeavoured to convince him of the erroneous construction which he had put on C[anning]'s first letter) and in that letter had disclaimed the intention of conveying any rebuke, and appealed to the fact of his transmitting the K's letter, containing the permission to recall his resignation as affording the practical refutation of the "want of confidence." But upon reconsideration he has determined not to send that letter-which I confess I regret-as does Huskisson. And so the matter rests, broken off, upon the D. of W's refusal. His friends take exception to the phrase "recall his resignation" - which they say is an insult, and inserted by C[anning] as a "ruse" in order to spoil the friendly tone of the rest of the letter. In this there is not a word of truth-for this phrase and indeed the whole letter, was the $K$ 's own-and it only proves, like the " rebuke," a captious disposition and irritated state of temper, which would make it extremely difficult for the $D$ [uke] and $C$ [anning] to be brought together again, and still more so to act together cordially. But without looking to any such result, I think, even the quarrel would have been a better one, after the explicit declarations contained in the letter to Lord Anglesey.

You will see in the papers our division on the Corn Bill which was prater spem-and the debate you may read if you have a superabundance of patience. Lord Lansdowne spoke very well indeed. There is no doubt now of our carrying the Bill.

Last night you will see Canning was in a minority on the question of disfranchising Penrhyn. I have not had time this morning to read the debate. But I hear the division was very much affected by the absence of the ultras at the Pitt Dinner-and that C[anning] treated the question as one merely judicial-so that it cannot fairly be considered as in any degree a test of his political strength. Sandon I am told made a very reforming speech and voted against $C[$ annin]g.

You will I am sure be glad to hear that $C$ [anning] has made demonstrations of kindness towards Holland, by applying to Herbert Taylor to forward Charles Fox's application for promotion-and also by leaving Fox chargé d'affaires at Naples. Holland is to dine with him on Saturday with Brougham and other Whigs, and a mixture of our own colour, among which myself.' Morley is in a state of perfect contentment ...

$$
\text { (P.R.O., G. \& D. 29/9.) }
$$




\section{THE FORMATION OF CANNING'S MINISTRY}

\section{The Marquess of Lansdowne to Lord Holland.}

B. Sq $q^{e}$ 3I May.-[Charles Dundas wants a peerage] . . . It is impossible for me, however, circumstanced as I am, to make him any sort of promise, except that if he wishes it at any time I will state his wishes and claims to $\mathrm{M}^{\mathrm{r}}$ Canning. You know that $\mathrm{I}$ have at no time considered myself, or ever allowed myself to be considered by others as a party leader, nor would it have been possible for me in accepting office upon publick grounds at the present juncture to have undertaken it with any expectation or hope of satisfying old party claims either with respect to promotions or to offices, tho' I should be happy in any opportunity which offered to shew my respect for individuals so well entitled to it as I believe $\mathrm{M}^{\mathrm{r}}$ Dundas to be. ${ }^{1}$

(Holland House MSS.)

\section{3r9. George Canning to the Marquess Wellesley.}

Downing Street. I June. Private and Confidential.-Sturges Bourne has received this morning a letter from the Lord Chancellor of Ireland, objecting strongly to Doherty's appointment. He treats it as an affront to the whole profession. Now, I have no desire to do anything affronting, or even unfair to the profession. But we cannot go on here, without one of the Irish Law Officers in Parlt. Doherty is already in Parlt by his own means. He is at the head of his Circuit in Ireland, and I was, and am, advised that he is eminently qualified for the office for which he was recommended. However, I have desired S. Bourne to write to Lord Manners to say that nothing further shall be done in the matter, till we have his opinions at large upon the proper selection. $L^{\mathbf{d}} \mathbf{M}$. says he has not seen you. Perhaps you had better call upon him for a list of persons from among whom he thinks that the selection ought to be made, which you may transmit for consideration. But he is not to suppose that we can adopt his single nomination. This mode of proceeding will keep you out of hot water-which above all things I desire.

(Add. MS. 37297, ff. 335-6.)

1 Charles Dundas, M.P. for Berkshire, was created Baron Amesbury in 1832 . 


\section{The Marquess Wellesley to George Canning.}

Phoenix Park. 2 June. Saturday morning. No.2. Private and Confidential.-Lord Norbury has at length resigned. I saw him after his Court late on Wednesday evening. He was at first quite intractable, and seemed to despise the Irish peerage, but upon my dropping a hint of the probability of another arrangement, ${ }^{1}$ he immediately changed his course and desired a day's delay for consideration. This request I could not refuse.

Yesterday morning I received the inclosed letter, which I forward to you in the original, as a curiosity. I shall immediately transmit to $\mathrm{M}^{\mathrm{r}}$ Bourne the recommendation for Lord Norbury's Earldom (for so it must be) with remainder to his second son; and also for his pension of retirement; and I shall at the same time forward the usual official recommendation of Lord Plunket. I am not quite certain whether the remainder in Lord Norbury's peerage will not constitute a new grant of peerage ; there are now sufficient vacancies to enable the King to create one Irish Peer. If this should be the state of the law, no peerage can now be granted to the Chief Baron. But some lawyers think that this remainder does not affect the King's right in consequence of the vacancies, to make a new creation now. In this view I believe the Chief Baron ${ }^{2}$ would be willing to resign; $\mathrm{M}^{\mathrm{r}}$ Joy might then succeed him, $\mathrm{M}^{\mathrm{r}}$ Lefroy might be Attorney and $\mathrm{M}^{\mathrm{r}}$ Doherty Solicitor General, and $\mathrm{M}^{\mathrm{r}}$ Wallace might be Sergeant in room of $\mathrm{M}^{\mathrm{r}}$ Lefroy. This arrangement would probably calm the present agitation. Be so good as to let me know your wishes. I recommend it to you to advise with Lord Plunket.

(Add. MS. 37297, f. 339.)

\section{The Marquess of Lansdowne to George Canning.}

Berkeley Square. Saturday morning [2 June].-I was assured last night by some persons connected with Ireland that $\mathrm{M}^{\mathrm{r}}$ Doherty's appointment was resisted by Lord Manners, and as you may be called upon to take some step on the subject immediately, I am unwilling to delay till I see you this evening saying that I hear from different quarters that it has given the greatest satisfaction in Ireland, and that the disappointment will be in proportion if it is

1 An English peerage.

2 Standish O'Grady, Lord Chief Baron of the Court of Exchequer in Ireland. 


\section{THE FORMATION OF CANNING'S MINISTRY}

withdrawn-indeed so much so as to alter very much the view which persons there may be disposed to take of the authority and intentions of the Government here.

The division of last night in the Lords was the result of a combined movement of all who for different reasons are ill disposed to the Government. I trust that by an effort (the numbers voting being. considerably less than on the former night) the amendment may be got rid of on the report, otherwise it will prove fatal to the Bill. ${ }^{1}$ (Harewood MSS.)

\section{George Canning to the Marquess of Lansdowne.}

Downing Street. 4 June.-If you had not been gone to Richmond. I should have wished very much to see you today, to report what passed with the King yesterday respecting the recusants of the Household, and also to show you a letter which I have just received from his Majesty (on his leaving town) in which, referring to the lax attendance of the Bishops, his Majesty authorizes me to "do whatever I please to show them that the King is sincere and in earnest." These are the concluding words of the King's letter which I shall "show" to one or two of the Reverend Bench in the course of tomorrow, and with the aid of which I hope we may reckon upon turning round the Duke of Wellington's furtive vote in the Committee on Monday.

(Harewood \& Bowood MSS.)

\section{The Marquess of Lansdowne to George Canning.}

Richmond Hill. Monday evening [4 June]. - I am much obliged. to you for your satisfactory account of what has passed respecting the strange proceeding in the House of Lords. With that and the stray votes we are picking up, I have no doubt the blot will be effaced, and in that case certainly nothing will have been gained by those that made it. . . .

(Harewood MSS.)

1 Wellington's amendment to the Corn Bill, providing that no corn in bond should be taken out of bond until the average price amounted to $66 \mathrm{~s}$., was carried by 78 to 74 . 


\section{THE FORMATION OF CANNING'S MINISTRY 237}

\section{George Canning to Henry Brougham.}

4 June.-I have not failed to communicate to the Lord Chancellor the letter [No. 3I5] which I had the honour to receive from you this day sennight. This was all that I could do, in a matter which is not officially of my own concern, and in which personally my interference would be at least unwelcome. I shall always be ready to bear my testimony to the anxious zeal which you have manifested in behalf of your friend.

(Harewood MSS.)

\section{George Canning to Sir William Knighton.}

$D^{a} S^{t}$. 5 June.-I wrote to $L^{d}$ Farnborough last night to ask after $L^{d}$ Brownlow's politicks. $L^{d} F$. would certainly give the most favourable account of them that he could-but you see the result ! Is it possible without humiliation \& evil enough, to confer the favour of the Crown on a person standing in such relation to the Govt ? 1

(Ann Arbor MSS.)

\section{George Canning to the Marquess Wellesley.}

Downing Street. 5 June. Private and Confidential.-Your negotiations have been most successful. There can be no doubt, I think, and the lawyers here think (which is more to the purpose) that Towler's [? Toler's] Earldom absorbs three vacancies. But you do not appear to be aware that there are six-one of which indeed requires till March to ripen ; but surely the Chief Baron would take the word of the Government for six months. In that case, nothing could be more desirable than the arrangement which you propose, as reconciling all interests and feelings-the feelings of the Lord Chancellor himself, I hope, included. Pray have the kindness to satisfy his Lordship that I never had it in contemplation, intentionally, nor ever believed that in the proposal which I transmitted to you I should have the ill fortune unintentionally to run against his Lordship's opinion or the prejudices of the Irish Bar, in the way in which his letters (to you and to $\mathrm{M}^{\mathrm{r}}$ Sturges Bourne) appear to indicate. Here we have no such deference for precedency. The nomination of Lord Gifford from a stuff gown on the Western Circuit-and more

${ }^{1}$ He voted against the Corn Bill. 


\section{THE FORMATION OF CANNING'S MINISTRY}

recently of $\mathrm{Mr}$ Tindal from the Northern Circuit, to be Solicitors General, over the heads of all the Silk Gowns, both of those particular Circuits and of the whole Bar-are evidences that the Govt here makes its choice without reference to such punctilio, and at the same time without any apprehension of " outraging " the profession. However, I shall be a thousand times better pleased that all parties shall be pleased, as I trust they will be by your arrangement. $M^{r}$ Wallace is known to me by reputation, and I rejoice in his promotion. It is but fair to $M^{\mathbf{r}}$ Doherty to say that so far from having: made any application, or having been taken into counsel upon the occasion-he is at this moment-for aught that I know or am answerable for-in entire ignorance that his name has been, or is, in question. I have neither seen him myself, nor authorized any communication to him. I presume that the Lord Chancellor's wish to leave the appointments to be sanctioned by the Commissioners does not apply to the present arrangement.

(Add, MS. 37297, ff. 34I-3.)

\section{Lord Seaford to Viscount Granville.}

A[udle]y Sq. Tuesday; 5 June.- . . . I am not sure that I quite agree with you in regretting the steps which were taken to induce the D. of W[ellington] to resume the command of the army. There was a very strong and general feeling of regret at his not being in that situation. And there is an advantage in having a full and complete case against him. His refusal has also shewn him to be under the influence of very intemperate feelings, and tells back on his past conduct very much to his disadvantage. That impression has also been strongly confirmed by the trick which he played us in the Committee on the Corn Bill on Friday, moving an amendment which he stated to be framed in uniformity to a suggestion from Huskisson, and on Goderich's saying that he could not accede to it, reading an extract of a letter from Huskisson, and omitting the concluding sentence in which Huskisson warned him that such an amendment "would be fatal to the Bill." His amendment was also most essentially different from that modification of the measure which Huskisson in his letter stated that he individually should not very much object to, adding however the warning that even that would be fatal to the Bill. . . . Planta has promised me a list of the division, which I will inclose when I take this to the F.O. You can analyse it better than I. You will see in the majority three Lords 


\section{THE FORMATION OF CANNING'S MINISTRY}

of the Household-Delawar, Errol and Macclesfield, and two new Ribbands- $L^{d}$ Exeter and Aboyne. The $\mathrm{K}$. is very angry and has given C[anning] his full permission to proceed with whatever severity he may think fit against them, and also has authorised him to convey to the Episcopal Bench, who were scanty in their attendance, an intimation of the K.'s interest in the success of the Bill. We shall try to throw out the Duke's clause on the Report, and as many persons who voted for the Duke's amendment were not aware of its being fatal to the Bill, and $\mathrm{w}^{\mathrm{d}}$ be sorry to throw it out, it is expected that we shall succeed. In the meantime the impression has been very unfavourable to the $\mathrm{D}$. of $\mathrm{W}$. and the ex-Ministers who all voted with him, except $L^{d}$ Eldon, who was absent.

You will see Canning was also in a minority on the Penrhyn question. He says he does not mind it, and he certainly proved his indifference by sending Husk ${ }^{\mathrm{n}}$ away to dine with me. The question undoubtedly was not a Ministerial one. But the ultras urge it as a proof of his little power of controul over the Reformers, and the impression combined with the division on the Corn Bill is not satisfactory. The Budget was admirably executed, and in the clearest stile and perspicuity itself-and the impression on the House quite satisfactory.

He gave a dinner on Saturday of both colours- $\mathrm{L}^{\mathrm{d}}$ Lansdowne, Holland, Carlisle, D. of Devonshire, Abercromby, and Broughamand others-and per contra D. of Portland, the Chancellor, Palmerston, and an etcetera belonging to himself. It went off very well, and what I was very glad to see, Holland was in very good spirits and seemed to like it extremely....

$$
\text { (P.R.O., G. \& D. 29/9.) }
$$

\section{Lord Binning to George Canning.}

Wednesday night $[6$ June $]$. - . . I I have rigidly executed your commission. I saw Lord Macclesfield this forenoon. I find that I was quite right as to the spirit of his vote. There was no political feeling in it-nothing but a strong country gentleman opinion on the warehousing - and its consequences according to the Bill as proposed. He had no idea that he was risking the final passing of the Act, because having consulted Bexley as to the effect of alterations, that personage gave him to understand that the Commons would probably bring in the Bill again as altered by the Lords even if a regard for their privileges forced them to throw it out. Whether 


\section{THE FORMATION OF CANNING'S MINISTRY}

Bexley's answer applied to the clause moved by the Duke of Wellington I am not sure. I mentioned this conversation only as decisive of the unwillingness of Lord Macclesfield to hazard the fate of the Bill, for the principle of which he had voted. His first impulse was to resign, as his conduct had been objected to, and he could only set himself right by a course that would render him liable to the obvious imputation of being actuated only by a desire to retain his office. I argued the matter with him, and tried to convince him that he might consider about retracting a vote given under erroneous impressions of the consequences it was calculated to produce. I prevailed so far that he said he would consider the matter. . .

(Harewood MSS.)

\section{George Canning to Lord Binning.}

7 June, I0.45. Copy.-Your letter of last night reached me only a quarter of an hour ago, just as I was sitting down to breakfast. After Lord Macclesfield's explanation, his Lordship's staying away on the Report would be quite satisfactory to me, and I assure you a thousand times more so than his resignation, either now or after a vote in opposition.

(Harewood MSS.)

\section{George Canning to Lord Seaford.}

9 June.-It is impossible for me to answer C[ourtenay]'s ${ }^{1}$ letter in writing. The time required would be too long, and I must say something which I should not choose to record. That Liverpool should not have told him that he was choosing for life, I confess astonishes me. It was that consideration alone that occasioned (I had supposed) any hesitation in C[ourtenay]'s choice, and occasioned him to ask two or three postponements and reconsiderations. No man could well doubt whether $£ 4,000$ a year or 4 as a mere step onwards was worth acceptance. The doubt was whether it was a wise exchange for other chances or prospects in life. By C[ourtenay]'s present account it appears that he intended both. The certainty in present, and all favourable chances in future. I am sure the option was not so understood by Lord Liverpool. I am sure it was not so understood by $m e$, who had another candidate

1 William Courtenay, Clerk Assistant to the House of Lords since 1826, and previously a Canningite M.P. 


\section{THE FORMATION OF CANNING'S MINISTRY 24I}

to propose, if C. had declined; but willingly sacrificed him to $\mathrm{C}$. C. therefore must not blame me if his name has never presented itself to me for such office as he now appears to have in view. Nor can I believe that any man, judging of any other man than himself, would pronounce a promotion from the Clerkship of the House of Lords to the Lord Chancellorship of Ireland, a natural and likely to be to the profession an acceptable promotion. What I like least in Courtenay's letter is that it appears to indicate that he has been canvassing for opinions among Peers, and Irish ; in short, laying the foundation for a report that he is to go to Ireland-such as was raised two months ago, that he was to be Master of the Rolls-which contributed mainly to my difficulties about Plunket.

(Harewood MSS.)

\section{3r. The Countess Cowper to Frederick Lamb.}

London. I2 June.- . . W $\mathrm{W}^{\mathrm{m}}$ is going off to Ireland about the $20^{\text {th }}$ of this month by which time it is thought the $\mathrm{H}$. of Commons will be up-but it is possible the Lords may sit later as they have still many Bills to pass. I thought I had told you Sturges Bourne was only temporary and D. of Portland and Dudley. I suppose Mr C. will be First $L^{d}$ of the Treasury as well as Foreign Office when the new arrangements take place, his friends say he could not otherwise be sure of keeping the power in his hands, but others think this double place will be unpopular and thought to be grasping. $\mathbf{L}^{\mathbf{d}}$ Holland wants very much now to come in and would like his old place the Privy Seal, as his first delicacy to $\mathrm{L}^{\mathrm{d}}$ Grey has vanished. I think his coming in would be a very good thing as it would conciliate the old Whigs, many of whom don't like and even cannot quite understand the whole proceeding, it's so unlike the year '84. The Govern ${ }^{t}$ is going on very well and strong, tho there is still some doubt if they may not be beat again to-day on the Corn question in the Lords-the putting down the land makes such a cry among the proprietors they can hear no reason about it. Yet I should say that the last division on Duke W.'s amendment when the Ministers were beat, has in fact strengthened Mr C[annin]g as it has shown how decided and how sincere with him the King is-and his giving up his Lords of the Bedchamber to him. They have three sent in their resignations-Errol, Macclesfield and Delaware, but if the Ministers are not beat tonight I should think it would be made up-as it was merely a personal Corn feeling and not any intention to oppose the 


\section{THE FORMATION OF CANNING'S MINISTRY}

Governt. I wish it were possible for papa $^{1}$ to have taken his seat, but it would have been very awkward and therefore better left alone. Duke $W^{n}$ 's behaviour is so childish and foolish that I feel quite grieved about it as it must lower him in public estimationproducing Huskisson's private letter without leave was a wrong thing to do, and then reading only part of it, and as people say putting a different construction on it from the true one, but this we shall hear tonight, and then advising and consulting with $L^{d}$ Grey and the Duke of Bedford; all this is so unlike his general character and acting in this manner from private pique-and in fact so absurd since he looks to a return, to shut the doors against himself. Mrs $\mathrm{A}$ [rbuthnot] is very much now against this course, but he is led by the Chancellor ${ }^{2}$ and Peele and $L^{\mathbf{d}}$ Lauderdale, who of course would find themselves stranded if he left them. There seems no chance therefore of the Duke's returning to the Army at present and as $L^{d}$ $\mathbf{P}$ [almerston] goes to the Exchequer after this Session there must be some arrangement. Ld Anglesey has been talked of as Commanderin-Chief but $I$ hope there is no chance of this-the most probable is that he should go to Ireland when $\mathrm{L}^{\mathrm{d}} \mathrm{W}$. T. [? $\mathrm{Wy}$ ] comes away and Sir George Murray be Secy at War and Cr in Chief, they say he is a good kind of man and a good officer and likely to do it well. Cambridge is out of the question-for they say he is under some sort of restraint at present. The Tory part[? y] is very active and canvassing and trying by civility to get people round to them, Lambton says he had not been six hours in England before he had many messages from them-but he is very decided and staunch - tho he says it is the best opening for a man who wants to be talked of and to make a figure, to follow Peele, as they have none (or hardly any) individuals of talent on that side of the House (in the Commons). We are going to the Kings Lodge on Thursday next and on Friday we are to have there the Duke and Duchess of Clarence, and I am told $\mathrm{M}^{\mathbf{r}}$ and $\mathrm{M}^{\mathrm{Is}}$ Canning, the Lievens are also our party, Carlisles, Agar Ellis's. . . . Evelyn Denison, a very nice person, marries one of the young $L^{y}$ Bentincks, $\mathrm{L}^{y}$ Charlotte, I think a pretty match but the Duchess and the Duke don't like it, they think it not brilliant, he has a tolerable fortune and is one of the $L^{d s}$ of the Admiralty. $L^{y} \mathrm{~W}^{\mathrm{m}}$ Bentinck is going about more bother headed than ever $-L^{d} W^{m}$ is often talked of for India. $L^{d}$ Cowper is hand and hand with the present Governt and despises Lord Grey-you know of old his

1 Peniston Lamb, first Viscount Melbourne (1748-1828).

The ex-Chancellor, Lord Eldon. 


\section{THE FORMATION OF CANNING'S MINISTRY}

partiality for Huskisson. $\mathrm{L}^{\mathrm{d}}$ Dudley and he are quite thick again. Brougham adores me and Lambton and Burdett and Hobhouse, there is nothing more comical than to see the loosenings of some friendships and the tightening up of others, it makes me laugh when I am alone to think of the events of this year, and its effects upon private society, much more than any other political revolution could have done-because it is not measures or principles so much as pique and personal likings and dislikings which influence people. Now to see Lady Jersey crying up her father ${ }^{1}$ after having been laughing at him for the last 20 years, courting $L^{d}$ and $L^{y}$ Londonderry and $L y$ Bathurst whom she hated last year, it is really too absurd. $L^{\mathbf{d}}$ Grey quoting the Duke of $\mathrm{W}^{\mathbf{n}}$ and the Duke quoting him-however I have quarrelled with nobody which is a great thing to say, and tho I grieve over Duke W. he and I are perfectly good friends and as intimate as ever tho I see much less of him, and he is not asked to Windsor of course. Little Saly and I are also very good friends tho he is a malignant and tho he does make a fool of himself always trying in vain to be a speaker and to make himself heard in the House. Ld Jersey is the person who looks most miserable for he finds himself alone and with no friends; the Whigs have left him and he has no resource but wky and the turf-how he can be such a fool as to turn his back upon himself when he is naturally a courtier in grain and has such a good opportunity of being on the winning side-but this comes of having a termagant for his wife as he cares in fact not one straw about politicks. What a long letter I have written to you it almost frightens me to look at! . .

(Broadlands MSS.)

\section{The Marquess Wellesley to George Canning.}

Phoenix Park. Tuesday, I2 June. Private. (Copy.)-I proceeded in my endeavour to forward the general arrangement in the Law Offices of the Crown, which I suggested in my former letters, by ascertaining the views of the Lord Chief Baron. I found him unwilling to resign, until a peerage could actually be conferred upon him, and also until some very extensive pecuniary demands of his Lordship on the Government could be adjusted. The negociation with him is therefore closed for the present, but I add with concern that in the course of conversation with Lord Manners on the subject, I ascertained that his Lordship would have objected as much to the

1 Lord Westmorland. 


\section{THE FORMATION OF CANNING'S MINISTRY}

new arrangement, as to that now under consideration. He stated to me, in the most distinct terms, that he could not concur in the appointment of Mr Doherty to the office of Solicitor General. His Lordship rests his objection $I^{\text {st }}$ on the political and parliamentary considerations, which (as his Lordship says) solely have suggested Mr Doherty's name on this occasion ; $2^{\text {dly }}$ on the superior claims of many others, both in point of seniority and knowledge. I had requested, some time since, that Lord Manners would furnish me with a list of those persons, from whom he wished the selection for the office of Solicitor General to be made. He however declined this proposal from motives of delicacy. In conversation, he has mentioned the names of Mr Serjeant Blackburne, Mr Pennefather, and some others, all, certainly of the same class of political opinions, yet certainly of the highest class of professional merit, and highly entitled to the consideration and favor of Government. If Mr Lefroy were Attorney General, Lord Manners would suggest Mr Sergt Blackburne to be Solicitor; he thinks that Mr Doherty should be satisfied at present with a sergeancy. In this state of the matter it is become indispensable to the public service that the office of Attorney General should be filled, and as Mr Joy is quite above exception and highly approved by Lord Manners, I have thought myself authorized to forward the official recommendation of $\mathrm{Mr}^{\mathrm{r}}$ Joy, and to add to it the usual appointment to the Privy Council of Ireland. Be so good as to apprize Mr Bourne of the state of these transactions. I hope to be able to write to him fully this night. The office of Solicitor General may remain open without much inconvenience until the month of August when the Great Seal here will as usual be in commission. I wish you to understand that throughout all these transactions Lord Manners and I have continued on the most amicable terms, and that nothing of a controversial or unkind spirit has existed between us ; nor has he manifested any symptom of a desire to embarrass the Government. His opinions are stated fairly and with temper, and I entertain no doubt of his sincerity and real candour. It will be very desirable to expedite Mr Joy's appointment as much as possible ; the inconvenience being severely felt of the want of an Attorney General. Hitherto, as you know, it has been unavoidable. The subject of these appointments excites great anxiety and eager discussion. On every other point Ireland is more tranquil than I ever remember ; I am most happy to add that all appearance of distress for food has generally ceased, as far as that distress relates to insufficiency of 


\section{THE FORMATION OF CANNING'S MINISTRY 245}

provisions. The want of employment is greatly felt, but will be in some measure relieved by the approach of harvests.

[PS.] Be so good as to communicate this letter to Mr Lamb. (Add. MS. 37297, ff. 353-5.)

\section{Lord Seaford to Viscount Granville.}

F.O. Tuesday, I2 June.-Since my last, nothing of importance has taken place. We went through the remainder of the Corn Bill in Commee without a division. Tonight we have the Report, and our trial of strength on rescinding the Duke of Wellington's amendment. By the next courier I will write you whatever may be worth sending in the way of commentary on the debate. It is confidently expected that we shall succeed in the division, though not by many votes. It was with great difficulty that I obtained for you the list of the division which I did send. For that department of the Administration is as yet very ill organised. The inference which you apprehend, as likely to be drawn from the votes of De la Warr, Macclesfield and Errol as to the $\mathrm{Kg}^{\mathrm{s}}$ disposition has secured a strong practical contradiction in their resignations, and his interest in favour of the Bill has been further evinced by the intimation which, I am not sure whether I mention[ed] to you or not, that he had authorised $\mathrm{C}$ [anning] to convey to the Bishops. This cordiality has been further testified by his invitation to $C$ [anning] to go to the Cottage, for Thursday and Friday, one not the most natural occasion-Ascot Races. And the truth is that he is as cordial as possible.

Dudley, passing across the room at this moment, put it in my mind to tell you that he spoke exceedingly well, both in answer to a question of Ellenborough's as to secret service money, and on the following day in moving the Address on the K.'s message about Portugal-well, not only in substance but in spirit and tone, and to the general satisfaction of the House. . . .

$$
\text { (P.R.O., G. \& D. 29/9.) }
$$

\section{John George Lambton to Lady Louisa Lambton.}

London. I2 June.- . . You have no idea of the alteration the late political changes have made, even in private society. Most families are divided in opinion; amongst the most violent is Lady Jersey. She and Lord Grey keep up one another's hatred 


\section{THE FORMATION OF CANNING'S MINISTRY}

of Canning, assisted by Lauderdale, who is more venomous and violent than usual. I as you know am for the junction, but endeavour to keep well in private with all. Nothing is yet settled, but is postponed until the Session is over, which must be in about a fortnight. . . . I am sorry to say that Lord and Lady Grey are very angry with him [Sir Robert Wilson] for the part he has taken in the late arrangements, but I shall do my best to soften them towards him.

(Lambton MSS.)

\section{William Huskisson to Viscount Granville.}

Somerset Place. 3 July. - . . . Our Session is now over, and our difficulties postponed. They were formidable enough without the necessity of trying our strength again upon a new Corn Bill at the commencement of the next Session. However I shall not despair of getting people into better humour, if Canning keeps his health, and the King remains firm. Of Canning's health I know not what to say. He looks ill, and very much worn; but he possesses great strength of constitution and his medical advisers are sanguine. Of my own health I am sorry that I cannot report favourably. I have been losing ground again for the last ten days, and am altogether in a weak and uncomfortable state. This makes me very anxious to get away from business as soon as possible. I hope to be on the Continent by the $20^{\text {th }}$, and, after travelling about for a couple of months, to find you and Lady Granville well at Paris before the end of September.

$$
\text { (P.R.O., G. \& D. 29/9.) }
$$

\section{Henry Hobhouse to Viscount Sidmouth.}

Whitehall. 4 July. Private.-After all $\mathrm{w}^{\mathrm{ch}}$ has passed in the political world within the last few months, you will not be surprized to hear of my retirement from the office in $w^{\text {ch }}$ your kindness placed me. And while the interest you have so long taken in my welfare requires that I should give you the earliest intimation of my intention, it emboldens me to obtrude upon your patience a short detail of the reasons on which my resolution is founded.

Sturges Bourne has at length communicated [to] me that his secession from this office, and Lord Lansdowne's accession to it, with $\mathrm{M}^{\mathrm{r}}$ Spring Rice as his Under-Secretary, are resolved on, and 
will soon take effect. I stated to him in reply, that I thought the time was come when I ought to withdraw, and I assigned the state of my health as the immediate reason of my taking that course. This is the truth, tho' certainly not the whole truth. My health $w^{\text {ch }}$ had continued to improve till about the middle of May has since that period been sensibly retrograding, and for the last two days I have felt unpleasant sensations in my head, w $w^{\text {ch }}$ I had lost for several months. I am therefore satisfied that I stand in need of relaxation from business to an extent $w^{\text {ch }}$ would be utterly incompatible with my duty towards a new and inexperienced master. I find moreover that I now want ( $w^{\text {ch }}$ I formerly did not need) some incentive beyond the mere sense of duty to enable me to bear my labours with satisfaction to myself. But instead of meeting with such incentive, every recent occurrence has borne a discouraging aspect. It is irksome to accommodate myself so often to the habits of a new master. And the loss of that confidence $w^{\text {ch }}$ I enjoyed in the highest degree under you, and sufficiently under Peel to sweeten my labours, has since his retirement materially deteriorated my position, and would probably under $L^{d} L[a n s-$ downe] reduce me to a state little better than an article of office furniture. I am not sure whether I mentioned to you that while the doubt hung over the succession to this office in April, I received a message from Canning prohibiting me from from [sic] going into Parliament. When I contrast this with the facility with w $^{\text {ch }}$ a seat has been provided for Perceval, ${ }^{1}$ and when I reflect that in conferring for the first time the rank of a Privy Councillor on an Under-Secretary of State, I have been passed by in favour of one so far my junior as Wilmot Horton, I cannot draw any other conclusion than that $I$ am to expect no advancement either in office or rank during Canning's Administration. This reduces the question of my continuance in this office to the single one, whether the mere salary is an adequate inducement. And that question, under all the circumstances, I have no difficulty in deciding in the negative.

I mentioned to S. Bourne that I intended to apply to Canning

1 Herries informed Lord Yarborough on 18 May that Canning wished to recommend Spencer Perceval, Under-Secretary of State for the Home Department, for the vacancy occasioned at Newport by William Lamb's acceptance of office. " Mr Perceval," he added, "is prepared to stand upon the same footing in all respects as Mr Lamb would have done in pursuance of the communication which took place with $M^{r}$ Sewell when he was in London." (Herries MSS.) 


\section{THE FORMATION OF CANNING'S MINISTRY}

for the pension of $£ \mathrm{I}, 000$ to $\mathrm{w}^{\mathrm{ch}} \mathrm{I}$ have completed my title by ten years' service here. He appeared to think there wod be no difficulty in obtaining it, and offered to speak to $C$ [anning] on the subject. I find that Beckett has asked for his pension on the same fund, but this will not I apprehend stand in my way, as a second will be grantable in the course of the present week. By giving up my house in town and making some other retrenchments in my ménage, I shall be able to bring my expenditure within my means, aided by this pension, without materially curtailing the comforts of my family otherwise than by cutting them off from the gaieties of London. . . .

(Sidmouth MSS.)

337. E. G. Stanley to the Marquess of Lansdowne.

Knowsley. 5 July.-Though the offer which I have received of a Lordship of the Treasury comes directly from Mr Canning, yet after the communication which I had with you upon the subject, and more particularly as considering you as the head of that part of the present Government to which I chiefly look, and to which I consider myself as attached, I venture to enclose to you a copy of a letter which I have sent to $\mathrm{M}^{\mathrm{r}}$ Canning by this day's post. I have, as I thought I ought to do, distinctly stated to him my views in accepting or declining-which it may be, rests with him. I hope you will not think I have taken too high a tone, but the real fact is that without some ulterior views I would very much rather not have, than have, a Lordship of the Treasury, and there may be many who may be far more anxious about it, and to whom I would very willingly resign it. At the same time, looking at it as a mere initiation into the routine of business, it may give me habit and practice which may be serviceable in higher situations hereafter. ...

(Bowood MSS.)

\section{James Abercromby to the Earl of Carlisle.}

Monday night.-I have had a long talk with $L^{d}$ Lansdowne \& he has consented to my stating to you the impressions left on my mind by what he has told me. He has a strong feeling that from the way in which he left off with Canning, your enforcing the admission of $\mathrm{L}^{\mathrm{d}}$ Holland to office will be most important. The first thing is with respect to the present formation of the Cabinet. 
What was originally proposed was a Cabinet of 12 , you being three. Now it is a Cabinet of 15, your numbers being without addition. In the common party view this would be an objection, but undoubtedly there is too much confidence \& mutual good understanding to rest even for a moment on that point. But the impression on adherents \& the public is not indifferent. Altho' these are truths they perhaps ought not to be dwelt upon, when the objection becomes far more strong, if it is to be maintained that the numbers of the existing Cabinet are a valid \& sufficient reason for not strengthening the Gov't in the quarter where it is the weakest. This is not a fair argument on Canning's part, for he has increased the Cabinet by the addition of some of his own friends, who carry no weight, \& who by swelling the number, become a source of weakness, by affording a reason for excluding Holland whose usefulness in the Lords would be so great. I quite agree with you in thinking that as the case stands in the Lords, the accession of $L^{d}$ Holland is quite essential. $L^{d}$ Lansdowne felt that there was a delicacy in his pressing that point. $\mathrm{L}^{\mathrm{d}}$ Grey is a cause of great difficulty \& I see no other remedy that can mitigate the evil but that of taking $L^{d}$ Holland. On very many grounds I should ardently wish to see $L^{d}$ Holl[and] in office but I must at the same time admit that I see strong objections-but they ought I believe to yield to the difficulties of the case. In addition to all this, Ld Lansdowne concludes, not from any direct expression, so much as from the tendency of Canning's views \& language, that he expects to be pressed by $L^{d}$ Wellesley, \& that his inclination is to prefer him to $\mathbf{L}^{\mathbf{d}}$ Holland. Surely this point ought to be guarded, $\&$ in good time. Then there are now four places in the Household to dispose of-they ought no doubt to be given in the way that is most likely to strengthen the Govt. But Canning ought at least to communicate with $\mathrm{L}^{d} \mathrm{~L}$. \& to consider in some degree his new allies. I do not know who want such things but I have heard Ld. Hereford \& $L^{d}$ Foley named. If Morley is to get the Post Office would $L^{d}$ Courtown's place do for Carnarvon ? I know that $L^{d}$ Lansdowne is in a degree pledged to assist him. What $I$ have said about the Household is all from myself, \& chiefly because I know that there are critics who will draw inferences, perhaps too large, from the way in which the Household troops are chosen. I have not been satisfied since I heard that both Sturges Bourne $\&$ the D. of Portland were to remain in the Cabinet. Not that I in the least object to either personally, but the appearance is bad 


\section{THE FORMATION OF CANNING'S MINISTRY}

both for Canning \& $L^{d}$ Lansdowne. It looks as if there was a jealousy which I hope $\&$ believe does not exist-it seems as if the one was grasping \& the other yielding. I should guess that the conversation went off passing well. $L^{d} \mathrm{~L}$. has some consciousness that he does not stand quite where he ought to be. I wish that he felt it enough to make him more resolute. For it is apparent, I think, that Canning is sufficiently disposed to act the master, as if all was his own, \& does not reflect on the fact that most of his support is only during pleasure \& good behaviour. In truth I see none of them who have an adequate notion of the independence $\&$ spirit that govern many of their new adherents. I am very anxious about your talk with Canning. I think that you may do a great deal of good, \& the occasion is critical.

(Castle Howard MSS.)

339. The Duke of Cumberland to the Duke of Wellington.

Berlin. 6 July. Private.-Accept my best thanks for your kind and most highly interesting communication, which I received last night. The very confidential manner in which you have explained to me all that has passed upon this melancholy occasion demands from me equally my views to be known to you, as you do me but justice when you say that you was convinced I should regret all that has taken place. I can most solemnly declare that I never felt any thing more deeply or ever suffered greater anxiety of mind than I do at the present moment, when I see my brother in the hands of such a man as $M^{r}$ Canning, who is the most ambitious, wrongheaded and violent man I have ever met with; my first political acquaintance with him commenced in 1806 at the time the Talents were in, \& we were in opposition ; from my being known to enjoy so fully the confidence of my late revered father I was the intermediate point between him and the then ex-Ministers $\&$ their friends. Of these $\mathbf{M}^{\mathbf{r}}$ Canning was then one and I had a full opportunity of learning his character. One can with truth apply to this statesman qu'il n'a ni foi, ni loix, all is equal to him, friend or foe, all he cares for or runs after is popularity of the moment, and to obtain that there is nothing he will not do. Remember only our conversation at Vienna in the year 22 when I said he never would rest till he was Prime Minister, \& I am certain had he not found in Lord Liverpool a man whom he could manage \& lead just as he thought proper, he would have never ceased till 


\section{THE FORMATION OF CANNING'S MINISTRY 25I}

he had got rid of him, \& in fact $\mathrm{M}^{\mathrm{r}}$ Canning has been in my opinion Prime Minister for the last three years without the name. To every one it has been evident that for the last three years he has been courting the Opposition, \& being aware of the declining state of health of Liverpool he had long been forming his plans of operation to secure to himself his present situation. The only two persons he dreaded in the Cabinet were yourself and our worthy \& respectable friend Eldon. How he managed it I cannot say, but it appears to me from all I can learn that neither you nor Eldon were permitted to see my brother for the last days till $\mathrm{M}^{\mathrm{r}} \mathrm{C}$. got all his own way, and here reigns a mystery which it appears no one can unravel. From the various speeches made in both Houses of Parliament upon the occasion, it is clear that $\mathrm{M}^{\mathrm{r}}$ Canning at last by the basest falsehood poisoned the mind of my brother by trying to impress on his mind that the ex-Ministers were caballing, \& to prove this, that he had only received their letters of resignation one and all as he entered H.M. closet. The falsehood of this has been pretty well proved in Parliament, and the Premier's character as a liar stands proclaimed not only throughout all England, but all Europe. Perhaps my dear Duke it may be of little avail or of little consequence to you to know what were my sentiments on the occasion, but having had the satisfaction of acting so many years with so many of your colleagues, I may be allowed to explain them. As soon as poor Liverpool's illness was known, it was evident to me that even if he recovered to a certain degree, his remaining in office was out of the question, \& I believe this was the general one. Every one speculated naturally on the occasion and all sorts of ideas were afloat on the person to be named in his place. I own I did not believe that $\mathrm{Mr}^{\mathrm{r}} \mathrm{C}$. would have been appointed, though I never doubted his ambitious views on the subject ; many there were however who prophesied it, and my reply was, if this does take place, then depend upon it that the D. of Wellington, Lords Eldon, Bathurst, Westmoreland, Bexley, and Peel will resign (I own I did not expect that Bexley could have disgraced himself as he has done) for it seemed to me impossible that you, all the great opposers of Catholic emancipation, could disgrace yourselves by serving in a Cabinet where the Premier was known to be the firm supporter of Catholic emancipation, and it was precisely for this said reason that I never could bring myself to believe that my brother would trust all the patronage of the Church in the hands of one who had constantly laboured to pull down that 


\section{THE FORMATION OF CANNING'S MINISTRY}

Church ; nay when I recollect the line of conduct Mr C. had pursued towards my brothers during the late Queen's trial, all this convinced me of the impossibility as I thought of his ultimately succeeding in his views. However, certainly H.M. has an undoubted right to nominate whom he chooses, but on the other hand it remains equally a right to those who were offered situations to judge for themselves whether or not they would accept, and I am fully of opinion that every one of you who resigned were not only fully justified in so doing for the reasons you have given, but that one and all must stand much higher in the opinion of the country. But you, my dear Duke, can not only be considered as a great public character in England, but as a great character in ALL EUROPE, and this is the general feeling here on the Continent; and as such your joining or not joining $\mathrm{Mr}$ Canning's Ministry was a very material point, for every Cabinet of Europe \& almost every Sovereign knows you personally, \& knows that every thing that you are concerned with is stamped with honour, whereas I need not tell you, that $M^{r}$ Canning has acted in [such] a manner that there is not the slightest confidence in anything he does or says. I am grieved as an Englishman to be forced to avow this, but alas it is too true \& the mischief this gentleman did the British Government last Dec ${ }^{x}$ by that ridiculous and absurd speech he made in Parliament respecting Portugal, is not to be calculated, but easily conceived, \& you may rest assured as long as he is at the head of the British councils, there will be little or no confidence placed in them. That your conduct has been duly appreciated here I need not tell you, and I can assure you that from HIGHEST to lowest there is but one prayer that the time may soon arrive when you are at the head of the Government.

No one can lament more than I do the situation of my poor brother; what must be his feelings when he sees his Government solely almost supported by those very men who for the last 20 years have been trying to dethrone his late father \& overturn the Monarchy. Radicals, democrats never can change their principles, nay they tell you plainly "we have not changed our principles, but Mr Canning has come round to ours; so that we can call the present Ministry a Radical one." Excuse this long letter, but after the very confidential manner in which you have written to me I have deemed myself in duty bound to explain my feelings. There remains still one salvo \& that is that our friends be united and without being factious yet not allow themselves to be led into apathy. 


\section{THE FORMATION OF CANNING'S MINISTRY 253}

PS. I need not say after all this, that was I in England I should feel myself with the above sentiments bound to oppose $M^{r}$ Canning's Ministry, looking upon it a duty I owe the King, the country \& my own public character for consistency.

(Wellington MSS.)

\section{Charles Arbuthnot to Robert Peel.}

Whitehall Place. 6 July. Private.-Everything seems to be much in the same state-as to outward appearances-as when you left London; and with respect to any fixed and settled form of Government, there is not I believe much more to be told than was the case three months ago. I understand that the not knowing what to do with Lord Lansdowne is at this moment Canning's main difficulty. A short time ago I was, as you may remember, told by Herries that Lord Lansdowne was positively to go to the Home Dept, and that Canning was endeavouring to persuade Sturges Bourne to remain in the Cabinet with the Woods and Forests, Lord Carlisle being destined for the Privy Seal. But yesterday I heard from Holmes that the King $\mathrm{w}^{\mathrm{d}}$ not consent to have $L^{d}$ Lansdowne and Spring Rice at the Home Department ; and that the idea now was that $\mathrm{L}^{d}$ Lansdowne shd have the Foreign Office, Sturges Bourne having been prevailed upon to remain where he is. Holmes added, however, that Lord Lansdowne insisted' upon the Home Office, and that Canning was sadly embarrassed, not knowing how to act. I am inclined to believe that Canning's embarrassments are such as I have here stated. It is certain that between him and the Whigs there is not as yet the slightest amalgamation, and I have heard both from Holmes and from Herries that the exactions of the Whigs, and their attempts to encroach, drive Canning nearly out of his senses. He said very recently that the Whigs had better beware-that he was clinging to the tree (i.e. the King)-but that they were only hanging to his feet. Holmes was with me nearly two hours yesterday. He said much to convince me that the Government is in the most unsettled state, and I believe him to be sincere in his declarations that without a miracle the whole will break to pieces long before the next Session. He told me that the Whigs up to the very last day $w^{d}$ not consent to receive Treasury notes, and that they never would attend unless they were summoned by Lord Duncannon.

I believe I told you that Herries had not actually resigned. He 


\section{THE FORMATION OF CANNING'S MINISTRY}

seemed resolved not to remain where he is. I did not ascertain whether he thinks of retiring altogether, or whether he is looking to a Privy Counsellor's place. There is no harm in his keeping his present situation, but it will be quite another thing if he avails himself of this crisis to obtain an advance; and impressed as he is with the instability of the Government, it wd be absurd to commit himself with a Party of which he thinks as ill as we do. But this is a question $w^{\text {ch }}$ he must decide for himself. He tells me that Canning and the Whigs are as wide asunder as pole is from pole, that Canning's time is passed in resisting their encroachments, that of these encroachments even Huskisson now complains bitterly, that Planta is in despair, and that in short the two Parties are so at variance that sooner or later they must split and break to pieces. Such is Herries's language ; and as you will observe, it is exactly conformable to what I have heard from Holmes. The worst thing for Canning is that he is changeable as the wind that blows. Of course he hates the seceders ; but just at this moment he has not time to think of them, the whole wrath of his soul being directed against Lord Grey. I forget whether I told you that for an instant he had resolved to take a peerage, that he might meet Lord Grey in the Lords, and there combat him. I could add much more, but it $\mathrm{w}^{\mathrm{d}}$ be all to the same purport.

$I$ believe it is now positively settled that Lord Anglesey is to go to Ireland. Ld Wellesley, however, is to stay there till Xmas, it having been his earnest intreaty (on account of his money affairs) that he may be left where he is half a year longer, and before that time has elapsed Canning may have come to the determination of abolishing the Lord Lieutenancy. This has certainly been one of his recent projects. He flew into a passion upon hearing that Spring Rice, the Duke of Leinster, and others were scheming to. have no more $L^{d}$ Lieutenants; and he told Herries that he w $^{d}$ send for them and let them know that they shd follow his measuresnot he theirs. The meeting took place. They were not convinced by Canning, but he was nearly so by them. For a day or two his. notion was that the Lord Lieutenancy must be done away with. Whatever may be his difficulties-whether they are to destroy him, or he to surmount them-there is not, you may be assured, a man who does not feel that he has not a grain of common judgment. Planta is more impressed with this than anyone. I had occasion to see him yesterday upon some Treasury business relating to Lord Liverpool, and in the course of conversation he burst 


\section{THE FORMATION OF CANNING'S MINISTRY 255}

forth and exclaimed, "My dear $\mathrm{M}^{\mathbf{r}}$ Arbuthnot, who will ever be able to give judgment to $\mathrm{M}^{\mathrm{r}}$ Canning ? He will take the advice of one person today, of another tomorrow, and on the next day of a third."

But I must draw to an end. Of the King I know nothing except that he will not see the Whigs, and that he hates them (as I am told) as much as ever.

[PS.] Huskisson is seriously ill. George Harrison and Hart Davis are Knighton's great friends. They declare to Holmes that the Govt cannot possibly last. $\mathbf{L}^{\mathbf{d}} \mathrm{W}^{\mathrm{m}}$ Bentinck is to go to India. This I believe is certain.

The Duke of Dorset has been asked to Windsor by the King and goes on Monday. ${ }^{1}$

(Add. MS. 40340, ff. 156-9.)

\section{William Lamb to the Marquess of Lansdowne.}

Phoenix Park. 9 July.-I got here on Saturday and found Lord Wellesley in good health and spirits. He expressed great satisfaction at hearing of your coming to the Home Office, which I hope has taken place by this time. Yesterday I saw the Chancellor, who received me with the greatest kindness. He expressed himself very anxious to get away as soon as possible, said that he felt the awkwardness of his situation; that he was thwarting the Government and delaying the appointment of the Solicitor General ; that he knew it to be his duty, whilst he remained in office, to forward the objects of the Ministry, instead of embarrassing them, that perhaps he had taken up the matter too warmly, but that he felt so strongly upon the subject, that he could not reconcile it to his sense of duty to act otherwise. It is evident to me that he feels he has gone too far, but it is now too late for him to retreat. He is too deeply pledged upon the point. Doherty is naturally annoyed and feels it as tether (?) upon his appointment, but this is now without remedy. ...

(Bowood MSS.)

\section{William Lamb to George Canning.}

Dublin. II July.-Understanding that the Chancellor has inclined to give way about the Solicitor General, I took the oppor-

1 A portion of this letter is printed, very inaccurately and with many unspecified omissions, in Parker's Peel, i. 49I-2. 


\section{THE FORMATION OF CANNING'S MINISTRY}

tunity of seeing him again this morning upon the subject, when he told me that he certainly had felt very strongly that he had thought it his duty to make the stand for the sake of the Bar, but that as he had failed in altering your determination upon the subject, he knew it to be absurd obstinacy to persevere, and that therefore he was ready to seal the patent, whenever it might arrive. . . . (Harewood MSS.)

\section{Joseph Planta to Stratford Canning.}

II July. ${ }^{1}$ Private.- . . The arrangements which are to complete the Cabinet in the state in which it is intended to remain are now finally decided with the King, and will be declared in a very few days. The Duke of Portland will resign the Privy Seal, keeping his place in the Cabinet. Lord Carlisle will take the Privy Seal, and Mr Sturges Bourne will take the Woods and Forests in his place; and Lord Lansdowne will take the Home Dept, appointing Spring Rice his Under Secy of State. Lord Anglesey is destined in due time to succeed Lord Wellesley in Ireland. Lord $\mathrm{W}^{\mathrm{m}}$ Bentinck goes to India, and who is to succeed Lord Anglesey in the Ordnance or in the office of Commr in Chief I do not know. Much talk is, of Sir George Murray for some situation in England, but whether in the Ordnance or in the office of the Commr in Chief, I do not know. The army must shortly be put into the hands of somebody, and as it seems now, I regret to say, day after day more improbable that the Duke of Wellington will return to it, the talents of Sir John [sic] Murray will become the more necessary in that branch. Lord Dudley will remain at the Foreign Office. He takes to it very well, and seems to like it. Backhouse has succeeded me in the Under Sec[retar]yship and performs the duties thereof very successfully. In all questions of arrangements I have not failed to bring your name before our chief, and his view seems always to be that, after you have completed what you have to do on this most difficult and arduous subject of Greece, you should return home; and that he should then find employment for you here, as we had always intended.

Our difficulties will be very great indeed next Session, more particularly in the House of Lords, in which assembly we have as yet been able to make very little progress. In the Commons we are strong-by the means of those that have joined us-but

1 The letter was begun on the roth; this portion was written on the rrth: 


\section{THE FORMATION OF CANNING'S MINISTRY 257}

then how will they act-and will they not give us constant trouble? In short, to say that our prospects are clear and satisfactory is impossible; but if your cousin does but keep his health (of which there is every chance, for he is delightfully well now) I think he will in the end triumph over all opposition . . .

[PS.] Your cousin's health has been supported in a most extry manner through all his trials, and tho' he is fagged and pulled, he is really very well.

$$
\text { (P.R.O., F.O. 352/16.) }
$$

\section{Edward Ellice to J. G. Lambton.}

II July.-I beg you to understand I am no malignant, or ill-wisher to the Government, and had I been in the House of Commons I would have followed Lord Althorp. But it is expressly because I am a well-wisher of a liberal order of things that I deplore and lament the excessive folly, which led to what was called the political arrangement between $\mathrm{M}^{\mathrm{r}}$ Canning and Lord Lansdowne, and the indirect proceedings towards Lord Grey. If his advice had been followed, the Whigs must have been admitted to office on equal terms with $\mathrm{M}^{\mathrm{r}}$ Canning, and would have been entitled to equal power and an equal voice in the Cabinet; and the present, and increasing difficulties of the Ministry, are the natural consequence of the jealousy on both sides, which the original inequality, and the perpetual endeavour to reduce it, must create. To satisfy the alarms of Lord Goderich, Vansittart !! and their party, the schism must be kept up with Lord Grey, and Canning, of all other persons interested, is the least indebted, to the weakness of Lord Lansdowne, and the intrigues of his two assessors Bruffam and Tattier (?). Then, if it was not that I sincerely deplore the consequences on every account, the whole click may get what they justly deserve for their conduct to Lord Grey. Canning and the King had made up their minds (and this was also some security to Lord Goderich) as to his exclusion from any arrangement. His friends (as they call themselves) fully aware of this, and anxious for any excuse to throw him overboard, instead of openly stating the fact (which they must have known) to him, and which if so communicated, would have had no influence in deciding his opinion, or support of any creditable arrangement, resorted to every indirect expedient, of inattention, neglect, and studied distance of manner in their communications with him, to provoke what they desired, a dis- 


\section{THE FORMATION OF CANNING'S MINISTRY}

claimer on his part of any participation in the negotiation. But the whole affair has been one of intrigue from beginning to end, and $\mathrm{M}^{\mathrm{x}}$ Canning only professes to be able to carry on his Government for any useful purpose, on the same principle. But will he be able? I wish I could hope so. . . .

A Lord of the Treasury-one Whig out of four-is no great matter . . . Lord Lansdowne and Spring Rice will be something to the purpose- and then, when Bruffam gets into office, to be sure, it will savour much of the annihilation of many useless elements in the Cabinet, but not a great deal of any better union among the remainder. If he leaves his profession, to take political office unconnected with it, he will ruin himself and do mischief to his friends. Canning and he would not live a month in the same Cabinet. But what strength, except that of his voice in the House of Commons, would he give to any Administration? And how much opposition and jealousy ( $\mathrm{I}$ mean in any other department than the law) will he not provoke? In short, I despair of much good until all the Whigs get together, and the liberal Tories are disposed to support them as a Party. And the ultra Press, and the utter incapacity of the old Tories to produce instruments and means of carrying on a bigotted and besotted Government, are the best chances we have of such a state of things.

(Lambton MSS.)

\section{Sir Charles Bagot to the Duke of Wellington.}

Brussels. I3 July.-Private.-The mail which arrived this morning from England has brought me letters which state, upon an authority which I can not question, that $\mathrm{M}^{\mathbf{r}}$ Arbuthnot has advised himself to represent to you that, upon my being questioned by a Foreign Minister at this Court as to the meaning of your resignation of your office, I had replied, " Oh ce n'est rien, excepté que le Roi d'Angleterre s'est enfin debarrassé d'un joug aristocratique qui avait pèsé sur lui depuis trop long tems." Mr Arbuthnot's motives in making this representation are sufficiently obvious. My motive in writing to you this letter is to state that the allegation is false. $\mathrm{M}^{\mathbf{r}}$ Arbuthnot's opinions respecting me are in all cases a matter of absolute indifference. In 999 cases out of a I,000 his representations of what I may say, think, or do, are equally so. But it is not indifferent that even he should make a representation to you which is not founded in fact, and of which 


\section{THE FORMATION OF CANNING'S MINISTRY 259}

the tendency is to impress you with the idea that I have held language in respect to you which is inconsistent with those sentiments of sincere gratitude, private attachment \& great public respect and admiration which I ever have, and ever must bear towards you. It is equally due to you and to myself to assure you that I have never used any language upon the subject of your resignation, or indeed of that of any of the Ministers of the Crown who resigned their offices at the same time that you did, which could by the most artful or by the most malignant construction be made to bear that sense which is implied by the words which I am represented to have used. My opinions upon questions of home politics can be of no consequence to any man-nor should I presume to mention them to you but as they become incidentally necessary to repell an unjust imputation. I always thought, and I still think that the resignations which took place in the Administration were unnecessary, and attended with great public inconvenience. I am perfectly satisfied that the motives of those resignations were perfectly honorable and conscientious. That in the struggle consequent upon the real or supposed impossibility of keeping together the old Government, my old friend and master who first brought me into public life, to whom I am bound by every tie of esteem, regard and obligation, whose talents I admire, and whose principles I respect, should have succeeded to the Government of the country was a matter of great and natural joy to me; but that I have ever testified that joy by the expression of any sentiment of the nature of that imputed to me by $\mathrm{Mr}^{\mathrm{r}}$ Arbuthnot is not true. It is only to yourself that I shd think it worth my while to make any such declaration-but it would give me very sincere pain if I thought that by such misrepresentations you should be led to doubt of the integrity of my personal feelings towards yourself.

(Wellington MSS.)

\section{Viscount Milton to the Marquess of Lansdowne.}

Wentworth. I3 July.-... I write to you rather than to any other of the Whig Ministers, because in the first place I can speak more familiarly to you, but principally because I must take leave to consider you as the most responsible person, indeed I may say the only responsible person. Indeed this responsibility is no light matter, but you know that I think you did right in undertaking 


\section{THE FORMATION OF CANNING'S MINISTRY}

it ; nay more, that you would not have been justified in shrinking from it. Those, however, who have been so long engaged in the same course of politics with you, will, if I can judge of others from myself, have heavy demands upon you, and unless those demands are fairly complied with, I very much doubt whether the Administration, as now constituted, can continue. In order to counterbalance the hatred and pertinacious activity of the Tories, who hate all the Ministers equally, Canning quite as much as you, you must excite and draw into corresponding activity the zeal of those who, during the last Session, have formed the only efficient support of Government in the House of Commons, and you may be assured that this will be impossible, unless they see a determination, not consisting in words but in acts, to carry into effect the measures which they have so much at heart. On the Catholic question I have little to urge because there are abundance of persons who will be ready enough to agree with me and to express that agreement, in opinion that, unless it is to be brought forward as a Cabinet measure, none of you can remain in Administration. Indeed, you will be far better out than in. With the old King many a man might most honourably show a deference to his strange but, I believe, conscientious prejudice-but under the present man we all know full well that if he is as much opposed to the Catholics as your predecessors have insinuated, that opposition is founded upon anything rather than a conscientious feeling-he has said and done things in the course of his life, which entirely disable him from taking credit for feelings on the subject, which can entitle him to the slightest deference. It may however, be said that a Cabinet the members of which are individually favourable to the Catholic question is more likely to promote its ultimate success (even though their hands are tied for the present) than one of a different complexion. This I know may be said, but I confess that it does not weigh much with me; but on the contrary I am strongly of opinion that, if the Government is to act either neutrally or adversely, it will be far better that that neutrality or adversity should be attributable to the opinions of the Ministers themselves than to those of the King; and as the Cabinet is now composed, its hostility or even neutrality could only be ascribed to the King, which, as far as I can see, would be the most unfavourable state in which the question could be placed. It of course follows from this that you had better be all out of office than remain in upon these terms. You will now accuse me in all 


\section{THE FORMATION OF CANNING'S MINISTRY 26I}

probability of having broken my promise about the Catholic question, but you have still something to undergo on the subject of economy, upon which I am the more earnest because it has appeared to me that there has been a certain relaxation of earnestness among our friends for the last three or four Sessions, and I think I have seen enough to know that this relaxation, of which I complain, is more likely to increase than diminish, now that they are so near the threshold of the Treasury. But whatever may be the feeling among persons in that sphere of life in which the difference between the north and the south wall is more sensibly felt, I think I can venture to say that with the people at large, there will be no difference whatever. Their demands for economy never sprung from anything like party feeling-from no preference for the Party out of power to the Party in power, from no idea that motions for retrenchment might be made an engine for turning out an Administration. On the contrary, the greatest clamour has upon many occasions proceeded from persons who not only were, but proclaimed themselves the supporters of the last Administration-the Gooches, the Fellowes-hoc genus omne, were as noisy at County meetings (whatever they might have been at the back of the Treasury bench) as the most speculative reformersnor was it to be wondered at, for, in spite of $\mathbf{M r}^{\mathbf{r}}$ Webb Hall, they had sense enough to perceive that in proportion as their tenants paid more to the tax gatherers, they paid less to the landlord. But if these demands for economy proceeded, not from any party feeling or party views, but from a wide spreading and well founded opinion that enormous taxation is the great evil that weighs down the resources of the country, it becomes infinitely more necessary, not only for the good of the country but for the stability of the Administration, that some great and visible steps should be taken to abate this evil. That the good of the country requires it is obvious to any man who will give himself the trouble to think. What other cause can be assigned for the distresses we have experienced since the return of peace, or at least for the difficulty with which we have extricated ourselves from difficulties, partly perhaps originating in other causes? I need not however pursue this any further because I believe we are perfectly agreed upon the question, and my object in writing to you is not so much to inculcate opinions, which would be very absurd, when you are so much better qualified to give than to receive, as to urge you and through you the Government, to take measures which will be palpable and effective-and 


\section{THE FORMATION OF CANNING'S MINISTRY}

this is not to be done by cutting off a clerk here or a secretary there, or by reducing this or that salary. Whole establishments must be cut down and abandoned, and there are many such, the loss of which would neither impair our tranquillity at home or our strength abroad. Whatever is done must be done on a large scaleit must be done without regard to old or new friends; you must brace yourself against the importunities of various classes, some who ask shamelessly for themselves, some who pretend, some who fancy they plead for the country, some who from long habit, not from any improper motive, have imbibed the opinion that what has so long existed cannot be dispensed with-and all agreeing in determination to thwart the reformer in every possible manner. I press these matters the more because I wish to be able to support the Government to a greater extent than I have yet done, and I believe this is the feeling of a great number of persons; but this wish cannot be gratified till we see what fruits the tree bears. To go into details is not my business, but I must remind you that, when we are told it is the Debt which oppresses us, and that no reductions in the expense of government can be sensibly felt, I must, I say, remind you that, while the Debt has not been trebled, the expenses of government have been more than quadrupled since I792, and this, without reckoning the half pay. These are circumstances which, to unofficial persons like myself, are inexplicable, but, though inexplicable, they afford me great hope, for I am satisfied that all the legitimate objects for which Governments of all kinds exist can be attained at a far less cost-but it will require great firmness and energy to effect it.

Having now written what I suppose a Minister will consider as approaching to a scold, I must express my gratification at the Treaty about Greece. I hope it was not a legacy from your predecessors but that you are entitled to all the credit of it.

(Bowood MSS.)

\section{J. C. Herries to Robert Herries.}

Montreal. I6 July.-I have been completely knocked up by the fatigues which the peculiar circumstances of the late session heaped upon me-aided, no doubt, by the discomfort which those same circumstances created. I was not only weary but sick of all that was going on, \& vexed, moreover, that I was unable without dealing unfairly by the public service, to withdraw myself from 


\section{THE FORMATION OF CANNING'S MINISTRY 263}

the mess. The consequence has been exhaustion and illness such as I have not experienced for many years, if at all. I have been laid up more or less this fortnight. I am now getting better but I find that a long interval of relaxation is indispensably necessary for my complete restoration. Under these circumstances I have given warning to Canning that I cannot face the double work of my present station, that of both directing \& executing the affairs of the Treasury. He wants me to take some other situation in which I may have more honor \& more ease, so as to be able to assist him in finance $\&$ in Parliament. I have discouraged these propositions, but I have assured him that I will endeavour as much as possible to meet his convenience in the mode \& time of my ultimately giving up my present office. . . .

(Herries MSS.)

\section{Earl Bathurst to Charles Arbuthnot.}

Cirencester. I7 July. Private \& confidential.-I am much obliged to you for your letter. It is so essential to get the Duke of Wellington to accept the command of the army that I am not surprised at any attempt being made to accomplish that object. The good of the army is the plea; but that is not felt either by the King or $M^{r}$ Canning. His Majesty you may be sure thinks he is governing the army admirably well ; \& tho' he may sometimes perhaps be a little annoyed by the accumulation of business, or Lord Palmerston's objections, he is in his own mind satisfied that he is as good a Commander-in-Chief as the Duke of Wellington-indeed as a cavalry officer, he is quite sure that he has the advantage over the Duke. And as for $\mathrm{M}^{\mathrm{r}}$ Canning, the army is not the arm which he intends to use in his military operations to carry into effect his projects, whatever they may be. But both he \& the King know that by getting the Duke to accept the command, altho' in doing so the Duke would wish it to be understood it to be no political junction, it would have all the effect of being one. The friends of the Ministry would so represent it, \& they who wish to return would so consider it, \& shape their course accordingly, while the Duke could hardly be churlish enough to deny it, \& to reject the many flattering advances which every member of the Administration would upon system publicly make towards him. There can be no doubt therefore that his acceptance would entirely break up the party: but it would not be just by the Duke to call upon him 


\section{THE FORMATION OF CANNING'S MINISTRY}

to make a sacrifice of his high military station for the purposes of party ; and it must therefore rest with him what to do, or to speak more correctly, on what principle he is to act.

The case appears to me to be somewhat different now from what it was when the former offer was made. Lord Lansdowne is now the Home Secretary, with the Irish Government under his control, and (back'd as he is by powerful \& active adherents) with no inconsiderable political influence in this country. Is it the same thing for the Duke to accept the command now, as it would have been had he accepted it when the system had not been brought to this maturity? I speak very hesitatingly as you will see upon the conduct which the Duke ought to hold, \& I should be very ill prepared to give advice as there are many $\&$ many reasons which ought to influence the Duke in not rejecting an offer, which on public principles, \& out of regard to the profession to which he belongs, he should accept. But I have no manner of doubt in saying that the Duke did quite right in declining to go to Lord Mareborough's [sic] on such an intimation. There is not the smallest doubt that it would have been misrepresented, \& in rejecting it, he was also quite right in expressing himself very strongly with regard to the King, as he ought always to profess great personal attachment to his Majesty.

Knighton is such an old rogue that there is no knowing what to collect from his manner of talking of the crew. But I am quite sure that the King must by this time regret the appointment of the Duke of Clarence. The appointment of the heir presumptive to the head of the army or navy is a hazardous measure, \& requires great good sense \& good temper too, in both parties, to make it answer. I doubt whether the old King would, with all his partiality for the Duke of York, have appointed him to the command of the army, had the Duke been his heir apparent or presumptive; nor was he so, when the present King, as Regent, recalled him to the command, nor could it have gone on well, when the Duke became heir presumptive, except from the entire loyalty \& devotion which the Duke bore to the King, who was as much attach'd to him, as he can be to anybody; and yet even with all that known devotion on one side \& brotherly friendship on the other, there were always jealousies whenever the Duke appear'd to be popular. What then must be the feelings of the King to see such an heir presumptive as the Duke of Clarence, popular at the head of a popular profession with which his Majesty is no other- 


\section{THE FORMATION OF CANNING'S MINISTRY 265}

wise conversant than what he may have collected from his dayly voyages up \& down the Virginia Water. I had almost forgot however the long voyage the King took to enable Sir Edmund Nagle to win his bett of Lord Hertford.

Lady Verulam's account to me of the Jenkinson cabal very much corresponds with that which Cecil Jenkinson has given to you. It is fortunate that Cecil is not a Canningite, otherwise we should have more "too bads" publish'd to the world." Bishop Jenkinson professes to be a loser by the Deanery of Durham. . . .

[PS. by Lady Georgiana Bathurst.]

To think dear Mr Arbuthnot we should live to see the Duke of Wellington paying his respects to $\mathrm{L}^{\mathrm{d}}$ Palmerston. I think $\mathrm{L}^{\mathrm{d}} \mathrm{P}$. if he has any feeling must have been ready to drop when he saw the Duke enter-but he was quite right to go on.

(Arbuthnot MSS.)

\section{Viscount Melville to Charles Arbuthnot.}

Melville Castle, Edinburgh. I9 July. Private.-Many thanks for your communication of the $15^{\text {th }}$ inst. which I received today. It exhibits a curious picture of the state of affairs, \& I should suppose that the principal performers are in a very uncomfortable predicament-as might be expected \& was foreseen. In this part of the world I think the general feeling is decidedly with us, more so indeed than I had anticipated. Almost all the great leading interests are on our side, \& if the Government will only perform, as I have no doubt they will, \& as they did in $\mathrm{I} 806$, a few Whig pranks in this country, it will settle matters as satisfactorily as possible.

From Sir Walter Scott's conversation he is entirely with us. I do not know as to Lockhart, but I met in a public company a few days ago a great ally of his, Professor Wilson, who seemed to be strongly with us; I beleive he is Blackwood's chief supporter.

The Duke of Gordon called here yesterday. He gave me an account of his visit to Windsor \& other matters, \& seems to be very decided in his political notions.

1 Lord Londonderry had written to Planta, then Under-Secretary of State for Foreign Affairs, applying for a pension. Lord Liverpool, to whom Canning transmitted the application, endorsed it, in pencil, "This is too bad "; and the remark was communicated to The Times by someone at the Foreign Office. Two of the letters were quoted by Londonderry in the House of Lords on 26 June I827. See p. 28r. 


\section{THE FORMATION OF CANNING'S MINISTRY}

Canning has recently, \& in an unhandsome manner, disobliged greatly the Buccleuch family, unwittingly I suspect in the first instance. Lord Arbuthnot[t] tells me that Canning had since desired to see the young Duke (who will be of age in November) $\&$ that the interview ended very drily on the part of the latter. Canning will now be placed in a fresh dilemma in the same quarter by the death of Lord Morton, who held the Lieutenancy of this County (Edinburgh) with the declared intention, when he was appointed, of resigning it to the young Duke when the latter came of age. I have thought it right to explain distinctly to Canning all that has passed in regard to that appointment since the late Duke's death in I8I9, \& I have sent Lord Montagu a copy of my letter. Canning therefore will not be allowed to plead ignorance of the intended arrangement, \& he must either do what I have no doubt will be very disagreeable to himself, viz. put the office in commission for a few months with a view of giving it to the Duke in November, who will not support his Government, or else give it to Lord Rosebery, who though he has a considerable property in the County, does not reside in it, \& whose nomination to that particular situation, to the prejudice of the Duke, would raise a great outcry here. Lords Lothian, Morton, Dalhousie, \& a Lord Torphichen, are, besides myself, the only other resident peers in the county or at least who have their chief residences in it. The new Lord Morton is brother in law to Lord Aberdeen, \& son in law to Sir George Rose, \& held a diplomatic situation at Berlin.

The Corporation of Edinburgh seem inclined to be troublesome, but as yet there has been no overt act, \& I am told that they will remain steady. I am also told that my son would displace Sir G. Clerk in the county without any difficulty, but any scheme of that kind had better not be whispered at present. There certainly is a strong feeling here against Sir George. . . .1

(Arbuthnot MSS.)

1 Lord Carlisle wrote to Canning on 23 July : " In case you like to offer the Green Ribband to the Duke of Buccleugh, I merely mention that my father received it before he was of age." "I think enough will be done for the Duke of Buccleugh without it," replied Canning next day. (Harewood MSS.) Melville wrote again to Arbuthnot on I9 August : " . . . Canning wrote to me that under the circumstances mentioned in my letter to him as to the Lieutenancy of this county (Edinburgh) he should have no hesitation in advising the King to appoint the Duke of Buccleugh when he attained the proper age." (Arbuthnot MSS.) 
350. The Marquess of Lansdowne to George Canning.

Saturday afternoon. 2I July.-I think it right not to delay till we meet mentioning to you that I have just heard from Lord Carnarvon (who being on a tour in Scotland had not received my letter till many days after it was written) and that he declines the office you authorized me to propose to him. It is needless to trouble you with his reasons. . . May I beg however that you will not take any step towards filling up the Captainship of the Gentlemen Pensioners till I have had an opportunity of conversing with you, as I have a suggestion to offer on that subject which I am sure you will think deserving of consideration?

(Harewood MSS.)

\section{5x. John Doherty to George Canning.}

Stephens Green, Dublin. 2I July.-I hope and trust that you have not for a moment attributed to any want of the warmest feeling of gratitude my not having ere this returned you my most cordial thanks. I assure you I have imposed a very great restraint on myself in refraining during the length of time I have been aware of your kind intentions towards me from an expression of my most grateful acknowledgements. . . . Lord Manners has this day sworn me into office, after having excited a general impression among the Bar and (I may add) the public here, that his conduct in interposing the delay, has been as dunwarrantable as childish. ... To relieve your mind from an apprehension that my promotion is extraordinary and without a precedent on account of my alleged juniority, I shall only observe that of the last eight persons who have held the office of Solicitor General in Ireland, but one was of as long standing (you will readily believe that I mean) at the Bar as I am. None of the others had been more than twelve years at the Bar whereas I have now been for twenty years in my profession. . . .

(Harewood MSS.)

\section{George Canning to Henry Brougham.}

Chiswick. Sunday, 22 July.-I was exceedingly vexed that my illtimed indisposition prevented me from proposing a time for the 


\section{THE FORMATION OF CANNING'S MINISTRY}

pleasure of seeing you last week. Would it suit your convenience to call in Downing Street in the course of next Wednesday morning? If so, I will be there at any hour that you will be so good as to name.

(Harewood MSS.)

\section{George Canning to J. W. Croker.}

Chiswick. 22 July. Private. - I am not in the habit of putting faith in anonymous letters. If I were, I should have no room for any other faith-for every day brings me a warning against some one whom I am supposed to trust. Where a letter, anonymous itself, contains no reference to real names, I consider it as absolutely false \& mischievous, \& nothing more. Where names are mentioned, the matter may be worth inquiry. Do you happen to know of the existence of a man of the name of Maginn soidisant $\mathrm{D}^{\mathrm{r}}$ Maginn? If your answer is negative, there is an end of the matter. If affirmative I will send you the letter ${ }^{1}$ that causes this inquiry.

(Croker MSS.)

\section{Lord Lyndhurst to George Canning.}

George Street. Monday [23 July]. - I have been very much vexed at your illness, and the more so as I fear I was in some measure the occasion of it. ${ }^{2}$ I shall have great pleasure in meeting you (and I hope quite recovered) on Wednesday. I will be with

1 " As it is only right that you should know your friends and your enemies, I beg leave to inform you that much of the slander in prose and verse against your Administration which fills the Standard and other London newspapers is written by an unprincipled Irishman named MAGINN, who styles himself Doctor, who is the protege and friend of $\mathrm{M}^{\mathrm{r}}$ John Wilson Croker.* Doctor $\mathrm{M}$. is also at the bottom of all the abuse poured out against you in Blackwood. I shall not give in my name but these facts are known to a certain circle and can be ascertained without difficulty.-I am, Sir, a Friend." (Copy.)

* [Croker's endorsement]: "I hardly knew him \& had no kind of intercourse with him. He was however a regular Doctor of Laws \& a very clever fellow-tho' not very orderly in his way of life." (Croker MSS.)

${ }^{2}$ Canning caught cold again through sitting in a draught whilst dining with the Lord Chancellor at Wimbledon. 


\section{THE FORMATION OF CANNING'S MINISTRY 269}

you soon after 2 and shall wait with impatience and curiosity the result of your conference with $B$ [rougham]. ${ }^{1}$

(Harewood MSS.)

\section{George Canning to Lord Lyndhurst.}

Chiswick. $24 J u l y$.-I have no answer from B[rougham], and as I gave him his choice of the whole day, he may choose an hour so late as to prevent my return here to a six o'clock dinner. Will you therefore instead of taking this place in your way tomorrow, meet me at dinner at Clanricarde's ? Considering your dinner here, however, only as postponed to a fitter opportunity ?

PS. Here is the end of the Doherty demurrer.

(Harewood MSS.)

\section{George Canning to John Doherty.}

Chiswick. $24 J u l y$.-You judged very rightly in not seeking any communication with me, during the interval of your abeyance. But you are happily mistaken in supposing that $I$ have had much trouble, on your account, from other quarters. To the unexpected objection which was opposed to your appointment, I caused it to be answered simply that I saw no force in it, and that I was contented to wait, and I never heard more of it till William Lamb announced to me its removal. There were not wanting indeed some of both persuasions, who would have been glad to stir up a controversy. But my impassibility, I flatter myself, spoiled that game : the oftener such hopes of conflict are in a similar manner disappointed, the better. (Harewood MSS.)

\section{Henry Hobhouse's Diary.}

$25 J u l y$. - A good deal of speculation has arisen from a visit paid by the Duke of Wellington on the $\mathrm{I}^{\text {th }}$ to the King at Windsor. The King had asked $L^{d}$ Maryborough why the Duke did not come to see him. $L^{d}$ M. said he was sure the Duke $w^{d}$ be most ready to obey H.M.'s commands, but without them he conceived his Grace wod

1 Brougham was now offered the $£ 7,000$ a year post of Chief Baron of the Court of Exchequer, in succession to Sir William Alexander. See Nos. 355, 358, 364. 


\section{THE FORMATION OF CANNING'S MINISTRY}

consider it presumptuous to approach the Royal Lodge. L $^{\mathrm{d}} \mathrm{M}$. communicated this conversation to his brother, who wrote an answer fit to be shewn to the King, expressing his readiness to pay his respects to the King, if he would signify his pleasure to that effect thro' $L^{d}$ Conyngham, or any other of his Household servants. Upon this letter being shewn to H.M. by $L^{d} M$., the King directed him to go to Stratfieldsay[e] and bring the Duke over. The Duke lost no time in repairing to Windsor, where he heard the King's story, and had an opportunity, $\mathrm{w}^{\text {ch }}$ he wanted, of telling his own in return. The King in a letter to $\mathrm{Mr}^{\mathrm{r}}$ Canning represented the visit to be a voluntary one on the part of the Duke, for the purpose of paying his respects on the anniversary of the Coronation, $w^{c h}$ day it happened to be, tho' that circumstance was unknown to the $\mathrm{D}$. of Well[ingto]n. The Ministers treat the visit as a matter of no moment, while the army look upon it as a prelude to the Duke's return to the Horse Guards.

Not a word is now said about the removal of $L^{d}$ Dudley from the Foreign Office. It certainly was Canning's intention to return to that office himself and to keep with it the First Lordship of the Treasury, but whether he has laid aside that design, or only postpones its execution, or reserves the office for some further compromise with the Whigs, who are pushing for everything that falls, or has persuaded Ld Dudley to stay against his will (for no one doubts that he is averse from the constraint of an official life) lest his departure shod open a door for Whiggish importunity, appears quite uncertain. (Hadspen House MSS.)

\section{Lord Lyndhurst to George Canning.}

Thursday [26 July]. - I have this moment returned from my Court. $\mathrm{B}$ [rougham] came to me there. He was very smooth and good humoured but declined the offer. It (the appointment) might put him in the road, he said, to everything, but it would leave him without horses to pack on. The House of Commons was his only instrument and he could not part with it. In an affair of this nature he consulted only his own interest and this was the view he took of it. He wished it to be understood that he did not refuse the offer from any disinclination to the present Government ; on the contrary, he approved of their measures and of the persons who composed it, highly. This he repeated several times, but, he said, he must not be disarmed. He was not a Whig-he had never been of that 


\section{THE FORMATION OF CANNING'S MINISTRY 27 I}

Party !! He considered himself as having stood in a middle situation, a mediator between the two Parties. This is the substance of what fell from him. He was evidently much pleased and in high spirits. I also saw Tindal. He requested a day for consideration. He wishes, as the ultimate object of his ambition, the Common Pleas. I shall see him again tomorrow.

(Harewood MSS.)

\section{George Canning to Lord Lyndhurst.}

Chiswick. 26 July, II p.m.-The Chief Baron's is a most creditable letter. Give him a little time (as he wishes it) or take him at his word, as you think best. His retiring pension should be the first thing that he seals.

(Harewood MSS.)

\section{J. C. Herries to Charles Arbuthnot.}

$G^{t}$ Geo. St. 26 July. Confidential.-Thanks for your letter. I am very glad the interview took place between the Duke \& the King. The more the good feeling between them is maintained the greater will be the facility of setting things right again when the proper opportunity arrives. I am quite confident that the new friends cannot long continue so. Independently of all other considerations, the special imprudence $\&$ fiery tempers of some of the leaders must inevitably lead to a violent separation in due time. The possession of the Government during the remainder of the present reign, at least, by the Tories, will then depend upon the prudence of their management at that juncture.

I am pursuing the course which I long since told you I should adopt. I am getting out of my trammels; but using my best endeavors to do so without creating inconvenience or embarrassment to any one. I shall give every assistance in my power to prepare for the difficult arrangements which we have to make in the next session-upon the successful execution of which, the stability of the Govt, let who will be at the head of it, must materially depend.

Canning's health does not improve. He himself appears to despond more about it than he has ever done before. So, at least, Planta tells me. I am to see Knighton on Monday next. If anything occurs worth communicating I will write to you.

(Arbuthnot MSS.) 


\section{George Canning to Lord Lyndhurst.}

Chiswick. 27 July.-Tindal's note rather puzzles me. You are the best judge (I am none) whether the stipulation which he asks, of succession hereafter to the $\mathrm{C}$ [ommon] $\mathrm{P}$ [leas] be a reasonable one. If it be so, and if Tindal takes the place of Chief Baron only in transitu, it is obvious that $\mathrm{B}$ [rougham] by waiting that first turn, will be when that turn is over only where he would be now : with both Chief Justiceships filled up against him. Is it not possible that this consideration might alter B[rougham]'s view as to present acceptance? I presume Tindal would be satisfied to wait where he is for the C[ommon] P[leas]. Indeed, from the tone of his note, I should think he would prefer doing so. Now in that case the place of $\mathrm{C}$ [hief] $\mathrm{B}$ [aron], if not accepted by $\mathrm{B}$ [rougham], must be filled up by some other person-a new obstacle to his ultimate object, whatever that may be. Is it not at least worth while to bring this new state of the case under B[rougham]'s contemplation? Could not Tindal be made useful in doing so?

(Harewood MSS.)

\section{Lord Lyndhurst to George Canning.}

Friday [27 July].- . . . Tindal, whom I saw this morning, will, I am persuaded, do whatever we wish. I will see him again. Should you wish Tindal to decline the office of Chief Baron, I think the contingent promise of the Common Pleas coupled with the present possession of the Exchequer ought not to be made.

(Harewood MSS.)

\section{Charles Arbuthnot to Robert Peel.}

Friday, 27. July.-I send you a letter from Herries, and I beg you to forward it to the Duke when you have read it. . . . I dare say there is confusion in the enemy's camp. I wish Herries w not try to lessen their difficulties. Every one ought to take his line for or against. (Add. MS. 40340, f. I64.)

Ibid.-Lord Maryborough came to dine and sleep at S[trathfield] Saye on Wednesday. He had a long talk at night with the Duke, and it lasted so late that I did not hear much from the latter till the next morning. It is rather difficult to make out all that has taken 


\section{THE FORMATION OF CANNING'S MINISTRY 273}

place. Indeed, I am not quite sure that $\mathrm{L}^{\mathrm{d}}$ Maryborough tells all that he knows. The King certainly was most anxious to see the Duke. And Lady Conyngham joined in this anxiety-and Lord and Lady Maryborough did all they could to facilitate the meeting. But I had observed that Lord Maryborough when he came the first time to $S$. Saye was very shy of having his name mentioned; and this it was that caused me to state that I did not think the Duke $\mathrm{c}^{\mathrm{d}}$ go, unless $L^{d} M$. was willing to have it said that he had communicated by authority the King's surprise that, being in his neighbourhood, he had not called to see him; and unless this was recorded by the Duke as having been said to him by his brother. $\mathrm{L}^{\mathrm{d}} \mathrm{M}$. at first hesitated, and did not like his name to be mentioned. He at last consented after some reflection, and then the Duke wrote the letter to him $\mathrm{w}^{\text {ch }}$ fortunately is upon record. It now appears that the moment the Duke had left the Lodge the King wrote to apprise Canning of the visit, and said that he had come unexpectedly and unasked. It is unknown to us what was done by Canning when he heard of the visit. He wrote a letter-a sentence of $w^{\text {ch }}$ was read to Lady Maryborough-but this expressed no more than that he was glad the Duke had paid the unexpected visit to the King, and that he wished he had accepted his $\mathrm{M} \mathrm{y}^{\prime} \mathrm{s}$ offer. It is imagined that this must refer to the King's former offer, for no offer was made to the Duke the other day at Windsor. But Canning must have done and said more than this, for according to Lord Maryborough's account they are in the greatest state of alarm and uneasiness at the Lodge, and Lord Maryborough himself is greatly alarmed lest his name sh $^{d}$ be brought into notice. It seems clear that Canning has remonstrated and has let the King know that if there are communications with the Duke, men's minds will be unsettled and the Government weakened. At least this is to be inferred from Lady Conyngham's language, and from the manner in $\mathrm{w}^{\mathrm{ch}} \mathrm{L}^{\mathrm{d}}$ Maryborough is now understating what he had originally reported to have passed when the King first expressed anxiety to see the Duke. This understating by $\mathrm{L}^{\mathrm{d}}$ Maryborough was observed by the Duke as well as by me. It is clear to me that $L^{d} M$. is fearful lest Canning sh ${ }^{d}$ insist upon his dismissal. I think I have told you pretty accurately what we heard and what also we had a right to infer. The Duke is full of disgust and indignation. It is fortunate that he acted throughout with caution, and that he has a copy of the letter in $w^{\text {ch }}$ he told his brother that he shd go to Windsor in consequence of being apprised by him that the King was surprised at his not calling. I ought to tell you that from Lady Conyngham's 


\section{THE FORMATION OF CANNING'S MINISTRY}

language to Lady Maryborough ${ }^{1}$ there now is an attempt to get the Duke to resume the command unconditionally and without expecting an apology from Canning. (And I fear that $L^{d}$ Maryborough $w^{d}$ aid and abet in this scheme if he were able.) But the Duke has written a short and clear and very strong $\mathrm{mem}^{\mathrm{m}}$ (for Lord Maryborough), declaring once for all that he will not take the command until the Minister makes an apology as ample and as public as was the offence. (All therefore is as rightly done by the Duke as possible. I think he is more disgusted with the baseness of the Court than I ever saw him.

I hope you will comprehend me. I write in a gt hurry. I go to Woodford tomorrow.

[PS.] The Duke got $\mathrm{y}^{\mathrm{r}}$ letter yesterday before we came away.)

Lady Conyngham said that she hoped the Duke $w^{d}$ take the command immediately, for the new arrangement under Sir G. Murray was ready for signature, and if once carried into effect could not be got rid of. All this is humbug, but they now can less than ever have any influence with the Duke, as he perfectly loathes their shabby baseness. I see he is not over pleased with Lord Maryborough.

Pray send Herries's letter to the Duke at APSLEY House, and not to S. Saye. . . . (Ibid., ff. I60-3.)

\section{George Canning to Lord Lyndhurst.}

Dorening Street. 28 July.-What appears to me best is that $\mathrm{B}$ [rougham] should be invited to reconsider his decision, on T[indal]'s refusal to take the Exchequer without a promise of the Common Pleas hereafter, giving T[indal] the promise of C[ommon] P[leas], if he chooses to wait for it as Solicitor General. This affords the best chance of B[rougham]'s taking the Exchequer now, rather than on T[indal]'s promotion hereafter.

(Harewood MSS.)

\section{Robert Peel to Charles Arbuthnot.}

Whitehall. 3I July. Private.-I sent H[erries]'s letter to you to the Duke and burnt as you desired the separate note. I met the Duke yesterday and rode with him to Chelsea. He had heard

1 The following portion of the letter, as far as " shabby baseness", is in Parker's Peel, i. 492-3, except for the phrases which are enclosed in round brackets. 
nothing new. He dines with me today. Hobhouse's successor has been appointed-a $\mathrm{M}^{\mathbf{r}}$ Phillip[p]s who wrote a good book upon evidence. 1 He married I believe a sister of Charles Grant. The Saints are greatly pleased by his appointment.

I hear that Lord Lansdown is to have the patronage of Scotland. I doubt the correctness of Herries's as to the probability of collision. Both parties have so strong an interest in agreeing that each will make many sacrifices before they approach an absolute quarrel. . . . (Arbuthnot MSS.)

366. James Abercromby to the Earl of Carlisle.

Tuesday, 3I July.--Lady C[onyngham]'s note to the D. of D[evonshire] struck me as being very urgent--but not knowing her I could not appreciate its value, because that depends upon her sense \& sincerity. It was clear to me that the note could not be shewn to Canning, \& beyond that point my mind was not made up. What I most inclined to think was, that the Duke should report the substance to $\mathrm{M}^{\mathrm{rs}} \mathrm{C}$ [anning]. What passed at P. Leopold's has confirmed me in that opinion, only I think it most desirable that Lady Carlisle should be the medium of communication. The advantages of that are, that it conveys the fact most promptly to Canning-it makes it easy for the Duke to say that he has not communicated with Canning which, as things stand, seems desirable. The Duke was to write to $L^{y}$ C [onyngham] by the post of yesterday-she will probably reply, \& if that topic is resumed fresh light may be thrown upon it. It would be well therefore if $L^{y}$ Carlisle can ascertain without delay from the Duke what she says. I think that $L^{y}$ $\mathrm{C}$ [onyngham] in her own mind draws a distinct line between political power \& the command of the army, for she says the visit had nothing political in it. But then I think it is no less clear that she looks upon Wellington's return to the Horse $\mathrm{G}^{\mathrm{ds}}$ as a measure highly important, if not essential, to Canning's security. This looks like a serious qualification of Canning's influence with the King. If Wellington comes back will he be honest or will he be an intriguer-that is a formidable question for Canning. I incline to talk to $L^{d}$ Lansdowne: do you see any objection to my doing so ?

[PS.] Perhaps the best thing will be for you to speak to $L^{d}$ Lansdowne. It is very right for Canning to be conciliatory \&

1 Treatise on the Law of Evidence, London, 1814. 


\section{THE FORMATION OF CANNING'S MINISTRY}

prudent but I hope he won't be induced to bend too much or to write. That would lower us all. It must not be said that you exist only because Well[ington] has accepted the army.

(Castle Howard MSS.)

\section{Charles Arbuthnot to his son Charles.}

Woodford. I August._. . . I can tell you but little of politics. You see it is become quite a Whig Govt. The King gives his strongest support to Canning, \& while this is the case it will I think be difficult to remove him. But the King has not as yet taken at all to the Whigs, \& sh ${ }^{d}$ Canning's health entirely break down, or sh ${ }^{d}$ he $\&$ his new friends fall out, the Government must break to pieces I imagine. It will I dare say remain pretty much as it is till Parliament meets. In the meanwhile they are doing all they can to lower expences, \& I understand that the army is to be reduced 10,000 men. ...

(Arbuthnot MSS.)

\section{William Lamb to the Marquess of Lansdowne.}

Phoenix Park. 3 August.-The Chief Baron, as I am informed, intends to leave his Circuit in the middle and go to England for the purpose of negotiating the terms of his resignation. His demands will of course be high in consequence of the great bargain struck by Lord Norbury [No. 320].

... Lord Wellesley is exceedingly hurt and irritated with Canning for never communicating with him upon his becoming the head of the Government nor upon any subsequent step whatever. $\mathrm{He}$ was also grievously offended at the offer of Vienna, and sooth to say, considering their long friendship, he has not perhaps been very skilfully or delicately managed. However, I suppose Canning had so much to do that he could not think of him, or did not write because he did not know what to say to him. Lord Wellesley is of a very susceptible temperament, but with patience and observance anything may be done with him. $\mathrm{He}$ is become irresolute and indecisive, and is particularly very nervous with respect to the situation of the Government upon the Roman Catholic question. If he could be in any manner somewhat assured upon this point, it would be advantageous. . . . After all, as far as I can judge, his 


\section{THE FORMATION OF CANNING'S MINISTRY}

Government appears to me to be the only one that has ever done anything for this country. His encouragement of petty Sessions, for instance, and his detaching the appointment of the Assistant Barristers from all local and parliamentary interest have, I am assured, much improved the administration of justice, and with the improvement of the administration of justice a confidence in it has to a certain degree naturally grown up. I cannot but be apprehensive that much of this sort of good may be lost under a Lord Lieutenant who has not the same knowledge either of the principles or of the details of business of this nature. Lord Wellesley is decided against foreign employment and anxious for employment at home, but not for a place of labour. Though he would not admit it, I think he is in his own mind sensible that his habits disqualify him for such a situation.

(Bowood MSS.)

\section{James Abercromby to the Earl of Carlisle.}

Friday night [3 August]. Private.-I carried to Richmond the latest \& I grieve to say, the worst account of $M^{r}$ Canning. When I had an opportunity of talking with $\mathbf{L}^{\mathbf{d}} \mathbf{L}$ [ansdowne] I found him greatly shocked by the event which we anticipate. I endeavoured to urge with all the effect I could, the magnitude of the crisis \& the necessity of not deserting the public, so long as they were disposed to stand by a good cause. To all this he cordially assented \& I should say that he appeared as vigorous as one could wish a prudent man to be. I also talked very freely to Lady L[ansdowne] \& she is quite right in all respects. She feels that if we are dismissed $L^{d}$ $L$ [ansdowne] will be relieved from an arduous \& difficult position, but she is quite resolute in thinking that the greatest evil will be to shew any want of self confidence in such an emergency. She also seems, as I guess, to think that he will be more easily excited to exertion than I should have expected. On the whole I think I did good \& it is well that I had an opportunity of giving an early, if not the first impression.

If I recollect right it was Peel who went to communicate to the King the account of $L^{d}$ Liverpool's seizure, which looks as if it belonged to the Home Secretary to do so. This should be thought of in case of accidents. L[ansdowne] does not intend to be in town tomorrow unless it becomes necessary. I wrote a line to the D. of $\mathrm{D}[$ evonshire]. I begged him not to do any thing hastily \& to wait 


\section{THE FORMATION OF CANNING'S MINISTRY}

for the letter I should write tomorrow-but added that I thought he should not linger at Chatsworth unnecessarily.

[PS.] What do you think will be the feeling of Canning's friends $\&$ of $\mathrm{L}^{\mathrm{d}}$ Goderich - to attach themselves to the Whigs or to reunite with the Tories. I suppose that will depend on the disposition of the King.

(Castle Howard MSS.)

\section{J. C. Herries to Robert Peel.}

Montreal. Sunday, 5 August.-Your note did not reach my house until I had left it for this place, which will account for your not receiving an answer to your kind invitation. I receive very bad accounts of Canning today. When I was with him on Thursday he. was in bed and apparently excessively ill altho' those about him called him " better." It appears to me out of all probability that he can long struggle with the anxieties and difficulties of his present office, even if he gets the better of the present attack.

(Add. MS. 40394, ff. 166-7.)

\section{I. J. C. Herries to Robert Herries.}

Montreal. Sunday, 5 August-[Canning].- - . . It seems to me impossible that he can go on with such health, even if he should get over the present attack. What effect his death or resignation might have upon my fortunes I cannot even conjecture. I fear if it were to happen just now it would embarrass me exceedingly. ${ }^{1}$ You will be glad to learn that the rumours of my resignation have called forth from a great variety of quarters communications to me of good opinion \& goodwill which are highly gratifying. When such assurances are given to a retiring Secretary to the Treasury, they have the appearance of being sincere. ...

(Herries MSS.)

\section{Henry Unwin Addington ${ }^{2}$ to Stratford Canning.}

London. 9 August. Private.- . . You may possibly be surprised at my taking this painful occurrence so much to heart; but,

${ }^{1} \mathrm{He}$ was on the point of leaving England for a two months' continental holiday.

2 Lord Sidmouth's nephew. He was Chargé d'Affaires at Washington, $1823-5$. 


\section{$\begin{array}{ll}\text { THE FORMATION OF CANNING'S MINISTRY } & 279\end{array}$}

although till lately but little, or rather not at all, known to $\mathbf{M}^{\mathbf{r}}$ Canning, he had treated me with such kindness, and had, since my return from America, shewn himself so invariably just, and friendly and liberal towards me, that there were few men towards whom I had a stronger attachment or a livelier feeling of gratitude than towards my departed chief. . . .

About ten days before Mr Canning's death I had dined at Chiswick with him quite en petit comité, that is, with Gallatin, C. Grant (my new colleague) and Backhouse ; and at that time I was painfully struck with a ghastliness of feature, and dejection of air in my kind protector, which I had never before observed. I urged him to give up business, if possible, for a time, and follow Huskisson's example in taking a complete holiday. He told me he could not at that time, but added cheerfully, and rather playfully, that he hoped to get a comfortable respite from toil in September. I left him with a vague sense of apprehension, but not having the least presentiment of the appalling suddenness, and the visitation which fell upon him so shortly after.

It was Portugal that killed him, or rather, it was the double office of Premier, and, still, Foreign Secretary (too much even for a Hercules in mind and body) which, in his debilitated state on his accession to the former, overwhelmed and crushed him.

The Monday week before he died, he had been to Windsor on Portuguese affairs, when the King was struck by his altered appearance, and, I believe, desired Knighton to call upon him and question him about his health, which Knighton did next day; but unfortunately Mr Canning was then occupied in drawing up a Minute for the Cabinet on Portuguese affairs, and, I am told by those who have seen it, a most masterly one. He therefore merely informed Knighton that he had not felt well for a long time, and was then anything but better. He could not speak to him at that moment however on that subject, but begged he would call again before he returned to Windsor. This Knighton did on the Thursday morning, I believe, and on again questioning $\mathrm{M}^{\mathbf{r}} \mathrm{C}$. more closely he found that his liver and pleura were evidently at that moment in a state of high inflammation. Measures for subduing it were instantly resorted to, but it was too late. The constitution was too much enfeebled to bear sufficient depletion for attaining that end. The inflammation gradually spread and was attended with horrible agony. For four days before his death $\mathrm{Mr}$ Canning had been in a most singular state of half-wandering of mind. Every thought was evidently turned to 


\section{THE FORMATION OF CANNING'S MINISTRY}

one subject and that a public one (Portugal) and he was incessantly dictating to Stapleton something that shewed perfect clearness of conception in the mind, but inability of the physical powers to produce it in that shape. It was accordingly a singular mixture of method and incoherency. At times, however, when he rallied a little, he talked with perfect sense and great correctness, when the tortures he endured were suspended for a while. Down to the last hour of his existence he appeared to be arguing some point of public interest, and endeavouring to persuade some invisible auditor of the justness of his own impressions. Until very lately, even if then, he had not suspected the imminence of his danger, or rather the ardour of his own mind, not the desire of living, had refused to abandon the hope of recovery. I am convinced that the ungenerous and unmitigated malignity of hostility which had pursued him ever since his accession to the Premiership had pressed painfully upon his feelings ; for, since a fortnight after that event, I have never seen him with an open or a cheerful brow.

... You will easily understand how sensibly I must feel this afflicting stroke on every account; most I can truly say, from motives of personal grief : but also from those of personal interest in a certain degree : for $\mathrm{M}^{\mathrm{r}}$ Canning liked me and thought well of me (I am speaking to an old friend, and therefore without either vanity or affectation) and would, I am sure, have pushed my fortunes. I am now once more " on the bleak strand alone." Thanks to his friendship however in placing me in the charge, in part, of difficult negotiations, I am more known than I was, and have more title to claim consideration from others, although personally a stranger to them .....

God bless you! and believe me ever your affe friend. (P.R.O., F.O. 352/16.) 